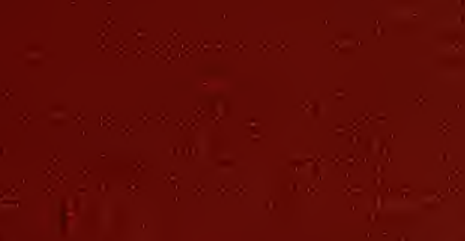




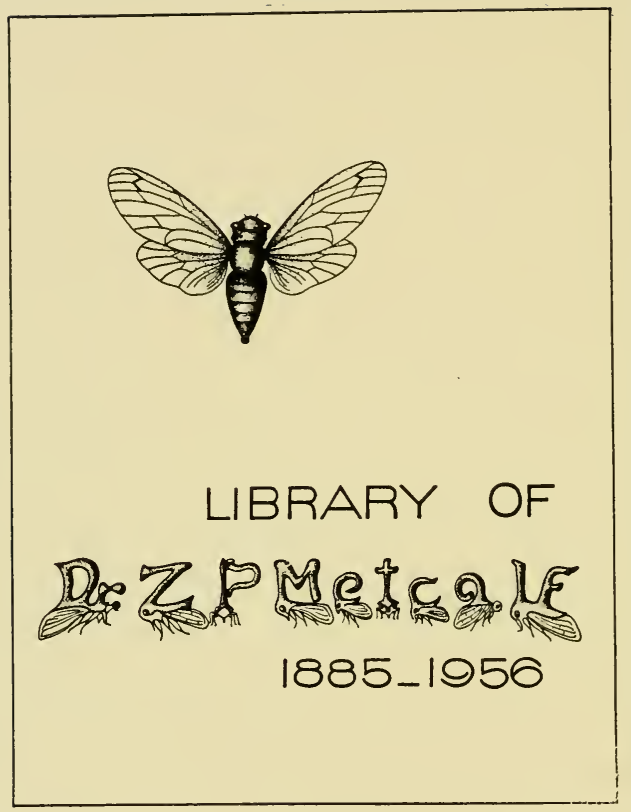







\title{
HOMOPTERA INDICA.
}

\author{
Cinankale \\ trom
}

E. T. ATKINSON, B.A. : B.C.S.

\section{CALCUTTA.}

1884-86. 

In compliance with current copyright law, the Etherington Conservation Center produced this replacement volume on paper that meets ANSI Standard Z39.48-1992R (1997) to replace the irreparably deteriorated original.

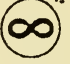

2002 

The papers included in this volume have appeared in the Journal of the Asiatic Society of Bengal. The first in Part II for 1884, the second, third and fourth in the Volume for 1885, and the remainder in the Volume for 1886. In $1865 \mathrm{I}$ was present at a meeting, the object of which was to place the study of our Indian fauna on a better footing. and to enlist the aid of all who cared for the subject in some organised scheme. After some discussion, it was resolved to divide the work amongst those who were then able to render assistance, so as to arrive at some definitive result within a reasonable time. Dr. Jerdon's works on the Mammals and Birds of India were near completion, and I undertook the Lepidoptera, and subsequently the compilation of a list of the Insecta which should roughly indicate the state of our knowledge and at least give references to books which would enable the student to know where he should go to when taking up an order. This proved to be a long and troublesome labour, for working in the country, I had either to buy or borrow the works of reference and often had to wait a year for one that was essential. The list was completed in 1880 and published in 1882. Lepidoptera in the meantime had fallen into good hands, Messrs. Moore, Distant, Marshall and De Nicéville; there were specialists available for Coleoptera and Hymenoptera, Mr. Wood.Mason was engaged on Orthoptera and I took up the Rhynchota. The present volume is the result of an attempt to lay the foundation of an 'Homoptera INDICA' and to clear up the really forbidding synonymy of this group and make its study easier to those who care to undertake it. I soon found that to offer references only to works which are practically unprocurable in India could be of no possible nse to the class for whom these papers are intended, and could not reasonably be expected to subserve in the slightest degree the object in view, that is to enlist the labours of intelligent and competent observers in this exceedingly interesting investigation. I have therefore given so far as I can the original descriptions, however vague, leaving to a second edition when a sufficient number of each species is before me, the correct and full description which is so desirable. It would only lead to confusion were I to attempt to redescribe most of the species now enumerated without seeing the types. Our first work now is to collect and note carefully time and place of appearance and anything regarding the lifehistory that can be procnred, and I have little doubt that in a few years 
we shall have some tangible results. Mr. Distant has kindly consented to work up our Cicadide, and in time I hope that others will take up other sections. The Homoptera make a very poor show in the Indian Museum, and require early and earnest attention. The Hemiptera are much better worked and are better represented whilst the Phytop?.thires have not a single specimen to represent them. Some effort is now being made to collect the scale-insects (Coccida) which are of great economic importance. The Lecunium coffece and nigrum that attack the coffee-trees and the white mealy scale (Dactylopius adonidum) which is such a pest in Ceylon belong to this group; also the Carteria lacca from which is produced the lac and lac-dye of commerce.

E. T. ATKINSON.

\section{Park Street,}

Calcutta.

18 th MFay 1886. 


\section{NOTES}

\section{INDIAN RIIYNCIIOTA,}

No. 1.

BY

E. T. ATKINSON, B. A.

[Reprinted fiom the Journal of the Asiatic Society, Bengal, Vol. LIII, Part II, No. 3, 1884.]

CALCUTTA :

PRINTED BY J. W. THOMAS, BAPTIST MISSION PRESS. 1885. 


\section{NOTES ON INDIAN RIIYNCHO'TA.}

Unless where expressly stated to be descriptions, the notes attacherl to each species are nerely intended as aids to identification; and the measurements of specimens not in the Indian Muscum lave been converted into millimetres from the measurements of the several authors.

\section{HOMOPTERA.}

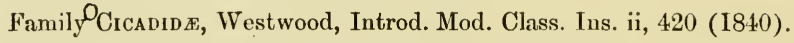

O Stridulantia, Stål, Hem. Afric. iv, p. 1 (1866).

Ocelli three, placed ou the dise of the vertex. Pronotum and mesonotum very large. Anterior coxæ prismatic, oblong, inserted in the anterior angles of the prostethium : intermediate and posterior coxre briefly subconical, somewhat contiguons, remote from the sides of the body. Anterior femora incrassated, very often spinose, tibix smooth. Tarsi 2-3 jointed. Abdomen in the males with an organ of sound on each side at the basc. 


\section{oGenus Polyneura, Westwood.}

Westwood, Arc. Ent. i, p. 92 (1842): Am. et Serv., Hist. Nat. Hém. p. 460 (1843) : Stål, llen Afric. iv, p. 3 (1866).

\section{Ol. Polyneura ducalis.}

Polyneura ducalis, Westwood, Arc. Ent. i, p. 92, t. 24, f. 2 (1842); Jardine, Nat. Lib. t. 18, f. 1 (18.13); Am. et Serv., Hist. Nat. Ins. Hém. p. 460 (18.13); Walker, List. Hom. B. M., i, p. 2 (1850).

Easily recognised by its rich golden brown colour and the apical half of the tegmina being finely reticulated with hexagonal cells. Body long 35 ; exp. teg. 102 millims.

Reported from Assam, Sikkim, Nepál. The Indian Museum possesses specimens from Sikkim and Assam.

\section{OGenus Pecilopalitia, Stål.}

Hem. Afric, iv, p. 2, (1866) ; Berl. Ent. Zeitschr. p. 168 (1866).

Allied to Otettigades, Am. et Serv. Thorax angulated on each side, anterior femora not spinose, metasternum elevated, the elevated part sulcate, prodnced and subsinuato-truncated in front.

2. Pécilopsaltria affinis.

O Tettigonia affinis, Fabr., Syst. Rhyn. p. 37 (1803).

C'Cicula afjinis, Germar in Thon's Arehiv. Ent. ii, fasc. 2, p. 1, 6, (1830); in Silbermanı's liev. Ent. ii, p. 79 (1834); Walker, List Hom. B. M. i, p. 3 (1850).

Pacilopsaltria affinis, Stål, Hem. Fabric. ii, p. 4 (1869).

Body long 23 ; exp. teg. 77 millims.

Reported from India, but no specimens appear in the British Museum list, and it wonld be well again to identify the locality of the specimen noted in Mus. Lund.

\section{Genus Pratypleura, Amyot \& Serville.}

Amyot et Serville, Hist. Nat. Ins. Hém. p. 465 (1843) : Stål, Hem. Afric. iv, p. 2 (1866) : Butler, Cist. Ent. i, p. 184 (1874).

(a.) Species with yellow or tawny wings.

L'3. Platypleura phalenoides.

Platypleura phalanoides, Walker, List Hom. B. M. i, p. 4 (1850) : Butler, Cist. Ent. p. 185 (1874).

C. Platypleura interna, Walker, 1. c. iv, p. 1119 (1852), which differs in having the anal angle only (instead of the whole flap) of the wings black.

i. Platypleura congrex, Stål, MS., is also possibly only a variety of this species.

Reported from Bengal, Assam, Silhat, N. India. A somewhat common species in Sikkim. The Indian Museum possesses specimens from Sibságar, Sikkim, and Darjiling. 
An examination of some fifty males slows some variations in individuals, even amongst those collected in the same locality. In the hyaline apical portion of the tegmina, the brown band is sometimes eonnected with the marginal row of spots, sometimes with the brown band across the middle part of the tegmina, and sometimes with neither. The Ityaline spots in the radial and $3-4$ ulnar areas vary much in size, and the metathoracic markings vary in size and distinctness. The venation, too, is not altogether uniform, and the colour of the thorax varies from green to brown.

ㅇ. Body sordidly luteons above and below. Face moderately conrex, transversely sulcated, with a longitudinal groove, luteous, vertex and pronotum furrowed, luteous. The mesonotal mirks are represented by two almost obsolete slort black lines on fore borker and two faint black dots on hinder border. Abclomen black above, first three segments marginally luteous-pubeseent; below, central portion tawny, thickly pubescent. Opereula small, somewhat rounded, wide apart. Legs eoneolorous with body: posterior tibiæ spinose, tarsi and claws pieeous. Tegmina, markings as in $\delta$, but basal half suffused with deep fulvous. IVings as in $\delta$, but apical third alone brown, limbus hyaline, flaps fulvons. Lengtl body, $22 \frac{1}{2}$; exp. tegm. 75 ; of one tegmen 34 ; breadtl of pronotum 13 millims.

HAB. Sikkim, one specimen only in the Indian Musenm.

\section{4. Platypleura assamensis, n. sp.}

Sordid green, face very slightly convex, transversely sulcated, with a longitudinal groove : a fascia extending from eye to eye through the base of the antennr, black. Rostrum extends to third ablominal segment, tip piceous. Markings above as inOP. phalcenoiles, IValker. Abdomen piceous, eacl abdominal segment with a slight marginal fulvous pubescence. Opercula very small, wide apart piceous in the $q$; elose together, piceous and margined with slight tawny in the $\delta$. Basal half of tegmina, brown, with irregular pale markings : a hyaline spot in the third quarter of the radial area, a pale spot at the base of the radial area and the $4-5$ ulnar areas. Apical half of the tegmina pale hyaline; a brown patch extending throngh the apical anastomoses of the $1-3$ ulnar areas : an inner apical row of six brown spots, first two and last broadest, first two confluent, middle sagittate, last confluent with the dot on the limbus: apical veins ending in six small oblong brown spots, beyond which in the limbus are six minute dots. Wings marked as in

$\checkmark P$. phalcenoides with which it is closely allied, but the body is much less robust, and smaller; and there is a difference in the markings and colour of the tegmina. Length body, $23 \frac{1}{2}$; exp. tegm., 69 ; of single tegmen, 30 ; breadth of the pronotum 12 , millims. 
$\delta$ is slightly smaller, tegmen, 27 millims.

Hab. Sibságar and Nága Hills : $\delta$ and $\Varangle$ in Indian Muscum.

\section{O5. Platypleura nicobarica, n. sp.}

Light ochraceons, shining. Face moderately convex, transversely sulcated, with a median longitudinal groove, an interrupted fascia extending from eye to eye, and a patch on each side of the base of the rostrum and along the first joint thereof, black. The rostrum extends well beyond the posterior coxæ, tip black. Eyes dull castaneous, pilose behind. Vertex deeply grooved; the hollows, a small triangular patch below the ocelli, a narrow fascia from eye to eye through the ocelli; and a narrow short longitndinal line between the ocelli and eyes, black. Pronotum furrowed, with a single, longitudinal, narrow, short, black linẹ in the middle of the anterior margin, lateral processes subtriangular and their external margins brown. The mesonotum with two triangular, black spots, their bases resting on the anterior margin, and on each side a large distinct V-shapel mark, slightly interrupted on the inner side, and two small round spots near the posterior margin. Segments of abdomen black, margined with yellow, above and below, slightly pubescent. Legs ochraceous, extremities of tibiæ and claws brown-black, posterior tibiæ spinose. Opereula ochraceous, small, rounded, contignous, having a black patch near the base of posterior coxæ. Tegmina, basal half tawny with irregular brown markings in the radial and 1-4 ulnar areas and one in the costal membrane. The upper third of the third ulnar area and the apical areas hyaline, with an almost obsolete series of minute clots at the end of each vein : wings ochraceous, apical third brown, with veins ochraceous, a discal streak to anal angle and two lines confluent at the inner angle, brown. Length body, 24: exp. tegmina, $75 \frac{1}{2}$ of single tegmen 33 : breadth of the pronotum, $14 \frac{1}{2}$ millims.

$\mathrm{H}_{\mathrm{AB}}$. Nicobar Islands : in Indian Museum.

\section{6. Platypleura sphinx.}

Platypleura sphinx, Walker, List. Hom. B. Mr. i, p. 13 (1850): Butler, Cist. Ent. p. 188 (187t).

Tegmina whitish, brownish-tawny towards the base and having elsewhere some irregular pale-brown marks which here and there include white spots. Body long 18; exp. teg. 43 millims.

Reported from N. Bengal, N. India.

\section{Platypleura celebs.}

Platypleura cęlebs, Stål, Trans. Ent. Soc. 3rd Ser. i, p. 573 (1863): Butler, Cist. Ent. p. 188 (1874). 
Allied to Orceilopsaltria capitata, Olivier, (Enc. Méth. v, p. 754) in regard to size, broadness of apical limbus, tegmina and wings. Body long 23 : exp. teg. 68 millims. Reported from N. India.

\section{O8. Platy Pledra Andamana.
Platypleura andamana, Distant, Trans. Ent. Soc. p. 174 (1878).}

This species was described from a specimen procured from the Andaman islands. Body long 22 : exp. teg. 84 millims.

\section{O 9. Platy Pleura roepstorffit, n. $\mathrm{sp}$.}

8. . Brownish tawny. Face gamboge colour, moderately convex, transversely sulcated, with a brown longitudinal groove. Rostrum extending almost to the posterior margin of the first abdominal segment, tip brown. Legs brown above, tawny below; tibix setose, posterior pair spinose. Eyes bright eastaneous, moderately prominent, pilose behind. Second joint of antenna pale tawny. A fascia from eye to eye, through the base of the antennæ and frons, and another throngh the ocelli, black. Pronotum grooved, with an obtuse-angled black mark on middle of posterior border; lateral processes subtriangular, anterior margin slightly brown. Mesonotum with two obconical spots extending backwards from anterior border and having between them a variable sagittate mark, two dots wide apart, near posterior border, and a very obscure mark situate on the outer side of each of the obconical spots, black. Abdominal sutures black, margined with luteous, pubescent; anal segment below, luteous. Opercula very small, subelliptical, wide apart in the $\delta$; contiguous, semi-rounded, in the $q$. Tegmina brown, opaque: basal third tinged with tawny, very apparent when stretehed out; two spots in the radial area (the basal extending into the costal membrane) and one in the fourth ulnar area, black. A patch in the middle of the first ulnar area, extending into the third, and one near the base of the third ulnar area, extending into the fourth, pale brown. Apical area pale brown; veins adorned with oval marks, brown, with a centre of pale brown. External margin with a row of six subquadrangular brown spots, divided by oval pale brown spots. Wings fulvous tawny, disc and a band along the fore

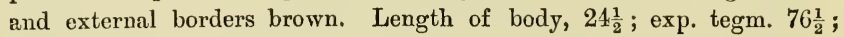
of one tegmen, 34 ; breadth of pronotum, 12 millims.

Closely allied tDP. andamana, Distant.

HAB. Andaman Islands. Several specimens are in the Indian $\mathrm{Mu}-$ seum.

\section{(b.) With black and white wings. \\ O10. Platypleura basialba.}

Doxypleura basialba, Walker, List Hom. B. M. i, p. 26, (1850).

Platypleura basialba, Butler, Cist. Ent. i, p. 191 (1874).

Body long 19, exp. teg. 61 millims. Reported from N. Bengal. 


\section{Platypleura nobilis.}

OCicada nobilis, Germar in Thon's Arohiv. ii, fasc. 2, p. 9 (1830); in Silbermann's Rev. Ent. ii, pt. 2, p. 82, (1834).

$\checkmark$ Cicada hemiptera, Guérin, Voyage Bélanger Ind. Orient. p. 500 (1834).

o Platyplenra semilucida, Walker, List Hom. B. M. i. p. 20 (1850).

Platypleura nobilis, Butlor, Cist. Ent. i, p. 121 (1874) ; Distant, J. A. S. B. xlviii, (2), p. 38 (1879).

Reported from Java, Singapore, and Tenasserim : there is a speeimen in the Intian Museum from Tenasserim. As this is a typical speeies of the smaller members of this genus, I re-describe it, the original deseription being praetically unobtainable.

Tawny. Face tawny, moderately convex, transversely suleated with the furrows brown and a longitudinal groove broadly black. Rostrum extending to the fourth abdominal segment, tip pieeous. Eyes dull castaneons, with a narrow black faseia, extending from anterior margin around the base of the antenna. Vertex with a bright tawny fascia on anterior margin and tivo minute obeonieal blaek marks, extending from posterior margin on each side of the oeelli, obsolete in some. Pronotum tawny, furrowed, furrows black; a line from the middle of the anterior border to the posterior border, black and quadrangularly expanded on the dise. Mesonotum fulvous brown, with two moderate obeonical black spots, extending backward from the fore border, midway between which there is a diseal line conneeted with a fascia on the hinder border also blaek. On the outer side of both the moderate obconical spots is a large obeonieal patch, black, and extending from the fore border almost to the hind border. The metanotum is bright tawny. The abdominal sutures are black, edged with fulvons, slightly pubeseent. Below, the fulvous margins of the abdominal segments alone appear. Operenla tawny, brown at the base, rounded, small, wide apart. Legs tawny, anterior and middle femora spotted brown, posterior tibio spinose. 'T'eg. mina, basal third tawny, with some irregnlar lighter markings : a hyaline spot, at the apex of the radial area, just above a dark brown spot which extends into the eostal membrane: a black spot in the ulnar space. Apical two-thirds of tegmina hyaline, with three minute brown spots on the apical anastomoses of the first and second ulnar areas, also a very minute brown spot on eaeh side of the middle of the vein separating the seeond from the third apical area and the third from the fourth; six minute brown spots on the limbus. Basal two-thirds of the wings brown, with a discal streak extending to the anal angle, tawny; apieal third, hyaline; flaps tawny with a brown line on the suture. Length body 16 ; exp. teg. 46 ; lengtlı of one tegmen 24 ; breadth of pronotum 8 millims. 
OVariety, a.-Markings on face and pronotum more distinctly black. The markings on the basal third of the tegmina are more distinetly pale forming a band of five spots extending from the costal membrane through the ulnar areas. The brown spots in the hyaline apical portion broader, the internal apical row produced through the apical areas and the exterual apical row of dots duplicated. 'The tawny discal streak of the wings wanting, flaps grey lyyaline. From Munipur, in Indian Museum. Allied toolatypleura insignis, Distant.

\section{Platypleura insignis.}

Platypleura insignis, Distant, J. A. S. B. xlviii (2), p. 39, t. 2, f., 2 (1879).

Allied to the preceding, but tegmina and wings very distinct, the opaque portion being much less than in that species. Body long 15; exp. teg. 45 millims. Reported from Tenasserim and Hindustan : a specimon from the former locality is in tho Indian Museum.

\section{(c.) With black, white, and red wings. \\ $0_{13 .}$ Piatypleura octoguttata.}

OTettigonia octoguttata, Fahricius, Ent. Syst. Suppl. p. 515 (1798); Syst. Rhyng. p. 39 (1803); Coquebert, Ill. Ins. i, p. 34, t. 9, f., 1 (1790).

Oxypleura sanguiflua, Walker, List Hom. B. M. i., p. 24 (1850) ; Ins. Sannd. Hom. p. 2 (1858).

O Pecilopsaltria octoguttata, Stål, Berl. Ent. Zeitsclır. x, p. 168 (1866) (re-described).

Platypleura octoguttata, Butler, Cist. Ent. i, p. 192 (1874).

Body long 27 : exp. teg. 80 millims. Reported from the Panjab, N. India, N. Bengal, S. India. The Indian Museum possesses specimens from Bengal, Calcutta, and Samblialpur in the Central Provinces.

\section{Plattpleura subrufa.}

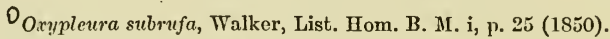

O Pacilopsaltria capitata, Stål, Berl. Ent. Zeitschr. x, p. 169 (1866), who joins together 'subrufa' and 'capitata' Olivier (Enc. Méth. $\nabla$, p. 75t, t. 112, f. 10), the former an Indian and the latter a Ceylon species. They havo boen separated again by Butler (Cist. Ent. i, p. 192) and should remain separate.

Platypleura subrufa, Butler, Cist. Ent. i, p. 192 (1874).

Body long 27 : exp. teg. 75 millims. Reported from Coromandel and India.

\section{(d.) With black, white, and brown wings.}

015. Platypleura bufo.

Doxypleura bufo, Walker, List Hom. B. M. i. p. 27 (1850).

Platypleura bufo, Butler, Cist. Ent. i, p. 195 (1874).

Body long 25 : exp. teg. 81 millims. Reported from India. 


\section{O 16. Platypleura cervina.}

Platypleura cervina, Walkor, List Hom. B. M. i, p. 16 (1850) 9 ; Butlor, C st Ent. i, p. 198 (187t).

OPlatypleura straminca, Walker, 1. c. p. 17, ฮ.

Body long 17 : exp. teg. 50 millims. Reported from N. Bengal.

OGenus Tacda, Amyot \& Sorvillo.

Am. \& Serv., Hist. Nat. Ins. Hém., p. 461 (1813) : Stâl, Hom. Afric. iv, p. 3. (1866).

\section{O 17. TACUA SPECIOSA.}

OTettigonia speciosa, Illiger in Wied. Zool. Arch. ii, 145, t. 2; Fabricius, Syst. Rliyn. p. 33 (1803).

C Cicuda indica, Donovan, Ins. Ind. Ilem., t. 2, f. 3, (1800).

O Cicada speciosa, Blanchard, Hist. Nat. Ins. iii, 165; Hém. t. 9 (1810-41).

Tacua speciosa, Am. et Serv., Hist. Nat. Ins. Hém. p. 462 (18+3); Walker, List. IIom. B. M. i, p. 46 (1850). J. A. S. Zool. i. p. 141 (1857).

Body long 55 millims. Reported from Java, Bengal (Donovan).

OGenus Tosena, Amyot \& Serville. (1S66).

Am. \& Serv., Hist. Nat. Ins. Hém. p. 462 (1843) : Stål, Ilem. Afric. iv. p. 3.

O18. Tosena melanoptera.

$\bigcup$ Tosena molanoptera, IVhite, A. \& M.N.H. xvii,p. 331 (181.6); Walker, List Hom. B. II. i, p. 46 (1850).

Body long 60 : exp. teg. 142 millims. Reported from Silhat, N. India. The Indian Museum possesses specimens from Sibságar and Sikkim.

19. Tosena mearesiana.

${ }^{0}$ Cicada mearesiana, Westwood, Are. Ent. i, p. 98, t. 25, f. 1 (1842).

Tosena mearesiana, Am. \& Serv., Hist. Nat. Ins. Hóm. p. 463 (1813); Walker, List Ilom. B. M. i, p. 40 (1850).

Body long 44 : exp. teg. 130 millins. Reported from N. India. The Indian MIuseum possesses specimens from Sikkim.

0 20. Tosena albata.

Tosena albata, Distant, Trans. Ent. Soc. Lond. 1878, p. 175.

Body long 59 : exp. teg. 132 millims. Reported from N. India.

0 21. Tosena splendida.

Tosena splendida, Distant, Ent. Month. Mag. xv, p. 76 (1878).

§. Body long 47 : exp. teg. 124 millims. 9. Body long 49 ; exp. teg. 127. Reported from Assam, Nága Hills, Khasiya Hills. The Indian Museum possesses $\sigma$ and 9 from the Lushai country. 
Genus Huecnys, Amyot \& Serville.

Am. \& Serv., Hist. Nat. Ins. Hém. p. 464 (1843) : Stål, Hem. Afric. iv, p. 4 (1S66).

\section{Huechis philemata.}

OTettigonia philcmata, Fabricins, Syst. Rhyn. p. 42 (1803); Stoll, Cig. p. 53, t. 13, f. 62 (1788).

O Cicada philcemata, Germar in Thon's Archiv. ii, fasc. 2, p. 26 (1830) ; in Silbermann's Rev. Ent. ii, p. 75, n. 52 (1834); Burmeister, Handb. Ent. ii, (i) p. 180 (1835).

OCicada sanguinea, Guérin, Voyage La Favorite, v, p. 155 (1839); Mlag. Zool. p. 75 (1839).

Huechys philemata, Am. \& Serv., Hist. Nat. Ins. Пém. p. 465 (18+3); Walker, List Hom. B. M. i. p. 251 (1850).

Guérin (l. c.) unites this species with the following and keeps oII. sanguinolenta, Fabr., which ho had not secn, distinct, but ho is not followed in this arrangement by later writers.

Body above black with the frons, two quadrato patches on mesothorax, and abdomen sanguineous: tegmina brown, wings cindery-grey and subliyaline. Body long 22 millims.

Reported from Philippine Islands, N. Bengal, and Sillat. Tho Indian Museum possesses specimens from the Nága Hills, N. India, and Tenasserim.

\section{Huechis sanguinea.}

$\checkmark$ Cicada sanguinea, De Géer, Ins. iii, 221, t. 33, f. 17 (1773); Gmclin Ed. Syst. Nat. i, 3, 2098 (1782); Westwood in Donovan's Ins. China, t. 16, f. 1 (1842).

O Tettigonia sanguinolenta, Fabricius, Syst. Ent. p. 681 (1775); Spec. Ins. ii, p. 321 (1781) ; Mant. Ins. ii, p. 267 (1787) ; Ent. Syst. iv, p. 25 (1794) ; Syst. Rhyn. p. 42 (1803).

OCicada sanguinolenta, Olivier, Enc. Méth. $\nabla$, p. 756 (1790); Germar in Thon's Archiv, ii, fasc. 2, p. 3 (1830), in Silbermann's Rev. Ent. ii, p. 75 (1834) ; Blanelard, Ilist. Nat. Ins. iii, p. 165 (1840-41); Guérin, Voyage La Favorite, v, p, 155, t. 45, f. 1 (1839) ; Mag. Zool. p. 76, t. 237, f. 1 (1839).

Huechys sanguinea, Am. \& Serv., Hist. Nat. Ins. Hém. p. 465 (1843); Walker, List Hom. B. M. i, p. 251 (1850) ; J. L. S. Zool. i, p. 84 (1856) ; ibid., x, p. 95 (1867) : Distant, J. A. S. B. xlviii, (2) p. 38 (1879).

Guérin separates 'sanguinolenta, Fabricius' and unites 'philœmata' with 'sanguinea'. OH. incarnata, Germar, Silb. Rev. Ent. ii, p. 75, (1834), and Brullé Hist. Nat. Ins: Hém. ii, t.' 3 . f. 2 , is probably only a varicty of $H$. sanguinea.

Head, thorax, and feet black: frons, two great spots on the mesothorax, and abdomen sanguineous : tegmina black: wings fuscous. Body long 18 ; exp. teg. $41 \frac{1}{2}$ millims.

Reported from India, Singapore, China, and the Eastern Archipelago. Specimens exist in the Indian Museum from Sikkim, Silsaigar, Calentta, and Tenasserim. 


\section{O24. Huecilys testacea.}

O Tettiyonia testacea, Fabricins, Mant. Ins. ii p. 267 (1787) ; Ent. Syst. iv, p. 24 (1794) ; Syst. Rhyn. p. 42 (1803) : Stoll, Cig. p. 41, t. 8, f. 41 (1788).

O Ciculu testacea, Gmelin Ed. Syst. Nat. i, pt. 4, p. 2098 (1782); Olivier, Enc. Méth. v, p. 756 , t. 113, f. 5 (1790); Germar in Thon's Archiv. ii, fasc. 2, p. 3 , (1830); (iuérin, Voyago La Favorite, v, p. 155 (1839); Mag. Zool. p. 78 (1839).

Inechys testacea, Walker, List IFom. B. M. i, p. 252 (1850).

The upper surface of the body without red marks : tegmina brown, only partly transparent: wings concolorous, veins black: abdomen sanguineous.

Reported from Coromandel.

\section{o 25. Huechis phænicura.}

O Cicada phonicura, Germar in Silbermann's Rev. Ent. ii, p. 76 (1834); Gnérin, Icon. du Lìgno Animal, p. 78 (1830-34).

IIuechys phenicura, Walker, List Hom. B. M. i, p. 252 (1850).

Black, entire frons, mesothorax, and abdomen sanguineous; tegmina and wings black; sometimes frons black in the middle and thorax witl a black basal spot or band running through it, sides and small median spot. red.

Reported from India, Sikkim.

\section{O 26. Huechys transtersa.}

Huechys transversa, Walker, List Hom. B. M. Suppt. p. 40 (1858).

Black: tegmina with costa and transverse veins red and a testaceous band. Body long 23 : exp. teg. 62 millims.

Reported from Hindustan.

\section{O 27. Huechiss thoracica.}

Hnechys thoracia, Distant, J. A. S. B. xlviii, (2), p. 39, t. II, f. 3 (1879).

Known by the red hour-glass-shaped fascia on pronotum. Body long 19: exp. teg. 43 millims.

Reported from Tenasserim and Hindustan.

\section{o 28. Huechys trabeata.}

UCicada trabeata, Germar in Thon's Archiv, ii, fasc. 2, p. 3 (1830) : Guérin, Mag. Zool. p. 78 (1839).

Huechys trabeata, Walker, List IIom. B. M. i, p. 252 (1850).

Body ferruginous, tegmina and wings fuscous with ferruginous veins.

Body long, $20 \frac{1}{2}$ millims ; tegmina broken at the ends.

Reported from Java.

There is a specimen in the Indian Museum, locality unknown. 


\section{OGenus Scieroptrar, Stâl.}

Ilem. Afrio. iv, p. 4. (1866).

Allied toOGacana : ulnar veins contiguons at the base or united for a short distance; head searcely narrower than the base of the thorax; anterior femora incrassated, spinose beneatl.

\section{O 29 . Scieroptera crocea.}

OCicala crocea, Gnérin in Voyage La Favorite, v, p. 159, t. 45, f. 3 (1829); Mng. Zool. p. 79, cl. ix, t. 237, f. 3 (1839); in Voyago La Coquille, Zool. ii (2), p. 182 (1830).

O Huechys crocea, Walker, List Hom. B. M. i, p. 252 (1850).

Scieroptera crocea, Stål, Berl. Ent. Zeitschr. x, p. 169 (1866).

Yellow: thorax above with four reddlish brown spots: ablomen saffron-red, more obsolete below. Feet yellow, tibio and tarsi black. Tegmina and wings liyaline with yellow veins.

Reported from Bengal.

\section{- 30 . Scieroptera splendidula.}

OTettigonia splendidula, Fabricius, Syst. Ent. p. 681 (1774); Spec. Ins. ii, p. 321 (1781) ; Mant. Ins. ii, p. 267 (1787); Ent. Syst. iv, p. 25 (1794); Syst. Rhyn. p. 42 (1803).

OCicada splendidula, Gmelin Ed. Syst. Nat. i, pt. 4, p. 2098 (17S2) : Olivier, Enc. Méth., v, p. 756 (1790) : Germar in Thon's Archiv, ii, fasc. 2, p. 45 (1830) : Guérin, in Voyage La Favorite, v, p. 159 (1839) ; Mag. Zool. p. 79 (1839) : Westwood in Donovan's Inseets China, t. 16, f. 4 (1842).

OInechys splendidula, Walker, List IIom. B. M. i, p. 252 (1850).

Scieroptera splendiclula, Stål, Borl. Ent. Zeitschr. x, p. 169 (1866) : Distant, J. A. S. B. xlviii (2), p. 38 (1879).

Yellow; thorax above with four large blackish rounded spots. Tegmina golden brown : anterior tibire red, femora black : posterior femora red: abdomen sanguineous. Body long 17 : length of one teg. $19 \frac{1}{2}$ millims.

Reported from N. India, Silhat, Tenasserim. The Indian Museum possesses specimens from Tenasserim, Arakan, and tho Khasiya Hills.

O31. Scieroptera fumigata.

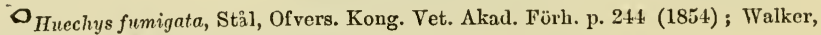
List Iom. B. M. Suppt. p. 314 (1858).

Scieroptera fumigata, Stål, Berl. Ent. Zoitschr, x, p. 169 (1866).

Head, thorax, and seutellum black; their lateral margins, a median patch on the thorax, and spot on the scutellum yellow: tegmina fuscovinaeeous, costa and veins weakly yellow testaceous; wings weakly vinaceous hyaline, abdomen and femora testaceous, the former above blackish. Body long 12 : exp. teg. 28 millims.

Reported from India. 


\section{Genus Graptotettix, Stål.}

IIem. Afric. iv, p. 4 (1866).

Allied toOGceana: tegmina with ten apical cells: vertex twice as wide as the eyes: anterior femora spinoso beneath; tibio longer than femora.

\section{O32. Graptórettix autratus.}

Graptotettiv guttatus, Stål, Berl. Ent. Zeitschr. x, p. 170 (1866).

Blackish with the frons, four oval spots on the thorax, two large spots on the scutellum, and the abdomen sordidly yellow: tegmina and wings fuscous. Body long 25 : exp. teg. 67 millims.

Reported from the Himálaya. The Indian Museum has a specimen from Sikkim.

$$
\text { O Genus Gæana, Amyot \& Serville. }
$$

Hist. Nat. Ins. Hém. p. 463 (1843).

\section{D33. Geana octonotata.}

o Cicada octonotata, Westwood, Arc. Ent. ii, p. 34, t. 57, f. 2, ९ (1843).

o IIuechys octonotata, Walker, List Hom. B. M. i, p. 253 (1850).

Easily reeognised by the tegmina brown with four yellowish spots and the wings roseate. Body long 37 : exp. teg. 61 millims.

Reported from Assam. The Indian Museum possesses specimens from Sikkim.

\section{O34. Grana Dives.}

O Tosena dives, Westwood, Arc. Ent. i, p. 98, t. 25, f. 2 (1842) : Am. et Serv. Hist. Nat. Ins. Hém. p. 464 (1843) : Walker, List Hom. B. M. i, p. 46 (1850).

Black: tegmina with reddish veins and a median transverse, narrow whitish band: wings testaceous, apical part black. Body long 25 : exp. teg. 75 millims.

Reported from Silhat. The Indian Museum possesses specimens from Sikkim.

\section{GEANa consors.}

Geana consors, White, Proc. Zool. Soc. 1850; Walker, List Hom. B. M. i, p. $253(1850)$.

Close to ${ }^{2}$. festiva, but differing in the markings on the tegmina. Body long 29 : exp. teg. 84 millims.

The Indian MIuseum possesses specimens from the Nága Hills and Samaguting in Assam. One specimen has the body above and below black without a single spot or mark exeept a testaceous tinge on the lower part of the face; and the markings on the tegmina are dark green. 
O36. Grana FESTIVA.

OTettigonia festiva, Fabricins, Syst. Rhyn. p. 41 (1803).

o Cicala thalassina, Percheron, Gen. Ins. (Hém.), t. 2 (1834) : Gnérin, Voyago La Coquille, Ins. p. 183 (1838).

o Cicada percheronii, Guérin, Icon. Règne Animal, p. 355 (1838).

b Gxana consobrina, White, Proc. Zool. Soc. 1850; Walker, List Ulom. B. M. i, p. $254(1850)$.

Greana festiva, Stål, Berl. Ent. Zeitschr. x, p. 170 (1866); Hem. Fabr. ii, p. 5 (1869).

Black : a testaceous band across the face from eye to eye and around each eye : four narrow lougitudinal yellow lines on the thorax. 'I'egmina bluish green or greenish yellow, the radial area with a small and larger spot below, a median band, three confluent apical patches, and a broad apical limbus, black: wings white or bluisl, apieal part black with a white or bluish spot on the disc. Body long 33: exp. teg. 80 millims.

Reported from Assam, Bengal.

The Indian Museum possesses specimens from Darjiling and Sikkim. Some of these have the tegmina green, other's greenish yellow, and, in some, the wings have the basal portion and a discal spot bright testaceous not white or pale, the size and arrangement of tho markings on the body and tegmina remaining exactly the same.

37. Geana maculata.

OTettigonia maculata, Fabricins, Syst. Ent. App. p. 831 (1775); Spoc. Ins. ii, p. 319 (1781) ; Mant. Ins. ii, p. 266 (1787) ; Ent. Syst. iv, p. 20 (1794); Syst. Rhyn. p. 37 (1803).

OCicada maculata, Drury, Ill. Nat. Hist. ii, p. 69, t. 37, f. 1 (1773); Ginelin, ed. Syst. Nat. i, pt. 4, p. 2100 (1782) : Olivier, Enc. Néth. v, p. 750, t. 112, f. 4 (1790): Germar in Thon's $\Lambda$ rchiv. ii, fasc. 2, p. 12 (1830); in Silbermann's Rev. Ent. ii, p. 74 (1834).

Geana maculata, Am. et Serv., Hist. Nat. Ins. Hóm. p. 464 (1843); Walker, List Hom. B. M. i, p. 253 (1850).

․ Black shining: two yellow spots on vertex between the eyes, one below each eye: six on mesonotum, four in front, two behind. Tegmina black, with five spots, two basal (of which one within radial area is minute) and three larger subequal median spots, whitish yellow : a white dot in 1-3 ulnar and in all the apical areas except the last. Wings black, basal part sordidly white and a sub-apical row of five white dots. A form of the $\delta$ has, instead of the dots or spots in the ulnar and apical areas, broad smears of dirty white, and is also larger than the ordinary ․ Body long 32: exp. teg. $\$ 2$ millims, 우 : body long 40 exp. teg. 97 millims. , form last mentioned.

The Indian Museum possesses specimens from Sikkim, Khasiya Hills, Samaguting, and the Dhansiri Valley. 
J 38. Geana sulphurea.

VCicala sulphurea, Hope, in Royle's 1ll. Bot. Him., Introd., p. liv, t. 10, f. 2 (1839).

O Cicala pulchella, Westwood, Arc. Ent. ii, p. 34, t. 57, f. 1. (1813).

Qieana sulphurea, Walker, List Hom. B. M. i, p. 254 (1850).

Black; head, pronotum, and mesonotum spotted sulphureous : tegmina and wings sulphureous for the basal two-thirds; apical third blackish-fuseons: tegmina with a blackish-fuseous median band: abdomen bencath and on each side at the tip, spotted yellow. Body long 38: exp. teg. 90 millims.

Reported from Nepal and N. India.

The Indian Museum possesses specimens from Sikkim and N. India.

0 Genus Dundubia, Am. \& Serv.

Am. et Serv., Hist. Nat. Ins. Hóm. p. 470 (18ษ3) : Stål, Hem. Afric. iv. p. 5 (1S66).

Hend triangular: frons large, very convex, transversely sulcated, with a longitudiual groove in the middle : pronotum not ampliated on the lateral margius : eheeks without a tubercle: rostrum not or barely reaching the bise of the posterior eoxæ: opercula long, extending beyond the middle of the venter, very often to the last segment.

This and the remaining genera of this group have been so imperfectly worked out, and the synonymy is so defective, that it is impossible for any one in this country to do more than indicate the recorded species. Walker's work here is particularly untrustworthy, and his descriptions quite unintelligible.

\section{39. Dundubia mannifera.}

0 Cicada mannifera, Linnæus, Mns. Ad. Fried. p. 84 (1754), excluding synonymy.

Tettigonia vayinata, Fabricins, Mant. Ins. ii, p. 266 (1787) ; Ent. Syst. iv, p. 18 (1794); Syst. Rhyn., p. 35 (1803).

O Cicada vaginata, Gmélin Ed. Syst. Nat. i, pt. 4, p. 2099 (1782) ; Olivior, Enc. Méth. v, p. 748 (1790); Stoll, Cig. p. 38, t. 7, f. 35 (1788).

() Cicada virescens, Olivier, Enc. Méth. $\nabla$, p. 747 (1790) t. 110, f. 2; Walker, List Hom. B. M1. i, p. 64 (1850).

O Dundubia vayinata, Am. et Serv., Hist. Nat. Ins. Hém. p. 471 (1843); Walker, List Hom. B. M. i., p. 47, 1120, (1850); J. L. S. Zool. x, p. 84 (1867).

Dundubia mannifera, Stål, Berl. Ent. Zeitschr. x, p. 170 (1860) : Distant, J. A. S. B. xlviii, (2), p. 38 (1879); Trans. Ent. Soc. p. 634 (1881).

Body pale yellow-olive or virescent, spotless; tegmina and wings hyaline, spotless, costa of the former black or brown; opercula almost as long as the abdomen, narrowed near the base, thence oval, rounded at the tip, testaceous or pale green. $\sigma^{\star}$. Body long 43: exp. teg. 110 millims. 
Reported from Morty, Sumatra, Tenasserim, Assam.

The Indian Museum possesses specimens from Java, Tenasserim, and Sikkim.

O 40. Dundubia microdon.

Dundubia microdon, Walker, List Hom. B. M. i, p. 55 (1850).

Body long, 34: exp. teg. 88 millims. Reported from N. India.

O41. Dundubia lateralis.

Dundubia lateralis, Walker, List Hom. B. M. i, p. 61 (1850).

Body long, 29 : exp. teg. 87 millims. Reported from Silhat.

O 42. Dundubia intemerati.

Dundubia intemerata, Walker, J. L. S. Zool. i, p. 8 \& (1856).

Pale testaceous: tegmina and wings liyaline, spotless, the costa of the former tawny, veins green. Opereula aeute, triangular, narrow, extending to fifth ventral segment. Body long 21 : exp. teg. 72 millims.

Reported from Singnpore.

Tho Indian Museum possesses specimens from Tenasserim, Dhansirivalley, Sibságar, Nága Hills, Samaguting.

\section{Dundubia vibrans.}

Dundubia vibrans, Walker, List Hom. B. M. i, p. 54 (1850) : J. L. S. Zool. x, p. 84 (1867).

Body pale tawny, wings colourless, pale tawny at the base; apex of tegmen slightly elouded with brown. Body long 36 : exp. teg. 92 millims.

Reported from Silhat.

0 44. Dundubia nicomache.

Dundubia nicomache, Walker, List Hom. B. M. i, p. 67 (1850).

Body long 22 : exp. teg. 85 millims. Reported from N. India.

O45. Dundudia tigrina.

Dundubia tigrina, Walker, List Hom. B. M. i, 69 (1850).

Body long 23: exp. teg. 69 millims. Reported from Malabar.

The Indian Museum possesses specimens from Assam?

046. Dundobia maculipes.

Dnndubia maculipes, Walker, List Hom. B. M. i, p. 70 (1850).

Body long 25 : exp. teg. 71 millims. Reported from N. Bengal. 16 


\section{Dundubia samia.}

Dundubia samia, Walker, List Hom. B. M. i, p. 77 (1850).

Body long 28: exp. teg. 71 millims. Reported from N. India.

(3) 48. Dundubia singularis.

Dundubia singularis, Walker, List Hom. B. M. Snppt. p. 7 (1858).

Body long 19 : exp. teg. 62 millims. Reported from India.

\section{49. Dundubia radha.}

Dundubia radha, Distant, Trans. Ent. Soc. p. 634 (1881).

Allied t $\oslash D$. mannifera, Linn., from which it differs by the much broader head, attenuated apices of the opercula, and its much larger size. In superficial appearance, it bears a strong resemblance to the genus O Cosmopsaltria. (Distant). Body long 53: exp. teg. 124 millims.

Reported from Madras Presidency and Mussooree.

\section{50. Dundubia tripurasura.}

Dundubia tripurusura, Distant, Trans. Ent. Soc. p. 635 (1881).

This species is allied tơ D. vibrans, Walker, from which it structnrally differs by the long and subtriangular opercula. The abdomen is also broader, the tegmina unspotted, and the sanguineous colour of the abdomen and opereula are also somewhat peculiar and distinct. (Distant). Body long 33 : exp. teg. 85 millims.

Reported from Assam.

\section{O5l. Dundubia nagaragingna.}

Dundubia nagarasingna, Distant, Trans. Ent. Soo. p. 635 (1881).

Distant writes:- ' I am somewhat at a loss for a closely allied species with which to compare it, but its distinct colour and markings and shape and the length of the opercula should sufficiently distinguish it.' Body long 39 : exp. teg. 95 millims.

Reported from N. W. Burna.

\section{O 52. Dundubia mmacula.}

Dundubia immacula, Walker, List Hom. B. M. i, p. 50 (1850).

Body fawn colour, wings whitish. Body long 40 : exp. teg. 102 millims. Reported from Tenasserim.

Genus Melampsalta, Kol.

Melet. Ent. vii. p. 27 (1857). 
O 53. Melampsalta varians.

0 Cicada varians, Germar in Silbermann's Rev. Ent. ii, p. 59 (1834).

Dundubia varians, Walker, List Hom. B. M. i, p. 48 (1850); iv, p. 1120 (1852): Snppt. p. 6 (1858).

O Dundubia chlorogaster, Walker (nec Boisdnval), l. c. p. 47,.

Melampsalta varians, Stal, A. S. E. F. (4 S6́r.) i. p. 619 (1862).

Reported from Silhat.

OGenus Cosmopsaltria, Stål.

Hem. Afric. iv, p. 5 (1866).

In Ofvers. Kong. Vet. Aka. Förh. p. 708 (1870), Stål distributes this genus amongst three subgenera :-Platylomia to which ${ }^{\circ} C$. flavida, Gnérin, belongs ; Cosmopsaltria to whieh ${ }^{\circ}$ C. spinosa, Fabr., belongs; and ${ }^{\circ}$ Diceropygia to which C. obtecta, Fabr., belongs. Cosmopsaltrio is elosely allied toDundubia; cheeks without a tubercle; rostrum reaching the base or nost often the apex of the posterior eoxæ; opercula long, extending beyond the middle of the venter.

054. Cosmopsaltria OBTECTA.

O Tettigonia obtecta, Fabricins, Syst. Rhyn. p. 35 (1803).

o Cicada obtecta, Germar, in Thon's Archiv, ii, fasc. 2,.p. 5 (1830).

O Dundubia obtecta, Walker, List Hom. B. M. i, p. 47 (1850).

Cosmopsaltria obtecta, Stål, Hem. Fabr. 2, p. 4 (1869).

Reported from N. India, N. Bengal, Nepál and Assam. Body long 25 : exp. teg. 85 millims.

Sprecimens in the Indian Museum are from Sikkim and Assam.

- 55. Cosmopsaltria sita.

Cosmopsaltria sita, Distant, Trans. Ent. Soc. p. 636 (1881).

It is difficult to separate this and the two following species from the gemis Dundubia except by the length of the rostrum. They also resemble the 'vibrans' group of that genus. Body long 24: exp. teg. 73 millims.

Reported from S. India or Bombay. (Distant).

D56. Cosmopsaltria durga.

Cosmopsaltria durga, Distant, Trans. Ent. Soc. p. 637 (1881).

This species in size and markings (exeluding the spotted tegminic) much resembles ${ }^{0}$ Dundubia tripurasura, Distant; the less produced frontal portion of the head and the length of the rostrmm, however, place it in this genus (Distant). Body long 33: exp. teg. 98 millims.

Reported from Assam.

\section{57. Cosmopsaltria abdulia.}

Cosmnpsaltria abdulla, Distant, Trans. Ent. Soc. p. 639) (1851).

This is a large and distinet species, near a. doryca, Boisd., from 18 
which it differs by its large size, more spotted tegmina, and different size and structure of the opercula. Body long 46 : exp. teg. 116-122 millims. lieported from Penang and Singapore.

\section{O58. Cosmopsaltria oopaga.}

Cosmopsaltria oopaga, Distant, 'Trans. Ent. Soc. p. 641 (1881).

This species is also allied to OC. doryca, Boisd., but the body is much broader, the tegmina are unspotted, and tho shape of the opercula more like those ofC. ablulla, Distant. Body long $39:$ exp. teg. 96 millims.

Reported from Burma.

\section{O59. Cosmopsaltria spinosa.}

Tettigonia spinost, Fabricius, Mfant. Ins. ii, p. 266 (1787); Ent. Syst. iv, p. 17 (1794); Syst. Rhyn. p. 34 (1803).

Cicada spinosa, Olivier, Enc. Méth. v, p. 748 (1790).

CDundubia spinosa, Walker, List Hom. B. M. i, p. 47 (1850).

Cosmopsaltria spinosa, Stål, Berl. Ent. Zeitsch. x, p. 171 (1866); Ofvers. Kong. Vet. Aka. Förh. p. 708 (1870).

Varies nuch in size and coloration. Tegmina towards the apex of the veins sonetimes immaculate and sometimes with fuscous spots.

Reported from India.

\section{O 60 . Cosmopsaltria flavida.}

OCicada favidu, Guérin, Voyago Belanger in Ind. Orient. p. 498, t. 3, f. 1, (183.1); Walker, List $11 \mathrm{~cm}$. B. M. i, p. 118 (1850).

O Dundubiu suturata, Walker, List Hom. B. M. Suppt. p. 6 (1858).

Cosmopsaltria fla vidu, Stàl, Berl. Ent. Zeitschr. x, p. 171 (1866). Sikkim.

Body long 45: exp. teg. 140 millims. Reported from Java and

\section{O Genus Leptopsaltria, Stål.}

IIem. Afric. iv, p. 5 (1866).

Allied to ODundubia, Am. et Serv.; cheeks with a tubercle near the apex; rostrum extending a little beyond the posterior coxæ; opereula short: seeonil and third segments of the abdomen in the $\delta$ with a literal tubercle.

\section{O 61. Leptopsaltria guttularis.}

O Cicalla guttularis, Walker, List Hom. B. M. Suppt. p. 29 (1858), ㅇ. .

Leptopsaltria guttularis, Stảl, Hem. Ins. Philip. in Ofvers. Kong. Vet. Akak. Förh. p. $710(1870), \delta$.

Very like ${ }^{\nu}$ L. tuberosa, Sign., but differs in the opercula being more obtuse, apex much less obliquely truncated, exterior apical part more oltuse, less produced, ventral tubercles of the $\delta$ larger, black. Body long 13 : exp. teg. 46 millins.

Reported from Burma. 
There are several unnamed species of this genus in the Indian Museum.

$$
\text { O Genus Pomponia, Stål. }
$$

Hem. Afric. iv, p. 6 (1866).

Allied to OCosmopsaltria: opereula short, somewhat transverse : rostrum reaching at least to the base but most often to the apex of the posterior coxæ. Stål (Ofverg. K. V.-A. Förh. p. 710, 1870) separates the subgenera Pomponia and Oncotympana.

\section{D62. Pomponia urania.}

ODundubia urania, Walker, List Hom. B. M. i, p. 64 (1850).

Pomponia urania, Stål, Berl. Ent. Zeitschr. x, p. 171 (1866).

Hind-scnteheon bright green; abdomen green. Body long 34 : exp. teg. 83 millims.

Reported from Hindustan.

\section{(2) 63 . Pomponia bindusara.}

Pomponia bindusara, Distant, Trans. Ent. Soc. p. 642 (1881).

This species, above, resembles ${ }^{O}$ Dundubia vibrans, Walker, and $P_{\text {Cos- }}$ mopsaltria sita, Distpnt. Many of these Indian species belonging to the generandundubia, Cosmopsaltria, andPomponia have a common facies in colour and markings which Distant thinks is probably due to mimetic resemblance, and which, in practice, renders their identification exceedingly diffieult. Body long, 30 : exp. teg. 87 millims.

Reported from Tenasserim.

D 64 . Pomponia linearis.

ODundubia linearis, Walker, List Hom. B. M. i, p. 48 (1850). Var., l. c. iv, p. 1120 (1852).

Dundubia ramifera, Walker, var., l. c. p. 53 (1850) : J. L. S. Zool. x, p. 84 (1867).

Dundubia cinctimanus, Walker, List l. c., p. 49 and Suppt. p. 6 (1858) : J. L. S. Zool. x, p. 84, (1867).

Pomponia linearis, Stål, Berl. Ent. Zeitschr. x, p. 171 (1866).

Body tawny. Body long 46 : exp. teg. 118 millims.

Reported from Silhat.

The Indian Museum possesses a specimen from Assam.

O65. Pomponia kama.

Pomponia kama, Distant, Trans. Ent. Soc. p. 643 (1881).

Allied to $O P$. transversa, Walker, but mnch smaller, abdomen narrowed and more linear, head broader in comparison with pronotum and colour different. Body long 18: exp. teg. 66 millims.

Reported from N. India, Darjiling. 
D 66. Pomponia madiata.

Pomponia madhava, Distant, Trans. Ent. Soc. p. 644 (1881).

Allied to OP. tigroides, Walker, from which it differs by its being pale greenish and unicolorous, the tegmina broader, with the costal margin irregularly curved and not deflexed at the termination of the radial veins, and also in having both tho second and third abdominal segments beneath rounded, produced and pointed anteriorly. Body long 22: exp. teg. 55 millims.

Reported from Assam.

\section{67. Pomponia imperatoria.}

0 Cicada imperatoria, Westwood, Aro. Ent. ii, p. 14, t. 51, (1843) : Walker, List IIom. B. M. i, p. 47 : J. L. S. Zool. i, p. 83 (1856) : ibid. x, p. 84 (1867).

P'omponia imperatoria, Stål, Berl. Ent. Zeitschr. x, p. 171 (1866). millims.

A very large species, yellow luteous, body long 88, exp. teg. 209

Reported from Nepál.

O 68. Pomponia tigroides.

Pomponia tigroides, Distant, J. A. S. B. xlviii (2), p. 38 (1879).

The Indian Museum possesses a specimen from Tenasserim.

0 Genus Emathia, Stål.

Hem. Afric. iv, p. 8 (1866).

Inner ulnar area of tegmina not widened towards the apex; apical cells one and two extending equally far forward; thorax widened at the base : tympana chiefly exposed; opercula short : anterior femora spinose.

\section{O 69 . Emathia eqrota.}

Emathia cegrota, Stål, Berl. Ent. Zeitschr. x, p. 172 (1866).

Body long 20 : exp. teg. 50 millims. Reported from Bombay.

\section{Genus Cicada, Linn.}

Linnaens, Syst. Nat. i, p. 704 (1766) : Stål, Rio. Jan. Hem. ii, p. 19 (1862) Ofvers K. V. A. Förh. p. 714 (1870).

\section{U7. Cicada subtincta.}

Cicada subtincta, Walker, List B. M. i, p. 147 (1850).

Body long 32 : exp. teg. 105 millims. Reported from Silhat.

$$
\text { U71. CiCADA ANEA. }
$$

Cicada anca, Walker, 1. c., p. 207 (1850).

Body long 13 : exp. teg. 40 millims. Reported from N. Bengal. 


\section{O72. Cicada aurata.}

Cicada aurata, Walker, 1. c., p. 215 (1850).

Body long 17 : exp. teg. 42 millims. Reported from Assam.

\section{- 73. Cicada subvitta.}

Cicada subvitta, Walker, 1. c., p. 222 (1850).

Body long 16 : exp. teg. 38 millims. Reported from N. India.

\section{O 74. Cicada ferruginea.}

Cicada ferruginea, Olivier, Enc. Méth. v, p. 750, t. 112, f. 1 (1790); Stoll, Cig. p. 65 , t. 16, f. 86 (1788); Walker, List Hom. B. M. i, p. 117 (1850).

Reported from India.

\section{O 75. Cicada xantes.}

Cicada xantes, Walker, List IIom. B. M. i, p. 198 (1850).

Body, drums, and legs tawny : wings colourless, veins yellow. Body long 17 : exp. teg. 48 millims.

Reported from N. India.

\section{- 76. Cicada maculicolis.}

Cicada maculicollis, Guérin, Voyage La Coquille, Zool., p. 183 (1830); Walker List Hom. B. M. Suppt., p. 28 (1858).

Body long 24: exp. teg. 65 millims. Reported from Bengal.

$$
\text { O Genus Cryptotympana, Stål. }
$$

A. S. E. F. (4 Sér.), i, p. 613 (1862).-Hem. Afric. iv, p. 6 (1866).

\section{o 77. Cryptotympana recta.}

OFidicina recta, Walker, List Hom. B. M. i, p. 79 (1850)

- Cryptotympana recta, Distant, J. A. S. B. xlviii (2), p. 40, t. ii, f. 4 (1879), of .

Body long 32 : exp. teg. 95 millims. Reported from Silhat and Tenasserim.

The Indian Museum possesses a specimen from Tenasserim.

078. Cryptotympana vicina.

0 Cicada vicina, Signoret, Rev. Mag. Zool., p. 410, t. 10, f. 4 (1849).

Fidicina vicina, Walker, List Hom. B. M. i, p. 90 (1850).

Cryptotympana vicina, Stal, A. S. E. F. (4 Sér.) i. p. 613 (1862).

Reported from Silhat.

The Indian Museum possesses specimens from the Bhutan Duárs. 


\section{O 79. Cryptotympana immaculata.}

CCicada immaculata, Olivier, Ene. Méth. v, p. 749, t. 112, f. 7 (1790) : Stoll, Cig. p. 40, t. viii, f. 39 (178s) : Signoret, Rev. Mag. Zool. p. 410 (1849).

O Fidicina immaculata, Walker, List Hom. B. M. i, p. 90 (1850); iv, p. 1121 (1852). Cryptotympana immaculatu, Stål, A. S. E. F. 4 Sèr. i. p. 613 (1862).

Reported from N. Bengal.

o 80. Cryptotympana intermeda.

(Cirrata intermedia, Signoret, Mag. Rev. 7ool. p. 406, t. 10, f. 2 (1849).

() Fidicina intermedia, Walker, List Hom. B. M. i, p. 90 (1850).

Cr!̣ptutympana intermedia, Stål, A. S. E. F. 4 Sér. i. p. 613 (1862).

Abdomen redulisli yellow with a blackish band on each segment allied to $C$. atrata, Fabr.

Reported from Tenasserim.

- Gemus Fidicina, Amyot \& Serville.

Anyot et Serville, Hist. Nat. Ins. Hém. p. 472 (18+3) : Stå], Rio. Jan. Hem. ii p. 18 (1862); Ann. Soe. Ent. Fr. (4 sér) i, p. 614 (1861); Hem. Afric. iv, p. 7 (1866); Distant, Biol, Cen. Amer. p. 16 (1881).

- 81. Fidicina operculata.

Dicada operculata, Carreno. -

Fillicina operculata, Walker, List Hom. B. M. i, p. 90 (1850).

Reported from N. India.

The Indian Musenm possesses a specimen.

O 82. Fidicina corvus.

Fidicina corvus, Walker, List Hom. B. M. i, p. 86 (1850).

Reported from Silhat. Body long 29 : exp. teg. 113 millims.

'The Indian Museum possesses a specimen of the $\ell$ from Silhat.

O Genus Tibicen, Latreille.

Latreille, Fam. Nat. p. 426 (1825) : Stål, Hem. Afric. iv, p. 25 (1866).

(1). Tibicen aurengzebe.

Tibicen aurengzebe, Distant, Trans. Ent. Soc., p. 616 (1881).

Body long 18: exp: teg. 48 millims. Reported from Bombay Presidency.

84. Tibicen apicalis.

0 Cicada apicalis, Germar in Thon's Arehiv, ii, fasc. 2, p. 8 (1830); in Silbermann's Rev. Ent. ii, p. 63 (1834); Walker, List Hom. B. M. i, p. 161 (1850).

Tibicen apicalis, Stål, A. S. E. F. 4 Sér., i, p. 618 (1862).

Body long 18: exp. teg. 48 millims., ㅇ. Reported from N. India.

The Indian Museum possesses a specimen from Calcutta. 
O Genus Mogannia, Amyot \& Serville.

Amyot et Serville, Hist. Nat. Ins. Hém, p. 467 (1843) : Stål, Hem. Afric. iv. p. 5 (1866).

\section{Mogannia iliustrata.}

Mogannia illustrata, Am. et Serv., Hist. Nat. Ins. Hém. p. 467, t. 9. f. 4 (1843) ; Walker, List Hom. B. M. i, p. 248 (1850).

Body uniform ferruginous brown: basal half of tegmina and a small semicireular patch on the tips, transparent yellow, a brown transverse band across the middle. Body long, 12 millims.

Reported from N. India.

O86. Mogannia recta.

Mogannia recta, Walker, List Hom. B. M. Snppt. p. 39 (1858).

Abdomen with a red band on the posterior border of each segment. Body long, 12 millims.

Reported from Hindustan.

087. Mogannia obliqua.

Mogannia obliqua, Walker, List Hom. B. M. Suppt. p. 39 (1858).

. green mostly reddish beneath : abdomen reddish with a spot on each side near the base. Pronotum and mesonotum with some testaceous marks. Body long, 14: exp. teg. 41 millims.

Reported from Hindustan.

\section{O88. Mogannia renustissima.}

Mogannia venustissima, Stål, Ofvers. Kong. Vet. Aka. Förh. p. 15+ (1865).

Crerulean or metallic black. Tegmina with the reins at the bise pale sangnineous, before the middle black, thenee sordid straw-colour: wings with the veins at the base sanguineons and thence piceous. Borly long, 16 : exp. teg. $37-41$ millims.

Reported from E. India.

\section{O 89. Mogannia funebris.}

Mogannia funebris, Stål, Ofvers. Kong, Vet. Aka. Förlı. p. 155 (1865).

Aeneous black. Tegmina, before the midḍle, black with the hasal areola and a band towards the apex of the black part sordid lnteseent. $f$ Body long, 19 : exp. teg. 46 millims.

Reported from Silhat.

\section{Mogannia indicans.}

Mogannia indicans, Walker, List Hom. B. M. i p. 249 (1850).

$\delta$ bright or dark red, 9 black. Tegmina witl a broad basal browu band, veins yellow. Body long $12-16$ : exp. teg. 35-40 millinss. 
Reported from China.

The ludian Mnsenu possesses specimens from Sikkim.

\section{O91. Mogannia locusta.}

O'phlulorys locustu, Watker, List Hom. B. M. i, p. 236 (1850).

Bodly ferruginous beneath and abdomen pale tawny. Body long 50 : exp. tog. 8. millims.

Ri'ported firom E. India.

\section{O9:2. Mogannia lacteipennis.}

Or'ephalon:ys lucteipennis, Walker, List Hom. B. M. i, p. 237 (1850).

Body huteous : abdomen black with the hind borders of the segments tawny: tegmina and flar ps white, opaque, luteous at the base. Borly long 36: exp. teg. 97 millins (?).

keported from N. Incliat.

\section{93 . Mogannia quadrimacula.}

$O$ ('rphuloxys quadrimuculu, Walker, List Hom. B. M. p. 238 (1850).

Body briglit tawny : hind margins of abdomen having the borders of the segments witls slender interrupted reddish bands, a broad pale tawny hand near the tip and beneath, piceous. Body long 30 : exp. teg. 53 millims.

kicported from N. India.

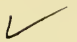

\section{O94. M. TERPSICHORE.}

UCephaloxys terpsichore, Walker, List Hom. B. M. p. 239 (1850).

Body apple-green : abdomen with two last segments pitchy alove : tegmina eolourless, tinged with brown towards the tips, costa green. Body long 25: exp. teg. 74 millims.

Reported from K. India.

\section{Correction and Addition.}

Page 213,4 lines from top of page, for "Nicobarica," read "Distincta," the former of these names being praeocupied; and, between the $10 \mathrm{th}$ and 11 th lines from bottom of page, insert

$$
\text { 0"5* Plítypleura nicobarica. }
$$

Platypleura nirobarica, Butler, Ann. \& Mag. Nat. Hist. April, 1877.

Reported from the Nicobars." 



\section{Notes on Intian Rhynchota, No. 2.-By E. T. Atrinson, B. A.}

[The notes are taken so far as possible from the original descriptions or from Stål, Signoret, Butler, or Distant, \&c. where these writers liave redescribed a species. The measurements of specimens not in the Indian Museum have been converted into millimetres from the recorded measurements of the several author's.]

[Received Feb. 17th ;-Read March 4th, 1885.]

\section{HOMOPTERA.}

\section{Family Cercopida.}

C Cercopida, Stål, Hem. Afric. iv. p. 54 (1866): Hem. Fabr. ii. p. 11 (1869). Fieber, Rev. Mag. Zool. (3 sér.) iii. p. 328 (1875) Cercopina Stål, Ofvers. Kong. Vet. Aka. Förh. p. 718 (1870).

Frons convex or compressly produced : ocelli two on the vertex near the base : thorax, large, sexangular or trapezoidal: scutellum small or molerate, triangular; tegmina usually coriaceous : feet remote from the sides of the body with the coxæ (especially the posterior pair) short: tibia romuled, posterior furnished with one or two spines and with a circlet of spinules at the apex.

O Subfamily Cercopina, Stål.

PCercopila, Stål, Hem. Afric. iv. p. 55 (1866) : Hem. Fabr. ii. p. 11 (1869) : Cercopina, Stål, Ofvers, Kong. Vet. Aka. Förh. p. 718 (1870).

Anterior margin of thorax straight, eyes equally long and broad.

In 1874, Mr. Butler of the British Museum (Cist. Ent. i. p. 245) recorded the species of the genera Cosmoscarta and Phymatostetha, formed by Stål from the genus Cercopis of Walker (nec Fabricius). He enumerated 104 species of the genus Cosmoscarta and 22 species of the genus Phymatostetha. Since then, the number of species of the genus Cusmoscarta has been increased by eight of which five, described by $\mathrm{Mr}$. Distant, come from India and the Eastern Archipelago, and three, described by Mr. Butler, come from Penang and Sumatra. The number 
of species of the genus Phymatostetha has been inereased by two, of which one comes from Ceylon and one from Assam; both lave been described by Mr. Distant. The Indian Museum possesses about ten, apparently undescribed, species which may be referred to these genera, and which will form the subject of a separate paper hereafter.

\section{- Genus Cosmoscarta, Stål.}

Hem. Fabr. ii. p. 11 (1869) : Ofvers. Kong. Vet. Aka. Förh. p. 718 (1870).

Frons very large, very tumid, obtuse, extended on the facial side almost to the eyes, devoid of any longitudinal furrow or keel.

\section{- 1. Cosmoscarta tricolor, St. Farg. and Serv.}

- Cercopis tricolor, St. Fargeau and Serville, Enc. Méth. x. p. 605 (1825) : Burm. IIandb. Ent. ii. (i) p. 124 (1835) : Walker, J. L. S. Zool. i. p. 95 (1856); ibid., p. 165 (1857).

Cosmoscarta tricolor, Butler, Cist. Ent. i. p. 245 (187t) : Distant, J. A. S. B. xlviii (2) 1. 38 (1879).

Black, shining: head, thorax, sentellum towards the tip, hind borders of the abdominal segments, the tip of the abdomen and the legs, red : femora black, the four anterior red towards the tips: six red spots on each tegmen at the base. A Tenasserim variety in the Indian Musenm differs from the type in having the subbasal fascia represented by a transverse series of four sanguineous spots; there is also a spot of the same colour at the base. It is thus intermediate between $V_{C}$. tricolor and $C$. basinotata, Butler (Cist. Ent. i. p. 245), which differs also in the coloration of the abdomen (Distant). Body long 22 : exp. teg. 51 millims.

Reported from Borneo, Java, Singapore, and Tenasserim ; a specimen from the last locality is in the Indian Museum.

\section{- 2. Cosmoscarta basinotata, Butter.}

Cosmoscarta basinotata, Butler, Cist. Ent. p. 245, t. viii, f. 2, (1874) : Distant, J. A. S. B. xlvii (2) p. 194 (1878).

Form of ${ }^{\circ} C$. tricolor : differs chiefly in having the tegmina crossed at the base by a patch of six red spots (that on the clavns being more or less bifid) instead of the pale testaceous band, and in the narrower and interrupted red bands margining the segments on the dorsum of the abdomen (Butler). Long. 21 : exp. teg. 47 millims.

Reported from Sarawak, Tenasserim. 
- 3. Cosmoscarta moorei, Distant.

Cosmoscarta moorei, Distant, Trans. Ent. Soc. Lond. p. 321 (1878.)

Black, shining : tegmina with the base both above and below carmine. 'This coloration consists of a narrow straight subcostal streak of ubout 3 millims. in length and a broader claval streak of about the same length, gradnally rounded and narrowed at its termination: wings fuscous; costal elge, for ahout half the length, narrowly tinged with "armine : eyes luteous : posterior border of sentellum, metanotum, and abdominal segments, apex and lateral borders of abdomen, carmine: anterior legs dull recldish, femora furnished with a strong spine; intermediate legs pitcliy: mesosternum with two very large conical, thick teeth. Bocly long 13 : exp. teg. 35 millims.

Reported from Sikkim.

¿ Cercopis fuscipennis, St. Farg. \& Serv., Enc. Méth. x. p. 605 (1825.)

- Cercopis plana, Walker, List Hom. B. M. iii. p. 653 (1851) : J. L. S. Zool. i. p. 95 (1856) : ibid. x. p. 276 (1867).

Cosmoscurta fuscipennis, Stål, Hem. Fabr. 2 p. 11 (1869) : Batler, Cist. Ent. i. p. 216 (1874).

Black : liead, chest, rostrum except its black tip, and the fore-border of the tegmina from one to two-thirds of its length, red: wings dark grey. Thorax sometimes with two black points. Body long 12: exp. teg. 27 millims.

Reported from Java, Penang, Mount Ophir, Malabar (Walker).

- 5. Cosmoscarta megamera, Butler.

- Cercopis nigripennis, Walker (nec Fabricins), List Hom. B. M. iii. p. 653 (1851).

Cosmoscarta megamera, Butler, Cist. Ent. i. p. 246, t. viii. f. 3 (1874) : Distant, J. A. S. B. xlviii. (2), p. 38, (1879).

Form and general coloration of $O$. fuscipennis (St. Fargeau), bat at once distinguished by its much greater size, black legs, the narrower reddish costal edge and less pronounced basal reddish diffusion on tegmina. The colour of the thorax and head also varies from piceons to castaneons and bright testaceons (Butler). Body long 16-19: exp. teg. $39-47$ millims.

Reported from Hong-Kong, Laos, Java, Penang, Tenasserim, Silhat : the Indian Museum possesses specimens from Sikkim, Sibságar, Nága Hills, and Tenasserim.

- 6. Cosmoscarta foneralis, Butler.

Cosmoscarta funeralis, Butler, Cist. Ent. i. p. 247, t. viii, f. 4 (1874).

Form of $C$. fuscipennis, St. Far. \& Serv., but thorax with a distinct central ridge: head and thorax dark castaneous; scutellum piceous, 
dorsum of abdomen reddish-orange; tegmina piceons, almost black; wings fuscons; pectus black; venter and legs red; segments transversely banded and laterally spotted with black; proximal extremities of femora blackish (Butler). Body long 20 : exp. teg. 41 millims.

Reported from India.

- 7. Cosmoscarta masoni, Distant.

Cosmoscarta masoni, Distant, J. A. S. B. xlvii (2); p. 194 (1878) : xlviii. (2), p. 40 , t. ii, f. $6,(1879)$.

Pronotum stramineous with a quadrate black spot on the anterior margin : head (except basal portion), and eyes luteous : tegmina, pectus, legs, and abdomen shining black: prosternum with lateral borders stramincous : wings dark fuscons with the veins black \&. Body long (excl. teg.) $17:$ exp. teg. 45 millims.

Reported from Burma, Tenasserim : type from the latter locality in the Indian Museum.

\section{- 8. Cosmoscarta viridans, Guérin.}

$\checkmark$ Cercopis viridans, Guérin, Voy. Bél. Ind. Orient. p. 501; Atlas, t. 3, f. 7, 7a (1834) : Walker, List IIom. B. M. iii. p. 654, (1851); J. L. S. Zool. x. p. 279, (1867).

o Cercopis latissima, Walker, List Hom. B. M. iii. p. 655, (1851).

Cosmoscarta viridans, Batler, Cist. Ent. i. p. 249, (1874).

Black, shining: tegmina shining metallic blackish-green, convex along the fore-margin which is dilated towarls the base; wings fuscous, veins black, rostrum, feet, and nnus coccineous. Body long 15 : exp. teg. 46 millims.

Reported from Coromandel, Java, Sumatra, Mysol, New Guinea.

- 9. Cosmoscarta egens, Walker.

o Cercopis egens, Walker, List Hom. B. M. Suppt. p. 171, (1858).

Cosmoscarta egens, Butler, Cist. Ent. i, p. 255, (1874).

Thorax and head black, shining: scutellum, metanotum, abdomen at the base and along the posterior margin of each segment, and the legs red: tegmina very red at the base and with a roscate band before the reticnlated apical third, this band is sometimes narrow or indistinct or even obsolete: wings brown, rosy red at the base and along the adjoining part of the costa. Body long 11 : exp. teg. 31 millims.

Reported from India, Penang: the Indian Museum possesses specimens from the Nága and Khasiya hills.

- 10. Cosmoscarta ducens, Walker.

- Cercopis ducens, Walker, List Hom. B. M. ii. p. 655, (1851) : Stảl, A. S. E. F. (4 sér.) v. p. 188, (1865).

Cosmoscarta ducens, Butler, Cist. Ent. i. p. 255, (1874). 
Black, rustrum and legs piceous; abdomen slining violacents; teguina blackish-burown with two narrow, slightly mululuting, sordid singuinems bauls; one, near the base; the other, at two-thirds of the length: wings dark brown, veius black. Body long, 16 : exp. teg. 40
millims.

Reported from Silhat: the Indian Museum possesses a specimen from the Nigra hills.

\section{a 11. Cosmoscarta lydia, Stål.}

o Cercopis lydia, Stål, Ofvers. Kong. Vet. Aka. Förh. p. 149, (1865).

Cosmuscartu lydia, Butler, Cist. Ent. i. p. 257, (1874).

Brick red or saffron-yellow : head, anterior part of thorax, scutellum (except the frena), tegmina, anterior lateral part of prostetlinm, metistethimm, anns and talsi, black : base of tho tegmina brick-red or saflirun-yellow: wings sordilly liyaline, apex very slightly infuscate, base pialcly sitfion. Borly long 8-10 : exp. teg. 20-23 millims.

Sometimes tegmina have no saffron bands and sometimes have two, one before and the other behind the middle.

Reported from E. India.

a 12. Cosmoscarta trigona, Walker.

Ciercopis trigona, Walkor, List IIom. B. M. iii. p. 660, (1851).

(. C'urcopis umplicollis, Walker, l. c. Suppt. p. 175, (1858).

Cusmoscarta trigona, Butler, Cist. Ent. i. p. 257, (1874).

Thorax metallic bluish-black, shining : borders of scutellum, posterior margin of segments of abdomen, the anus, coxw and femora, and the tarsi at the base, red : tegmina bluish-black, tips brown, with a bifurcated basal streak and two bands, red; the basal streak with the median band contian letween them an almost triangular pateh, bhish black: tho limb of the hasal lifureation on the hind border is much broader than that on the costal min'rin, neilher quito reach the median band. Body long 10-12 : exp. teg. 23-29 millims.

Reported from N. India.

The Indian Museum possesses specimens from the Kliasiya and Nága hills, the Dhansiri valley, and Sibságar.

O 13. Cosmoscarta decisa, Walker.

U Cercopis decisa, Walker, List Hom. B. M. Suppt. p. 175, (1858).

Cosmoscartu decisa, Butler, Cist. Ent. i. p. 258, (1874).

A second species described under this name by Walker (in J. L. S. Zool. x. p. 278, No. 296, 1867) has been renamed $O$. zonata by Butler (in Cist. Ent. i. p. 253, 1874). Walker describes $C$. decisa thus: "Black: head above and prothorax æneous-green, shining: prothorax 
with a rery indistinct keel : tegmina whitish testaceous at the base and with two whitish testaceous bands; middle band almost equal in breadth and parallel to tho basal one; exterior band contracted hindward: wings greyish-vitreous." Body long $7 \frac{1}{2}$ : exp. teg. 17 millims.

Reported from Darjiling. The Indian Musemn possesses a specimen from Sikkim.

\section{- 14. Cosmosoarta undata, Walker.}

0 Cercopis undata, Walker, List Hom. B. M. iii. p. 659, (1851) : Stål, Ofvers. Kong. Vet. Aka. Förh., p. 148, (1865).

Cosmoscarta undata, Butler, Cist. Ent. i. p. 258, (1874).

Black : abdomen shining violaceous : thorax and the spots or bands on tegmina croceous or rufous-testaceous; an anterior transverse spot on the thorax and the posterior part, black: wings slightly infuscate, veins rufescent towards the base.

0 Var. a. Postcrior half of thorax black: tegmina with almost the fifth hasal part, posteriorly sinuated, a waved band a little before the middle, somewhat interrupted towards the claval suture, also a band beyond the middle, produced posteriorly in its mildle, sometimes divided into three spots, rufous-testaceous. Body long 13 : exp. teg. 30 millims.

This variety is reported from the Himálaya and the Indian Museum possesses specimens from Sibságar, Assam, and Arakan

- Var. $b$. about tho fourth basal part of the thorax, black: tegmina with a waved band before the middle, twice subinterrupted, cmitling at the costal and scutellary margins a stripe, sinuated within, also with three spots disposed in a curved row beyond the midlle, the two extcrior often confluent, rufous-testaceous. Body long 9-10: exp. teg. 24 millims.

Reported from Penang.

\section{- 15. Cosmoscarta bispecularis, White.}

- Cercopis bispecularis, White, A. \& M. N. H. xiv. p. 426, (18.t) : Walker, List Hom. B. M. iii. p. 656, (1851) : Stål, Stettin Ent. Zcit. xxii. p. 153, (1866).

Cosmoscarta bispecularis, Butler, Cist. Ent. i. p. 259, (1874).

Cinnabar, shining : thorax with two very large, nearly oval, black spots in front of which are two small, nearly round, black spots; pectus black ; underside of abdomen with two black bands: tegmina with a short black stripe at the base, near which three nnited black spots form a curved band across the wing; another band is formed in the niddlo by three separate black spots; reticulated part at the tips brown; wings grey, red at the base, brownish along the hind borders and at the tips. Borly loug 11-12 exp. teg. $26-29$ millims.

Reported from India, Almora, N. W. P., Penang : the Indian MLuseum possesses specimens from Assam. 


\section{Cosmoscarta dorstmacula, Walker.}

O Cercopis dorsimacula, Walker, List Hom. B. M. iii. p. 658, (1851) : J. L. S. Zool. i. p. 95, (1856) : ibid. p. 165, (1857).

- Cercopis quadrimaculata, Walker, 1. c. p. 66I, (1851).

$\checkmark$ Cosmoscarta dorsimacula, Butler, Cist. Ent. i. p. 259, (1874).

Walker's Cercopis dorsimacula in List Hom. 1. c. p. 663, No. 41, is different and was renamed by him Cercopis tomentosa in J. L. S. Zool. x. p. 284, (1867) : it now stands as Phymatostetha stellata, Guérin ( $q . v)$.

Briglit red shining: head with a short transverse streak along each side of the lind border; thorax with two very large black spots on each side of the disc and two smaller spots in front ; pectus and abdomen towarls the hase, black : a row of black spots on each side of the abdomen, of which the underside, except the hind borders of the segments, is black; tegmina red with seven black spots, six large and more or less confluent form two curved bands; reticulated part lurid : wings lurid, red at the base; veins brown, red towards the base (Walker). Body long 12-14 : exp. teg. 36-39 millims.

b Var. a. abdominal segments with black bands.

() Var. b. Body and tegmina testaceous with the usual spots.

Reported from N. Bengal.

\section{- 17. Cosmoscarta fictilis, Butler.}

Cosmoscarta fictilis, Butler, Cist. Ent. i. p, 259, (1874).

Allied to preceding but differs in its usually smaller size, narrower thorax, duller and more miform colouring and much smaller and more regularly uniform black spots (Butler). Body long 12: exp. teg. 32 millims.

Reported from Penang, India, Silhat.

\section{- 18. Cosmoscarta dorsalis, Walker.}

$\checkmark$ Cercopis dor'salis, Walker, List Hom. B. M. iii. p. 658, (1851).

C) Cercopis connexa, Walker, List 1. c. p. 663, (1851).

Cercopis ramosa, Walker, Ins. Saunds. Hom. p. 85, (1858).

L. Cosmoscarta dorsalis, Butler, Cist. Ent. i. p. 260, (1874).

Walker describes $C$. dorsalis, thus :- " Piceons shining; shield very minutely puncturer, impressed on each side in front; tilir and feet ferruginons; tegmina red, black on the reticulated part; eight large, partly confluent, black spots on membranous part: wings brown, veins black." Body long 9 : exp. teg. 25 millims.

Reported from N. India. 
- 19. Cosmoscarta pallida, Walker.

- Cercopis pallida, Walker, List Hom. B. M. iii. p. 657, (1851).

- Cercopis ferruginea, Walker, List 1. c. p. 660, (1851).

$\checkmark$ Cosmoscarta pallida, Butler, Cist. Ent. i. p. 265, (1874).

Walker describes C. pallida, thus:-“"Testaccons, head black, transversely striated, very convex in front: rostrnm testaceous : abdomen brown, testaceous at the base, and at the tip: tips of the feet brown : tegmina lurid, brown towards the tips: wings grey, veins brown." Body long 11-13 : exp. teg. 29-33 millims.

Reported from India.

\section{- 20. Cosmoscarta elegantula, Butler.}

Cosmoscarta elegantula, Butler, Cist. Ent. i. p. 265, (1874).

Allied to preceding: head and thorax metallic greenish black: abdomen purplish black, eastaneous at the tip: tegnina piceous, veins of basal half testaceons: base and a transverse band at end of second third reddish-orange : wings slightly fuscescent; base rufescent (Butler). Body long 8 : exp. teg. 20 millims.

Reported from India.

\section{- 21. Cosmoscarta pictilis, Stål.}

- Cercopis pictilis, Stål, Ofvers. Kong. Vet. Aka. Förh. p. 249, (1854).

Cosmoscarta pictilis, Butler, Cist. Ent. i. p. 266, (1874).

Obscurely green ehalybeous; scutellnm on both sides at the base and at the apex weakly spotted with einnabar : tegmina sordidly white, basal margin and two bands weakly cinnabar; two spots, one smaller before the first band and the other between the bands and the apex nigro-fuscous : femora red ; tibia blackish. Long, 16 ; breadth of pronotum 6 millims. Butler writes that it seems allied to $P$. signifera, Walker from the description and in that case wonld be a Phymatostetha.

Reported from E. India.

- 22. Cosmoscarta borealis, Distant.

Cosmoscarta borealis, Distant, Trans. Ent. Soc. p. 321, (1878).

Head and pronotum luteous, antennæ black : abdomen and tegmina roseate, ocelli black, eyes lutcous thickly covered with blackish markings : wings pale fuscous : pectus, coxæ, and femora luteous, fore and median tibiæ black, hind tibiæ luteous with the apex black: the tip of the rostrum, tarsi, and a strong spine near the apex of the hind tibiæ, black. Body long 6 : exp. teg. 17 millims.

Reported from the Kliasiya hills.

10 


\section{- 23. Cosmoscarta andamana, Distant.}

Cosmoscartu andumana, Distant, Trans. Ent. Soc. p. 175, (1878) : Waterhouse, Aids litent. Ins. i. t. 58 (1880-82).

Sanguineous, finely and closely punctured : tegmina with a broad band across the middle and the apex broadly black: these bands are nnited at the inner margin, sometimes very broadly: wings sordidly hyaline with veins much darker, base slightly sanguineous: femora, tibire and tarsi piceons, hind tibire with an acute spine (Distant). Body long 9 : exp. teg. 24 millims.

Reported from the Andaman Islands.

\section{U Genus Phymatostetha, Stål.}

Ofvers. Kong. Vet. Aka. Förh. p. 721, (1870).

Frons tumid, seldom forming an angle below the middle, without a keel or longitudinal impression. Ocelli nearer each other than the eyes. Thorax with the posterior margin before the scutellum slightly sinnated posterior lateral margins straight or sinuated. Mesosternum furnished posteriorly with two conical tubercles. Feet moderate, posterior tibio armed with one or two spines.

\section{Pirymatostetha stålit, Butler.} (1865)

Tomaspis circumducta, Stål (nec Walker), Ofvers. Kong. Vet. Aka. Förh. p. 150,

Phymatostetha circumducta, Stål 1. c. p. 721, (1870).

$\checkmark$ Phymatostetha stàliii, Butler, Cist. Ent. i. p. 267, (1874).

Blackish : frons, apices of the lobes of the vertex, apical and lateral margins of anterior part of the thorax, scutellum before the middle, two bands on the tegmina, equally removed from each other and from the base and the apex, the anterior small stripe on the corium, and the scutellary limbus of the elavus beyond the middle, sordidly lutescent: apical limbus of corium pellucid fuscous : wings fuseous, subsangnineous at the base: scntellnm subequilateral; mesostethium with two distinct obtuse tubercles. Body long 14 : exp. teg. 34 millims.

Reported from E. India.

c) 25. Рhymatostetha circomducta, Walker.

O Cercopis circumducta, Walker, List Hom. B. M. Snppt. p. 175, (1858).

Cercopis costalis, Walker, List, 1. c. iii. p. 664, (1851)-

V Phymatostetha circumducta, Butler, Cist. Ent. i. p. 268, (1874).

The name $C$. costalis (l. c. iii. p. 664), had already been given to a local form of " $C$. theora, White, by Walker (l. c. iii. 651) and was subsequently changed by him to $C$. circumducta for this species. 
Black : head slining : frons with a semicircular luteous band which is prolonged in a conical form to the face which on each side is yellow : rostrum yellow, tip pitehy: prothorax with a luteous band along the fore border extending on each side to the base of the tegmina, scutellum lurid on each side; pectus with large yellow marks on eacli side : abdomen purplish black with yellow bands at the tip, ventral surface yellow with three rows of transverse black spots, the side rows on the edge : legs tawny, femora and fore tibiæ brown, femora yellow beneath: tegmina dark brown with two narrow pale red bands, one at one-third, the other at two-thirds of the length, a yellow stripe extending along the foreborder from the base to the first band where it acquires a tawny hue, a pale red stripe extending along the hind-border from the base nearly to the first band: wings pale brown, almost colourless in part of the disc, luteous at the base, veins black (Walker). Body long 12: wings long 15 millims. A variety has two subapical spots on the tegmini red.

Reported from Malabar, Singapore.

\section{- 26. Phymatostetha milaris, Walker.}

Cercopis hilaris, Walker, List Hom. B. M. iii. p. 665, (1851).

- Phymatostetha costalis, Stål, Ofvers. Kong. Vet. Aka. Fürh. p. 721, (1870).

$\checkmark$ Phymatostetha hilaris, Butler, Cist. Ent. i. p. 268, (1874).

Black : head shining; frons with a semicireular luteous band which is prolonged in a very broad conical form and occupies the disc of the face: the latter is pitchy, sides and epistoma yellow, rostrum yellow with a black tip: prothorax with a luteous ban'd along the fore-border, extending on each side to the base of the tegmen : pectus yellow, disc black : with $2-3$ black spots on each side : abdomen purple, under-side yellow with three rows of transverse black spots, the side rows on the edge which is very broad: tegmina dark brown with two narrow yellow bands : the first at one-third of the length, interrupted on the disc and marked by some dots thence to the hind border ; the second, at two-thirds of the length, slightly waved: a yellow spot on the disc between it and the tip; a yellow stripe extending along the fore border from the base to the first band: wings greyish, tinged with brown at the tips and along the hind borders, luteous at the base. Body long 10 : exp. teg. 25 millims (Walker). Stål, 1. c. makes this a synonym of C. costalis, Walker.

Reported from Malabar.

\section{Phymatostetha stellata, Guérin.}

- Cercopis stellata, Guérin, Icon. Règne Anim. Texte. p. 368, (1829-44) : Stål, Ofvers. Kong. Vet. Aka. Förh. p. 150, (1865).

O Cercopis dorsimacula, Walker, List. Hom. B. M. iii. p. 663, (1851) : J. L. S. Zool. ?. 95, (1856). 
O Cercopis tomentosia, Walker, J. L. S, Zool. x. p. 284, (1867).

- Phymatostetha stellutu, Stâl, Ofvers. Kong. Vet. Aka. Förh. p. 721, (1870) : Butler, Cist. Ent. i. p. 269), (187-1).

Black, dull : heal with a band in front of the eyes, two spots on the dise of the thorax, the lateral margins of the thorax, a spot on each side of tho seutellum at the base, eighti spots on each tegmen of which ono is at the base, three are costul or subcostal, three near the hind-broader and one near the tip, luteous: narrow apical limbus, lurid: wings brown, rufescent at the base, veins bluck. Body long 17 : exp. teg. 37 millims.

Reported from Malabar, Malacea, Sumatra: the Indian Museum possesses a specimen from Johore.

\section{Puymatostetha dorsivitita, Walker.}

C) Cercopis dorsivitta, Walker, List Hom. B. Mr. iii. p. 662, (1851).

- Var. Cercopis humeralis, Walker, List 1. o. p. 662, (1851).

Phymatostetha dorsivitta, Butler, Cist. Ent. i. p. 269, (187-4).

13lack slightly shining : head.red, black on each side in front and along the hind border : thorax with three red stripes, the side pair oblique and extending on each side from the fore border to the base of the tegmina; ablomen purple above, red at the tip and on each side : tegmina bluish brown with seven red spots, three costal or subcostal, three on hind border, and one on the disc near the tip which is lurid and occupies the apical fourth of the tegmen: wings pale brown, red at the base. Body long 18 : exp. teg. 42 millims.

Reported from N. India, Almora N. W. P., Silhat.

29. Piryantostetha pudica, Walker.

O Cercopis pulica, Walker, Ins. Saunders. Hom. p. 84, (1858).

Phymutosterlata pulica, Butler, Cist. Ent. i. p. 269, (1874).

Allied to $I^{\prime}$. signifera.

Reported from sillat.

30 . Phymatostetha signifera, Walker.

"Cercopis signifera, Walker, List IIom. B. M. iii. p. 655, (1851).

Tomaspis signifera, Stål, Of vers. Kong. Vet. Aka. Förh. p. 151, (1865).

I’hymatostetha signifera, Stål, l. c. p. 721, (1870): Butler, Cist. Ent. i. p. 270, (187.4).

Blackish : frous before the middle, lobes of the vertex, a median stripe on the thorax and anterior lateral margins, scutellum, almost third basal part of the tegmina, pectus, venter, and feet stramineous : the stramineous portim of the tegmina with three irregular brown spots; beyond these, two arched patches and a transverse patch and the apical 
limbus rufescent-testaceous, the transverse prteh sometimes confinent with one of the arched patches situate near the posterior margin : wings fuscescent, base itself sordidly stramineous : narrow bauls on venter, base and apex of tibiæ, black: abdomen above black-vinlaccons with small marginal spots and apex sordidly stramineons: femma with an obsolcte fusco-testaccous stripe. Body long 19 : cxp. teg. 4.6 millims.

Reported from E. India : the Indian Museum possesses specimens from the Khasiya hills.

\section{Phimatostetha dubitabilis, Walker.}

- Cercopis dubitabilis, Walker, List Hom. B. M. Suppt. p. 173, (1858).

Phymatostetha dubitabilis, Butler, Cist. Ent. i. p. 270, (1874).

Reddish testaccous, black beneath : heal palo testaceous, vertex black pesteriorly: prothornx black with a stripe on the dise and tho posterior and nutero-lateral margins, testaceous : sentellum black with a testaceous mark on the disc : abdomen above testaceons, posterior margins of the segments, red : tegmina red, testaceons towards the tijs, with a black stripe which extends obliquely from the hase to the milllle of the interior border, is notched on the hind horder, hehind which thero is a black streak, is connectud in front with an oblique black streak, and is nearly connected with a more exterior oblique black streak which is dilated and angulated exteriorly and has there a black streak in front and is connected with a black spot hindward, wings grey with brown borders. Legs reddish, anterior femora and tibix striped with black (Waller). Body long 14: exp. teg. 33 millims.

Reported from Hindustan.

\section{o 32 . Pirmatustetiin pudins, Walker.}

O Cercopis pudens, Walkor, List Hom. B. M. Sujpt. p. 17.t, (1858).

$\measuredangle$ Tomaspis pudens, Stảl, Ofvers. Kong. Vet. $\Lambda$ ka. l'ör h. p. 151, (1865).

Phymatostetha pudens, Stål, 1. c. p. 721, (1870) : Butler, Cist. Wnt. i. p. 270 $(18$ เ).

Weakly sanguineous, black beneath; apical part of froms, band on vertex fròm eye to eye, clypeus, rostrum, two small spots on anterior margin of thorax, scutellum, base itself of tegmina, and five spots forming two rows, on the middle of each tegmen, disc above of the abdomen, pectus, venter, and fect, black: lateral limbi of prestethinm and very narrow margins of venter, red : wings before the middle pale sanguineons, besoud the middle slightly infuscate : lateral margins of the anterior part of thorax slightly reflexed. Body long $20:$ exp. tey. 45 millims $q$.

Reported from Hindustan, Silhat: the Indian M useum possesses § specimen from Sikkim.

14 
33. Phymatostetha basiclata, Walker.

- Cercopis basiclava, Walker, List 1lom. B. M. Suppt. p. 172, (1858).

o Tomaspis larinia, Stål, Ofvers. Kong. Vet. Aka. Förh. p. 152, (1865).

ᄂ Phymatostetha basiclava, Stål, l. c. p. 721, (1870): Butler, Cist. Ent. i. p. 270, (1874).

Red or flavescent-testaceous : rostrum, two spots on vertex, two spots near anterior margin of thorax, apex of scutellum, a narrow, scmetimes obsolete, stripe on tegmina from the base to one-third of length through the mildle, abdomen above (except marginal spots and tip), peetus, and bands on the venter and feet, black : lateral limbi of prostethium, apiees of coxæ and femora, yellow-testaceous : wings fuscescent, red at the base. Closely allied to preceding. Body long, 22 : exp. teg. 52 millims. $\$$.

Reported from India : the Indian Museum possesses a specimen.

034 . Phymatostetha binotata, Distant.

Phymatostetha binotata, Distant, Trans. Ent. Soc. p. 323, (1878).

Piceous : head, face, lateral margins of prothorax, borders of tegmina and two rounded spots on the same (one placed a little above the claval suture, abont one-third from the base, and the other midway, about onethird from the apex), pale sanguineous: scutellum black, narrowly bordered with red : abdomen, above, shining purplish black: eyes, legs, and body below black: wings fuseescent, narrowly sanguineous at the base (Distant). Long body 14 : exp. teg. 35 millims.

Reported from Sadiya (Assam):

\section{- Genus Callitettix, Stål.}

Ofvers. Kong. Vet. Aka. Förh. p. 152, (1865): Hem. Afric. iv. p. 55, (1866).

Body elongate: frons variable in form: lateral margins of the anterior portion of the thorax straight, longer than those of the posterior portion: sentellum somewhat longer than broad: tegmina oblong or elongate, gradually somewhat amplified towards the apex : feet long, posterior tibia unispinose.

\section{C) 35. Callitettix melanochra, Stål.}

Callitettix melanochra, Stål, Ofvers. Kong. Vet. Aka. Förh. p. 152, (1865).

Lnteseent, finely punetured : apical third of tegmina, apices of femora, anterior tibire (except the base), apieal half of posterior tibiro and tarsi, black : wings sordidly vinaceous : frons seen from the side produeed downwards in a right angle furnished with a ridge continned from the base to the middle: wings sordidly vinaceous. Body long $8: \exp$. teg. 24 millims. ठ.

Reported from E. India. 


\section{- 36. Callitettix producta, Stål.}

Callitettix producta, Stål, Ofvers. Kong. Vet. Aka. Förh. p. 153, (1865).

Black, very finely punctured; apex of scutellum, the tegmina, abdomen, and feet, reddish testaceous : frons tumid, forming a nearly straight angle, rounded at apex, without a keel : thorax hardly broader than long, lateral margins of fore part a little shorter than the anterior margin : tegmina narrow, slightly amplified towards the apex. Body long 7 : exp. teg. 16 millims. $\%$.

Reported from E. India.

\section{37. Callitettix versicolor, Fabr.}

- Cicuda versicolor, Fabricius, Ent. Syst. iv. p. 50, (1794) : Syst. Rhyn. p. 69, (1803).

Callitettiv versicolor, Stal, IIom. Fabr. ii. p. 11, (1869).

Black shining, fuscous-pubescent; tegmina with a spot before the middle of the clavus and a subtransverse spot on the corium placed between the middle of the corium and the base, white; two spots behind the middle of the corium, the external large, transverse; the internal small, obsolete, placed at the apex of the clavus, sanguincous : wings uncoloured, apical margin slightly infuscate. Body long with the tegmina 1] $\frac{1}{2}-12 \frac{1}{2}$ : breadth of pronotum $3-3 \frac{1}{2}$ millims. ㅇ.

Reported from Tranquebar.

\section{- Subfamily Aprirornorina, Stảl.}

OAphrophorida, Stảl, Hem. Afric. iv. p. 55, 66 (1866): Aphrophorina, Stäl, Ofvers. Kong. Vet. Aka. Förh. p. 722, (1870) : Scott. E. M. M. vii. p. 241, (1871).

Anterior margin of thorax round or angular, eyes usually transverse; scutellum flat, triangular.

\section{- Genus Ptrelus, St. Fargeau \& Serville.}

Body very large : head somewhat narrower than the thorax or of the same breadth, short, anteriorly obtusely and roundly subangulated, entire anterior margin obtuse ; frons slightly convex, transversely obsoletely sulcated, clypeus not extending beyond the apex of the anterior coxæ : ocelli almost equally distaut from each other and from the eyes or a little more distant: thorax finely rugose, quadrangular, anterior margin broadly rounded: scutellum longer than broad: tegmina subcultriform, narrowed towards the apex, very densely punctured : apical area of wing behind the second anastomosis posteriorly acuminate, not reaching the intramarginal vein : posterior tibiæ bispinose. 
1 have not transeribed the deseriptions of the following species attributed to Ptyelus by $\mathrm{Mr}$. Walker as it is very doubtful whether they would be considered as belonging to it now and no representatives apparently exist in the collection of the Indian Museum.

38. Ptrkilus conifer, Walker.

Ptyelus conifer, Walker, List. Hom. B. M. iii. p. 711, (1851).

Body long 6 : exp. teg. 17 millims. Reported from N. India.

39. Ptrelus quadridens, Walker.

Ptyelus quadridens, Walker, List Hom. B. M. iii. p. 711, (1851).

Body long 8 : exp. teg. 17 millims. Reported from N. India, N. Bengal.

40. Pryelus sexvittatus, Walker.

Ptyelus sewvittatus, Walker, List Hom. B. M. iii. p. 715, (1851).

Body long $5 \frac{1}{2}$ : exp. teg. $12 \frac{1}{3}$ millims. Reported from N. India.

-41. Pryelus puncrum, Walker.

Ptyelus punctum, Walker, List. Hom. B. M. iii. p. 718, (1851).

Body long $5 \frac{1}{2}$ : exp. teg. 12 millims. Reported from N. Bengal.

D 42. Ptyelus subrasciatus, Walker.

Ptyclus subfasciatus, Walker, List. Hom. B. Mr. iii. p. 724, (1851).

Body long 4 : exp. teg. 8 millims. Reported from N. India.

0 Genus Aphrophora, Germar.

Mag. Ent. iv. p. 50, (1821) : Amyot and Serville, Hist. Nat. Ins. Hém. p. 563, (1843) : Sccott, L. M. II. vii. p. 271, (1870) : Fieber, Kov. Mag. Zool. (3 Sér.) iii. p. $382,(1875)$.

Head almost as broad as the prothorax : vertex almost horizontal and somewliat flattened; anterior margin sometimes rounded, generally very obtusely angulated: elypens of variable length, reaching to or beyond the first pair of coxæ : rostrum long, $2-3$ jointed; ocelli two or sometimes absent; when present placed near the posterior margin of the vertex and more or less remote from the eyes. Pronotum hexagonal or trapezoidal with a longitudinal keel continued through the vertex; anterior margin rounded or obtusely angulated, posterior margin frequently deeply angulate-emarginate, scutellum triangular, shorter than the thorax. Tegmina slightly coriaceous, ovally elongate, acuminate : wings with the inferior nerve furcate from the base or before the midlle. Posterior tibia armed with $1-2$ spines and a circlet of spinnles at the tip. 
- 43. Apmropiora sigrhifera, Walker.

Aphrophora sigillifera, Walker, List Hom. B. M. iii. p. 700, (1851),

Testaceous shining: head and thorax flat, with a slight yellow keel rudely punctured, thinly covered with tawny down : head above short mostly pitchy, slightly concave on the posterior margin, rather more convex in front; its length less than one-fourth of its breadth; face ferruginous, partly pitchy, slightly convex, with a very narrow yellow stripe which is most distinct towards the epistoma and is there traversed by two slightly curved jellow bands, one large, the other shorter and narrower ; on each side, are about ten oblique, slightly curved transverse ridges: rostrum ferruginous with a pitchy tip: pectus with a short, broad, black band between the fore and middle legs: abdomen luteous, reddish on each side and beneatlı : legs ferruginons, spotted with yellow, lind femora yellow: tegmina lnrid, thickly punctured, narrow and conical towards the tips which are almost acuminate, brownish along part of the fore-border, on each side of a large subquadrate whitish spot which is in the middle : wings almost colourless, veins black, tawny at the base (Waller). Borly long 7: wings long 15 millims.

Reported from N. India.

Genus Clovia, Stål.

Hem. Afric. iv. p. 68, 75 (1866) : Ofvers. Kong. Vet. Aka. Förh. p. 723, (1870).

Head as broad as the thorax, rounded or roundly subangulated, varying in length, above flat, anterior margin of the lobes of the vertex acute, not furrowed ; frons somewhat convex, elypeus moderately produced at the apex, not extending beyond the apex of the anterior coxæ: position of ocelli variable : thorax sexangular with the anterior lateral margins usually very short, parallel or very slightly diverging backwards, scutellum longer than broad: tegmina with the commissural margin beyond the apex of the clavus subangulated or a little rounded: posterior tibiæ bispinose (Stål).

- 44. Crovia guttifer, Walker.

O Ptyelus guttifer, Walker, List Hom. B. M. iii. p. 712, (1851).

Cloria guttifer, Stal, Ilem. Afric. iv. p. 75, (1866).

Lurid : head and thorax flat, finely punctured, thickly tawny pubeseent; head with a short yellow band and two blask dots on fore-border; face ycllow, with a flat, middle stripe, on each side of which are nine oblique very shallow ridges, spaces between them tawny ; rostrum tawny with a black tip; abdomen luteous, pectus and legs yellow : tips of tho spines and feet pitchy: tegmina ferruginous, thickly covered with tawny 
down, with two oblique whitish stripes on the fore-border near the tip where there is a black dot; first stripe broad, seeond very small, a black dot on the hind-border near the tip and a fow whitish streaks along the veins: wings colourless, veins black, tawny towards tho baso. Body long $6 \frac{1}{2}$ : exp. teg. 15 millims.

Reported fron N. Bengal.

(2) 45. Clovia nebolosa, Fabricius.

- Cercopis nebulosa, Fabr., Syst. Ent. iv. p. 50, no. 14, (1794) : Syst. Rhyn. p. 94, (1803).

Clovia nebulosa, Stål, Hem. Fabr. ii. p. 16, (1869).

Very pale yellowish-grey: two small median black spots on the head : tegmina obscurely fuseous, a very oblique anterior band, a somewhat large median spot varied with fuscous at the commissure, an obliquely transverse spot behind the middle of the costal margin and a minute costal spot towards the apex, yellowish grey : two narrow median stripes abbreviated before the middle and a lateral subtriangular spot on the thorax also lateral limbus of seutellum, fuseescent. Long with tegmina, 10; breadth of pronotum 3 millims.

Reported from L. India.

\section{Genus Carystus, StåI.}

Berlin Ent. Zeitschr., vi. p. 303 (1862) : Hem. Afric. iv. p. 69, 81 (1866).

Head as broad or almost as broad as the thorax, obtusely angulated; Iobes of the vertex transversely impressed at the apex or furnished with $a$ transverse ridge near the apex; frons slightly convex : rostrum short : thorax quadrangular or sexangular, in the latter ease anterior lateral margins short: scutellum long, much longer than broad: tegmina membranous, pellucid, margined at the apex, obliquely roundly subtruncate at the apex : posterior tibiæ bispinose, upper spine sometimes very minute.

\section{$\checkmark 0$ 46. Carystus viridicans, StåI.}

Ptyelus viridicans, Stål, Ofvers. Kong. Vet. Aka. Förh. p. 251 (1854) : Freg. Eug. resa, Hem. p. 286 (1859).' (1877).

Carystus viridicans, Spangberg, Ofvers. Kong. Vet, Aka. Förh. No. 9, p. 13

Weakly olive-green, below with the feet still weaker: vertex and thorax anteriorly weakly rufous-testaceous : tegmina olive-yellow, hyaline: spines of the posterior feet black at the apex.

liody long 5 : breadth of pronotum 2 millims. Reported from Java Malacea, Singapore, Tenasserim (?) 
$\sqrt{0}$ Subfamily Macherotina, Stål.
$\sqrt{0}$ Mrachcrotida, Stål, Hem. Afric. iv. p, 55 (1866) : 'Macherotina, Stål, Ofvers. Kong. Vet. Aka. Förh. p. 727 (1870).

Anterior margin of thorax round or angular, eyes usually transverse : scutellum much elevated, compressed posteriorly, furnished with a long apical spine.

\section{$\checkmark$ Genus Machærota, Burmeister.}

Handb. Ent. ii. (i) p. 128 (1835).

Head small, frons tumid, confluent with the vertex, furrowed in tho middle, elevated at the posterior margin, bearing the two ocelli which aro approximate: basal joints of antennæ large, terminal setæ long, fine, curved: pronotmm septangular, arcuate: scutellnm larger, produeed backwards with a median longitudinal groove which is continued into a long, pointed, acute upwardly, curved downwardly, sabre-like process : tegmina hyaline, with seven cells at the apex and a large middle cell surrounded by a forked vein : legs simple, hinder tibiæ and two first joints of the tarsi with a circlet of spinules.

\section{47. Machærota ensifera, Burmeister.}

MLacherota ensifera, Burm. Handb. ii. i. p. 128 (1835) : Walker, List Hom. B. M. iii, p. 729 (1851) : Stål, Ofvers. Kong. Vet. Aka. Förh. p. 727 (1870): Signoret, A. S. E. F. (5 Sér.), ix, p. xlviii. (1879).

Light yellow with the second and third segments above, the median part of the frons, a space on each side of the metanotum and the origin of the process, black: tegmina and wings hyaline, the base of the tegmina and the claval portion of the wings, fuscous: tegmina with five apical cells of which three lie towards the margin; above these, which gradnally diminish in size, is a row of lyaline dots, on the margin itself : there are five brownish streaks on the prothorax of which the two median lateral ones are continued on the metanotum. Long 4 millims. ơ.

Reported from Philippines, Silhat.

J 48. Macherota spangbergi, Signoret.

Machcerota spangbergi, Signoret, A. S. E. F. (5 Sér.), ix, p. xlviii. (1879).

Yellowish brown; the median part of the frons, the tip of the abdomen above and the genital organs, black; feet brownisl, posterior tibin yellow with the tips black. Differs from $M$. ensiferc in having the frontal grooves black and the tegmina longer and less rounded at the tip. Long 4 millims. ㅇ. .

Reported from Silhat. 


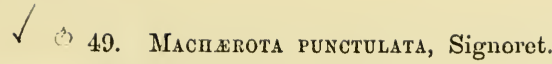

Macherota punctulata, Signoret, A. S. E. F. (5 Sér.), ix. p. xlix. (1879).

Brownish yellow, with the middle of the frons, the abdomen above (except the base), the feet (except the posterior tibio), and the frontal grooves, black; several transverse black spots on the thorax which is very finely punctured: metanotum brownish with two yellow, lateral, basal spots, the tip and the process blackish : tegmina elongate, five-celled and above the marginal two to three others smaller, very distinct : the hyaline nervures are spotted with several brown dots. Long 4 millims. ㅇ.

Reported from Silhat.

Note. OCosmopsaltria abdulla, Distant, noticed as No. 57 at page 226 of tho Jonrnal for $188+$ is the same as Cosmopsaltria spinosa, Fabricius, No. 59. Tho Indian Museum possesses a specimen of ${ }^{\emptyset}$ osmoscarta siamensis, Butler, bat the locality being uncertain, it has not been entered here. 

Notes on Indiun Rhynchota, No. 3.-By E. T. Aтrinson, B. A.

[Received Juno 15th ;-Read July 1st, 1885.]

[The notes are taken as far as possible from the original descriptions, most of which are practically unprocurable by observers in India, or from Stăl, Signoret, Butler, or Distant \&c. where these authors havo redescribed a species : the measurements of specimens not in the Indian Inseum lave been converted into millimetres from the recorded measurements of the several authors.]

The insects belonging to this section have been so little worked in India that the collector may feel sure of a rich harvest of new species. At the same time, we may take warning from the confusion in the results of the investigations into the European forms how very necessary it is, from the similarity in appearance and small size of the great majority of the species, to use the microscope more freely than has apparently hitherto been the practice in ascertaining the generic characters. We must wait some time before we can usefully attempt to do more than collect, compare, and fix the locality for the new forms of Nembracila and Jassidee which exist in such profusion in this country. In the meantime, these notes summarising what has been done in, as near as possible, the words of the authors, is a contribution to the work.

\section{Family Menbracide, Stål.}

Snbfam. Membracida, Stål, Hem. Afric. iv. p. 83 (1866): Fieber, Rev. Mrag. Zool. (3 sér.) iii. p. 332 (1S75).

\section{$\therefore$ Subfamily Centrotina, Stål.}

${ }^{3}$ Centrotida, Stål, Hem. Afric. iv. p. 83: Ofvers. K. V.-A. Förh. p. 280 (1869): Centrotina, ibid. p. 727 (1870).

Scutellum distinct, produced backwards behind the metanotum, very often sinnated at the apex and furnished with acute apical angles. The scutellum is wanting in Oxyrhachis, which in Hem. Afric. iv. p. 84 (1866) is placed by Stål in his subfamily Membracida (Membracina), and in Ofvers. Kong. Vet. Aka. Förl. p. 280 (1869) in his subfamily Centrotila (Centrotina) : in Hem. Fabr. ii. p. 47 (1869), it is again transferred to Membracina.

\section{Genus Oxyrhachis, Germar.}

Silbermann's Rev. Ent. iii. p. 232 (1835) : Fairmaire, A. S. E. F. (2 sér.) iv. p. 267 (1816) ; Stål, Ilem. Afric. iv. p. 84 (1866) ; Ofvers. K. V.-A. Förl. p. 280 (1869); Fieber, Rev. Mrag. Zool. (3 sér.) iii. p. 333 (1875).

Head perpendicular, frons a little elevated : thorax cornuted above the lateral angles, horns three-cornered; posterior process long, 
narrow, broad at the base, gradually narrowed, three-cornerer, reaching the interior margin of the tegmina; beneath, posteriorly compresslyamplified, furnished with a ridge continued thronghont the entirc thorax : tegmina with fire oblong, apical areas ; wings with thrce apical areas: sides of the pro- and meso-stethium armed with a small lobe or tooth : tibia dilated (Stål).

\section{Oxyrhacuis tarandus, Fabricins.}

Membracis tarandus, Fabr., Ent. Syst. Suppt. p. 514 (1798).

C) Centrotus tarandus, Fabr., Syst. Rhyng. p. 19 (1803).

Oxyrhachistarandus, Germar, in Silbermann's Rev. Ent. iii. p. 232 (1835) : Bnrmeister, Handb. Ent. ii. (i.) p. 133 (1835) : Amyot and Serville, Iist. Nat. Ins. Hém. p. $536(18+3)$ : Fairmaire, A. S. E. F. (2 sér.) iv. p. 268 (1846), t. 4. f. 13 : Walker, List Ilom. B. M. ii. p. 503 (1851) : Stål, Hom: A fric. iv. p. 81. (1866) : IIem. Fabr. ii, p. 47 (1869) : Fieber, Rev. MIng. Zool. (3 sér.) iv. 1’. 12 (187̄i).

Body olscure, dorsum fuscous; pronotum with two compressed horns, arched, obtuse, posteriorly subulate, longer than the abdomen ; tegmina hyaline, veins fuscous: wings white; feet ferruginous ( $F a b r$. ). Long 7-8; breadth of pronotum, 3 millims.

๖. Brown-red; + , reddish-yellow or russet; vertex usually russet, sometimes brownish, with two small callosities prolonged to the ocelli, the angles straight: head, or towards the base only, black : the pronotum with a red or russet-yellow median ridge running from the anterior margin, little defined, to the space between the lateral protuberances, thence defined and prolonged throughont the entire posterior process: lateral protuberances of the pronotum turning outwards and backwards and sometimes slightly upwards, a little compressed, varying in size, tip acute or obtuse : the posterior process reaching to or extending beyond the apex of the tegmina by about the fourth of its length, more or less recurved towards the apex, narrowly lanceolate in its posterior half with a median keel on the sides, its lower edge finely serrated: feet with sunken dots, ciliated and setiferous : tegmina sordid hyaline, the two corneous patehes at the base and the veins, russet-yellow (or fuscous-ferruginous): abdomen in the $\delta$, black; all the feet and the venter in the $q$, russet-yellow or reddish. Genitalia in the $\delta$, seen from above, transversely semioval ; seen from the side, trapezoidal, briefly truncated behind and directed obliquely towards the base, and forwards in a weak arch : anal styli yellow, projecting on the sides, widened almost into a lozenge-shape, on a short narrow pedicel: anal tube short, cylindrical, brown : genital plates placed one opposite the other, brown, gradually contracted together behind; their tip spatuliform, rounded and relieved: body whitish pubescent. 
․ Tast ventral areh olotusely emarginate: lateral plates (gatîe) broad, oval, acuminate behind; vagina (turière) straight, a little longer than tho gaîne; anal tubo eylindrical, extending beyond the tarière: abdomen russet yellow (Fiel., Stal.).

Reported from S. France, Egypt, Abyssinia, Senegal, Bengal. The Indian Museum possesses specimens from Calcutta.

\section{O 2. OxYriachis unicolor, Walker.}

' Oryrhachis unicolor, Walker, List Hom. B. M. ii. p. 509 (1851).

Piceous, densely fulvous pilose : head and pronotum thickly punctured : head transverse, not much broader than long, flat, slightly convex along the posterior margin, truncated in front, a little narrower than the pronotum between the shoulders, the pronotum ridged, rather low, rising vertically from the head, shoulders rounded, not prominent; horns above conical, prismatic, inelined forward, ascending, slightly diverging, their length equal to rather less than twice the breadth of the pronotum between them : posterior process ridged, reaching well beyond the tip of the abdomen, very slightly tapering from the base to the tip whieh is acute; very slightly undulating along the ridge; legs ferruginous; femora black; tilia dilated : tegmina almost without colour, long, narrow, lanceolate, punetured, ferruginous and partly tawny at the base; veins ferruginons, stout: wings colourless (Walker). Body long, 6 : wings, $14 \frac{1}{2}-15$ millims.

\section{G 3. Oxrrhachis RUdis, Walker.}

Osyrhachis rudis, Walker, List Hom. B. M. ii. p. 509 (1851).

Ferruginous : head piceous, transverse, flat, finely punctured, truncated and with a ferruginous spot on each side in front; not much broader than long, a little narrower than the pronotum between the shonlders; pronotnm itself very roughly punetured, slightly ridged, rising vertically from the head, with the shoulders rounded not prominent; horns above very broad, conieal, diverging, almost horizontal, slightly eurved, dise of the imer sicle slightly coneave towards the base; posterior side less than half the brealth of any other : posterior process keeled or ridged, extending well beyond the tip of the abdomen, tapering and slightly declining from the base to the midlle where it is deepened and keeled beneath and from thenee to the tip is serrated beneath and slightly inclined upwarls: tibice dilated; tegmina and wings colourless : tegmina narrow, lanceolate, with a small pale brown spot on the angle of the posterior border; veius thick, ferruginons; three discoidal areolas (IValler). Body long, 6-7: wings, 13-14. $\frac{1}{2}$ millins.

fieported from Indiat. 


\section{Oxyrhaciris subjecta, Walker.}

Oxyrhachis subjecta, Walker, List Hom. B. M. ii. p. 504 (1851).

Smaller than O. tarandus, the dorsal horns shorter in proportion and less diverging, posterior process more inclined upwards and not serrated bencatl. Black with a white pubescence : head transverse, subquadrate, flat, slightly impressed, fincly punctured, not much broader than long, a little narrower than the pronotum, truncated and ferruginons in front: pronotum somewhat elevated in front, rather ronghly punctured, rising almost vertically from the head with a ferruginous keel or ridge: shoulders of pronotum rounded, not prominent : horns above very broad, prismatic, conical, diverging, ascending, hardly curved downwards : posterior side much the shortest of all the sides; length of the horns rather less than the breadth of the pronotum between them: postcrior process mostly ferruginons, reaching well beyond the tip of the abdomen, inclined upwards, and ridged bencath, but not serrated from the middlo to the tip: pectus and abdomen whitish pubescent: legs red; tibiro dilated : wings colourless : tegmina tawny, punctured at the base and with a brown spot on the angle of the posterior border ; veins stout, ferruginous, four discoidal areolas (Walker). Body long 6 ; wings, il $\frac{1}{2}$ millims.

Reported from India.

In 0 . tarandus, the pronotum is elevated in front, the posterior process is ridged and also serrated beneath, the length of the horns is rather more than twice the breadth of the pronotum between them, and there are four discoidal areas: in $O$. subjecta, the posterior process is not serrated beneath and the length of the horns is rather less than the breadth of the pronotum between them, otherwise as in Otarantus : in O. uni-

- color, the pronotum is rather low in front and the length of the liorns is as in ${ }^{\prime}$ O. subjecta: in 0 . rutlis, the posterior process is keeled and serrated but there are only three discoidal areas.

\section{Species of uncertain position.}

5. Membracis fuscata, Fabricins.

Membracis fuscata, Fabr., Syst. Rhyng. p. 9, (1803); Fairmaire, A. S. E. F. (2 sér.), iv. p. 247, (1846).

Thorax foliaceous, rounded, fuscous; streak before the anterior margin and posterior band, white $(F a b r$.). This species does not seem to have been rediscovered since it was deseribed by Fabricius. Reported from India. 


\section{- Gemus Hrpsadcinenia, Germar.}

Silber. Rev. Ent. iii. p. 231 (1835) : Am. \& Serv., Hist. Nat. Ins. Hém. p. 535 (1813); P'tirnairo, A. S. L. F. (2 sér.) iv. p. 520 (1846); Stål, Hem. Afric. iv. p. 86 (1866) ; Ofvers. K. V.-A. Förll. p. 280 (1869).

Heal almost triangular, trilobed at the extremity : prothorax a little shorter than the togmina, without lateral horns, produced upwards in a compressed horn which is usually curved backwards and is bilobed at the tip : posterior process unilobed, slender, narrow at the base, narrower than the scutellum : tegmina free, slightly emarginate, extending much beyont the apex of the abdomen, very obliquely truncated at the apex, apical angle produced for some distance; tibio simple.

\section{Hypsadchenia dncinata, Stål.}

Iypsauchenia uncinata, Stâl, Ofvers. K. V.-A. Förh. p. 283 (1869).

Obscurely ferruginous, ochraceous pubescent: dorsal horn of the pronotum bending a little forwards, posteriorly sublobate, acuminate and recurved at the apex; tegmina punctured before the middle, pellucid behind the middle. 9 , long, 8 ; broad $2 \frac{1}{2}$ millims.

Reported from N. E. Iudia : the Indian Museum possesses a specimen (mutilated) from the Nága hills.

The anterior horn is much shorter and differently formed from other species of this genus : pronotum punctulate, furnished anteriorly witl a compressed dersal horn, somewhat shorter than the posterior process, bending a little forwards, posteriorly roundly amplified a little above the midlle, apex slender, acuminate and much recurved; posterior process somewhat clevated behind the middle : tegmina fairly densely reticulated behind the middle (Stål).

\section{Urisadcilenia hardwickir, Kirby.}

\section{Centrotus hardwickii, Kirby, Mag. N. II. ii. p. 21, f. 5 b (18?9).}

Hypsauchenic hardwickii, Fairmaire, A. S. E. F. (2 sér.) iv. p. 520, t. 3, f. 20, 21 (1846); Walker, List Hom. B. Mr. ii. p. 631 (1851); J. L. S. Zool. x, p. 183 (1867).

Brownish black, sprinkled with short, decumbent, inconspicuous hairs; legs (except the femora) paler than the rest of the body : pronotum minutely punctured, elevated above the head into a recurved quadrangular horn and terminating in a fork resembling a pair of concavoconvex, pedunculated, pointed leaves; scutellum (posterior process) of the length of the body, punctured, acute and elevated into a rounded lobe, near the apex : tegmina naked, punctured, veined longitudinally (Kirby). Bocly long, 7-9 millims.

Reported from Nepál : the Indian Museum possesses specimens from Sikkim and Assam. 
The ${ }^{\circ}$ IIypsanchenia ballista of Germar (Silb. Rev. Ent. iii. p. 231. 1835) nee Am. \& Serv. (Hist. Nat. Ins. Hém. p. 535, t. 9, f. 5, 18.13) is referred to $I H$. hardwickii by Fairmaire (l. c. p. 520) and Am. \& Serv.'s species $I$. balista is referred to the genus Sphongophorus fron Mexico (l. c. p. 261). ${ }^{\circ}$ S. balista, Am. and Serv., differs from H. ballista, Germar, in the posterior process ending in an erect ensiform prolongation, which is wanting in hardwicliii from India.

\section{${ }^{0}$ Genus Leptobelus, Stål.}

Hem. Afric. iv. p. 86 (1866) : Ofvers. K. V.-A., Förh. p. 280 (1869).

Frons without a basal lateral lobe, gradually narrowed : sides of the pectus unarmed: thorax with the disc elevated, the elevated part furnished on both sides with a slender horn, and posteriorly with a slender process, well apart from the body : scutellum clongate, longer than broad, gradually acuminated or much narrowed towards the apex, and with the apex slightly and narrowly obtusely or subsinuately truncated : exterior discoidal area of tegmina petiolated: wings with four apical areas: tibix very rarely dilated (Stål).

\section{Leptobelus dama, Germar.}

Centrotus dama, Germar, Silbermann's Rev. Ent. iii. p. 258 (1835) : Fairmaire, A. S. E. F. (2 sér.) iv. p. 510 (1846), t. 3, f. 14: Walker, List Hom. B. M. ii. p. 602 (1851).

Leptobelus dama, Stål, Berlin Ent. Zeitsch. p. 396 (1866) : Ofvers. K. V.-A. Förh. p. 284 (1869).

Black: thorax, posteriorly, with white scales; furnished with a short slender process on the dorsum anteriorly, turning upwards, armed at the apex on both sides with a spine which is procluced outwards, and inflexed at the apex : scutellum elongated, spinose, white at the base : extcrior discoidal area of corinm petiolated (Fairm.). Body long, 9 millims.

Reported from India: the Indian Museum posscsses a specimen from the Khasiya hills.

0 9. Leptobelus gazella, Fairmaire.

$\checkmark$ Centrotus gazella, Fairmaire, A. S. E. F. (2 sér.) iv. p. 510 (1816) : Walker, List Hom. B. M. ii. p. 602 (1851).

Leptobelus gazella, Stål, Berlin Ent. Zeitschr. x. p. 386 (1866) : Ofvers, K. V.-A. Förh. p. 284 (1869).

Cærulean black, thorax elevated in the middle, the elevated part trispinose, spines not inflexed, posteriorly not scaly with white. Closely allied to $L$. dama, from which it differs by its smaller size, the latcral spines shorter proportionately and slightly turned up : the prothorax is of 
a bluish blaek withont a white pateh posteriorly : the sentellum is clongated, white at the base : the tegmina are transparent, more yellow, blick at the base; exterior discoidal area of corium, petiolated. Borly long 8 millims.

Reported from India.

10. Leptobelus palimes, Stål.

Leptobelus pallipes, Stål, Ofvers. K. V.-A.Förh. p. 284 (1869).

Black, distinetly punctulate : thorax anteriorly without a dorsal process : sicles of thorax and peetus, also base of scutellum, densely ochreous-sericeous : tegmina sordidly vinaceous, base of clavus and entire costal area and radial area at the base and outwards beyond the middle, black, punctured: lateral horns of pronotum, slender, moderate, grarlually acuminated, straight, turning outwards, above unicarinate, beneath biearinate; posterior process slightly curved towards the base, thence straight, distant from the sentellum : exterior discoidal area of corium petiolated ; feet yellow-ferruginous. $q$ body long $5-5 \frac{1}{2}$ : breadth, 2 millims.

Reported from India.

Very like'L. curvispinus, Stål, (Ceylon), lateral horns of thorax shorter, more slender, turning outwards ; very little upwards; posterior. process not reaching the apex of the scutellum and the frous narrower at the apex (Stål).

Centrotus varius, Walker, List Hom. B. M. Suppt. p. 162 (1858).
Leptobelus varius, Stål, Ofvers. K. V.-A. Förh. p. 285 (1869).

Black, minutely punetured: head somewhat excavated between the eyes; pronotum keeled, nnarmed on each side, with a smooth shining spot on each side in front, shoulders somewhat aente: posterior process slender, acnte, undulating, testaceous in the middle, not extending beyond the tip of the abdomen : legs piceous : knees, tarsi and tips of the tibiw tawny : tegmina punctured towards the base, with various vitreous marks lindward, and with a large vitreous patch near the tip of the costa (Wullier.) Body long $4 \frac{1}{4}$ : exp. teg. $8 \frac{1}{2}$ millims.

Reported from Burma.

The species of this genus appear to be distributed as follows :-

A. Thorax furnished on the dorsum anteriorly with a short, slender process turning upwards and armed at the apex on both sides with a spine produced outwards, exterior discoidal area of corium petiolate ${ }^{\circ} L$. cluma,'L. gazella.

B. Thorax anteriorly without the dorsal process, either coruuted or ridged above the lateral angles. 
B. a. Posterior process of thorax distinetly cyrved towards the base : exterior discoidal area of corium petiolate: $L$. curvispinus, ${ }^{\circ} L$. pallipes.

B. $b$. Posterior process of thorax straight, subundate, reaching the apical part of the sentellum, disgoidal area of corium sessile, gradually much narrowed towards the base : L. varius, L. auriculatus, (Stål).

\section{Leptobelus scutellaris, Fabricius.}

- Centrotus scutellaris, Fabr., Syst. Rhyng. p. 19 (1803) : Germar, Silb. Rev. Ent. iii. p. 257 (1835): Fairmaire, A. S. E. F. (2 sér.) iv. p. 510 (1815) : Walker, List Hom. B. N. ii. p, 602 (1851).

Stål, in index to Hem. Fabr. (ii. p. 115), places a query after this species; and all that seems to be known is that it is reported from India.

\section{Leptobelus paria, Fairmaire.}

Centrotus paria, Fairmaire, A. S. E. F. (2 sér.) iv. p. 513 : (1846) : Walker, List Hom. B. M. ii. p. 609 (1851).

Ferruginous : eyes projecting : horns a little divaricate, slender, acute, compressed : posterior process very slender, bordered on each side by the seutellum which is broad and white, as long as the abdomen : sides of the pectus white: fect yellowish: tegmina transparent (Fairm.) Long 6 millims.

Reported from India.

0 Genus Xiphopæus, Stål.

IIem. Afric. iv. p. 87, 91 (1866); Ofvers. K. V.-A. Förh. p. 281 (1869).

Frons prominulous below in the shape of a tuberele; thorax cornuted above the lateral angles; posterior process much distant from the seutellum and abdomen, much eurved from the base or genieulated near the base ; beneatl, armed with small spines, at least towards the base, not dilated in the middle beneath; tegmina with five apical and two discoidal areas, none of which are petiolated: wings with fonr apical areas: tibiæ simple or very slightly dilated (Stål).

\section{XIPHOPEUS PILOSUS, Walker.}

Centrotus pilosus, Walker, List Hom. B. M. ii. p. 606 (1851).

Xiphopeus pilosus, Stål, Ofvers. K. V.-A. Förh. p. 285 (1869).

Ferruginous, very thickly clothed with sordid white down: head punctured, short, transversely subfusiform, a little narrower than the thorax, with a metallic lustre in front, nearly twice as broad as long: face small : thorax punctured, deep in front, partly black, rising almost vertically from the head, slightly ridged, shoulders obtusely angular, 
somewhat prominent: horns above rather long, broad, irregularly prismatic, slightly diverging and inclined forwarts; tips more diverging, almost trifureate, slightly amplified; inner side and outer side much broader than the hinder side, angles slightly serrated; of the three forks or angles at the tip, the fore one is slightly obtuse, the middle one acute, and the hind one rectangular; hind horn stont and vertical for a short space from the base, then forming a right angle and extending backward much beyond the tip of the abdomen; hind part tawny, slender, tapering, very slightly undulating, with an aente black tip : peetus and abdomen piceous : legs tawny : a brown spot on the hind angle of each tegmen: veins tawny, here and there, brown (Wulker). Borly long $4 \frac{1}{4}$ : exp. teg. $9 \frac{1}{2}$ millims.

Reported from N. India.

\section{Genus Acanthophyes, Stål.}

Шem. Afric. iv. p. 87, 89 (1866); Ofvers. K. V.-A. p. 281 (1869).

Thorax much elevated between the lateral angles, very often cornuted above the same angles; posterior process distant from the scutellum, bisinnate beneatl, more or less amplified or lobed in the middle, between tho sims, with the amplified part reaching the dorsum of the abclomen or the apex of the seutellum : tegmina with five apieal, two discoidal areas: wing's with four apical areas : tibiæ simple (Stål).

\section{(3) 15. Acanthophyes capra, Fabricius.}

h' Membracis capra, Fabr., Ent. Syst. Snppt. p. 514 (1798).

('Centrotus capra, Fabr., Syst. Rhyng. p. 20 (1803).

Acanthophyes capra, Stål, Hem. Fabr. ii. p. 50 (1869).

Borly altogether fuscons, immaculate : horns of thorax, large, thick, obtuse ; thorax posteriorly sliort, emarginate : tegmina fuscous (Fabr.). Ferruginous black or ferruginous, remotely flavescent-grey-sericeous, two sinall basal spots on scutellum and sides of peetus very densely sericeons : lateral horns of thorax depressed, truncated, bicarinate above. $\rho$ : long: with tegmina $6 \frac{1}{2}$; thorax broad, 3 ; exp. thoracic horns, $4 \frac{1}{2}$ millims.

Head between the eyes a little shorter than broad, heneath the eyes abruptly very much narrowed; frons gradually slightly narrowed, sub. truncate, freely produced downwards for a distance : tlorax punetured, armed on botl sides anteriorly above the lateral angles with a depressed horn, very slightly narrowed towards the apex, truneated at the apex, bicarinate above and below ; anterior apical angle of the horns round, posterior somewhat acute; posterior process distinetly carinate, very broadly sinuated in the middle above, a little amplified beneath in the middle, reaching the apex of the scutellum, very slightly decurved 
towards the apex : tegunina fuscous-ferruginous or ferruginous-grey, punctured at the base (Stål).

Reported from Tranquebar, India.

Genus Leptocentrus, Stål.

Hem. Afric. iv. p. 87, 90 (1866) : Ofvers. K. V.-A. Förh. p. 281 (1869).

Frons more or less prominulous downwards : thorax cornuted above the latcral angles ; posterior process, slender, three-cornered, acute, emitted a little before the posterior margin of the thorax, altogether distant from sentellum and abdomen, not unless posteriorly touching the interior margin of the tegmina, not sinuated beneath nor amplified in the middle : scutcllnm emarginate at the apex, moderate : tegmina with five apical, two discoidal areas, none of them petiolated: wings with four apical areas : tibiw simple.

\section{O 16. Leptocentrus taurus, Fabricius.}

7 Membracis taurus, Fabr., Syst. Fint. p. 676 (1775) : Spee. Ins. ii. p. 317 (1781): Mant. Ins. ii. p. 24t (1787) : Ent. Syst. iv. p. 14 (179t); Olivier, Enc. Méth. vii. p. 605 (1792).

(J) Membracis rupicapra, Fabr., Ent. Syst. Suppt. p. 51t (1798).

c) Centrotus rupicapra, Fabr., Syst. Rhyng. p. 18 (1803).

i. Centrotus tuurus, Fabr., Syst. Rhyng. p. 20 (1803); Germar, Mag. iv. p. 32 (1821) ; Silb. Rev. Ent. iii. p. 257 (1835) : Fairmaire, A. S. E. F. (2 sér.) iv. p. 510 (1846) ; Walker, List Hom. B. M. ii. p. 602 (1851); ibid. Suppt.p. 158 (1858); J. Linn. S. Zool. i. p. 93 (1856) ; ibid. p. 163 (1857).

IIembracis tricornis, Hardwicke, Zool. Journ. iv. p. 11.t, t. Suppt. 30, fig. c. d. f. (1828).

$G$ Centrotus terminalis, Walker, List Hom. B. M. ii. p. 604 (1851).

Centrotus vicarius, Walker, l. e. p. 605 (1851).

Leptocentrues taurus, Stål, Ofvers. K. V.-A. Förh. p. 491 (1862); Berlin Ent. Zeitsch. x. p. 386 (1866) : Hem. Fabr. ii. p. 50 (1869).

Fairmaire makes $M$. tricornis, Hardwicke, a synonym for $\overleftarrow{L}$. taurus, Fabr., to which Walker adds his own $C$. vicarius and $C$. terminalis, and Stål adds" C. rupicapra, Fabr.

Head fuscous, eyes castaneous, a white spot before the cyes : thorax fuscous with two stout horns, a little arehed, produced posteriorly, filiform : sides of pectus white : wings obscure : bolly fuseous (MI. taurus, Fabr.). Body small, fuscons; thorax with three horns, the lateral thicker, obtuse or rather truncate, subdentate ; the intermerliate, posterior, recurved: tegmina fuscous hyaline; wings whitish (M. rulpicup)ra, Fabr.). Fairmaire remarks that $C$. taurus is black with the scntellum and sicles of the pectus white and the tegmina with the costa fuscous. Hardwicke describes his $M$. tricornis as head, thorax, and body black; 
wings ash-grey, longer and broaler than the body, and ineumbent: thorax three-homed, two of which are placed in front behind the eyes, about as long as the thomx, strong, erect and enrved outwards; the third horn rises from the posterior margin of the thorax, extending in a gentle arch the whole length of the body and tapering to the apex. Stanl notes that the type has the lateral margins and apical spine of the sentellum sordid whitish. Walker's $C$. terminalis is thus deseribed: "Black, elothed with tawny hair's; head and pronotum roughly punetured: head convex very short, transversely subfusiform, a little narrower than the pronotum, nndulating along the hind border, retuse in front, on each side of the face whose hind border is semieirenlar and oceupies much less than half the length of the face; clypeus prominent, retuse : pronotum thiek in front rising vertically above the head, indistinetly ridged ; shoulders very obtusely angular, not prominent; above them are two long, stont, prismatie, diverging, acute horns which are curved backwards, especially towards the tips; their sides are slightly concave, their inner and outer siles are of equal breadth, their hinder side is narrower; behind them the pronotum is armed with a long, slender, smooth, acute triangular horn which is slightly eurved downwards and extends to the tip of the ablomen: abdomen above with hoary reflections : tibir pitehy; hind tursi tawny : wings very pale lurid; a narrow pale brown streak on the fore-border near the tip of each tegmen; two discoidal areolas; veins tawny: wings colourless, veins black." Body long 6-8 millims.

Fairmaire notes that he cannot separate from this speeies smaller ones of which the horns are very acuminate and hardly recurved, and others in which the horns are relieved and oblique. MI. vicarius, Wal$\mathrm{ker}$, is one of those in whieh the horns are short.

Reported from India: the Indian Museum possesses specimens from Calentta, Siklim.

\section{¿) 17. Liptocentrus reponens, Walker.}

¿Centrotus reponens, Walker, List Hom. B. M. ii. p. 604 (1851) : J. L. S. Zool. x. p. $183,(1867)$.

Centrotus untilope, Stảl, Freg. Eug. Resa, Ins. p. 281 (1859).

Leptocentrus untilope, Stål, Ofvers. K. V.-A. Förlı. p. 727 (1870).

Fuseous ferrnginous: rudely punetured, sparingly covered with whitish down, heal and thorax anteriorly more densely clothed; thorax anteriorly subreclinately sloped, armed on both sides with a horn, strong, long, prodnced somewhat upwards, reeurved towarils the apex, three-coruered; posterior proeess from its base distant from the abdomen, somewhat eurved at the base, thence straight, equally thick, extending somewhat beyond the apex of the abdomen, three cornered 
with a ligh median ridge: tegmina weakly fuscescent-hyaline, reins fuscous. Size almost the same as that of $L$. tauru, but differs in being longer, proportionately narrower, anterior horns longer, more produced upwards, scutellum concolorous (Stål). Body long 9: broad 5 millims.

Reported from New Guinea, Timor, Philippines, Ceylon, India : the Indian Museum possesses specimens from Calcutta.

C 18. Leptocentrus substitutus, Walker.

- Centrotus substitutus, Walker, List Hom. B. M. ii. p. 605 (1881).

In structure like the preceding : horns of thorax short as in var. vicarius, Walker, of $L$. taurus; pectus with a thick pateh of pale yellow down on each side in front; legs black ; tarsi pitehy; hind tarsi tawny ; wings black; tips colourless; veins tawny. Body long $6 \frac{1}{4}$ : wings long $12 \frac{1}{2}$ millinıs. (Walker).

Reported from N. Bengal.

\section{Genus Centrotypus, Stål.}

Hem. Afric. iv. p. 88 (1866) : Ofvers. K. V.-A. Förh. p. 281 (1869).

Frons gradually narrowed from the base, without a lobe on both sides at the base: posterior process of thorax not sinuated on each side from the base to the scutellum, never distant from the scutellum, gradually narrowed, covering the whole or almost the whole of the scntellum; dorsum of thorax distinetly keeled, the keel not (or very obsoletely) continued forward through the thorax, which instead of a keel lias a somewhat smooth line : sides of scutellum not prominulous, sentellum not or only a little, seldom twice, as broad as the base of the posterior process of the thorax : tegmina with five entire, oblong, apical arens; costal area punetured at the base, costal and radial areas abbreviated at the same distance or almost so from the base (Stål).

O 19. Centrotypus flexuosus, Fabricins.

O Membracis flexuosa, Fabr., Ent. Syst. iv. p. 12 (1794).

Centrotus flexuosus, Fabr., Syst. Rhyng. p. 18 (1803) : Fairmairc, A. S. E. F. (2 sér.) iv. p. 516 (1846) : Walker List Hom. B. M. ii. p. 611 (1851).

O Centrotus anchorago, Guérin, Icon. Règne Anim. t. 59, f. 4 (1829-43).

Centrotypus flexuosus, Stål, Hem. Fabr. ii. p. 51 (1869) : Ofvers. K. V.-A. Förh. p. 286 (1869).

Thorax punctured, cœrulean; with a stout horn on both sides, flat, acute, black, a little flexuose, posteriorly produced in a spine, longer than the abdomen : wings black, a spot on the slender margin whitish : body black 'MI. flexuosa, Fabr.). 
Corulean black : lateral horns of thorax long, somewhat recurved, scarcely turning npwards, above unicarinate, hardly broader than the median part of the posterior process, acute : tegmina subvinaceous, ferruginous towards the apex, with the base and the broad costal limbus beyond the middle, blackish (Stål) \&. Body long 10 : breadth of pronotum $3 \frac{3}{4}$ : exp. horns of thorax $8 \frac{1}{2}$ millims.

Reported from India: the Indian Museum possesses specimens from Sikkim.

\section{Centrotypus assamensis, Fairmaire.}

Centrotus assamensis, Fairmaire, A. S E. F. (2 sér.) iv. p. 517 (1846).

C Centrotus costalis, Walker, Ins. Saunders. Hom. p. 27 (1858).

Centrotyjus assumensis, Stål, Ofvers. K. V.-A. Förh. p. 286 (1869): Distant, J. A. S. B. xlviii. (2), p. 38 (1879.

Greenish black, blue on the horns: allied to $C$. flexuosus, Fabr. thoracic horns less dilated, ridged before and behind, more relieved: tegmina yellow, pellucid, with the external margin blackish brown, a brown patch at the internal angle (Fairm.). Long 11 millims.

Reported from Assam and Tenasserim; the Indian Museum possesses specimens from the latter locality.

\section{21. Centrotypus obesus, Fairmaire.}

Centrotus obesus, Fairmaire, A. S. E. F. (2 sér.) iv. p. 518 (1846) : Walker, List Hom. B. M. ii. p. 612 (1851) : Stål, Berlin Ent. Zeitsch. x. p. 386 (1866).

Centrotus malleator, Walker, List 1. c. p. 612 (1851), Java.

(7) Centrotus malleolus, Walker, List l. c. p. 613 (1851), Java.

1) Centrotus malleus, Walker, List 1. c. p. 613 (1851), Ceylon.

Centrotypus obesus, Stâl, Ofvers. K. V.-A. Förh. p. 286 (1869).

Cornlean-black, shining: prothorax tumid and rounded anteriorly and between the shoulders (especially in \&), deeply punctured : horns conical, slightly projecting, almost horizontal : posterior process, sinuated, slender, slightly curved below at the tip, longer than the abdomen : scutellum white, short; basal half of tegmina of a transparent yellow, rest brown, external border blackish (Fairm.). Long 8-10 millims.

Reported from Java, Ceylon, India.

\section{Genus Coccosterphus, Stål.}

Hem. Fabr. ii. p. 51 (1869).

Body small, obovate: head with the eyes equal in breadth to the anterior part of the thorax, with the eyes, deflexed, somewhat transverse, slightly inflexed beneath the eyes, frons a little elevated, not freely prominent, with the apical margin a little prominu- 
lous: ocelli twice as distant from each other as from the cyes: thorax moderately convex, unarmed on both sides anteriorly, gradually narrowed behind the slightly prominulous lateral angles and gradually passing into the posterior process; the posterior process entire on both sides at the base, not sinuated, gradually acuminated, straight, slightly deflexed at the apex, equalling the apex of clavis, somewhat highly ridged, much depressed in the middle. No complete scutellum: mesonotum furnished on both sides at the apex with a spinule turning backwards. Tegmina short, not extending beyond the apex of the abdomen, gradually somewhat amplified towards the apcx which is obliquely rounded, opaque and coriaceous at the base; exterior vein of clavus united with the commissure at some distance beyond the middle; corinm emitting the ulnar and radial veins from tho basc, uhuar vein somewhat forked before the middlo of the corium, two discoidal areolas or, if the areola behind the fork of the uluar vein bo included, three; the exterior discoidal areola stylated, stylus separating the interior (or intermediate) discoidal areola from the first apical arca, five apical areas. Wings with three apical areolas. Feet moderate, tibix prismatic, anterior a little depressed; anterior trochanter's marmed within.

A curions genus allied to Gargara, Stâl ; but very distinct in laving the thorax behind the lateral angles gradually passing into the posterior process which lias no sinus at the base; there is no produced complete scutellum, but the mesonotum is armed at the apex with two very distant spines (Stål).

\section{d22. Coccosterphos minutus, Fabricins.}

a DIembracis minuta, Fabricius, Ent. Syst. Suppt. p. 514 (1798).

7 Centrotus minutus, Fabricins, Syst. Rhyng. p. 22 (1803).

? Scaphula (?) minuta, Fairmaire, A. S. E. F. (2 sćr.) iv. p. 495 (1S46); Walker, List Ilom. B. M ii. p. 589 (1851).

Coccosterphus minutus, Stål, Hem. Fabr. ii. p. 51 (1869).

Minute : head and thorax black, scabrous with elevated dots: thorax subunarmed, produced posteriorly, attenuated, a little elevated before the apex, as long as the abdomen : tegmina obscurely whitish, somewhat spotted fuscous, black at the base ; wings shorter, liyaline : body black (Fabr.). Black, flavescent-greyish-sericeous: head, thorax and tegmina remotely sprinkled with somewhat large granules : thorax furnisherl with a ridge or keel, obsolete anteriorly, very elevated in the posterior process, in its medium depressed part interrupted: tegmina palcly greyishflavescent, subpellneid, obsoletely dotted with white, veins here and there infuscate, granules and almost third basal part, black; black part punctured; ulnar vcin rumning through this part greyish-flavescent (Stål).

ơ. Body long $3 \frac{1}{4}$ : broad 2 millims.

Reported from E. India, Tranquebar.

16 


\section{Subfamily Darnina, Stål.}

"Darnilla, Stâl, Ofvers. K. V.-A. p. 550 (1867); p. 250 (1869).

Genus Hemiptrycira, Germar (in part).

Fairmaire, $\Lambda$. S. E. F. (2 só́r.) iv. p. 312 (1846) : Stâl, Ofvers. K, V.-A. Förh. p. 557 ((1867), p. 250 (1869).

Thorax without an impression above the lateral angles, much elevated anteriorly, furnished on both sides with a long horn, strong, curved, acute, turning upwards, reaching with the lateral margins of the posterior proeess the longitudinal vein of the clavus, covering part of the apes of the clavus and narrow interior posterior part of the corium, apical half or more very slightly deflexed; entire dorsum tectiform or compressly acute, sinuated above beyond the middle, behind the sinns gradually decreasing in height, equal to or extending a littlo beyond the apex of the tegmina; head obtusely triangular : ocelli a little more distant from the eyes than from each other.

\section{C23. Немiptycha CRUx, Linnæus.}

Cicada crux, Linn., Syst. Nat. (ed. 10) i. p. 435 (1758) : Mras. Lud. UIr. p. 154 (1764).

Hemiptycha crux, Stål, Berlin Ent. Zeitsch. $x$, p. 389 (1866).

Fuscous-testaceous : thorax black, anteriorly obsoletely spinkled testaceons, behind the lateral horns broadly margined with yellow, this yellow margin narrowed backwards, extended beyond the middle of the posterior produced part : tegmina fuscous. Thorax distinetly punctulate, furnished with a very strong and long horn above the lateral angles, compresserl, turning ontwards and moderately upwards, at the apex obliquely truneated, anteriorly rounded, at the apex posteriorly acuminate, slightly amplified towards ұoч ally acuminated, extending a little beyond the tip of the tegmina; apex itself very slightly recurved: dorsum seen from the side somewhat straight and with a distinct ridge, lateral margins straight (Stål). + , body long 18; exp. horns of thorax 17 millims.

Reported from India (Linn.).

\section{Genus Scaphula, Fairmaire.}

A. S. E. F. (2 sér.) iv. p. 494 (1846).

Head triangular, rounded at the tip : eyes very broad, prominent, ocelli contiguous: prothorax smooth, sometimes elevated, slightly rounded posteriorly : tegmina free, with posterior veins waved, one small diseoidal; the internal extremity sometimes slightly covered by the prothorax : posterior tarsi longer than the anterior (Fuirm.). 
U 24. Scaphula semiatra, Fairmairc.

Scaphula semiatra, Fairmaire, A. S. E. F. ( 2 sér.) iv. p. 494 , t. iii. f. 18,$19 ; t$. vii, f. 20 (1846); Walker, List Hom. B. M. ii. p. 589 (1851).

Brownish black, shining; prothorax somewhat elevated in the middle, terminated posteriorly by a defined, rounded border; tegnina frec, dull black, posterior third transparent : abdomen beneath, anterior fect, knees, and tarsi yellowish; posterior feet blackish (Fairm.) Body long 6 millims.

Reported from Coromandel ?

\section{O Family JASsid 2 , Stål.}

OJassida, Stål, IIem. Afric. iv. p. 82 (1866) ; Fieber, Kat. p. 8 (1872); Rev. Mag. Zool. (3 sér.) iii., pp. 337, 386, (1875).

Lo Subfamily Parorina, Ficher.

D Paropida, Fiober, Kat. p. 7 (1872); Rev. Mag. Zool. (3 sér.) iii, p. 384 (1875) : Paropides, Sign. A. S. E. F. (5 sér.) ix, p. 47 (1879).

\section{$\checkmark$ OGenus Signoretia, Stål.}

Freg. Eng. Resa, p. 289 (1859).

Body elongate, subparallel : head with the eyes broader than the thorax, round in front, semilunated on the vertex, subeoncave, furnislied posteriorly with a high transverse ridge; frons large, convex, with a mnch elevated longitudinal ridge; ocelli placed in a small excavation in the margin of the base of the frons at the eyes : thorex shorter than broad, parallel, anteriorly semicireularly rounded and produced between the eyes, rounded belind, posteriorly convex, anteriorly semicircularly depressed, where it is furnished with two ridges before the apex, lying close to each other: scutellum small, triangular : tegmina longer than the abdomen with the longitudiual veins towards the apex, once joined by the transverse nervures, the intracostal longitudinal vein forked behind the middle : feet moderate, posterior tibia three-cornered, angles remotely spinose. Allied tboParopia: ocelli nearer the eyes, frons convex, ridged, thorax differing in shape, the suctellum very small (Stảl).

\section{$\checkmark$ O25. Signoretia malaya, Stål.}

OThamnotettix malaya, Stål, Ofvers. K. V.-A. Förlı. p. 192 (1855).

Signoretia malaya, Stål, Freg. Eug. Resa, p. 290, t. 4, f. 9, a. b. (1859).

Vireseent-whitisb, densely and roughly punetured ; tegmina virescent whitish hyaline; cutire clavus, space between the costa and the 18 
second longitudinal vein, also other veins on both sides, fairly roughly punetured (Stål). Long 7 ; broad, $1 \frac{1}{2}$ millims.

Reported from Malacea, Tenasserim (?).

$\checkmark$ O Subfamily Ledrina, Stål,

Ledrina, Stål, Ofvers. K. V.-A. Förh. p. 731 (1870) : Oscarida, Fiebor, Kat. p. 7, (1872) ; Rev. Mag. Zool. (3 sér.), iii, p. 386, (1875).

O26. Ledra serrulata, Fabricius.

Ledra serrulata, Fabr., Syst. Rhyng. p. 24 (1803) : Stảl, Hem. Fabr. ii, p. 58, (1809).

Greyish or flavescent-greyish : body beneath and feet weakly testaceous flavescent or testaceons whitish : tegmina greyish pellucid behind the middle, near the base with a pallescent, broad, obsolete band; wings sordidly hyaline : the dorsum of the abdomen flavescent-sanguineons : thorax elevated posteriorly and furnished on both sides with a lobe, ereet, produced forwards, erenulated posteriorly on the margin. Sometimes with two interrnpted bands on the inferior part of the head and certain median marks on the thorax, black (Stål). \& Body long, 18; broad 5 millims. Stature ofOL. aurita, Linn. (Britain) head more roundly produced, lobes of thorax longer. Head somewhat shorter than the thorax, gradually distinetly amplified throngh a short space before the eyes, thenee abruptly angulated and anteriorly much rounded, the ocellar tract impressed, the impressed part amplified forwards and gradually merging in the anterior dise, anteocular part remotely sprinkled with distinct granules. Lateral margins of thorax parallel at the apex, thence somewhat divergent backwards, two parallel ridges behind the middle anteriorly slightly divergent, obtuse, minutely tubereulate, and towards the siles a lobiform erest, very high, slightly bending forwards, remotely granulate, posteriorly erenulate. Scutellum gradually transversely depressed towards the middle, before the middle sprinkled with granules towards the sides, posteriorly mueh elevated, the elevated part posteriorly black and granulate. Tegmina gradually slightly amplified beyond the middle, thence rounded ontwards : almost cutire clavus and corium towards the base punctured and sprinkled with granules at intervals, veins here and there infuscate. Tibio above sparingly granulate.

Reported from Malacea, Tranquebar.

ro27. LEDRa mutica, Fabricins.

Ledra mutica, Fabricius, Syst. Rhyng. p. 25, (1803) : Stål, Hem. Fabr. ii, p. 59, (1869).

$\checkmark$ Ledra fornicata, Walker, List Hom. B. M. iii, p. 815, (1851). 
Greyish mingled with fuseous or weak ferruginous and granulated, beneath palely sordid flaveseent : head and thorax equal in length, tho head obtusely angulated at the apex, the thorax posteriorly quadricarinate : dorsum of abdomen weakly sanguineous : clavus sometimes marked anteriorly with a large pale spot : wings sordid hyaline, sanguincons at the base. $\$ 2$ fody long, 18; broad $4 \frac{3}{4}$ millins.

Allied toOL. dilatata, Walker, but narrower, head longer. Head very obtusely tectiform, much produced, furnished with a median wrinkle, rumning through it, and posteriorly with four longitudinal wrinkles, the exterior a little oblique ; somewhat roundly amplified before the eyes, thence gradually obtusely angulated towards the apex, gradually very obtusely roundly-narrowed, sprinkled with granules and small tubereles. Thorax hardly narrowed forwards, subsinuate before the middle on both sides, behind the middlo gradually clevaterl backwards, remotely sprinkled with gramules, posteriorly furnished with four parallel ridges. Scutellum with the apical part much elevated and longitudinally birngose, the wrinkles (rugo) granulated. Tegmina gradually a little amplified beyond the middle, thence rounded externally, behind the middle more pellucid, towards the base sprinkled at intervals with granules, greyish, veins more obscure, here and there infuseate or palely ferruginous. Tibio above sprinkled with some granules (Stảl).

Reported from Tranquebar, N. India, N. Bengal.

\section{Vo 28. Ledra dilatata, Walker.}

Ledra dilatata, Walker, List IIom. B. M. iii, p. 811, (1851) : Stål, Ofvers, K. V.• A. Förh. p. 495, (1862); IJem. Fabr. ii, p. 59, (1869).

$\checkmark 0$ Ledra scutellata, Walker, 1. c. p. 812, (1851).

$\checkmark$ C. Ledru plana, Walker, 1. c. p. 812, (1851).

Closely allied to L. mutica, Fabr. Testaceous, paler beneath : head and prothorax, with ferruginous tubereles: head broader than the thorax, very slightly arenated, anterior margin rounded, each side somewliat angulated, hinder margin very slightly sinuate, weakly tricarinate, the lateral ridges short and oblique ; its length hardly half its brealth : thorax convex on the dise, furrowed across, very slightly convex along the anterior margin, with a pale band on the dise, which has five slight ridges, the middle one short: posteriur margin coneave in the mildle, convex on each side : scutellum gibbous with two slight crests towards the tips: abdomen red above: tegmina whitish, very convex along the foreborders towards the tips; veins pale ferruginous with a few piceons tubereles towards the base: wings eolourless: tibir with piceous tubercles, slightly widened and fringed (Waller). Bolly long $10 \frac{1}{2}:$ teg. 25 millims.

Reported from E. India. 
O 29. Ledra dorsalis, Walker.

Ledra dorsalis, Walker, List Hom. B. M. iii, p. 810, (1851) ; Stål, Ofvers, K. V.A. Förh. p. 495, (1862).

Ferruginons, testaceous beneath, head a little broader than tho thorax: very slightly arehed, rounded in front, obtnsely angular on each side, slightly sinuate on the posterior margin; its length hardly lialf its breadth; three broad, low, rounded ridges on the vertex, tho side pair oblique; face with three black stripes corresponding to the ridges above : shield roughly punetured, slightly convex in front, very coneave on the hind border, armed with six erests, outer pair irregular, horizontal, and oblique ; next pair vertical, very high, marked with blaek, convex above, perpendicular and forming right angles behind; inner pair slight, interrnpted with two black dots on each towards the hind border, scutellum eonvex : abdominal appendages short : legs testaceous : tegmina ferruginous, tuberculate, especially towards the base, almost colourless towards the tips: wings almost colourless (Walker). Body long 21 ; teg. $37 \frac{1}{2}$ millims.

Reported from Silhat.

The following three species are of doubtful position :-

\section{$\checkmark 0$ 30. Ledra punctata, Walker.}

Ledra punctata, Walker, List Hom. B. M. iii, p. 824, (1851).

Testaceous, paler beneath : head and thorax broad, roughly punetured; head very short-conical, narrower than the thorax, not arehed, hardly ridged, very slightly eoneave along the hind border, with irregular whitish reticulations; its length less than half its breadth; face with a furrow along each side : shield green on the disc, with irregular whitish reticulations in front and on each side, where it is slightly widened and angular: legs pale testaceous : tegmina almost colourless, punetured from the base to the tips, tinged with pale green and along the borders with pale brown; tips darker brown; veins very few : wings white (Waller). Body long, $7 \frac{1}{4} ;$ teg. $15 \frac{1}{2}$ millims.

Reported from Malabar.

\section{$\checkmark$ O 31. Ledra lineata, Walker.}

Ledra lineata, Walker, List IIom. B. M. iii, p. 830 (1851).

Stramineous, fusiform : head and thorax flat; head almost smooth, conieal, almost as broad as the thorax, not arched nor ridged, with a slight rim, hardly sinuate along the hind border; its length less than its breadth; face flat on the disc, with very oblique and indistinet strio on each side : shicld minutely striated aeross; seutellum with a 
slightly arched transrerse suture near the tip : tegmina whitish, semitransparent; veins bordered with a darker colour; wings colourless (Waller). Body long, $7 \frac{1}{4}$ : teg. $10 \frac{1}{2}$ millims:

Reported from $\mathrm{N}$. India.

O 32. Ledra pUnctifera, Walker.

Ledra punctifera. Walker, List Hom. B. M. Suppt. p. 2 Ł9 (1858).

Greenish-testaceous (pale green? when alive) ; very minutely punctured, whitish testaceous beneath : hend flat, short, conical, very slightly impressed on each side above, and with a very slight keel beneath : thorax with a very slight impression on each side : tegmina with ramose veins and with a black point in each dise towards the hind border : wings

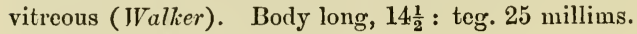

Reported from Darjeeling.

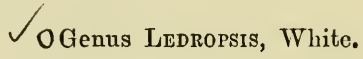

A. M. N. H. xiv, p. 425 (1844).

Head with its prolongation longer than wide, parallel in front of tho eyes, as wide as the thorax, then gradually curved to tho tip, which is somewhat obtnse ; ocelli on the same line with the front of the eyes and rather more distant from each other than from the eyes: eyes large but not very prominent ; prolongation hollowed out beneath, with a spearshaped elevated ridge running down the middle, the base of which, on the face between the eyes, is hollowed out: antenne spring from a depression in front of the eyes beneath, 3-jointed, the terminal joint ending in a longish bristle : thorax rounded in front, very deeply notehed behind, the posterior angles truncately rounded: tegmina with many inclosed cells at the end, the veins robnst : body elongate, margined beneath : tibio of posterior feet not dilated, serrated behind (White).

\section{Ledropsis obligens, Walker.}

$\checkmark$ oLedra obligens, Walker, List Hom. B. M. Snppt. p. 251 (1858).

$\checkmark$ Ledropsis obligens, Stål, Ofvers. K. V.•A. Förh. p. 495 (1862).

Reddish, very clongate-subfusiform, testaceous beneath : head convex, elongate-conical, much longer than broad; under side concave, with a very broad border, the middle compartment lanceolate, black towards the tip of the vertex: thorax convex : abdomen compressed, with a dorsal ridge : tegmina tawny, reticulated; veius very numcrous with

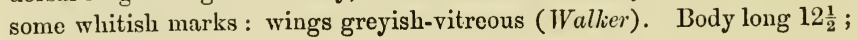
teg. $16 \frac{1}{2}$ millims.

Reported from India? 


\section{$\checkmark{ }^{\text {Genus Tituria, Stål. }}$}

Ofver's. K. V.-A. Förh. p. 158 (1865); Hom. Afrie. iv. p. 102 (1866).

Body large, oblong : head foliaceous, clypeated, triangular, rounded at the apex, produced forwards and a little downwards, vertex flat; frons narrow, flat: face beneath the eyes, abruptly much narrowed, thence gradually narrowed, margins very slightly amplificd : eyes small : ocelli placed behind the middle of the vertex between the eyes, more distant from the eyes than from each other: thornx and vertex in the same plane, somewhat sloped, the former sexangular, angulately amplified on both sides, lateral margins acute, anterior margin straight, posterior margin slightly sinuated : scutellum triangular: tegmina coriaceous, densely punctured, tectiform, reaching the apex of the abdomen, clavus very broad in the middle, corium triangular, obliquely or roundly trineated behind the elavus; veins irregularly anastomosed towards tho apex, less elevated : feet somewhat short : auterior coxw free ; last tibio remotely dentated above. Allied tó Petalocephala, (Stål).

\section{O34. Tituria planata, Fabricius.}

\footnotetext{
DIembracis planata, Fabr., Ent. Syst. iv. p. 11 (1794).

$\checkmark$ Ledra planata, Fabr., Syst. Rhyng. p. 25 (1803).

i) Epiclines planata, Am. \& Serv., Hist. Nat. Ins. Hém. p. 578 (18+3); Walker, List Hom. B. M. iii. p. 831 (1851).

Epiclines hebes, Walker, Ins. Saund. Hom. p. 100 (1858).

$\checkmark$ Petalocephala planata, Stål, Ofvers. K. V.-A. Förh. p. 501 (1862).

D Petalocephala expansa, Stål, Ofvers. l. c. p. 158 (1865).

Tituria planata, Stål, Hem. Fabr. ii. p. 59 (1869).
}

Clypeus flat, triangular, entirely virescent, eyes oblong, fuscous : pronotum smooth, flat, virescent, produced on both sides in a flat point, strong, acute : tegmina virescent, immaculate; body virescent ( $F a b r$.). Olivaceous flavescent turning into virescent; above with the prostethium densely and distinctly punctured; head above finely and sparingly punctured: costa sordidly flavescent: apex of the spines of the last tibio fuscous; head obtusely triangular, more than twice as broad as long; thorax much dilated on both sides, angles acute, the anterior margin of the dilated part about one third longer than the posterior margin, the latter infuscate ; the last ventral segment in the $q$ deeply sinuated at the apex (Stål). 9 , body 18 : breadth of pronotum 10 millims.

Reported from Malacca, India, Tenasserim.

$$
\leadsto \text { Subfamily Proconina, Stål. }
$$

Ofvers. K. V.- $\Lambda$. Förlı, p. 733 (1870). 


\section{- Genus Tetrigonia, H. Geoffroy (in part).}

Hist. Ins. p. 429 (1764) : Signoret, A. S. E. F. (2 sér.) i. p. 13 (1852).

Signoret (in $l$. supra c.) reviews the history of the group, first established by Geoffroy, in his work describing the insects found in the neighbourhood of Paris, under the name Tettigonia. In 1794, Fabricius separated the same group in his Ent. Syst. (iv. p. 27) under the name Cicada, and in his Syst. Rliyn. (1803) formed from it the genera Jassus, Flata, and Cixius. In 1811, Latreille re-established Tettigonia, and, in 1821, (Mag. Ent. iv.) Germar reduced it by creating the genera Gypona,

- Calidea, and others. In 1825, Lepelleticr de St. Fargeau and AndinctServille (Enc. Méth. x. p. 600) formed two divisions, 'T'ettigonia for those in which the head is rounded beyond the eyes and Proconia for those in which the head is conical. In 1829, Latreille (Rigne Anim. 2nd ed., ii, 221) separated Ciccus from Proconia, and, in 1832, De Laporte de Castelnean (A. S. E. F. i, p. 222) formed Germaria and Rhaphidorhinus. In 1835, Burmeister (Handb. ii, (i) p. 117) restored the Tettigonia of Latreille and Germar with four subdivisions, and, again in 1840, Blanchard (Hist. Nat. Ins. iii) admits divisions only. In 1843, Amyot and Serville (Hist. Nat. Ins. Hém. p. 569) admit Tettigonia, Germaria, ticens, Rhaphidortinus, and Proconia, and add Anlacizes, Diestostemma, and - Acopsis. In 1850, Spinola (Tav. Sin. Modena) created Diedrocephala and Wolfella, and, in the same year, Signoret created Dilobopterus (Rev. Zool. (2 sér.) ii, p. 284). In 1851, Fitch formed ${ }^{\circ}$ Helochara for an American species, and, in the same year, Walker created Propetes.

In 1852-54, Signoret (A. S. E. F. (3 sér.) i-iii.) keeps one genus and five groups, and notices some 396 species then recorded from all parts of the world. Stål, in 1869 (Hem. Fabr. ii, p. 59, note), includes the group in his subfamily Jassila and division Proconiida, preserving ${ }^{2}$ Germaria, Ciccus, 'Diestostemma, Thaphidorhinus, Proconia, ant Tettigonia and adding a number of his own genera. In 1870, Stål (Ofvers. K. V.A. Förh. p. 733) raises the group to the dignity of a subfamily under the name Proconiina. In 1884, Taschenberg ('Zeitsch. Nat. Wiss. Halle, p. 431) sinks the genera and reviews the whole as one genus with subdivisions running so closely the one into the other as not to afford good generic characters. After examining the figures given by Signoret, this appears to me to be the most reasonable solution of the difficulties cortnected with the arrangement of the insects belonging to this group, which now number nearly five hundred.

\section{c35. Tettigonia semicircularis, Signoret.}

Tettignnia semicircularis, Signoret, A. S. E. F. (3 sér.) i, p. 348, t. 10, f. 5 (1853) Walker, List B. M. Suppt. p. 219 (1858). 
Head rounded anteriorly, yellow, with two frontal bands united on the clypeus, white : elypens and rostrum black : two half moons united on the vertex, a median band and on each side two spots, black : pronotum transverse with two bands, anterior one narrow and sinuated, posterior broad, uniting with the first, and on each side between them a transverse patch, black : seutellum with a semicireular band proeeding from the base, blaek: tegmina fuscous, with a farinose, powdery substance; lateral margins transparent : abdomen black with the sides and border of the segments, yellow; exterior margin pale, bordered with black, anns white : feet yellow. Long 5-6 millims.

Reported from Pondicherry.

\section{- 36. Tetrigonia pavo, Signoret.}

Tettigonia paro, Signoret, $\Lambda$. S. E. F. (3 sér.) i, p. 675, t. 22 , f. 4 (1853) : Walker, List B. M. Suppt. p. 218 (1858).

Bluishl-black: head rounded, above bluish-black, beneath yellow with the frons and vertex between the eyes depressed : prothorax anteriorly somewhat narrow, yellow, with five spots or patches, black, of which three are on the anterior margin and two, corresponding to two on the base of the scutellum, are on the posterior margin : tegmina red, brown at the tips and exhibiting two bluish circles formed of an easily removeable farinose powder, one of these circles is on the cubital dise near the sentellary angle and the other is at the tip, half in the red part of the tegmen and half in the brown tip : wings brownish : abdomen bluish-black with the margins of the segments beneath, yellow: anal appendage as in T. ferruginea : feet yellow. Long 15 millims.

Reported from Bengal.

\section{c 37. Tetrigonia ferruginea, Fabricius.}

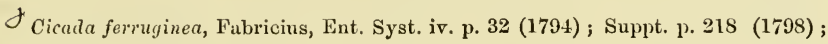
Syst. Rliyng. p. 62 (1803).

CProconia ferruginea, Walker, List B. M. iii, p. 783 (1851).

Tettigonia apicalis, Walker, List 1. c. p. 736, China.

of Tettigonia confinis, Walker, 1. c. p. 736, China.

c. Tettigonia addita, Walker, 1. c. p. 737, Java.

व Tettigonia gemina, Walker, 1. c. p. 737, Java.

(F) Tettigonia olscura, Walker, 1. c. p. 738, E. India.

- Tettigonia duplex, Walker, l. c. p. 738, - ?

- Tettigonia reducta, Walker, 1. c. p. 739, Hong Kong.

OTettigonia longa, Walker, 1. c. p. 740, Philippines.

CTettigonia immaculata, Walker, 1. c. p. 740, Quito ?

-Tettigonia confinis, Walker, 1. c. p. 745, - ?

$\checkmark$ Tettigonia ferruginea, Germar, Mag. Ent. iv. p. 69 (1821) : Signoret, Rev. Zool. p. 176 (1853) ; A. S. E. F. (3 sér.) i, p. 676, t. 22, f. 5 (1853) : Walker, List B. M. Suppt. p. 218 (1858). 
Fabricius describes this speeies thus :- "ITead, thorax mul sentellum spotted with black: tegnima red: wings white. Of modian size: head glancous, with band at the base of the rostrum, and dot on the frons and vertex, dull black: thorax sub-cincreous with an anterior spot and two posterior spots eornmon to the scutellnm, black : scutcllum coneolorous, with the two common spots at the base and one towards the apex, dull black : tegrnina ferrnginous, a little lighter at the tips : body and wings black." Signoret notes that the form of the anal appendage in the $\&$ clistingnishes this species. This is very large, deeply emarginate, covering a great part of the vulvar plates, more or less ronnd on the sides and in shape like two approximated lobes. Walker describes his different species as varying from tawny to red-lead colour, testaecons, luteons or orange : the tips of the tegmina are black, lnrid or brown : posterior margins of abdominal segments and tip of abdomen, red, tawny, lntcons or ferruginous, so that the form of the anal aprendage in the $q$ is the most stealy character for distingnishing a species so variable in colour. Body long, 14-20 millims.

The Indian Musenm possesses specimens from Sumatra, Tenasserim, Arakan, Sikkim, and $\Lambda$ ssam.

\section{Tetrigonia unimaculata, Signoret.}

Tettignnia unimaculatu, Signoret, A. S. E. F. (3 sér. ii. p. 26 (185t) : Stål, Ofrers. K. V.A. Förh. p. 734 (1870).

$\sigma$ Tettigonia kinbergi, Stål, Freg. Eng. Resa, Ins. p. 288 (1859).

Whitish with yellow veins: head triangularly ronnded in front with a black spot between the ocelli and on both sides, above the antennal margin, near the eyes : ocelli blackish and placed in a deep groove: basal band on thorax produced subtriangularly in the middle and two basal spots on the scutellum, black: pronotnm very convex in front, straight behind above the scutellum, anteriorly transversly furrowed: togmina fuscous or yellow-white with the streaks a little brown, costal lalf, whitish hyaline: abdomen and feet yellowish white; vertex impressed on both sides. Allied to $T$. albida, Walker, from which it differs in its smaller size, narrower head, anteriorly more or less obtusely roundlysubangulated, in wanting the median black apical spot, in the thorax being more narrowed forwards, posteriorly a little broader than the head, and especially by the cavities on each side in frout of the eyes in which are inserted the ocelli (Sign., Stål) of Body long, 5 : broad, $1 \frac{1}{2}$ millims.

Reported from Philippines, Malacca, India.

\section{d39. Tettigonia Bella, Walker.}

Tettigonia bella, Walker, List Hom. B. M. iii, p. 778 (1851) : Signoret, $\Lambda$. S. E . F. (3 sér.) ii. p. 10, t. 1, f. 8 (1854).

26 
J3lack, striated und spotted yellow; hend as broad us the thorux, umgulinly comuled in frout, somowhat conenvo postoriorly; vertex with a stripw, a land on llae justerior murgin and a corvod stripo on cach sido, frous unul liace with spols on each sido and somo larger murks in the midlle, fellow ; three pirir of large contiguous lnteons spots on the hend lacoualh, ans: of these an the clypons: thorax black, with a curved

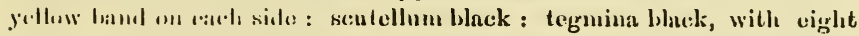
yellow pratclus or spuls; two oblique, busal; two sutural forming a fatc:h ، conmon to the two tegmina and four marginal; of tho latter those wir cach siche wearer the hase, four times longer than the others, tips lurid: ublumen blitek or pmple, tawny at the tip benenth; legs testuceous, mitcrior femoma matkel with bluck : wings brown, irridescent, palo gray fowials the latso. In sinno enses the marks on tho tegminu are oblong müular, mure like longitudinul bunds thum spots (Signe., Walk.). Long $5 !-1 ;$; tog. $1: 2$ ! millims.

licpurted from N. India, Silhut.

\section{$\sigma$ H. 'I'Litigonia assamensis, Distant.}

Tuthigıniu "asamensis, Distaut, Eut. MI. M. xvi, p. 203 (1880).

Hcad pale jellow, with a black fascia occupying tho space between the ocelli ; proucinm creamy white, the lateral margins carmino nud six hlack sputs situateal transversely, two smallest near antorior margin and the four lauger across the disc. Seutellum pale yellow with three black spots, two basal and one subapical : tegmina palo creamy white with a broad longitudinal subcostal carmine band, commencing near the base amil extending to abont the middlo; a black narrow oblique band nearly crossing the tegmina at the base and at commoneemont of the cormino band and five dink fuscous sputs situnted, ono in centro of carmino hand, threo wile apart, lomgitulinully on tho dise, and ono at tho marginal apex of the coriaceous purtion : wings dark fuscous with tho apicul horders broally creany white : abdomen above pitchy, undersillo of body pitchy ; legs lnteons and tarsi pitchy ; face orango ycllow with a lurgo crescent-slajecl black fascia about its centro and a small black spot at the base: the head is rounded in front, much bronder than long, and transversely chamelled on the disc (Distant). Body long, 13 millims.

Rejorted from Assam.

\section{4.1. 'I'etrigonia extresia, Walkes.}

T'ttigøuia entrema, Walker, List Hom. B. M. iii, p. 761 (1851): Signoret, A. S. k. F. (3 sér.) i, 1. 663 , t. 21, f. 4 (1853): Stal, Ofvers. K. V.-A. Förh. p. 495 (181i2).

V O L'uncunthus extremus, )istant, Soiont. Res. 2nd Yarkand Mission, p. 15 (1879). 
Pnle yellow: head lutcous; vertex semicireular in front, liarily concave on the posterior margin, with n slight ritlge on the lise which is mostly ocenpied by a black mushroom-shaped patch of which the stalk rests on the posterior margin between the ocelli ; face smooth, shining, with n slight rielge and on ench gido with imlistinct ohlinge strie : llw-

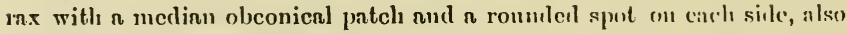
scutellum and abdomen, brownish black : tegmina yellow with an c.lmmgated subtringular blackish-brown stripe tovads the interior margin and a similar stripe along the costr nlmost to the apex, graulually much amplificel towards the apex and itself striped paler: wings clark brown (Iralli., Sign.) Body long $6 \frac{1}{3}$; teg. long $13 \frac{1}{2}$ millims.

lieported from N. India, Murree.

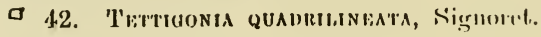

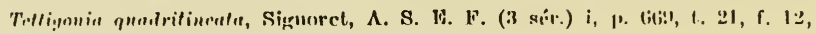
(1853) : Wulker, List Hom. 13. M. Suppt. p. 218 (185s).

llent, thomx, nud scutellum yellow, with two molinen stripse from

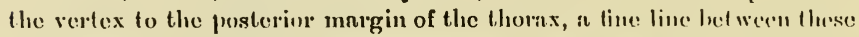
strifies on the vertex, a stripe on the lnteral bonders of the llomas, and threc spots on the scutellum, dark brown : tegmini rest with interripted narrow longitudinal black lines, irregularly dispused in rows, tips piale. Long 12 millims.

leporterl from Is. India.

O 43. Tetrigonia runromacuista, Signomet.

o Teqtligonia cardinalis, Wnlker (nec Fabricins), List Hom. 13. M. iii, 1. 7.1. (1851).

Telligania rubromaculata, Signorot, A. 8. E. F. (3 sér.) i, 1'. 6is\&, t. 21, f. 11 (185:3) Walker, List. I. c. Suppt. j. 218 (1858).

Above decp black: hend with an irregular angular black mark on the vertex, including a subquadrate black mark which procecels from tho hind border: face flat with two black stripes which unite on the clypeus, sides tawny; rostrum piceous : thoonx with a hansverse baml and lateral bands, red: scutellum red with two triangu!ar spots, their bases resting on the anterior margin and $\Omega$ sagillate mak near the alpices of those spots, black : tegmina black with a number of minterrnpted longitudinal red streaks, the ends of most of which on cach fegmen meet the culs of the corresponding strenks on the other tegmen : wings with a metallic tinge : tip of abdomen red; legs red, feet tawny (Signn.). Long with teg. 12-14 millims.

Reported from Nepál: the Indian Muscum possesses specimens from Sikkim and Sibsígnr (Assann). 


\section{Q 44. Tettigonia opponens, Walker.}

Tettignnia opponens, Walker, List IIom. B. M. iii, p. 757 (1851): Signoret, A. S. E. F. (3 sér.) i, 1. 667, t. 21, f. 10 (1853).

Black: head and thorax slightly convox, head bright orange, eoncave along the posterior margin, more convex in front, with two clavato stripes and a spot between the tips of the stripes, black; beneath pale yellow, twice broader than long; face oval with a flat pale orange dise, a black stripe along two-thirels ef each side is united to a black stripe on the elypens, wlich is ridged and slightly compressed; rostrum pale yellow: thorax with a broad orange band which is sometimes half interrupted on the hind border and is waved along the fore border near each sicle of which it inchudes a little black cross streak, also a large subquadrate orange spot whose hind border is notched on each side near the tip of the scutellum which is tawny; legs pale yellow: tegmina dark grey with three orange stripes, eostal and median united at the base, interior. lindly extending beyond the middle, veins brown (Walk., Sign.). Long 1:2 millins.

Reported from N. India.

证

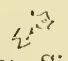

o Sulfimily Acocepialina, Signoret. 1. $\left\{\begin{array}{l}1 \cdots=0 \\ 0\end{array}\right.$

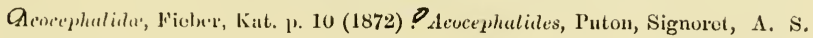
E. 1 . (5 sír.) ix, p. 17 (1s7!)).

\subsection{Acucephalus stramineus, Walker.}

Acncephalus stramineus, Walker, List IIom. B. M. ii, p. $8+7$ (1851) ; Stål, Ofver's.

K. V.-A. Hörh. p. 194 (1862) : Signoret, A. S. E. F. (5 sér.) ix, p. 88 (1879).

obythoscopus strumineus, Distunt, Seient. Res. 2nd Yarkand Miss. p. 18 (1879).

Oli!thoscopus indicutus, Walker, List 1. c. Suppt. p. 266 (1858).

l'ale testaceons; heal slightly rugose, a little narrower than the thorax, rounded and almost semicircular in front, less simuate belind; abont four times bioader than long; vertex longer in the middle than on the sides; two black dots on the anterior border which forms a slight rim; face flat, lroad, punctured : thorax transversely striated : sentellum very slightly punetured: tegmina almost colonrless, punetmred nearly to the tips, pale testaceous towards the base: wings coluurless (Wralier). Body long, $9 \frac{1}{2}$; teg. 21 millims.

Reported from Celebes, Java, N. China, Sind valley.

\section{Genus Hecalos, Stål.}

A. S. E. F. (1 sér.) iv, p. 65 (1864) : Hem. Afric. iv, p. 113 (1866) : Signoret, A. S. F. F. (5 sér.) ix, p. 266 (1879) : includes Glossocrutus, Fieber (Rev. Mag. Zool. (3 sér.) ii, p. 403, 1575). 
Body oblong or elongate, depressed : head somewhat large or some. what so produced, apical margin acute, more or less broadly foliaceous : face dilated, somewhat deeply sinuated below the eyes; frons a littlo convex : eyes small or moderate : ocelli placed on the apical margin of the head or at or near the eyes : thorax transverse, very obtusely rounded at the apex : scutellum triangular, a little broader than long: tegmina almost as long as the abdomen, margined at the apex, valvate behind the clavus, with five apical areas: feet moderate, posterior tibia very spinose. Allied to OSiva, Stål, but differs in the head larger, more produced, margin foliaceous (Stål).

\section{O46. Hecalus sulcatus, Ficber.}

Glossocratus sulcatus, Fieber, Verh. K. K. Zool.-bot. Gesell. Wien. xvi, p. 513, t. 7, f. 13 (1866).

Hecalus sulcatus, Signoret, A. S. E. F. (5 sér.) ix, 1'. 272, t. 8, f. 28 (1879).

Sordid yellow : vertex parallel, parabolic in front, angles very obtusely rounded : prothorax with four clongated eavities in front, finely striated transsersely behind : tegmina transparent, as long as the abdomen : veins strong, yellowish, not margined ; a blackish dut at the point of the clavus : abelomen above with two bands of small brown patelies, two at the base of each segment : feet entirely sordicl ycllow, unicolorous : ventral segments parallel, median lobe obtusely salient, sides sinuated (Fieber). \&, body long, 11 millims.

Reported from E. India. Signoret considers this species to be probably one with II. parva, Walker (List iii, p. 828), though he gives the latter also with ay? as a synonym possibly of $I T$. paykulli, Stål, who, howevor, makes it a Selenocephalus in Ofvers. K. V.-A. Förh. p. 494 (1862).

\section{b47. Hecalus paykului, Stål.}

$\checkmark$ Petalocephala paykulli, Stảl, Ofvers. K. V.-A. Förh. p. 252 (1854).

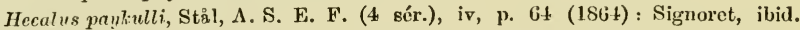
(5 sér.) ix, p. 270 (1879), t. 7, f. 26.

Sordid whitish-yellow, smooth, shining, clouded with brown on the vertex, the length of the median line, and transversely on the prothorax, the tegmina and the veins of the same colour but with a brown line on each side. Head defined on the margin only, one and lalf times longer than the prothorax, as long as broad between the eyes, angularly rounded, the sides almost parallel above the eyes, then forming an anglo at the tip; two excavations on the vertex on each side. Frons convex with a foliaceous border anteriorly, grooved on the sides, border concave above the clypeus which is itself broader at the base than at the tips but showing its greatest breadtl in the middle, carinate in its median part. Rostrum very short. Gene with the tip oblique from the 
clypeus to the eye forming a very aente angle, coneave, sinnous towards the clypeus then emarginate, coneave near the eye. The prothorax a little mere than twice broader than long, finely striated transversely in the posterior half and with several less marked impressions anteriorly. 'I'egmina opaque with four discoidal areas of which two are anteapical, five apical areas and three in the marginal space; a black dot occurs at the tip of the claval angle. Wings hyaline with the third sector rennited at the internal branch of the bifurcation of the second sector, then bifureate and forming a long angular cell. Pectus and abdomen yellow : the latter a littlo deeper towards the base of the dorsal segments. of las last segment of the abdomen hardly longer than the preceding, apieal margin straight; a very small genital appendage; genital plates very narrow at the tip almost as long as the hypopygium and pubescent on the sides; the hypopygium a little broader and pubescent, the anal tube is surrounded by it and extends beyond it by very little. The $q$ lits the last segment twice as long as the preeeding, convex at the superior margin, angular in the middle and weakly sinuated on each side; the genital appendages or valvules are more than twice as long as the preceding and the oviduct extends beyond them by about one-third (Signoret). Stål writes:-Shining, sordid whitish-yellow; head (eyes excepted) almost equally long and broad, longer by half than the thorax, anteriorly slightly narrowed, smoothish : tegmina opaque ; eyes fuscons. 8 Body long 5 ; broad, hardly 2 millims: 9 , body long 6 ; broad, 2 millims : Stâl gives $\subsetneq$ long $8 \frac{1}{2}$; breadth thorax 2 millims.

Reported from China, Senegal, (Australia?), Silhat.

Genus Thomsoniella, Signoret.

A. S. E. F. (5 sér.) x, p. 52 (1880).

Separated fron Clecalus, Stal, by the presence of six discoidal areolas. Body depressed : head prolonged in front, foliaceous on tho anterior margin of the vertex, with a groove throughont its entire length, vertex depressed, also the frous, the latter with the grooves and lateral sutures extending to the anterior border of the head: genæ simnated, ronnded in the middle : the lores occupying the entire space between the margin of the gene and the frontal suture: sides of elypeus almost parallel, romded at the tip, one and half times longer than broad : prothorax transverse, almost broader than the head with the eyes : tegmina transparent hyaline with a narrow marginal limbus : rest as in Ilecalus (Signoret).

\section{48. Thomsoniella kirschidamit, Stål.}

Villecalus kirschbaumii, Stảl, Ofvers. K. V.-A. Förh. p. 737 (1870).

(Thomsoniella kirschbanmii, Signoret, A. S. E. F. (5 sér.) x, p. 52, t. 1, f. 44 (18s0). 
Pale yellow, shining, with a dot at the tip of the clavus and on tho middle of the first apical area, black : anterior margin of vertex blackish. Head a little shorter than broad between the eyes, the anterior margin weakly angularly rounded and reflexed, vertex concave, ocelli in the groove very close to the eyes. Frons convex, almost as long as broad, the sides much rounded : genæ broad with the angle very obtusely rounded. Prothorax convex anteriorly, concave behind, the lateral margins very slightly convex, almost parallel ; finely, transversely striated. Clypeus with the sides parallel, rounded at the tip. Tegmina rounded at the tips with four broad apical and six discoidal cells, the sixth comprising a small hexagonal cellule with equal sides before the third apieal cell ; there is also a supplementary cellule; limbus very narrow, a transverse vein betwen the two veins of the clavus. Abdomen long, the last segment ( 9 ) twice as long as the penultimate with the margin sinuous, emarginate in the middle and furuished with a roumled median lobe; valvules one half longer and the oviduet extending beyoud them by a third. \&, boly long, 6 ; broad, 2 millims.

Reported from Philippines, Ceylon, India.

Resembles $\mathbf{1}$. wallengrenii, Stall, but differs in the more rounded hear, in the number of discoidal cellules, and in the groove on the border of the head (Sign.).

\section{- Genus Selenocephalus, Germar.}

Silbermann's Rev. Ent. i, p. 180 (1833) : Bnrmeister, Handb. ii, (i), p. 111 (1835) : Amyot and Serrille, Hist. Nat. Ins. Hém. p. 583 (18.13) : Stảl, Hem. $\Lambda$ fric. iv, p. 108 (1866) : Fiober, Rev. Mag. Zool. (3 sér.) iii, p. 399 (1575).

Body oblong : head short, broadly rounded at the apex, apical margin with a furrow : vertex flat, horizontal : face dilated, clepressed at the base, lateral margins slightly sinuated beneath the eyes : ocelli placed in the furrow of the apical margin of the head at or near the eyes : thorax transverse, rounded anteriorly : scutellum a little broader than long, triangular: tegmina extending beyond the apex of the abdomen, membranous, margined at the apex, valvate behind the clavus, with $4-5$ apical areas: feet moderate, posterior tibir, a little compressed, very spinose (Stål).

\section{O49. Selenocephalus egregius, Stål.}

Selenocephalus egregius, Stål, A. S. E. F. (4 sér.) iv, p. 66 (1864) : Signoret, ibid. (5 sér.) x, p. 62, t. 2, f. 52 (1880).

Light olive green, smooth; rermillion spots on the head, prothorax and scutellum, glossy. Head very little broaler than the prothorax, rounded in front; vertex not longer in the niddle than towards the 
eyes, with a biurenated band of vermillion, margin with a slight groove, ocelli a little distant from the eyes; frons with the sutures concave, then convex at the tip, weakly impressed in front. Clypeus one and half times longer than broad, spatuliform; lores much rounded; gene broad, tip convex, a little sinuate in front of the subocular piece. Prothorax two and half time broader than long, thrice longer than the vertex and with a vermillion band in front which starting from the middle of the anterior margin proceeds obliquely towards the middle of the lateral borders where it ends in a round spot. Scutellum broader than long with four ronnd dots at the base, two lateral towards the transverse stria and the tip, vermillion. Tegmina hyaline golden-yellow with the side strong and vermillion up to beyond the middle, veins blackish, the transverse blacker and with two lateral spots along the borler, three at the suture and the extremity, black. Wings slightly infuscate with a lighter space in the supplementary cellule: body and fect yellow olive with decper shades at the base of the abdominal segments : last ventral segment in of scarcely longer than the preceding, emarginate in the middle with a median lobe, the sides very oblique, trilobate : valvules thick, round, pubescent at the extremity; hairs yellow at the base, black at the tip: oviduct blackish just extending beyond the valvules (Sign.). $\&$, body long, 8 millims.

Reported from Burma.

\section{○ 50. Selenocephaldos cultratus, Walker.}

OLedra culobata, Walker, List Hom. B. M. iii, p. 827 (1851).

O Ledra cultrata, Walker, l. c. iv, p. 1159 (1851).

Selenocephalus cultratus, Stål, Ofvers. K. V.-A. Förh. p. 494 (1862).

Testaccous, almost fusiform; head conical, as broad as the thorax, shagreened, very slightly arched, very slightly concave along the hind border, with a very indistinct middle ridge, on each side of which there is a very slight furrow ; its length a little less than its breadth ; sides slightly angular; fore-part of the underside with slight diverging ridges which are at right angles to the slight oblique ridges on each side of the face; a piceous spot in front of each eye : ocelli near the hind border: thorax very slightly convex, hardly striated transversely, indistinctly impressed on each side; scutellum with a slight arched transverse suture near the tip : abdomen as broad as the thorax with seven slight black stripes : legs marked with black : tegmina pale testaceous, not punctur-

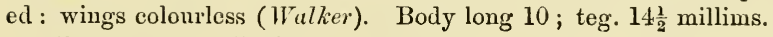

Reported from India.

$$
\checkmark \text { i)genus Petalocephala, Stål. }
$$$$
\text { fis inds: }
$$

Stål, Ofvers. K. V.-A. Förh. p. 266 (1856); Hem, Afric. iv, p. 103 (1866). 
Body very oblong or a little elongate, depressed : head clypeated, foliaceous, produced anteriorly; vertex somewhat flattish; face beneath the eyes abruptly very much narrowed, thence gradually, margins very slightly defined; frons small, narrow, flattish : eyes small : ocelli situate towards the baso of the vertex, more distant from the eyes than from each other : thorax transverse, sexangular, not or only very sliglitly narrowed forwards, lateral margins acnte, anterior-lateral much longer than posterior-lateral, anterior margin slightly rounded: scutellum triangular, subequilateral : tegmina subcoriaceous, pellucid, densely punctured, tectiform anteriorly conjointly convex, clavus very broad before the middle, corium obliquely rounded at the apex, veins irregularly anastomosed towards the apex, less distinct: feet somewhat short; first coxæ free; last tibio above remotely dentated. OType Petalocephala bohemani (Stål).

\section{VD51. Pétalocephiala chloroceritala, Walker.}

$\checkmark \bigcirc$ Ledra chlorocephalus, Walker, List Hom. B. M. iii, p. 825 (1851).

/Petalocephala chlorocephala, Stál, Ofvers. K. V.-A. Förh. p. 494 (1862).

Testaceous, paler beneath, almost fusiform; head and thorax thickly punctured; head flat, eonical, as broad as the thorax, very slightly arched, very slightly concave along the hind border, green in front with a median ridge; its length a little more than half its breadth; three ridges beneath, the middle one tapering to the fore border, the side pair curved ontward : thorax almost flat, shield tinged with green on each side of the hind border: legs pale testaceous : tegmina alnost colourless, testaceous towards the base, brown at the tips, with a small black spot in each disc: wings colourless (Walker). $\delta$, body long, 10 ; teg. 20 millims.

Reported from N. India.

\section{$O$ Genus Siva, Spinoln.}

Gen. Ins. Artr., p. 167 (1852) : Stål, Hem. Afric. iv, p. 112 (1866) : Signoret, A. S. E. F. (5 sér.) x, p. 197 (1880).

Body very oblong, somewhat depressed, above slightly convex : head narrower than the thorax, short, rounded anteriorly or obtusely rounded subangularly, anterior margin somewhat acute but not foliaceous : vertex horizontal, flat, about twice broader than the eyes ; face dilated, frons and clypeus somewhat flat; frons longer than broad; clypeus spatuliform; genæ broad with the angle more or less angular and more or less emarginate : ocelli placed at the eyes on the anterior margin of the head: thorax transverse, narrowed forwards, twice broader than long, slightly rounded at the apex, almost straight above 
the scutellum, lateral margins acute: scutellum triangular, a little broader than long: tegmina barely extending beyond the tip of tho abdomen, tip narrow, irregularly veined : feet moderate, last femora compressed, last tibix very spinose. Allied toQselenocephalus.

\section{O52. Siva strigicollis, Spinola.}

Siva strigicollis, Spinola, Tav. Sinot. p. 127 (1852) : Signoret, A. S. E. F. (5 sér.) x, p. 198, t. 6, f. 64 (1880).

O Selenocephalus costalis, Stål, Freg. Eug. Resa, Ins. p. 290 (1859): A. S. E. F. (4 sér.) iv, p. 66 (1861) o.

1) Siva costalis, Stål, Ofvers. K. V.-A. Förh. p. 736 (1870) ㅇ.

Very pale ycllow with two black spots on the tip of the vertex and one at the tip of each clavus : head and pronotum striated transversely. Head narrower than the pronotum, round in front, thickened and reflexed, with two small black median spots, a median line and slight transverse striw; breadth between the eyes a little smaller than the eyes together : face transversely striated, stronger and more oblique on the sides : frons longer than broad, flat at the base, more convex at the tip, the grooves and base of a brighter citron yellow : genæ with parallel circular streaks on the upper border which is circular, slightly sinuate beneath the cyes, the portion below the eyes and antenno, glossy: clypens twice longer than broad, broadly spatuliform at the tip, transversely striated and a little carinate at the base : lores longer than broad. Pronotum twice broader than long, grooved strongly and almost parallel, anterior border slightly convex, sides oblique and posterior border almost straight, angles oblique : scutellum broader than long with three spaces bounded by the angles, those at the base almost glossy, that at the tip, strongly transversely striated. Tegmina rugose, punctured, longer than the abdomen, veins strong: wings large, milky. Pectus yellow with paler spaces; feet yellow, femora flat, posterior tibiæ very spiny : abdomen uniform yellow.

$\delta$ last ventral segment much larger than the penultimate but less broad, pubescent, almost square with the apical margin almost straight a little sinuate in the middle, angles round; covering almost entirely the plates of the genitalia and of half the hypopygium; the former very narrow, slightly pubescent; the latter forming two valves irregularly rounded at the tip and armed on the disc and sides with a few spiny hairs.

i last ventral segment a little longer on the sides than the penultimate not longer in the middle, lateral angles, acute, round at the tip, the middle concave, without sinnosities: the valvules four times longer, hardly pubescent, cxtending a little beyond the oviduct which is short 
and enclosed by the dorsal tip of the valvules, the anal tip visible from below, invisible from above (Śgn.). Body long, 10-11 millims.

Reported from Philippines, Coromandel, India.

\section{OGenus Drabescus, Stål.}

Subgenus, Ofvers. Kong. Vet. Aka. Förh. p. 738 (1870) : Dabrescus, Signoret, A. S. E. F. (5 sér.) x, p. 207 (1880).

Ocelli remote from the eyes, almost more distant than the antenno : anterior tibiæ above broadly subsulcate, superior margin of the first tibiw distinctly dilated: formed from Oselenocephalus.

\section{O 53. Drabescus nervosopunctatus, Signoret.}

Dabrescus nervosopunctatus, Signoret, A. S. E. F. (5 sér.) x, p. 209, t. 7, f. 72 (1880).

Yellow, spotted with brown : vertex very short, at least four times broader than long between the eyes, a little longer towards the eyes than in the middle; in front a blackish patch and in the mildle, a black median line: ocelli as distant from the eyes as from the median line: frons black, very finely rugose, almost as long as broad at the base which is yellowish, but bounded on the margin itself of the head by a blacker line which is continued on the eyes in a lighter shade. Scrobe oblique reaching the vertex at the level of the eyes. Clypeus black, carinate, spatuliform, rugose and with two small excavations at the tip: Genæ yellow with a blackish spot beneath the antennæ which is punctured with yellow dots ; almost as broad as long, with the border free, straight from the clypeus to the external angle of the eye with a weak sinuosity above the anterior coxæ and a stronger beneath the eyes. Antennæ very short, yellow, the base of the second joint and the third joint black. Pronotum nearly thrice broader than long, yellow-brown, with brown spots furnished with light yellow round dots; finely striated transversely in all its length. Scutellum brown, with irregular, long or round dots, yellow. Tegmina golden-yellow hyaline, in appearance rugose, and furnished with brown veins, almost black with white dots regularly placed, the side brown, punctured white; in addition a band at the basal third and almost the upper half, brown, lighter in the middle but forming deep spots on the side in a line with the transverse diseoidal vein on the suture at the level of the tip of the clavus, in a line with the transverse veins of the apical cellules; extremity of the apical cellules and the limbus, blackish. Wings hyaline, infuscate at the tip : pectus and feet yellowish brown; base of the spines of the posterior tibire and the tip of the claws, blackish : abdomen yellow, with the median part of tho 
dorsum broadly, a narrow median band on the venter, the tip of the last segment and the oviduct, black. $\%$ with last segment twice as long as the preceling, weakly sinuate at the tip with a very small extension in the middle (S'ign.). \&, body long, 10 ; broad, $3 \frac{1}{2}$ millims.

Reported from N. India.

\section{54. Drabescus angulatus, Signoret.}

Dabrescus angulatus, Signoret, A. S. E. F. (5 sér.) x. p. 210, t. 7, f. 73 (1880).

In appearance very liko D. nervoso-punctatus, Sign., from which it differs by the vertex being angular in the middle, frons longer, tegmina rugose althongh hyaline, the rugosities very close to each other, yellow, whitish at the tip and streaked with black in the hollows which they form, veins brown alternated with white dots, clavus with two transverse veinlets, one between the two veins and the other between the anal vein and the claval suture. Tegmina with a white, rugose, hyaline, basal band; a broad band, streaked black; a white hyaline band; a broad band streaked with black on the anteapical areas; further the length of the apical cellules, of a golden hyaline, yellow, glossy not rugose, the marginal border deeper infuscate with a brown spot at the tip of the fourth external apical area.

Vertex very short angularly rounded in front, a little longer in the middle than towards the eyes, concave in the latter direction, convex in the mildle, the extreme edge forming a light yellow ridge bounded on the vertex by a black line, on the frons by a black band confluent with the frons itself/ which is black, yellowish brown at the tip and along the sides; longitudinally striated and withont lateral grooves. The romainder as in $D$. nervosopunctatus, except that the o has the last ventral segment strongly cmarginate in the middle, sinuated on the sides, the angles angularly rounded, and at this point twice as long as the preceding segment, although in the middle it is hardly as long. Oviduct and genital plates yellow, the latter a little shorter of the two (Sign.). Body long, 9 : broad 3 millims.

Reported from N. India.

\section{ASubfamily JASSiNa, Stål.}

Ofvers. K. V-A. Förh. (pt.) p. 735 (1870).

\section{OGenus JASSUS, Fabricius.}

Syst. Rhyng. p. 85 (1803) : Stål, Hem. Afric. iv. p. 119 (1866) : Spångberg, Ofvers. K. V.-A. Förh, no 8 p. 3 (1878) OCalidia, Germar, Burmeister.

Body oblong, subcylindrical ; head a little narrower than the thorax, obtuse or very obtuse on the anterior margin : vertex horizontal, a little 
narrower than the eyes, gradually somewhat amplified forwards; face dilated, more or less reclined, frons occupying the greatest part of the intraocular breadth of the face, very slightly convex; clypeus produced and amplified at the apex, truncated : ocelli situate on the apical margin of the head near the eyes : thorax transverse, short, shorter tlan the scutellum : scutellum hardly shorter than long, subequilateral, large : tegmina margined at the apex, valvate behind the clavus, with five apical areas : feet somewhat long; posterior tibiæ very spinose (Stål).

○ 55. Jassus deplanatus, Spångberg.

Jassus deplanatus, Spångberg, Ofvers. K. V.-A. Förh. no 8, p. 23 (1879).

○ ? Celidia indica, Walker, List Hom. B. M. iii. p. 855 (1851).

0 ? Tettigonia jactans, Walker, 1. c. Suppt. p. 357 (1858).

Sordid yellowish white; vertex, face and feet weakly subferrnginous yellowish, sides of frons weakly cinnabar : pronotum and sentellnm llack-fuscous, the former with sordidly flavesecut-white granules; pectus and abdomen black, the former more or less spotted with flarescent, segments of the latter, posteriorly, narrowly margined with sordid yellow; tegmina sordidly flavescent white, densely spotted with fuscous; costal spot a little beyond the middle subtriangular, large, sordidly whitish hyaline and a fuscous spot placed behind the preceding, both fuscescent at the apex, reins more obscure, fuscous, sordilly spotted with white: wings fuscescent. The last segment of the abdomen in the $q$ almost twice as long as the penultimate, slightly sinnated on both sides at the apex, median lobe somewhat produced, rounded posteriorly (Spangberg). + , body long, 8 ; broad, $2 \frac{1}{2}$ : body and tegmina long, 9 millims. Reported from E. India.

O Genus Thamotetrix, Zetterstedt.

Ins. Lapp. p. 292 (1810) : Stål, Hem. Afric. p. 101, 122 (1866) : Scott, E. M. M. xii. p. 21 (1875).

Body oval or very oblong: head variable in breadth and shape, obtuse or very obtuse on the anterior margin : vertex horizontal: face dilated, reclined, slightly convex; frons occupying the greatest part of the intraocular breadth of the face: ocelli placed on the anterior margin of the head at or near the eyes : thorax transverse : scutcllum moderate or small, equal in lengtli to the thorax or shorter: tegmina membranous with 4-5 apical areas, most often valvate and margined at the apex : feet moderate, posterior tibiæ, very spinose (Stål).

O 56. Thamnotettix bipunctata, Fabricius.

( Cicada 2-punctata, Fabricins, Syst. Rhyng. p. 78 (1803).

Thamnotettix bipunctata, Stål, Hem. Fabr. ii. p. 82 (1869).

38 
Yellowish green, shining, smooth : frons (except the lateral margins) entire lores or beneath the middle, a spot before the middle and the apical two-fifths of corium and lateral spots on the pectus and abdomen, black, the incisures of the abdomen greenish-yellow: wings infuscate. $\delta$, body long $4 \frac{2}{3}$; broad, $1 \frac{1}{6}$ millims.

Reported from Tranquebar. Head searcely as broad as the thorax and a little shorter very obtusely roundly subangulate: vertex about twice as broad as the eyes, hardly twice as broad as long, slightly impressed within the anterior margin; face very slightly convex : thorax hardly more than two and half times broader than long, obtusely rounded anteriorly : tegmina rounded at the apex, valvate behind the clavus (Stål).

\section{Genus Hruica, Stål.}

Stål, Trans. Ent. Soc. Lond. (3 sér.) i. p. 593 (1863).

Body oblong-obovate : liead acutely produced, face somewhat reclined : ocelli placed on the upper part of the head, near the anterior angles of the eyes: rostrum very short: thorax somewhat elevated backwards, tubereulated, anterior lateral margins long, anterior middlo angularly produced : scutellum elevated, tuberculated : tegmina subcoriaceous, broadly membranously margined at the apex : abdomen broader than the tegmina, posterior segments acutely lobed and reflexed on both sides : feet somewhat short, anterior tibir above somewliat dilated, posterior above spinose. Close tœTettigonia (Stål).

\section{VO 57. Hylica paradoxa, Stål.}

Hylica paradoxa, Stål, Trans. Ent. Soc. Lon. (3 ser.) i. p. 593 (1863).

Body oblong-obovate, blackish or fuscous-testaceons ; face below the middle (a black spot excepted), disc or two broad stripes on the venter sordidly stramineeous! ${ }^{\circ}$ Var. $a$, feet sordidly stramineous, annulated with fuscous. OVar. $b$, feet fuscous-testaceous; femora palely banded. $\$$, body long, 10 : broad, $3 \frac{1}{2}$ millims.

Frons produced at the base in a short, compressed, slightly curved horn and furnished in the middle with two small tubercles: two posterior, distant tubereles on the thorax, higher than the rest, compressed: seutellum much elevated before the middle, furnished near the apex with a conical tubercle ; disc of the elevated part hollowed out and more compressly-elevated on both sides (Stål).

Reported from Burma.

\section{$\checkmark$ OGenus Penthimia, Germar.}

Mrag. Ent. iv. p. 46 (1821). Stål, Hem. Afric. iv. p. 100. 107 (1866) : Fieber. Rev. Mrag. Zool. (3 sér.) ii. p. 392 (1875). 
Body oval or ovate, somewhat depressed : lead obtuse, anteriorly rounded; vertex somewhat sloped, slightly convex before the mirldle; lateral margins of face, somewhat distinct; frons a little convex; clypeus flat or very slightly convex: eyes moderate: ocelli placed on the disc of the vertex, more distant from each other than from the eyes : thorax transverse, a little narrowed forwards, anterior margin round: tegmina margined at the apex, valvate behind the clavus, 4-5 apical areas : feet moderate; femora compressed; last tibix very spinose (Stål).

O58. Penthimia orientalis, Walker.

Penthimia orientalis, Walker, List Hom. B. M. iii. p. 841 (1851).

Deep black, oval: head and chest convex, thinly puncturerl: posterior border of pectns, red : tegmina thickly punetured; tips of tegmina and wings brown. Body long, $7:$ teg. $14 \frac{1}{2}$ millims. $\Lambda$ variety has tho abdomen red on each side towards the tip : anterior tibio and fect mostly red (Walker).

Reported from N. India.

V 59. Penthimia compacta, Walker.

Penthimia compacta, Walker, List Hom. B. M. iii. p. 812 (1851).

Ferruginous, short, broad: head and antcrior margin of thorax, black: head very short, nearly as broad as the thorax, slightly concave posteriorly, rather more convex in front; face convex, distinctly transversely sulcated; thorax convex, minutely punctured black towards the fore border : tegmina piccous, ferruginous along the posterior margin : wings almost colourless (Walker). Body long, 3 : wings long, $6 \frac{1}{4}$ millims.

Reported from N. India.

$\checkmark$ O 60 . Penthimia castanea, Walker.

Penthimia castanea, Walker, J. L. S. Zool. i. p. 98 (1856).

Ferruginous, smooth, shining: head black in front and beneath : pectus black in front and with a black spot on each side behind: legs black; tibir very spinose : tegmina lurid and with black spots towards the tips (Walker). Body long, 5 ; teg. $10 \frac{1}{2}$ millims.

Reported from Malacca, Tenasserim.

Adpitions and Corrections.

- 61. Monecphora trimacula, Walker.

Monecphora trimacula, Walker, List Hom. B. M. iii. p. 682 (1851).

Body long, $7 \frac{1}{4}$ : exp. teg. $18 \frac{3}{4}$ millims : reported from India. 
62. Sphenoriina contigda, Walker.

Sphenorhina contigua, Walker, l. c. p. 695 (1851).

Body long, $8 \frac{1}{2}$; teg. $18 \frac{3}{4}$ millims : reported from N. India.

6) 63 . Sphenomina intermedis, Walker.

Sphenorhina intermedia, Walker, List l. c. p. 695 (1851).

Body long, $7 \frac{1}{4}$ : teg. $16 \frac{3}{4}$ millims : reported from N. India.

o 64. Spinenorhina proxima, Walker.

Sphenorhina proxima, Walker, List l. c. p. 695 (1851).

Body long, $7 \frac{1}{4}:$ teg. $14 \frac{1}{2}$ millims : reported from N. India.

06 . Spilenoriuna braconoides, Walker.

Sphenorhina braconoides, Walker, l. c. Suppt. p. 185 (1858).

Body long, $6 \frac{1}{2}$ : teg. $16 \frac{3}{4}$ millims : reported from Burma.

3 66. Spilenoriina approximans, Walker.

Sphenorhina approximans, Walker, I. c. Suppt. p. 185 (1858).

Body long, $6 \frac{1}{2}-8 \frac{1}{2} ;$ teg. $16 \frac{3}{4}-19$ millims : reported from N. India.

○ 67. Poophilus costalis, Walker.

Ptyelus costalis, Walker, List Hom. B. M. iii. p. 707 (1851) : Stål, Ofvers. K. V.A. Förlı. p. 493 (1862).

C Ptyelus concolor, Walker, List 1. c. p. 715 (1851).

6) Ptyelus dolosus, Walker, List 1. c. Suppt. p. 189 (1858).

Ptyelus rotundatus, Signoret, in Thoms. Arch. Ent. ii. p. 332 (1858).

C Ptyelus natulensis, Stål, Ofvers. K. V.-A. Förh. p. 97 (1858).

O Poophilus natulensis, Stàl, Hem. Afric. iv. p. 74 (1866).

More or less weakly or obscurely ivory-grey, pubescent; tegmina varied with fuscous; frontal part of anterior margin of the heal, pallid, with five black spots : wings colourless, slightly infuseate at the apex: ventral disc black : tegmina nearly thrice longer than broad, apical lialf narrowed: frons and anterior feet, fuscous; apex of femora pallid ( $P$.

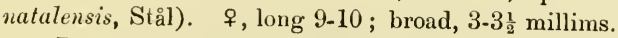

Reported from S. and W. Africa, Ceylon, N. Inclia. Stål notes that his Ceylon example differs from the S. African in the head being a little more obtuse and more ronnded.

68. Clovia conifer, Walker.

- Ptyelus conifer, Walker, List Hom. B. M. iii. p. 711 (1851); J. A. S. B. lir. (2), p. 19 no. 38 (1885).

- Ptyelus simulans, Walker List 1. c. p. 717 (1851). (186\%).

Ptyelus frenułutus, Stål, Ofvers. K. V.-A. Förl. p. 250 (1854): 1. c. p. 493 
Head and thorax ferruginous, flat, very thickly and minutely punctured, covered with tawny down : head short, indistinctly striped with brown, sinuate along the hind border, more rounded in front, its length not more than one-fourth of its breadth ; face piceous, roughly punctured, with ten slight oblique ridges on each side of the disc which is flat; two yellow stripes along the sides unite near the front and form a cone and are produced along the pectus : the clypeus shining, convex, ferruginous, with an oblique furrow on each side ; rostrum ferruginons, tip piceous; pectus with a broad black band between the anterior and intermediate legs: abdomen ferruginous, testaceous at the base: legs testaceous : tegmina ferruginous, conical towards the tips which are almost pointed, nearly colourless for half the breadth beneath the foreborder from the middle to the tips; some forked brown streaks in the disc, a few of them communicating with an irregular curved brown stripe which extends from three-fifths of the length of the fore-border to the tip and is darkest at each end : wings colourless ; veins black, tawny at the base (Walker). Body long, $6 \frac{1}{4}$; teg. $16 \frac{1}{2}$ millims.

Reported from India, Java.

- 69. Clovia punctum, Walker.

- Ptyelus punctum, Walker, List Hom. B. M. iii. p. 718 (1851); Stảl. Ofvers. K. V.-A. Förh. p. 493 (1862) : J. A. S. B. liv. (2), p. 19 (1885).

o Ptyelus bipunctipennis, Stål, 1. c. p. 250 (1854) : Java.

Pale tawny, covered with pale down : heal and thorax almost flat: head very convex in front, with two furrows which diverge from the fore border and communicate with two more oblique impressions near the hind border; face very convex, with a blackish disc, which has about eight oblique ridges on each side; disc of the breast, blackish : tegmina with a dark brown dot on the hind border near the tip ; wings colourless; veins pale stramineous (Walker). Body long, $5:$ teg. $11 \frac{1}{2}$ millims.

Reported from N. Bengal, Java.

- 70. Ptyelos sexvittatus, Walker.

Ptyelus sexvittatus, Walker, List Hom. B. M. iii. p. 715 (1851) ; J. A. S. B. liv. (2), p. 19 (1885).

Yellow, shining : head and chest flat, minutely punctured, adorned with six black stripes : head concave along the hind border, almost conical in front; its length less than laalf its breadth; face very convex with indistinct ridges on each side, black towards the clypens which is also black : disc of the pectus mostly black : abdomen piecous : a slort dorsal stripe, hind borders of the segments, and oviduct, tawny: lcoss 
yellow ; tips of the hind tibire and of the hind feet, piceons : tegmina brown, narrow, with two very large white spots on the fore border, with two indistinct whitish marks near the base, and with two more along the hind border: wings colourless; veins tawny, pale yellow towards the base ( $\mathrm{Valker}$ ). Body long, 5 ; teg. $12 \frac{1}{2}$ millims.

Reported from N. India.

\section{- 71. Ptyelus subfasciatus, Walker.}

Ptyelus subfusciatus, Walker, List Hom. B. M. iii. p. 724 (1851) ; J. A. S. Ben. liv. (2), p. 19 (1885).

Pale tawny, shining, very finely punctured: head above luteous, slightly concave along the hind border, very convex in front; face very convex, piceons towards the clypeus which is also piceous ; ridges on each side very slight: thorax with six brown stripes; a brown spot on each side by the base of the tegmina : disc of the pectus, black : abdomen piceous, pale tawny at the base: tips of the hind tibiæ, black: tegmina brown with a tawny spot on each side at the base and with two white bands, the first not reaching the hind border, the second interrupted in the middle: wings colourless, veins tawny (Waller). Body long, $3 \frac{1}{2}:$ teg. $8 \frac{1}{2}$ millims.

Reported from N. India.

\section{Urophorà hardWickil, Gray.}

Urophora hardwickii, Gray, Griffith's ed. Animal kingdom, Ins. ii. p. 261, t. 90, f. 3 ; t. 138, f. 5 a-d. (1832) : Walker, List Hom. B. M. iii. p. 645 (1851).

The eharacters of the genus and species are given thus by Gray :" the thorax produced over the head; the posterier legs simple and with the ovipositor forming a long tube; fulvous with the tegmina spotted between the veins with brown; the legs and ovipositor obsenre": near Chthulion, Latr. Body long, 18; ovipositor long, 13 millims.

Reported from Nepal: the Indian Museum possesses specimens from Sikkim, Assam.

Journal, liii. (2) No. 3 for 1884, p. 219 No. 26, H. transversa, Walker is the same as Greana dives, West l. c. p. 221, No. 34.

1. c. p. 224 , D. lateralis, Walker, No. 41 is the same as D. vibrans, Walker, No. 43.

l. c. p. 225, D. immacula, Walker, No. 52 is the same as D. mannijera, Linn, No. 39.

1. c. p. 229, omit C. subtincta, Walker, No. 70: Walker's locality is incorrect.

1. c. p. 229. C. ancea, Walker, No. 71 is included in C. striata, Walker, List i. p. 206. 
1. e. p. 230. Cicada subvitta, Walker, No. 73 is a Tibicen.

1. e. p. 230. Cicada xantes, Walker, No. 75 is a Cicadatra.

1. c. p. 231, Fidicina operculata, No. 81 is the same as Fidicina Bubo, Walker, List, p. 82 and is a CRTPtotym pana.

1. c. p. 231. ${ }^{\circ}$ Fidicina corvus, Walker, No. 82 is a Cryptotympana.

1. c. p. 232 . T. apicalis, Germar, No. 14 includes also Cicada semicincta, Walker, List, i. p. 142.

l. e. p. 232. ${ }^{O}$ M. illustrata, Am. \& Serv. No. 85 and $M$. recta, Walker, No. 86 are the same as $M$. conica, Germar.

1. c. 233 . M. quadrimacula, Walker, No. 93 is a Cicadatra.

1. c. p. 233 . M. terpsichore, Walker, No. 94 is a Dundubia.

Jourual liv. (2) No. 1 for 1885 , p. 19 . P. quadridens, Walker, No. 39 ineludes as a variety Clovia guttifer, Walker, 1. c. p. 20, No. 44 and is a Clovia. 
From the Joumal, Asiutic Society of Bengal, Vol. LIV, Part I, 1885.

Notes on Indiun Rlymehota. No. 4.-By E. T. Atrinson, B. A.

[Receired Jnly 7 th ;-Read August 5th, 1885.]

Family Fulgoride, Leach.

Elin. Ency. ix (1817); Westwood, Mod. Class. Ins. ii, p. 427 (1810); Fieber, Verh. Zool.-Bot. Gess. Wien, xvi, p. 497 (1866):-Fulgorelle, Latr. Gen. iii, p. 163 (1807); Spinola, A. S. E. F. (1 sér.) viii, p. 133, 202 (1839) :-Fulgorina, Burm., Handb. Ent. ii (i) p. 102, 144 (1835):-Fulgorida, Stål, Hem. Afric. iv, p. 128 (1866).

Two ocelli, rarely three or none, one on each gena ; third, when present, placed on the apex of the frons : genæ reflexed, very often separated from the frons by a ridge : tegmina at the base with a tegula, which is seldom wanting, hidden : anterior coxø inserted near the sides of the body, very often clongate ; last pair, transverse, contiguous, extended to the lateral margins of the body (Stål).

S Subfamily Fulgorina, Stål.

$\checkmark @$ Fulgorides, Am. \& Serv., IHist. Nat. Ins. Hém. p. 488 (1843). " Fulgorida, Stål, IIem. Afric. iv, p. 129 (1866), Stettin Ent. Zeit. xxxi, p. 255, 282 (1870); Fulgorina, Stål, Ofvers. K. V.-A., Förh. p. $7 \pm 0$ (1870).

Anal area of wings reticulated the ridge separating the frons from the genæ is continued in the sides of the clypeus (Stal).

\section{$r$ \& Genus Fulgora, Linnæus, Stål.}

Fulgnra, Stål, IIem. Afric. iv, p. 133 (1866) ; Hotinus, Am. \& Serv., Uist. Nat. Ins. Hém. p. 490 (1843) : Walker, List Hom. B. M. ii, p. 264 (1851). 
Vertex much broader than the eyes: head furnished with a long process, rounded or subtetragonal: genæ truncated before the eyes: frons slightly sinuated at the apex, furnished with $2-3$ longitudinal ridges : feet slender: seutellum slightly carinated; cephalic process more or less curved (Stål).

\section{A. Section with (when dead) orange wings.}

\section{$\checkmark{ }^{\circ} 1$. Fulgora candelaria, Linnæus.}

$\checkmark$ Cicada candelaria, Linn., Acta Holm. p. 63, t. 1, f. 5, 6 (1746) : Rosel ron Rosenhof, Ins. Belust. 2, Gryll. p. 189, t. 30 (1749) ; Sulzer, Ins. t. 10, f. 62 (1761).

vaternaria candelaria, Linn. Mus. Lad. Ulr. p. 153 (1761).

1 Fulgora candelaria, Linn. Syst. Nat. i (2) p. 70 (1766); Do Gíer, Cigale chinoise portc-lanterne, Ins. iii, p. 197 (1773) ; Fabricius, Syst. Ent., p. (i73 (1775) ; Spee. Ins. ii, p. 313 (1781); Gmelin, ed. Syst. Nat. i (4) p. 2089 (1782) ; Fulr. M:unt. lus. ii, p. 260 (1787) ; Ent. Syst. iv, p. 2 (1798); Syst. Rlyyng, p. 2 (1803); Olivier, Ene. Méth. vi, pp. 568 , 593, t. 109, f. 3 (1790) : Stoll, Cigalles, (Cigule Chinoise), p. 4t, t. 10, f. 4.6 A. (1758) : Burmeister, IIandb. Ent. ii (i) p. 168 (1835) : Westwood in Donovan's Inscets China, t. 14, (1842); Trans. Limn. Sue. XVIII, p. 138 (1811): Blanchard, Ilist. Nat. Ins. Hém. t. 12, f. 1 (1840-41); Butler, 1'. Z. S. p. 97 (1874).

- Flata candelaria, Germar, Mag. iii, p. 189 (1818).

- Pyrops canclelaria, Spinola, A. S. E. F. viii, p. 238 (1839).

$\checkmark$ IIotinus candelarius, Am. \& Serv., Hist. Nat. Ins. If́m. p. 490 (1813) ; Walker, List. Hom. B. M. ii, p. 265 (1851).

Head produced in a horn, as long as the body, subulate, ascending, obtnse, somewhat compressed, subangulate, red, sprinkled with milkwhite spots: eyes subglobose, a globose pellucid dot beneath the eyes : antennæ beneath the eye, very short, two-jointed, lower joint cylindrical, upper subglobose, fuscous, ending in a very small seta : thorax testaceous, like the three-cornered scutellum; abdomen, above fulvous, bencath black, with luteous margins : tegmina fuscous, reticulated green and adorned with various luteous spots margined with whitish of which the first band is transverse and the second cruciform, the rest round : wings lutcous, broadly black towards the apex : feet flavescent, first and second tibia black, third denticulate (Linn. M. L. U.). Long 40-45; cephalic process 15-20 millims.

Reported from China, Cambodia, India. The Indian Museum possesses specimens from Sikkim, Assam. The next three appear to be little more than local varieties of $F$. candelaria.

2. Fulgora brevirostris, Butler.

1 Fulgora brevirostris, Butler, Proc. Zool. Soc. p. 97, 1 t. xr, f. 1, (197 t).

Closely allied to $F$. candelaria; tegmina black, with the reins and spots bright ochraceous, disposed as in $\mathrm{F}$. candelaria ; wings orangeoclureous, the apical third black; cephalic process short, eurved, ascend- 
ing, testaceons with paler spots: prothorax much compressed in front, with a central longitulinal rilgo and two strongly impressed black punctures, testiceous, with a black lateral pateh; tho rest of tho body, liteous above, mesutholitx maculated with black; ablomen below blick, the margins of the segments testaceous; legs pitchy; the coxe and the femora of the list pair; dirty testaceous (Butler). Borly long with ecphialic process 29 - -30 ; cephlalic process 13 and exp. teg. 63 millims.

linported from Iml ial, l'enang : tho Indian Museum possesses a specimen from siklim (?).

3. Fulgora viridirostris, Westiwood.

$\checkmark \quad$ Fulyora (IIotina) virillirost,is, Westwood, Cab. Or. Ent. p. 8, t. 3, f. 4, (18ı).

$\checkmark \quad I I$ tinus virilitostris, Walker, Cat. Ifom. B. Mr. ii, p. 263 (1851).

$\because$ Fulyoru viridirostris, Butler, P. Z. S. p. 98 (187.b).

Cephalic process alont half as long again as tho thorax with tho apex tmined "1) anl acmunato, of a dark green colour with white irrorations; borly fulvous, the thorax spotted with black; fect black with tho forr anterior femora piteliy and tho two hind femora, fulvous : tegmini and wing's marked as in' $T$. candelaria (Westw.). Body with ceplialic proeess long, 32-38; exp. teg. $63-76$ millims.

lieported from Assam: the Indian Musenm possesses specimens from Silssiggar (Assam) and Sikkim, the latter, as a rule, smaller with the cephlalic process of a lighter green and the white irrorations thereon hardly visible.

\section{Fulgora spinole, Westwood.}

: Frulgoru (Py,rops) spinole, Westwood, A. Ar. N. H., ix, p. 118 (1842).

" Fulyora (Intina) spinola, Westwood, Cab. Or. Ent. p. 73, t. 36, f. 1 (18t8).

' ' ILotinus spinulw, Walker, Cat. Irom. B. MI. ii, p. 266 (1851).

F'ulyora spinolu', Butler, P. 'Z. S. p. 98 (1874).

Cephlalic proess as long as tho body with tho apex turning up, alove black, leneath lutcous : hodly fulvous : anterior marghin and tho mildle of the pronotum, a broal median stripe on the mesonotum, two dots and two oblique, lateral streaks, all black : tegmina brown, veins fulvous; three straiglit, transverse, bauds before the middle and six or seven subapical circular spots (of which some form an interrupted maculate hand) pilcly fuscous; wings, fulvous, black at tho apex (Westw.). Body with ceplatic process long 44 ; exp. teg. 82 millims.

Reported from Mysore, Assam, Silhat : the Indian Mruseum possesses specimens from Shillong, Nága hills, Silhat, Sibsígar, and Sikkim.

\section{Fulgora hatimboril, Kirby.}

Fulyorce lathburii, Kirloy, 'I'rans. Linn. Soc. xii, p. 450 (1818); Wrestwood, ibirl., xviii, 1. 139 (1811); White, A. M. N. II. xiv, p. 425 (1811); Gućriu, Icon. Liègruo Au. lus. Ł. 58, f. 2 (1s30-31); lintler, l. Z. S. p. 98 (1874). 
$\checkmark$ () Flata lathlurii, Germar, Thon's Archiv, ii, (2), p. 46 (1830).

$\checkmark$ î IIotinus lgthburii, Walker, Cat. Hom. B. M. ii, p. 266 (1851).

Allied to $F$. camlelaria, Linn., ceplatic process ascending, above black, npex red : dorsum of thornx black: tegmina blackish-grecn, aprinklecl with many ocellato spots having a luteons pupil anil a white iris ; somo white dots on the interior margin : abdomen pallid, spotted black : wings lutcous, black at the apex (Kirby). Long, 38 millims.

Reported from Clina, Silhat.

To this section also belong :-

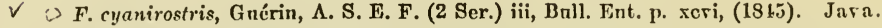

$\checkmark \quad$ F. nigrirostris, Walker, Ing. Sannd. p. 29 (1858). Sian.

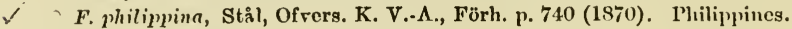

F. rruginosa, Stål, $l$. c. p. 741 (1870). Philippines.

F. lautđ, Stâl, l. c. p. 741 (1870). Plhilippines.

Sec. 2. Species with whitish or white and red wings.

\section{$\checkmark$ o 6. Tulgora connectens, 11. sp).}

Tho coloration of tho tegmina connects this fine species with tho first section and that of tho wings places it in this section. Ceplanlic process numel longer than tho body, ascending, much recurved, somewhat sabreshajed, much compressed, much flattened at the apex, black abore, grecnish-fulvous bencath, signs of faint white irrorations above : thorax black, with a broad, transverse, fulvous band concolorous with the intermediate coxis and the clypeus : abdomen above sordid fulvescent, be. neath black with cach segment brondly bordered posteriorly with sordid fulvesecnt; anus black : feet black, $\operatorname{cox} x$, intermediate femora above, and entire posterior femora, brown: tegmina black, veins greenish; the basal half with threc transverse fulvous bands, of which the third from the base becomes a confluent row of four round fulvous spots, ocellated paler, beyond this in the apical half comes a transverse row formed of two large fulvous ocellated confluent spots near the costal margin and a smaller spot not ocellated near the interior margin, then another interrupted transverso row commencing with four ocellated confluent spots at the costal margin and ending with two confluent ocellated spots at tho interual margin; two large and two small fulvous spots not occllated in the apical fourth : wings white, apex black, with three confluent white spots and two smaller within the black part. Body long to the eycs, 22; cephalic process long from eyes to tip, 30 : exp. teg. 80 millims.

The Indian Museum possesses a specimen from Tenasserim.

\section{$\checkmark$ i) 7. Fulgora clavata, Westwood.}

Fulgora clavata, Westwood, Trans. Linn. Soc. xviii, p. 139, t. 12, f. 1 (1811); Cab. Or. Ent. p. 7, t. 3, f. 1 (1818); Bntlor, P. Z. S. p. 98 (187.t).

$\cap$ IIotinus clatatus, Walker, Cnt. IIom. B. MI. ii, p. 267 (1851). 
Cephalic process and head piceous, covered with a white-farinose substance, as long as half the body, gradually attenuated from the base, its dorsum tricarinate and apex turning upwards and ending in a knob or ball sub-rounded, sub-pellucid, and broadly testaceous : thorax luteous, pronotum with two minute discoidal, black, dots; mesonotum with four basal and two other oblique lateral spots: abdomen beneath fulvous, above obsenre, dotted with a white farinoso substance, apices of segments luteons, anus black : basal half of tegmina somewhat whitish with numerons, irregular fuscous spots; apical half fuscons with numerous whitish circular spots, varying very much in size and most of them ocellated : wings somewhat whitish, apex broadly fuscous : feet and rostrum black; clypeus luteous (Westw.). Body with cephalic process long $33 \frac{1}{2}$; exp. teg. 76 millims.

Reported from Assam: the Indian Museum possesses specimens from Sikkim, Khasiya Hills, Sibságar, Shillong. In fresh specimens the whole of the tegmina and abdomen above and below is thickly covered with a white powdery substance: the abdomen, too, is of a rich red colour, which fades to fulvous, and the wings at the base are a light blue, which fades to grey. The Indian Museum possesses a remarkable local variety from Mussooree in which the entire cephalic process is dull red and the ground of the tegmina is much lighter.

8. Fulgora ponderosa, Stål.

Hotinus ponderosus, Stål, Ofvers. K. V.-A. Förh. xi, p. 241 (1854) : Walker, Cat. Hom. B. M. Suppt. p. 315 (1858).

Fulyora ponderosa, Butler, P. Z. S. p. 98 (1874).

Cephalie process half the length of the body, cylindrical, blackpiceous, ascending at the apex, which is testaceous : thorax and scutellum yellow-testaceous, the latter with four basal spots and two behind the middle, black : tegmina sordid white, sparingly covered with a white farinose substance; a median band spotted with white; and two spots at the anterior margin before the middle and one at the sutural margin, black; several fuscous spots on the disc and apex, which is spotted white: wings sordidly whitish subhyaline, weakly fuscous at the apex: abdomen yellow testaceous, segments margined testaceous : feet and rostrum black; posterior femora yellow-testaceous beyond the middle (Stål). Body long, 38 : exp. teg. 88 millims.

Reported from India. There is little doubt that this is merely a variety of Tr. clavata, Westw.

Sec. 3. Species with red and whitish wings.

$\checkmark$ ? 9. Fulgora oculata, Westwood.

Fulyora oculata, Westwood, Trans. Linn. Soc. xriii, p. 142, t. 12, f. 5 (1811); Butler, P. Z. S. p. 99 (1874). 
$\checkmark$ Var. a. Fulgora (Ilotina) oculata, Westwood, Cab. Or. Ent. p. 73, t. 36, f. 2 (1818).

$\checkmark$ Var. b. Fulgora subocellata, Gnérin, Rev. Zool. p. 183, (1839); Delessert, Souv. Voy. Inde, p. 66, t. 16, f. 1 (1842) ; Butler, P. Z. S., p. 99, (1874).

$\checkmark$ ○ IIotinus oculatus, Walker, Cat. Hom. B. M. ii, p. 267, (1851).

O Hotinus subocellatus, Walker, l. c. p. 267, (1851); J. L. S. Zool. i, p. 84, (1856).

Cephalic process as long as the body, ascending, slender: palc greyish-fulvous, abdomen and wings clothed with a fine white powdery substance, mesothorax more fulvescent : tegmina greyish fulvous, pale, with about twenty-four ocellated spots, fulvous rings girdled whitish : wings white-farinose, palely virescent at the base with the anterior margin having a large roseate patch in the middle cnding in a fuscous spot and another smaller towards the middle: fect palely greyish-lutcous ; four anterior tibio and tarsi and tho last tarsi, black (IVcstw.) Long with cephalic process 35 ; exp. teg. 63 millims.

Reported from India.

$\checkmark$ Var. $a$. Cephalic process as long as the body, ascending at the apex, brunneous; body greyish luteous, powdered with a white farinose substance : tcgmina greyish fulvous, each with $21-30$ fulvous ocellated spots, encircled with buff; wings clothed with a white powdery substance, the base pale green, middle of the costa marked with a large rosy patel and followed by a brown streak which is sometimes extended over the whole apcx of the wing which is, in such case, marked with screral paler spots ; lcgs lutcons, the four anterior tibiæ and tarsi and the two hind tarsi, black (Westw.) Exp. teg. 65-87 millims.

Reported from Malabar, Penang.

$\checkmark$ Var. 6 . Cephalic process as long as the body, ascending at the apex, obscurely ferruginous above, green beneath : body and feet green, anterior and intcrmediate tibiw black; tegmina fulvescent green, suboccllated yellow: wings white somewhat green at the basc, clothed with a white powdery substance and spotted on the anterior margin with black and ferruginous (Guérin). Long, 48 ; exp. teg., 93 millims.

Reported from Nepál, Penang, Malacca. Guérin kecps this separate as he considers that $F$. oculata, West. is smaller, the spots on its tegmina are tawny, very restricted and surrounded by whitish on gi'eytawny ground and its wings are also adorned with a great rosy patch, tipped with brown; characters wanting in his $F$. subocellata. Still comparing the wide differences in the extreme varietics $\gamma^{2}{ }^{2} T$. clavatu this variety cannot at present receive specific rank.

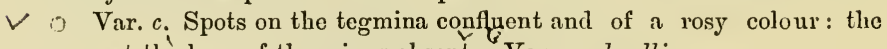
green at the base of the wings absent. ${ }^{G}$ Var. verhuclli.

This section includes also the following:-

Y O F. sultana, $\Lambda$ dams, P. Z. S. p. 83 (1847). Bornco.

$\checkmark$ o F. gigantca, Butler, P. Z. S. p. 99 (1874). Borneo. 


\section{Species with blue-green wings. \\ o 10. Fulgora amplectens, n. sp.}

This species forms the connecting link between the preceding section and this; the coloration of the tegmina strongly resembles that of tho l'. oculata group and the coloration of the wings places it in this section. Cephalic process as long as the body, somewhat horizontal, gradually ascending somewhat towards the tip, subrotundate above and subequal in size throughout, black-brown throughout, above and beneatl, except the tip which is reddish-testaceous and subpellucid, apical half below the tip irrorated with white dots : thorax decp brown, blacker on the disc : abdomen above and beneath, black ; posterior margins of the dorsal segments narrowly fulvous: feet brown throughout: tegmina brown, veins fulvous, basal two-thirds finely covered with a white powdery substance above and bright fulvons beneath, this white powdery substance intensified across the base of the apical third so as to form a white band which bear's a row of four fulvous spots, a small one and the largest towards the costal margin and two small ones towards the internal margin, four or five very faint similar fulvous spots and very numerous light brown spots are sprinkled over the basal two-thirds : wings blue, apex broadly and external margin less broadly, black, rayed black alcng the veins towards the base somewhat as in' F. pyrhorhyncha, Don., to which this species is very closely allied, differing chiefly in the coloration of the abdomen and the size, arrangement, and number of the spots on the tegmina. Body long to eyes, 24 ; cephalic process from eyes, 23 ; exp. teg. 93 millims.

The Indian Museum possesses a specimen from Perak.

\section{11 . Fulgora pyroriyncha, Donovan.}

Fulgora pyrorhynchus, Donovan, Ins. Ind. Hem. t. 7, f. 1 (1800) : Rìgne Animal cl. Masson, t. 96 , f. 2 (n. d.).

$\checkmark \circlearrowleft$ Hotinus pyrorhynchus, Walker, List Hom. B. M. ii, p. 267 (1851); J. L. S. Zool. x, p. $96(1867)$.

$\checkmark$ Fulyora pyrorhina, Westwood, Trans. Linn. Soc. xviii, p. 139 (1841); in Donovan's Ins. lnd. (2nd ed.) p. 13 (181:2).

৮. Fulgora rajah, Guérin, Rev. Zool. p. 183 (1839).

F'ulyora pyrorhyncha, Butler, P. Z. S. p. 100 (1874).

Cephalic process large, of a dark purple, thickly sprinkled with a white powdery substance, ascending, tip scarlet and somewhat pellucid: tegmina brown, pale across the middle; wings black, green at the base (Donovan).

Cephalic process about 25 millims; long, purple, spotted white, ascending; apex incrassated, red; dorsum of abdomen greenish with threc black spots on the anterior margin of each segment; lateral mar- 
gins of thorax and basal margin of scutellum somewhat testaccous: tegmina brown, spotted pale glaueous, and with a paler band, basal half with eleven irregularly placed, round, yellow spots, a pale band with a transverse row of four round spots of a deeper colour approaching fnscous and slightly margined inwardly with yellow and the apical fourth has eight smaller round yellow spots. Guérin describes his $\%$. rajah as having the cephalic process as long as the body, ascending, brunncous, apex somewhat dilated, red: body and fcet brunneous ; tegmina blackish fulvous, spotted with yellow, a broad pallid band at the apex : wings black, blue at the base. Long, 44 millims.

Reported from Nepál (Don.); Malacca (Guér.).

\section{$\checkmark>12$. Fulgora macuhata, Olivier.}

Fulgora maculata, Olivier, Fnc. Méth. vi, p. 568 (17!)1); Stoll, (Tal Cigule verles gorte-lanterne) Cigales, p. 98, t. 26, f. 143 (1788) ; Burm. IIndb. Ent. ii, (i) p. 16!) (1835); Westwood, Trans. Linn. Soc. xviii, p. 140 (1841); Dnncan's Nats. Lilb. 1, p. $2 S$ t, t. 23 , f. 2 (1840); Batler, P. Z. S. p. 100 (1874).

$\checkmark$ S Flata maculata, Germar, Thon's Archiv. ii, fasc. 2, p. 46 (1830).

$\checkmark>$ Hotinus maculatus, Walker, Cat. Hom. B. M. ii, p. 266 (1851).

Cephalic process almost as long as the body, ascending, recurved; head black; eyes and antennæ grey ; thorax brown, shaded with black: abdomen light brown, banded with black, same above and beneath; tegmina above black with interrupted bands or continuous rows of glaucous spots, apical portion irrorated yellowish-green: wings with the basal portion towards the anterior margin and a patch near the anal margin, greenish-blue ending in fine rays, apical portions black: feet deep brown, posterior pair spinose. Body long to the eyes, 21 : cephalic process from the eyes 19 ; exp. teg. 71 millims.

The Indian Museum possesses a specimen from Ceylon.

\section{l. 13. Fulgora fultirostris, Walker.}

\section{Hotinus fulvirnstris, Walker, List Hom. B. M. Suppt. p. 41 (1858).}

Butler (P. Z. S. p. 100, 1874) unites this species witl F. maculata, Olivier, as a variety, but it is as much entitled to specific rank as brevirostris, viridirostris, and spinolo, which are similar varicties of $F$. candeleria, Linn. It clearly differs from $F$. maculata in having the ecphalic process subpellucid, sordid fulvous-testaceous or tawny instead of opaqne deep green; the markings on the tegmina follow the arrangement of the markings on the tegmina in $F$. maculata, but are sordid whitish instead of bluish-white, and the wings are sordid greenish-white rayed with black-fuscous nearly up to the base, the apex being broadly and the external margin less broadly black. 
Black : head tawny, cephalic process abruptly curved and ascending, a little shorter than the body, blackish on each side, at the base : pronotum with sone dingy whitish or testaceous marks on each sido: mesonotum more or less testaceous or whitish on the dise; hind border and abdomen whitish or testaceous, the latter with some irrogular and incomplete blackish bands : tegmina with aloout 20 whitish or straw-coloured spots and dots, some of them connected, forming four very irregnlar lands: wings white or dingy whitish towards the base (Walker). Body long, 27; ecphialic process from the eyes, 20 ; exp. teg. 59 millims.

Reported from Ceylon: the Indian Museum possesses two speeimens from Ceylon. It is possible that we should place this and the two next as varieties of $F$. maculata.

\section{1.t. Nulgora delesserti, Guérín.}

Fulyora delessertii, Gnérin, Rov. Zool. p. 183 (1839); Delessort, Sonv. Voy. Inde, jt. ii, p. 6(i, t. 16, f. 2 (18+3): Butler, P. Z. S. p. 100 (187t).

b. () Hutinus detessertii, Walker, Cat. Hom. B. M. ii, p. 266 (1851).

Cephalic proecss half the length of the body, ascending, green : prothorax ferruginous : tegmina greenish black, spotted with yellow : wings courulean, black at llie apex (Guérin). Long 34; exp. teg. 75 millims.

Reported from the Nilgiris, Malabar.

'Ilis species is near to $F$. maculata, Olivior, but diffors from it in the coloration of the spots on the tegmina. It differs from ${ }^{\circ}$. candelaria, linn. "pill les deux facettes latérales de la face frontalo qui ont à leur extrénité une curène longitudinale allaut du sommet des faces latérales au sommet de la tête." 'l'he ecplialic process is short and compressed.

\section{5 . Fulgora andamanensis, Distant.}

Fulgora andamamensis, Distant, Trans. Ent. Soc. p. 152, t. 5, f. 7,7 a (1880).

Geplialic process long, slender, ascending, as long as tho body; beneath greenish lnteons with the apex black, above black, apical twothirds irrorated with small white spots and a luteous streak on each side within the eyes, which are also luteous; thorax above black, with dull lnteous markings; aldomen above pale greenish-lnteons, bencath black; cosic, trochanters, and femora fuscous, the last darkest, tibio and tarsi, Mlack. T'egmina black, " with the veins pale green and a number of lnown spots encircled with palo greenish, arranged thus:-a transverse row of four near the base, the upper three fused together; two irregular transverse rows on the dise, a little nearer together than from the basal row, followed hy a straighter transverse row of three smaller ones; r'maining apieal portion oceupied by about twelve spots of which the largest are two fused together on the costa and one with a very small 
brown centre about the apex of the imer margin : extreme apieal spots very small and somewlat indistinct. Wings blue with the apex broadly, and onter margin somewhat narrowly, black. The veins on the bluo pertion of the wings are grecn, with the exeeption of two which are nirrowly black at the base (Distant.) Long, ceplalic process 20; bocly 20 ; exp. teg. 68 millims.

Reported from the $\Lambda$ udaman Islands.

Allied tô F.delessertii, Guérin, and F. maculata, Olivicr. It somewhat resembles the former in the pattery of, the tegmina, but differs in the length of the cephalic process, which in $F$. delessertii is but abont half the length of the body. In length and structure of the ecplialic process, it is more closely alliced to $\mathrm{F}$. maculata; the cephalie process, howerer, is longer than in that species, being abont equal to the length of the henly ; ancl, hesides the different patteru of tho tegmina, lhe wines sure much mere narrowly black along the posterior margin. 'Tho Lutian M/nsem pussesses a specinen from the Nicobar islands which appears to diller from the type figured by Distant in the ecplıalic process being longer, more clistinclly aseending and recurred, and in the absence of white spots on the "1per two-thirds. The markings on the tegmina are the same and do not differ more than individuals of allied species differ from each other. Tho wings are marked much as in $F$. delessertii Ginéri:ı, the outer matgin is more broadly suffused with blackish than in the type and tho blackish extends further towards the base in rays.

\section{J 16. Fulgora curtiprora, Butler.}

Fulyora curtiprora, 13utler, $\Lambda$. M. N. H. (4 ser.) xiv, p. 131, (1871).

Closely allied to $r$. gemmata, West., lut with the cephalic proeess one-third shorter and the colouring different: tegmina with the corinm bright green speckled with black, area beyond black; the veins green, becoming ochraceous near the apex; entire surface covered with small orayge spots: wings shining black, varied with pale transparent green as in I'. gemmata: cephalic process, head, and thorax testaccous, thomx spotted with black; abdomen black, segments edged with green above, with ochreons below; legs and anus red (Buller). Borly long with cephalic process, 23 ; cephalic process, long $8 \frac{1}{2}$; expl. teg. 50 millims.

Reported from Sikkim.

\section{$\checkmark 17$. Fulgora guttulati, Westwood.}

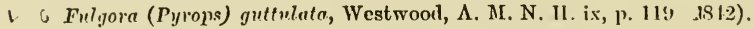

l. O Fulyora (Hotina) guttulata, Westwood, Cab. Or. Wint. p. 8, t. 3, f. 3 (1sis).

V. Pyrops guttulata, Walker, List Hom. B. M. ii, p. 269 (1851). Fulgora guttulata, Butlor, P. Z. S., p. 101 (1871). 
Cephalic process about half as long as the thorax, its apex slightly bent upwards and acute; head and thorax above of a fulvous clay-colour dotted with black: segments of the abdomen brown at the base : tegmina pale fulvons clay-coloured, gradually assuming a redder tinge beyond the midile with a great number of small pale buff dots edgred with a black ring, the wings very palo yellowish, with a few black dots and a broad dark brown margin (Westw.) Body long with cephalic process, 25 ; exp. tog. 50 millims.

Reported from N. India.

The rostrum is very long and slender and extends to the end of the body, separated from the gens by a transverse raised line, between which and the eyes is a black dot. Tho fonr anterior legs have a black ring at the base of the tibia, the apex of which and the tarsi are also black, the underside of the body and the hind legs are entirely fulvous with two small black spots at tho base of the coxæ and two long black spots at the sides of the penultimate abdominal segment.

\section{ᄂ. 18. Fulgora gemmata, Westwood.}

Fulgora gemmata, Butler, P. Z. S. p. 101 (1874).

Head and thorax fulvous with black markings; abdomen above black with posterior margins of the segments narrowly green; tegmina green at the base which gradually changes into a dark brownish crimson; they are entirely covered with minute black dots, each tegmen being ornamented with about 30 bright orange spots; the wing's are green, with a broad black border, which extends into the disc of the wing, forming several large, black blotches; legs, dark red (Westw). Body long exchusive of cephalic process, 19 ; exp. teg. 28 millims.

Reported from IIimálaya, N. India, Darjiling : the Indian MInseum possesses specimens from Sikkim, Khasiya IIills, Assam. There is also a specimen in which the orange spots on the tegmina are obsolete and aro replaced by romudish black rings with the centre of the ground colour of the tegmina; the wings are precisely the same.

To this section also belong the following species :-

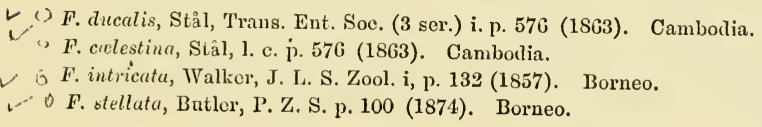


Sec. D. Species with scarlet wings.

19. Fulgora cardinalis, Butler.

Fulgora cardinalis, Batler, A. M. N. H. (4 ser.) xiv, p. 131 (1874).

Tegmina yellowish-olivaceous, veins and costal area bright green ; entire surface covered with black-edged orange spots, arranged as in $\sigma F$. virescens, West., but larger and better defined ; outer margin brown : wings carmine; outer margin brown, broadest at the apex : eeplatic process, head and prothorax above, and the entire pectus green, spotted with black; meso- and meta-thorax testaceous, black-spotted; abdomen above reddish, below testaceous, varied with emerald-green : legs emerald-green (Butler). Borly including cephalic process, 25 ; ecphalic process $8 \frac{1}{2}$ : exp. teg. 53 millims.

Reported from Nepál, Sikkim. Allied to F. pyyrhochlora, Walker, and $F$. virescens, Westw., but differing strueturally from both in its short abruptly compressed cephalic process. The Indian Museum possesses specimens from Sikkim.

To this section also belong the following species:-

1. F. coccinea, Walker, List Hom. B. M. Suppt. p. 42 (1858). Coylon.

V $\circ$ F. decorata, Westwood, Trans. Linn. Soc. xviii, p. 111, t. 12, f. 4, (1841). Jara.

$1 \quad$ F. guttifera, Stål, Ofvers. K. V.-A., Förh. p. 448 (1859). Ceylon, Shanghai ?

F. Fyrrhochlora, Walker, Batler, P. Z. S. p. 101 (1874). Borneo.

Sec. E. Species with pale greenish wings (subhyaline).

1. 20. Fulgora virescens, Westwood.

Fulgora (Pyrops) virescens, Westwood, A. M. N. II. ix, p. 119 (1812).

Fulgora (Hotina) virescens, Westwood, Cab. Or. Ent. p. 8, t. 3, f. 5 (1818).

$\checkmark$ \& Pyrops virescens, Walker, Cat. Hom. B. M. ii, p. 209 (1851).

$\checkmark$ o Hotinus semiannulus, Walker, l. c. Suppt. p. 42 (1858).

Fulgora virescens, Bntler, P. Z. S. p. 102 (1874).

Cephalic process short, conical, searcely bent upwards: entirely pale green with a minute black spot on each side of the prothorax and seutellum; the tegmina broad with the anterior margin much arehed, green with numerons small rounded orange-coloured spots, outwardly edged with black; wings very pale green and semitransparent (Westw.). Body long with the cephalic process 19-20: exp. teg. 56-58 millims.

Reported from India, Silhat: the Indian Muscum possesses a specimen from Silhat.

To this section also belongs the following species :-

F. cultellata, Walker, J. L. S. Zool. i, p. 143 (1857). Bornoo.

14 


\section{Alcatnous, Stål.}

Trans. Ent. Soc. (3 Ser.) i, p. 577 (1863).

Head much narrower than the thorax, protuberant, frons somewhat roundly-amplified near the apex, thence distinctly narrowed upwards, tricarinate; clypens carinate in the middle: rostrum almost reaching the apex of the abdomen : antennæ short, second joint very briefly subcylindrical, obliquely truncated at the apex. Thorax unicarinate in tho midlle, somewhat prodiced anteriorly in the middle, produced part truncated, posterior margin, straight: scutellum tricarinate, twice as long as the thorax. Tegmina somewhat amplified towards the apex which is obtusely obliquely rounded, longitudinal veins rarely furcate, interior simple, only third apical part furnished with remote, transverse, small veins, irregularly anastomosed: wings with more than the basal half without trausverse veinlets. Feet moderate, anterior femoyg beneath slightly dilated, posterior tibia, 5-6 spinose (Stål). Allied to Fulgora.

\section{( 21 . Alcathous fecialis, Stål.}

Alcathous feciulis, Stål, 'Trans. Ent. Soc. (3 ser.) i, p. 577 (1863).

Livid, dor'sum of abdomen and cocineous wings excepted, minutely sprinkled fuscous, here and there infuscate: tegmina clouded fuscous with small costal spots, apex of wings, broad posterior limbus and some spots near the anal area, two rows of spots on the dorsum of the abdomen and rings on the tibir blackish; femora fuscescent, obscurely irrorated, banded palely. $\$$, long, 15 ; exp. teg. 32 millims.

Head a little shorter than the thorax and scutellum together, produced part somewhat subabruptly narrowed and compressed before the eyes, before the middle transversely impressed and somewhat reflexed; vertex at the base more than twice as broad as the transverse eye, basal half triangular, apical part very narrow ; frons flat beneath the middle, furnished with three parallel ridges, the median ridge interrupted in the midcle; transverse veinlets on the tegmina are subrufescent (Stål).

Reported from $\mathrm{N}$. India.

\section{Genus Prrops, Spinola.}

A. S. E. F. viii, p. 231 (1839); Am. \& Serr., Hist. Nat. Ins. Hém. p. 491 (1843) ; Stål, Hem. Afric. iv, p. 133, 139 (1866).

Head produced forwards, in a long process, somewhat rounded, gradually very slightly somewhat slender, straight, obliquely truncated at the apex; the lateral part behind the oyes furnished with a subconical or triangular callus or knob; vertex transversely convex, continued up to the apex of the process; genw rounded anteriorly: eyes small; 
second joint of antennæ slort, thick. Pronotum and scutellum fairly convex transversely, witlout ridges, the former gradually narrowed forwards, barely or very slightly sinuated at the base. Entire tegmina or the largest portion reticulated, valvate behind the clavus. Fect somewhat thick and short; first tibix, femora, and trochanters togethor equal in length, last armed with $5-7$ spines (Stål).

\section{$\checkmark$ o 22. Prrops pUnctata, Olivicr.}

c. Fulgora punctata, Olivier, Enc. Méth. ri, p. 569 (1791); Stoll, Cigales, p. 34, t. 6, f. 28 (1788) ; Gray, Grifith's An. King. t 138, f. 2 a.c (1832).

$\checkmark$ C Flata punctata, Germar, Thon's Archiv. ii (2), 1) 47 (1830).

- Fulgora affinis, Westrood, Trans. Linn. Soc. xviii, p. 14t, t. 12, f. 6 (1811).

Pyrnps punctata, Spinola, A. S. E. F. viii, p. 237 (1839); Walker List IIom. B. M. ii, p. 268 (1851).

Cephalic process almost as long as the body, truneated at tho apex; luteous-greyish; thorax, feet, and tegmina sprinkled with black dots : abdomen above black: wings white, veins pallid. Head, cephalic process, pro- and meso-notum and tegmina pale luteous, sprinkled with black dots, varying in size : cephalic process almost as long as the body, almost straight, subcylindrical, obliquely truncated at the apex, fuscousluteous, rongh with dots, paler at the apex: the black dots on the tegmina disposed longitudinally on the veins: wings white, subopaque, a little infuscate towards the apex, veins paler, except at the base: abdomen black, with the narrow margin of the segments, luteous; fect short, luteous; femora with a subapical ring; tibir with three black rings (F. affinis, Westw.). Body long with cephalic process, $33 \frac{1}{2}$; exp. teg. 55 millims.

Reported from China, Nepál, Silhat, Ceylon, Java, Guinea (?) : the Indian Museum possesses specimens from Sikkim.

\section{Prrops perpusilla, Walker.}

Pyrops perpusilla, Walker, List Hom. B. M. ii, p. 269 (1851).

Body stramineous; head with its process as long as the rest of the body; abdomen luteous above: legs yellow; tegmina very pale stramineous; a few brown dots on the veins near the tip and along the hind border which is somewhat darker than the rest of the wing; a rather large dot in the dise on the fork of one of the longitudinal veins : wings colourless, veins pale yellow (Walker.) Boly long $8 \frac{1}{2}$; wings, long 9 millims.

Reported from N. Bengal,

16 


\section{- Genus Homalocepinala, Amyot \& Seville.}

Omalocephala, Spinola, A. S. E. F. viii, p. 261 (1839): Homalocephala, Am. \& Serv., Hist. Nat. Ins. Hém. p. 492 (1813) ; Stål, IIem. Afric. iv, pp. 133, 1.15 (1866).

Head broal, somewhat narrower than the thorax, produeed before the eyes, round or triangular; behind the eyes prominulous backwards in a short, thick spine : vertex at least four times broader than the eyes, flat or somewhat so : frons flat somewhat broader than the clypeus, sides parallel, very slightly amplified towards the apex; clypeus without a median rilge: rostrum reaching the last coxœ. Thorax broadly rounded anteriorly, furnished with a fine longitudinal ridge : sentellum more than twice as long as the thorax. Tegmina with the sicles parallel, obliquely obtusely rounded at the apex, very densely reticulated, reticulation in the costal area obsolete, clival vein united with the commissure at the apex of the clavus : wings entire. Feet somewhat short, simple; first tibire as long as the femora, last armed with $3-4$ spines (Stål).

\section{$\checkmark$ is 24. Homalocepinala festiva, Fabricius.}

()Fulgora festiva, Fabricius, Spec. Ins. ii; p. 315 (1781); Mant. Ins. ii, p. 261 (1787) ; Olivier, Enc. Méth. vi, 1). 572 (1791); Fabr., Ent. Syst. iv. p. 5 (1794); Syst. lihyug. 1. 4 (1803); Donovan, Ins. India, Hem. t. 7, f. 2 (1800).

$\therefore$ Omalocephala jestiva, Spinola, A. S. E. F. viii, p. 261 (1839); Walker, List Hom. B. A. ii, p. 283 (1851).

Homulocephala festiva, Am. \& Serv., Hist. Nat. Ins. Hém. p. 493 (1813).

Head above flat, fuscons; beneath flavescent, with a black margin : thorax fuscous, immaculate: tegmina fuscous, exterior margin virescent, which colour, however, does not reach the apex of the wing : there are five black dots along this margin of which the four posterior end inwards in it fulvous dot: wings sanguineous, fuscous at the apex (l'abriciuss).

Ifead above flat, obsenre; beneath, yellowish, border black: thorax obscure inmaculate: tegmina obscure with the costal margin greenish which does not extend to the apex, on this part are five black spots of which the fonr posterior are bounded internally by a tawny spot: wings sangunineons with the apex obseure (Olivier). Donovan states that the tegmina have a green margin on which there are a few black spots semicircled with orange. Long, 17 millims.

The Indian Musenm possesses a very mutilated specimen.

$$
\text { L. ) Genus Limors, Stål. }
$$

Stettin Fint. 'Zeit. xxiv, p. 230 (1863): Hem. Afric. iv, p. 134 (1866).

Ifead narrower than the thorax, slightly protuberant upwards; frons longitudinally convex, abruptly dilated on both sides at the apex, 
much narrowed upwards, bicarinate lengthways, lateral margins reflexed beneath the middle; vertex transverse; clypeus carinate in the middle, lateral margins obtuse, obtusely carinate; thorax twice as broad as the head, somewhat sloped forwards, broadly truncate posteriorly, obsoletely carinate in the middle: tegmina somewhat amplified towards the apex, which is obliquely obtusely rounded, furnished behind the middlo with remote small transverse veins: wings sinuate in the middle, posteriorly, much shorter than the tegmina : fect moderate, simple; posterior tibix 5-spinose (Stal). Differs from ${ }^{\circ}$ Apllana in the structure of the head and the short wings.

\footnotetext{
$\checkmark \quad 0$ 25. Limois WeSTwoodil, Hope.

Lystra vestivoodii, Parry, Hopo, Trans. Linn. Soc. xix, p. 133, t. 12, f. 3 (1845) ; Walker, List Iom. B. M. ii, p. 286 (1851).

Limois vestwoodii, Stỉ, Stettin Ent. Zeit. xxir, p. 231 (1863).
}

Fuscous yellow, cephalic process concolorons, recurved between the ejes; frons almost triangular, elongate: basal half of tegmina fuscous yellow, sprinkled with fuscous spots, varying in size : wings at the base sauguincous and margined by a narrow black line and with three black spots, remainder immaculate, hyaline: body beneath black. (Hope.) Body long, $12 \frac{1}{2}$; exp. teg. 48 millims.

Reported from Silhat: the Indian museum possesses a syecimen from Calcutta, expanse of tegmina under 40 millims.

\section{* Genus Aphans, Guérin, Stål.}

४ O Aphena, Guérin, Voy. Bélanger, Ind. Orien. p. 451 (1831); Spin., A. S. E. F. viii, p. 240 (1839) : Aphana, Burm., Handb. Ent. ii (i) p. 166 (1835); Amyot \& Serville, Uist. Nat. 1ns. IIém. p. 496 (1843) ; Stål, Stettin, Ent. Zeit. xxiv, p. 231 (1863) ; Hem. Afric. iv, p. 134 (1866).

Head not protuberant; frons slightly narrowed upwards or with the sides parallel, lateral margins more or less distinctly broadly bisinuate with two ridges running through them, diverging upwards from the apex, terminating on both sides the meclian aren: thorax with a ridge very often much elevated: first femora not amplified above at the apex; last tibie usually 5 -spinose, unarmed above at the base (Stål).

\section{$\checkmark 0$ 26. Aphana farinosa, Fabricins.}

¿ O Lystra farinosa, Fabricins, Syst. Rhyng. p. 57 (1803): Germar, Thon's Archiv, ii (fasc. 2) p. 52 (1830).

$\checkmark$ Aphrena farinosa, Spinola, A. S. E. F. viii, p. 244 (1839) ; Walker, List Hom. 13.

I. ii, p. 274. (1851).

$\checkmark$ O Aphana scutellaris, White, A. M. N. II. xvii, p. 330 (1846). 
Aphrna scutellaris, Westwond, Cab. Or. Ent., p. 73, t. 36, f. 3 (1818); Walker, List H1m. B. M. ii, 1, 277 (1851)); J. L. S. Zool. i, p. 143 (1857) ; var. 1. c. x, p. 96 (Isiit).

"A Alurna sanulersii, Walker, List IIom. B. M. ii p. 277 (1851) ; J. L. S. Zool. i. p. 81. (1siti) ; 1. 6. p. 1.1:3 (1857).

L. Apruun furinosu, liurm., Ifundl,. Ent. ii (2), p. 166 (1835); Stål, Ofvers. K. V.-A.

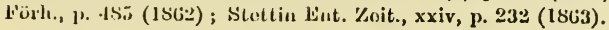

linscous; tegmina yellow at the apex; baso of tho wings and tho alulomen, red, the former spotted hyaline ( $r a b r$.$) . Head, pronotum, and$ border of the tegmina, reddish-brown, the under half of the same black, apex golden yellow, powdered white: wings with a red grommd wijh small white spots; tip brown: feet, black (Durm.). Larger tliai 1. utomariu, liahr. greenish-brown; occiput excavated and marked will two whitish powitery spots between the oyes; the pronotum with an clevated ridge down the mildle, the scutcllum powdered with white, the netallomax blackish; the margins of the abdominal segments luteousgreen, the hase powdered with white; the basal half of the tegmina ferrogimus, the dise powdered with white, and with an irregular black fiscia in the milllle and some blackish spots near the hind margin, the aprical portion loru-colomed, varied with bnff, hind-wings orange reel, spottel with white, the base black, the apical portion hom-colomed, aud the amal angle bulf; looly heneath, and legs, pitchy (Westwooul). Bocly long, a.2 ; exp. teg. 5)!-66 millims.

lieported from 13orneo, Java, Sumatra, India (Spin.): the Indian Mruscum las a much abraded specimen from Sinkip Islaud. The type describul hy White was from Borneo and varies in the green colour of lle bisal portion of the costa and the base of the tegmina. Westwool's sjecincu was from Java and the Indian specimen agrees best with his descriptim.

\section{$\checkmark J$ 27. APIANA atomaria, Weber.}

Cicalu atomaria, Weher, Ohs. Ent. p. 113 (1801).

Lystra atomaria, Faluricins, Syst. R!yng., p. 57 (1803); Gormar in Thon's Arehiv. ii (fitsc. 2), p. 52 (1830).

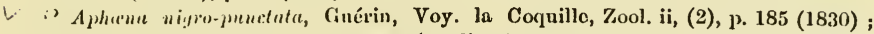
Sprin., A. S. W. W. (1 sír.) viii, p. 218 (1839); Am. \& Serv., IIist. Nat. Ins. IIém. p. 1:37, (1813); Walker, List. IIom. B. M. ii, p. 274 (1851).

() Aphur atomatic, Spin., l. c. p. 218 (1839); Walker, 1. c. p. 277 (1851); J. L. S. Zool. $x$, ]. り6 (1867).

- Aphana atomarin, Bnrm., IIandb. Ent. ii (i) p. 167 (1835); Stål, Stettin Ent. Zeit. xxiv, p. 232 (18(33) ; Ilcm. Fabr. ii, p. 87 (1869).

Fuscous, vertex and pronotum brick-colour : tegmina ferruginous, spotted black, abdomen above and wings sanguineous, the latter black ai the apex and spotted black-hyaline (Fabr.). Head and pronotum 
ochreous; mesonotum rechlish-brown : tegmina of a red brown in the basal two-thirds with two large black spots on the exterual margin, another towards the end of the second third, in the micldle; two other smaller black dots, one at the base and tho other towarls the end of the first thirel near the internal margin, and other smaller black dots sprinkled here and there : the apical third of the tegmina sordicl yellowish or dull brown: wings bright red with the apex black, sprinkled with bluish spots or patches, the red disc also has four white patelies, of which one is rery small, with some dozen round black dots strewn about behind them : abdomen red above : body and feet, beneath, reddish-brown ( $1 \mathrm{~m}$. \&. Serv.) Long, 17 ; exp. teg. 46 millims.

Reported from Sumatra, Java, N. India: the Indian Museum possesses one abraded specimen exactly agreeing with the above desscription, locality nnknown, and another from Marri (P'aujalı). 'T'here is a series from Sikkim agrecing in most respects except that the base of the wings is ochrcous not sanguincous.

\section{$\checkmark$ 28. Aphana pulchella, Guérin.}

$\checkmark$ O Aphanna pulchella, Guérin, Voy. la Coqnille, Zool. ii (2), p. 189 (1830); Spinola, A. S. F. F. viii, p. 29.4 (1835); Walker, List Hom. B. M., ii, p. 274 (1851); Stâl, Ofvers. K. V.-A., Förh. p. 485 (1862); Java.

D. Aphana confucius, White, A. M. N. H. xviii, p. 24 (1846) : China.

$\checkmark \bigcirc$ Aphrna confucius, Walker, l. c. p. 280 (1851): China.

ᄂ c Aphena io, Walker, List Hom. B. M. ii, p. 279 (1851) : N. India.

1 ) Aphana nigro-irrorata, Stål, Ofvers. K. V.-A. Förh. f. 2 \& (185t) : Chimn.

$\checkmark \quad$ Aphurna nigro-irrovata, Stàl, Freg. Eng. llesn, Ins., p. 270 (1859) : Ilong-Kong.

$\checkmark$ Aphana pulchella, Stàl, Stettin Ent. Zeit., xxiv, p. 232 (1863).

$\checkmark 乞$

Smaller than 4 . atomaria, Fabr., from which it differs in not having the head and thorax yellow, by the tegmina spotted with irregular black dots and the feet yellowish, annulated blackish. Head pro- and meso-notum yellowish punctured grey; metanotum and abdomen vermillion, two small black spots on the former and weak black bands on the three first segments of the abdomen, which also show traces of being covered with a white cottony substance : liead and thorax beneatl of a fairly deep yellowish-brown with a white patch between the intermediate and posterior coxø : abdomen bencath ochreous yellow, punctured black, the lateral margin of each segment with a black excavation, filled with a white powdery substance; feet brown, ammulated yellow. Tegmina of a somewhat faded saffron-yellow, semitransparent, nore yellow towards the apex, covered with numerous small black dots, a few larger; towards the tip and the interior margin a whitish quadrate spot, followed at the posterior and external angle by a brown patcli confluent with the small black dots of the apex : wings vermillion, carmine 
towards the base and a little orange in the middle and on the side of the anterior border: tip with a large black patch, adorned with small blue spots; posterior margin slightly infuscate and disc with $16-17$ small, nearly equal, black spots and four small white spots placed in the orange portion (Guérin). Long, 15 : exp. teg. 37 millims.

The Indian form (A. io, Walker) is thus described :-

Body yellowish-brown; hcad and mesonotum punctured black, carinate; rostrum brown, as long as the body ; metanotum, red ; abdomen bright red; beneath, spotted black with a black stripe along each side and a brown posterior margin on each segment: legs black, femora and tibio flavo-annulate, posterior tibir spinose: tegmina yellowisllbrown with numerous black marks which are confluent and form a black spot at the tip of the hind border; this spot has a yellowish-white spot adjoining; wings luteons, red at the base and along the inner border, with about 12 black and 4 white spots, brown along the hind border, terminating in a very large black spot which has a blue dise (Walker). Body long, $16 \frac{1}{3}$; exp. teg. 46 millims.

Reported from China, Java, India: the Indian Museum possesses specimens from Sikkim and the Andamans.

\section{Apilana variegatia, Guérin.}

- Aphena variegata, Guérin, Voy. Bélanger Ind. Orien. Zool. p. 455 (1834); Icon. Règne Anim., t. 58, f. 3 (1830-34); Spin., A. S. E. F. viii, p. 247 (1839); Walker, List Hom. B. M. ii, p. 278 (1851).

$\checkmark$ O Penthicus variegatus, Blanchard, Hist. Nat. Ins. iii, p. 171, Hém. t. 12, f. 4 (1810-41). $\vee \quad$ A phuna basirufa, Walker, List Hom. B. M. ii, p. 278 (1851) : J. L. S. Zool. i,
p. 143 (1857).

$\checkmark$ Aphana variegata, Am. \& Serv., Hist. Nat. Ins. Hém. p. 497, t. 9, f. 1 (1813); Stål, Stettin Ent. Zeit, xxiv, p. 232 (1863).

Head flat in front, with two slightly elevated ridges: pronotum transverse, anterior border lobed and a little advanced, carinate in the middle, with a hollow on each side behind the median lobe, and a little emarginate posteriorly: mesonotum triangular, sides almost equal, pointed behind, tricarinate in the middle, one ridge longitudinal, and two lateral, curved : metanotum and abdomen bright red, separated by a white, farinose, transverse band ; the head, pro-, and meso-notum brown, touching on deep olive-green. Tegmina brunneous, a little reddish at the base, more greenish at the tip with black patches and round black dots which increase in size towards the apex; two square yellowish patches at the middle third, one on the anterior, the other on the interior margin: wings much broader, a little sinuated on the posterior margin; the base up to one-third of their length bright red with three 
black spots and an obscure patch ; middle third orange yellow grounded with red, above 2-3 small white dots and below a small black spot: the apex is black with more or less numerous or confluent small blue dots; posterior margin from this black portion to the internal angle is broadly bordered brown. Body beneath concolorous with the thorax, feet more blackish (Guérin). Long, 20 ; exp. teg. 55 millims.

Reported from Cochin-China, Philippines, Silhat: the Indian Museum possesses specimens from Sikkim.

\section{$\checkmark$ o 30. Aphana CAJA, Walker.}

- Aphena caja, Walker, List Hom. B. M. ii, p. 278 (1851).

Aphana caja, Stål, Stettin Ent. Zeit. xxiv, p. 235 (1863).

Fuscous-ochraceous; thorax palely gramulate towards the sides; tegmina fawn-colour or palely olivaceous, clonded with black-fuscons and sprinkled with minute black-fuseous spots, further, behind the middle, adorned with a pallid subquadrate spot at the costal and commissural margins: wings croceous, sanguineous at the base, a small oblique, basal streak and 5-7 spots in anal half, black-fuscons; $3-4$ small white discoidal spots in the anterior area; posterior limbus warrowly fuscons; apical part black-fuscons, sprinkled with glauconsmouldy spots; abdomen sanguineous, dorsum with a double row of black spots, beneath fuscous-sanguineous: feet spotted olivaccous. o, long 21 ; exp. tog. 62 millins.

Nearly allied $0_{0}^{8} 4$. variegata, Guérin, but larger, spots on the tegmina larger, wings sanguineous only at the base, posterior fuscons limbus narrower and especially with the vertex shorter, nearly thirice broader than long, more obtusely rounded, transverse basal keel straight, anterior margin less decply sinuate in the middle: frons subequal at tho base and the apex, not distinctly narrower at the base, anterior produced part of thorax more obtusely rounded. Frons somewhat longer than broad, lateral margins slightly broadly bisinuate, with two obtuse ridges diverging upwards and with an obsolete longitudinal ridge towards the base, the median area at the base very broadly rounded: thorax marked before the middle with two obsolete pallid spots (Stål).

Reported from Silhat.

\section{$\checkmark \gamma$ 31. ApHana dimidiata, Hope.}

$\checkmark \quad$ L Lystra dimidiata, Iope, Trans. Linn. Soc. xix, p. 133, t. 12, f. I (1815); Walker, List Hom. B. M. ii, p. 286 (1851). A phana dimidiata, Stål, Stettin Ent. Zcit. xxir, p. 232 (1863). 
Fuscons ; head, thorax, and fect concolorons: basal half of tegmina virescent, sprinkled with numerous minute dull black spots, apices suborange-hyaline marked with cretaceous spots : basal half of wings g'reenish with the posterior part whitish, spotted black, apiees fuscous, irro-

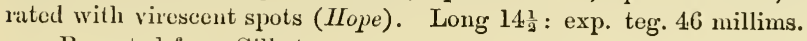

Reported from Silhat.

\section{$\checkmark \quad 32$. Aphana nicobarica, Stål.}

Aphana nicobarica, Stål, Berlin Ent. Zeitschr. xiii, p. 241 (1869).

Sordid olivaceous-green : scutellum, pectus, abdomen, and feet black-fuscous: tegmina before the middle æruginous, sprinkled with blaek; behind the middle, ochraceons, marked with a band and mouldy spots; apical limbns, black; wings, black, a very large basal spot cornlean-vireseept. Long 19 ; exp. teg. 55 millims, + .

Size $6 \mathrm{f}^{\circ}$ A. farinosa, Burm., from which it differs in the head prodnced anteriorly, seen from above equal in length and breadth between tho eyes, roundly-angulated; frons longer, furnished with a recurved process. Frous rugulose, tumescent at the base and with a median process short, compressed, recurved, obsoletely tricarinate, the ridges diverging upwards, the median ridge disappearing below the middle: vertex narrowed forwards, obsoletely carinate in the middle; lateral margins dilated, elevated: thorax furnished with a raised, acnte ridge, ruming through it, strongly bi-impressed on the disc, scutellum tricarinate. The arnginous half of the tegmina covered with minute and often confluent black dots, closer at the apex; apical half ochraceous with the apieal limbus black; the spots and an anterior band elothed with a white powdery substance: wings black with a large basal patch extended a little beyond the middle, cærrulean-virescent. Apical margins of the dorsal segments of the abdomen, green (Stal).

Reported from the Nicobars.

\section{Aphana (?) Dives, Walker.}

$\checkmark$ Aphana dives, Walker, List Hom. B. Mr. ii, p. 280 (1851).

Body dark ferruginous; disc of the vertex rather concave, borders slightly ridged, fore margin slightly inclined upwards : rostrum extending far beyond the posterior coxæ, dark brown: mesonotum with a slight longitudinal furrow, fore-border very undulating; a black band along the fore-border of the scutellum; metanotum black: abdomen obconical, larger than the thorax, black above, thickly covered with white down, red beneath : legs black, sulcated, femora brown, posterior tibie spinose : tegmina green, adorned between the veins with orange streaks which are interrupted by very numerous brown dots, the latter are 
sometimes confluent; a tawny slightly curved band scparates this part from the reticulated tips which are brown with tawny veins: wings green, with numerous brown spots, gray mingled with white towards

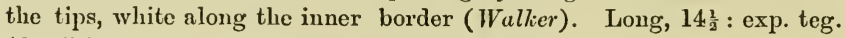
42 millims.

Reported from Malabar.

\section{$\checkmark$ o 34. Aphana (?) albiflos, Walker.}

\section{$\checkmark$ Aphena albiflos, Walker, List Hom. B. M. ii, p. 280 (1851).}

Body above, green ; beneath, bright-red ; vertex tawny, indistinetly carinate along the border; face slightly carinate; rostrum nearly as long as the body, tip black; a concavity corresponding to the eye on each side of the fore-border of the pronotum of which the anterior portion of the lateral margins is black, posterior margin, tawny ; longitudinal ridge almost obsolete : abdomen obeonical, much longer than the thorax, thickly covered with white down: legs ferruginous, suleated; femora, red; posterior tibiæ slightly spinose: tegmina black, adorned with numerous little green marks ; reticulated part, ferruginous; wings brown, adorned with bluish-green spots, white at the tips and along the

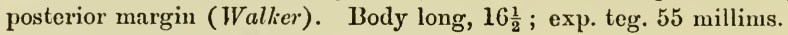

Reported from Malabar.

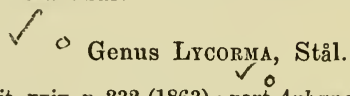

Stettin, Ent. Zeit. xxiv, p. 232 (1863) : part Aphana, Guérin.

Head somewhat protuberant, protuberance very short, reflexed: frons, distinctly upwards and at the base more narrowly, furnished with two parallel obtuse ridges, sometimes obliterated beneath the middle; vertex truncated at the base, last angles not produced : thorax finely earinate in the middle: first femora not amplified at the apex above: last tibiæ armed with 4-5 spines; unarmed at the base, above (Stål).

\section{$\checkmark$ o 35 . Lrcorma imperialis, White.}

$\checkmark 0$ Aphana imperialis, White, A. M. N. H. xvii, p. 330 (1846).

Aphena imperialis, Westwood, Cab. Or. Ent. p. 74, t. 36, f. 4. (18.18); Walker, List Hom. B. M. ii, p. 282 (1851).

$\checkmark$ O Aphæena placabilis, Walker, 1. c. Suppt. p. 46 (1858).

Lycorma imperialis, Stål, Ofvers. K. V.-A. Förh. p. 485 (1862); Stettin Ent. Zeit. xxiv, p. 232 (1863).

Tegmina olive-green, the basal portion with numerous black spots, most of which are traversed by green veins; the tip black, beautifnlly reticulated with olive-green : wings, at the base, purplish madder with 
11-13 large black spots, the purplish part reticulated with whitish; the end browuish-black; a bluish-green band-like mark aeross the midthe of the wing, not nearly reaehing the hind margin, the three nerves traversing it are hlick; tegmina and wings beneath almost samo as above: heal and thorax above greenish; prothorax finely, transversely striated, a line, down the middle, shining: abdomen black, margins yellow, segrments slightlly powdered with white, vulvar seales red: legs brown, tilia of hind legrs tridentate on the outside (White). Exp. teg.
61 millims.

Reported from Silhat: the Indian Museum possesses specimens from Sikkim. Red: metanotum black: abdomen with a red transverse line at the base; tip red beneath : tegmina with black spots along the costa and with some more or less interrupted and irregnlar black bands; more than one-third of the apieal part black with very numerons and regular black veins and veinlets : wings black, basal half red with several black spots; a white milllle band, not extending to the hind border ( $A$. placabilis, Walker). Body long $16 \frac{1}{2} ;$ teg. $54 \frac{1}{2}$ millims. This is the
reddish-brown variety.

\section{Lycorara punicea, Hope.}

'० Lystra punicea, IIopo Trans. Linn. Soc. xix, p. 133, t. 12. f. 5 (1813); Walker, List IIom. B. MI. ii, p. 286 (1851).

$\checkmark \cap$ Aphuna delectabilis, Walker, l. c. Snppt. p. 44 (1858).

Lycorma punicea, Stål, Stettin Ent. Zeit. xxiv, p. 232 (1863).

Reddish purple, head and thorax paler; basal half of tegmina tinted rosy and sprinkled with numerous black spots; apex hyaline fuseons-pmniceous with a pellueid mark in the middle of the dise : wings pmieeons at the base, marked by black spots, whitish in tho middlo and fuscons-lyyaline, at the apex (IIope). Long $12 \frac{1}{2}$; exp. teg. 48 millims.

Ferruginous brown, black beneath : antemwo bright red ; pronotum dull green witl some very minute, testaceous, brown-bordered spots : abdomen black: hind borders of the segments luteous on each side, beneath: legs black : tegmina black, whitish green with black spots for about one-third from the base, outline of the green part much excavated with some streaks same hue near it; veins green: wings bright red with black spots, apical part. blackish brown, divided from the red part by a bright greenish blue band which does not extend to the hind margin: ${ }^{\circ}$ (A. delectabilis, Walker). Body long, $12 \frac{1}{2} ;$ exp, teg. 42
millims.

Reported from N. China, Shanghai, India, Silhat. The Indian MIuseum possesses a mutilated specimen from the Dikrang valley, As- 
O 37. Lrcorma 10Le, Stål.

Lycorma iole, Stål, Stettin Ent. Zoit. xxir, p. 23 \& (1863).

13lackish: the lateral posterior bloteh on the vertex, thornx, lateral margins of scutellum, and the tegmina more or less purely green-oliraceous, the tegmina with 23-28 largish black spots, barely third apical part black, grecn-veined: wings coccineous with 8-10 black spots, blackfuscous behind the middle and there with a shortened loand, vireseent or crerulescent; anal valvules in $\&$ sanguineous (Slål). $\&$ long, 17 ; ехр. teg. 52 millims.

10

Reported from India : closely allied to $L$. delicatula, White, larger, cephalic process less prominulous, and the spots on the tegmina and wings larger.

$\checkmark$ ، 38 . Lrcorma detichtula, White.

$\checkmark \circ$ Aphana delicatula, White, $\Lambda$. M. N. II. xr, p. 37 (181.5).

- s A phurna delicntula, Wnlker, List. IIom. B. M. ii, p. $2 \$ 2$ (1.51).

- Aphn'na opernsa, Wnlker, 1. c. Snppt. p. 46 (1858).

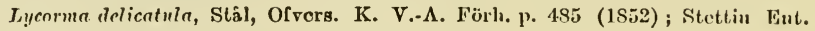
Zcit. xxiv, p. 232 (1863).

Tegmina very pale greenish brown, basal part with many black spots (at least twenty) of which six on the anterior margin: the end darker brown, beautifully reticulated with pale greenish brown: wings at the hase, vermillion red with largish black spots, irregnlar on either side (at lenst seven), tip widely black; a large acutely triangnlar sea-green mark on the fore-edge between the red and black parts: antemo orange : liead and thomx above of a pale brownish colonr with a sort of bloom over them: body and legs blackish brown with a slight bloom (1White). Exp. teg. 4.1 millims.

Reported from Nankin, Canton, China: very doubtfully from Sibságar (Assam). The cephalic process in this species is a little moro elevated than in L. imperialis, White, to which it otherwise bears a strong resemblance: the black spots on the wings and tegmina also are smaller, the tegmina are palely olivaceous or whitish fawn-colour: the median band on the wings varies, as in all the others of this group, from whitish to crerulescent or virescent (Stål).

\section{'o Genus Euphris, Stâl.}

Stettin Ent. Zeit. xxir, p. 232 (1863); part of $A$ phena, Gućrin.

Head furnished with a cephalic protuberanee, very slender, acnte, reflexed or erect; frons distinctly narrowed upwards, abruptly narrower at the hase furnished with 2-3 ridges, a little elevated, parallel : vertex 
very broadly sinuated at the base: thorax barely carinate in the midlle: first femora slightly annlified at the apex above; last tibio 4-spinuse; unarmed above at the base (Ślål).

\section{Numiria a urantia, Нope.}

O Aphana aurantia, IIope, Trans. Linn. Soc. xviii, p. 443, t. 31, f. 2 (1811).

Euphria aurantia, Stal, Stettin Ent. Zeit. xxiv, p. 232 (1863).

Entire body above orango; tegmina sprinkled with barely visiblo yellow spots, posteriorly spotted black; a few minute spots on the internal margin and a very narrow border on the posterior margin, black: head excavated above, margins elevated; frons produced abovo the pronotum in a small, tapering, recurved horn: abdomen, at tho base, covered with a white powdery substanco; body beneath concolorous, a little moro obscure (1Lope). Long 19 ; exp. teg. 63 millims.

Reported from Assam; tho Indian Museum possesses a specimon from Sikkim.

Fresh specimens have the tegmina green instead of orange, sprinkled with whitish powdery spots or patches, more distinct beneath: wings orange, body and abdomen orange yellow, in one specimen inclined to brown ; feet (except posterior femora) in some greenish, in others concolorons with the abdomen, recurved horn in some green, in others orange. Also the apices of the tegrmina are sometimes faded yellow more or less. $\Lambda$ long series should supply tho links. The Indian Museum has several specimens from Darjiling.

\section{r. $c$ 40. Euphria submaculata, Westiwood.}

i) Aphena submaculata, Westwood, Dnncan's Nat. Lib. i. p. 284 t. 24, f. 1 (1840); Walker, List IIom. B. MI. ii, p. 275 (1851).

A Aphana resima, Stål, Ofvers. K. V.-A., Förh. p. 190 (1855).

Euphria sulmaculata, Stàl, Stettiu Ent. Zoit. xxiv, p. 232) (1863).

Sordid yellow-testaccons; frons with a cephalic protuberance or horn, twice as long as the vertex, channelled above, recurved: lateral margins of thorax narrowly black: scutellum obsoletely tricarinate: tegmina rufous- testaceous above densely spotted whitish-mouldy, costal spots subglaucescent: wings nigro-fuscous, yellow-cinnamon beyond the middle, especially before the middle spotted whitish mouldy: abdomen above whitish-mouldy (L. resima, Stål). Body long 21 ; exp, teg. 71 millims.

Reported from India : the Indian Museum possesses specimens from Sikkim.

\section{Eupiria Lecirissima, Walker.}

Aphana lectissima, Walkor, List. Hom. B. M. Suppt. p. 45 (1858).

Grass-green : head with a short, acute, almost vertical horn; siles of the vertex carinate; frous and face flat, the latter with a slight ridge : 
abdomen above testaceous : tegmina livid, red beneath, except towards the apex, adorned with many green, white-dotted, spots; border green, adorned with dots of white tomentum along the eosta, and with black dots elsewhere, except towards the base of the inferior border whero the dots are luteous: wings crimson for more than half tho leugth from the base (Walker). Body long, 21 : exp. teg. 33 millims.

Reported from N. Indias the Indian Mruseum possesses a specimen from Sikkim. Closely allied to ${ }^{\circ} \mathrm{E}$. amabilis, Hope, from which it differs in the absence of the three fulvous spots on the pronotum and of the blackish lines on the mesonotum and posterior margins of the abdominal dorsal segments, and in the spots on the tegmina, which are small and circular, nowhere linear and transverse. Stal (Ofvers. K. V.- $\Lambda$. Förh. p. 486, 1862) unites the two species.

\section{4.2. Eupiria amabilis, Hope.}

$\checkmark$ \& Aphana amabilis, Hopo, Trans. Linn. Soc. xix, p. 132, t. 12, f. 1 (1815); Walker, List. IIom. B. M. ii, p. 274 (1851).

Euphria amabilis, Stål, Stottin Ent. Zeit. xxiv, p. 232 (1863).

Body above orange; head green, furnished with an erect, acute, slender horn : prothorax green, marked by three fulvous spots : tegmina cretaceous sprinkled with numerous oval spots ; wings coecineous, palely virescent at the apex : body beneath green; fect concolorous; pectus sprinkled over with a whitish down. The spots which abovo appear to be white and green intermixed are beneath entirely green (Hope). Long 25 : exp. teg. 69 millims.

Reported from Silhat.

\section{$\checkmark$ c) 43. Euphria aurora, Hope.}

Aphana aurora, Hope, Trans. Linn. Soc. xix, p. 133, t. 12, f. 2 (1815) : Walkor, List. Hom. B. MI. ii, p. 275 (1851).

Euphria aurora, Stål, Stettin Ent. Zeit. xxiv, p. 232 (1863).

Allied to ${ }^{\circ}$. aurantia, but smaller; almost the whole body orange : tegmina externally barely virescent, internally orange and sprinkled with very minute whitish spots : body beneath concolorous: wings with cretaceous spots; last tibiæ externally spinose (Hope). Body long, 19 ; exp. teg. 61 millims.

Reported from Sillat, Philippines.

\section{$\checkmark$ 44. Euphria (P) Walkeri, n. sp.}

$\checkmark 0$ Aphœna dives, var. (P), Walker, List. Hom. B. M. ii, p. 281 (1S51).

Body yellowish brown, red beneath : vertex slightly ridged and furrowed: frons rather prominent, furnished with a slender, black, linear furrowed horn which is inclined backward nearly to the posterior margin 
of the shichl : rostrum ferruginous, tip darker, extending nearly to tho tip of the alulomen : an exeavation partly inclosing the eye on each siclo lateral margins of pronotum and most of metanotum, black : ablomen a litle longer thun the thorax, nearly olliptical, red, with a black hand across each segment alovo: legs black, furrowod, femora red, posterior tihie spinoso: tegmina not mnch longor than tho wings, apox olstuse, pale dingy yellow with very numerous brown marks, retieulaterl part, yellowish-hrown: wings brown with many almost colourless spots which are partly contluont, posterior margin almost colourless, tip palo brown (Irullier). Boily long $14 \frac{1}{3}$; exp. teg. 42 millims.

Reported from lndia.

\section{$\checkmark \circ$ Genus Proronis, Stål.}

Stcttin lint. Zoit. xxiv, p. 233 (1863).

IIeal not protuberant but emitting from the base of the frons a very long, very slender, mobile, reflexed process [which in dried specimens is very easily detached]; frons a little narrower above the middle thau beneath the middle, aloruptly narrowed at the base, furnished with two olstuse, parallol rilges (often obliterated), lateral margins slightly simuate beneath the midlle; vertex truncated at tho baso : thorax hardly carinato in the midllo, first pair of femora distinetly amplified above at tho apex: last pair of tibia 4 -spinose, furnished abovo at the baso with is tulserelo (Stal).

0 45. Phoronis migro-maculata, Guérin.

Aphepna vigro-maculatu, Guérin, Icon. Règno An. t. 90, f. 6 (1830-34); Voy. Bélanger. Incl. ()rient. Kool. p. 457 (1834); Spinola, A. S. E. F. (1 sér.) viii, p. 243 (1839); Walker, List. 11 m. 13. MI. ii, p. 273 (1851).

6 P'ulgura (Alhena) nigro-maculatu, G. R. Gray, Griflith's ed. Au. King. Ins. ii, p. 260 t. 90 , f. 6 ; t. 138, f. 1 a-c. (1832).

$\checkmark \quad$ Aphana nigro-maculota, Westwood, Trang. Liun. Soc. xviii, p. 149 (18+1).

Phoronis nigro-maculata, Stål, Stettin Ent. Zoit. xxiv, p. 233 (1863).

Head and thorax brown; horn black, short, flexible; tegmina brown with some small seattered black spots, exterior margin with a broad black border: wings with basal half silvery grey, spotted with black; other half, black, with the interior margin brownish black; body silvery grey, with transverse narrow bands of black (Gray). Head subferruginous, brown ; frous with a cylindrical horn recurved backwards; thorax somewhat greenish brown : togmina obseurely blue, apex finely reticulated with black, punctured with black on the anterior margin with five dots obliquely arranged at the base: wings blue, spotted with black, posteriorly brown, black at the apex : abdomen black, streaked 
with white: horly below ant femoin ruldy: eoxa bown (chuírin). Long 20 ; broad 55 millius.

Reported from China, Cochin-China : tho Indian Muscum posscsses n specimen from the Andaman islands with tho cephalic process absent.

\section{$\checkmark$ 4 4. Phoronis padlinia, Signorot.}

$\checkmark$ () Aphena paulinin, Signoret, A. S. E. F. (4 sér.) ii, p. 123 ; t. 1, f. 6, (1862).

Brick-red witls the dorsum, femora, tips of tegmina, tip of the wings and sercral spots on them of a blackish-brown; on the anterior margin of the tegmina screral black spots and a slight filiform, recurved cephalic process. Head broader than long, vertex squarc, a little transrerse, with a transrerse ridge and a foven on cach side of the cyes: frons convex, willout a riclge on the anterior margin, a black filiform appendage, with a. longitudinal groove, reaching almost tho end of the mesonotum : rostrum of a redrlish-brown, reaching tho end of the alstomen, the third joint, tho lougest: pronotum almost fivo times hoader than long, posterior margin concave, anterior convex with a median cmargination which gives it a bilobed apperance, presenting on ench side, bencatl the cyes, a strong cmargination : lateral margins convex and black, a slight ridge on the dise : mesonotum weakly tricarinale, nut exhiliting towards its cxtremity two small brown dots. Tegmina with a broud apical band formed of a network of yellow veinlets on a brown ground ; on the anterior margin are numbers of black dots, the clavial rein near the fold of the tegmen with 3-5 black dots: wings transparent in the mildle, slightly bluish and exhibiting there nhont a dozen more or less regular brownish spots; tip brownish ; the border, also the folded part near the abdomen, slightly infuscato : abdomen red hencath, black aloore, with the end of the scgments and the lateral margins, red ; each segment, especially those of the extremity, covered with a thick farinose sulsatance : feet with the tibio red and the femorn black, the posterior with three sirong spines on the extcrnal side (Sign.) Body long, 16 ; cxp. teg. 50 millims.

Reported from Cochin-China; the Indian M[useum has a specimen (witl the filiform cephalic process wanting) from 'T'cnasscrim. Stâl unites [1,is with $P$. nigro-maculata, Guérin, but though structurally the same, the coloration of the tegmina leares no doubt as to specific identity.

\section{b' Genus Genenns, Slâl.}

Trans. Ent..Soc. (3 sér.) i, p. 682 (1863); IIen. $\Lambda$ fric. ir, p. 135 (1866).

Head broadish, narrower than the thorax, not protuberant; vertex transverse, antcrior margin straight, postcrior margin broally sinuate; frons subquadrate, somervhat amplified on both sides at the elypens, median area amplificd upwards, broadly subtruncale at the apex, prominulnus before the apical margin of tho vertex, not reflexed; clypens 
ecarinate: second joint of antennœ transverse, produced upwards from the insertion. Thorn unicarinate in the middle, roundly prodnced at the apex behind the vertex: scutellnm about half longer than the thorax. Tegmina barely amplified towards the apex, rounded at the apex, costal margin straight, longitudinal veins rarely furcate, small transver'so veins remotely seattered thronghout tho entire tegmina : wings romotely transversely veined behind the middle. Feet simple, last tibir 4-spinose with their base neither spinose nor tuberculated (Stål). Allicd to - Aphana.

\section{o 47. Gebenna Srlvia, Stål.}

Gebenna Sylvia, Stål, Trans. Ent. Soc. (3 sér.) i, p. 582 (1863).

Palely grey-flavescent; frons, vertex and dise of thorax and sentellum mintely irrorated black; thorax and seutellum on both sides sprinkled with small black spots: tegmina weakly rufeseent-ferruginous from the base beyond the middle, remotely sprinkled black, eostal limbus palely olivaceons-virescent; apical part vitreons, sprinkled and spotted fuseous ; wings vitreous, palely virescent towards the base, adorned with three irregular, large, subeonfluent, black-fuseous spots, before the middle : dorsum of abdomen, black; segments margined olivaceons at the apex; ablomen adorned with four longitudinal rows of irregular greyflaveseent spots; ventral segments on both sides, spotted black, interruptedly banded black at the base: feet with numerous black bands (Stål). P, long', 13 ; exp. teg. 39 millims.

Reported from India. Vertex almost thrice as broad as the transverse eye, margins somewliat elevated: frons remotely and finely rugulose, slightly narrowed upwards: thorax less distinctly rugulose : scutellum finely rngulose on the dise.

\section{v. Genus Polydictra, Guérin.} (1866).

Ieon. Riggno Anim. Texto Ins. p. 359 (1830-31); Stål, Hem. Afrio. iv. p. 135

Vertex about four times as broad as the eyes : entire tegmina densely or very densely reticulated : anterior tibiro sometimes somewhat dilated : frons obtusely romded at the base, amplified at the apex and distincly broader than the clypeus, tegmina thrice or more than thrice longer tlian broad (Stål).

\section{$\checkmark$ 4 48 . Polydictya basalis, Guérin.}

Polydictya basalis, Guérin, Icon. Règne Anim. Texte, Ins. p. 359 (1830-34); Walker, List. IIon. B. M. ii, p. 289 (1851); J. L. S. Zool. x, p. 98 (1867).

() Aphona uniformis, Walker, J. L. S. Zool. i, p. 141. (1857).

Eurylrachys basalis, IIIope, Trans. Linn. Soc. xix, p. 134, t. 12, f. 6 (1815); Stål, Ofvers. K. V.-A. Förh. p. 500 (1862). 
Fuscous yellow : head flavescent : thorax brunneous ; abdomen dull red; tegmina fuscous, retieulated yellow; wings at the base with a cxrulean incurved line forwards, posteriorly subroscous; remainder blackish (IIope). Body long, 21 ; exp. teg. 56 millims.

Reported from Sumatra, Sillat. There are at least two apparently undescribed species of this genus in the Indian Museum: one with a double incurved cærulean line at the base of the wings, abdomen vermillion with the dorsal segment more or less banded black, (body long, 16 : exp. teg. 46 millims), from the Andamans; and one with the base of the wings red and base of the tegmina above and below with a bluish tinge, (body long, 19 : exp. teg. 53 millims), from Sikkim: but a scries is desirable before describing them further.

\section{$\checkmark$ 49. Politictya (P) tricolor, Westwood.}

\section{$\checkmark$ Lystra tricolor, Westwood, Are. Ent. ii, p. 35, t. 37, f. 4. (1815).}

Polydictya tricolor, Walkor, List. Hom. B. MI. ii, p. 290 (1851).

Sanguineous, very glabrous; anterior lobe of pronotum and mesonotum anteriorly black, basal half of tegmina (the livid base itself excepted) stramineous, spotted black; apical half brunneous; costal spot stramineous : wings red, apical half fuscous : fect chestnut sanguincous

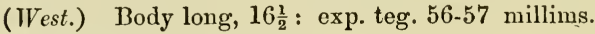

Reported from Assam.

\section{- Genus Ancrra, White.}

A. MI. N. II. $x \nabla$, p. $3 t(18.15)$.

Allied to Eurymela, Hoff.; but distinguisher from it by the shape of the head which has not the dilated gene, no stemmata, antenne close under the eyes : tegmina finely veined, with a notch on the postcrior margin and rounded at the apex, whence (in \&) proceeds a longish narrow appendage, widest at the end: legs much dilated and eompressed throughout: hind legs very long with four spines on the outer edge of the tibia : the end of the body covered with a waxy down-like secretion (White).

\section{$\checkmark$ 50. Ancyra appendiculata, White.}

Ancyra appendiculata, White, A. M. N. H. xv, p. 34 (1815); Westwood, Cab. Or. Ent. p. 74, t. 31, f. 5 (1848) ; Walker, List. Hom. B. M. ii, p. 395 (1851); Distant, J. A. S. xlviii (2), p. 38 (1879).

Rich deep brown: tegmina, above brown, spotted at base with white and with two widish powdery bands of white; beneath, mahogany red: wings deep brown almost black on the edge and between a redcoloured space : body beneath yellow : legs black : wings more powdery 
in the of than in the of (White). Long $9 \frac{1}{2}$; exp. teg. excl. appendage 25 millims.

Reported from Maulmain : the Indian Museum possesses a specimen from Teuasserin.

\section{$\checkmark$ o 5l. Ancyra mistrionica, Stål.}

Ancyra histrionica, Stål, Stettin Ent. Zoit. xxiv, p. 245 (1863).

Fuscous-ferrnginous: frons yellow-ferruginous adorned with five subclevated, narrow, black bands : tegmina obscurely ferruginous, basal part and obliquo band behind the middle, fuscescent, apical callus black, apical appendage fuscescent-ochraceous : abdomen flavescent (when alive sanguineons?), apex covered with a mouldy pubescence; feet blackish. Closely allied to preeeding; tegmina, especially behind the middle, broader, apical appendage shorter, fuscescent-ochraceous not blaek-fuscons, apieal callus smaller, wings broader and their apical process shorter (Stal). \&, long, 11; exp. teg. 26 millims.

Reported from Cambodia; the Indian Museum has a specimen from Pegu; but the desiecated body is only 8 millims long and the basal part and band behind the middle of the tegmina is lighter dull ferruginous, not fuscescent.

\section{Correction.}

C. maculicollis, Guérin, in J. A. S. LIII (II) p. 230, No. 76, is a synonym of Tibicen brunneus, Fabr., as follows :-

- Tibicen brunneus, Fabricius.

Tettigonia brunnea, Fabr., Ent. Syst. Suppt. p. 517 (1798); Syst. Rhyng. p. 43 (1803).

¿ Cicada brumnea, Germar, Thon's Arch. ii (2) p. 6 (1830); IValker, List. Hom. B. M. i, p. 230 (1851).

Cicada maculicollis, Gnérin, Voyag®e la Coquille, Zool. ii, p. 183 (1830): Walker, 1. c. Snppt. p. 28 (1858).

(: T. (Abricta) brunneus, Stål, Hem. Afric. iv, p. 26 (1866).

Ferruginous or testaceous, paler beneath: apex of the scutellum and two very large spots on the thorax, ferruginous-flavescent, the latter with two fuseous streaks: head, a small posterior median spot and a transverse impression on the thorax towards the sides, blackish or fuscescent-ferruginous; a spot on the lobes of the vertex, ferruginous: fonr triangnlar spots on the scutellum extended backwards from the base, fuscons; the median pair smaller, often obsolete; the lateral pair produced to a distanee backwards : tegmina and wings sordid vitreons, veins testaeeous-flavescent, fuscous towards the apex: head a little broader than the anterior part of the thorax: ocelli somewhat more 
distant from the eyes than from each other: thorax gradually a little narrowed from the apex backwards beyond the middle (Stail). $\delta, q$, long, 21-24; exp. teg. 60-73 millims.

Reported from Mauritius, Bengal,

In J. A. S. B. LIV (II) p. 23 Cosmopsaltria abrlulla, I)istant, is recorded as a synonym of $C$. spinosa, Fabr. (1. c. LIII (II), p. 227) : the following is Distant's description of C. abilulla.

8. Body above castaneous, more or less covered with greyish pubescence and pilosity: head with the vertex somewhat sparingly pilose and the area of the ocelli, a little infuscate: pronotum sparingly pubescent with a central $\times$-shaped space denoted by strix, followed by two oblique strie, the onter one submarginal and slightly curved, lateral and posterior margins densely pubescent: mesonotum with two faintly indicated obovate spots on the anterior margin, sparingly pubescent, tho lateral margins and the region of the cruciform basal olevation much more densely pubescent. Abdomen sparingly pubescent but much moro densely so on the dise and the lateral margins: body bencath ochraceous : first and intermediato femora with the bases and apices fuscons, the central portion palo ochraceous: first tibio castancous and tarsi piccous; intermediato tibiro pale castaneous, with tho base narrowly and the apex broadly piceons : last pair of legs pale castaneous, apices of femora, bases and apices of tibix, dark castaneons. Tegmina and wings pale hyaline; the former with the costal membrano and basal area. castaneous, claval area, piceous, transverse veins at bases of $2,3,5$ apical arens infuseato and a submarginal series of small fuscons spots at apices of longitudinal veins : wings with anterior claval margin and a curved basal streak dark castaneous. The face is very swollen and couvex beueath, longitudinally furrowed and transversely striated: tho rostrum extends just beyoud tho base of the femora: the operenla reach tho base of the fourth abdominal segment; the onter margins are deeply narrowed and concave near the base and then become slightly convex to the apex which is broad and rounded, theso opercula are very wide apart at the base and are confined to the lateral side of the undor surface of the abdomen (Dist.). 
Notes on Indian Rhynchota. No. 5.-By E. T. Atrinson, B. A., President.

[Received August 11th ;-lload Novomber 4th, 1885.]

O Subfamily Euryracirdina, Stål.

Eurybrachydida, Stâl, Iem. Afric. iv, p. 129 (1866) : Eurybrachydina, Ofvorø. K. V.-A. Förh. p. 753 (1870).

Anal area of wings vory rarely reticulate, when so, clypeus convex withont lateral rilges: last tibix without a mobile spur at the apex. Frons broad, transverse or almost equally long and broad, amplified on both sides in a distinct angle : anterior feet compressed, more or less . dilated : anal area of wings sometimes reticulated (Stål).

Stål clistributes the gencra included in this subfamily into two great groups :-

(1) those in which the eyes beneath are spinose.

(2) those in which the eyes beneath are unarmed.

a. Genera furnished with eyes spinose beneath.

I. Wings less ample, not or scarcely broader than the tegmina: head very broad; antennø briefly cylindrical; eyes bencath very distinctly spinose; clavus very broad at the apex.

A. Head very slightly prominulous before the eyes; genæ narrower; frous scarcely or only a little broader than the thorax; last pair of tibiæ 5-spinose :-Eurybrachys, Guérin.

B. Head more prominulous before the eyes; genæ broader; frons distinctly broader than the thorax; vertex scarcely or only a little shorter than the thorax; last pair of tibix 6-spinose :-Messena, Stål.

II. Wings ample, broader than the tegmina.

A. Vertex distinctly sinuate at the base: lateral angles of frons much produced; antennæ briefly cylindrical; clavus broad at the apex, two longitudinal veins separated through their whole length: median longitudinal area of wings dilated, furnished almost entirely with transverse veins ; last pair of tibiæ 6-spinose:-Thessitus, Walker.

B. Vertex very slightly sinuate at the base oy truncated : lateral angles of frons somewhat straight, less produced than in Thessitus, Walker : clavus narrowly open at the apex, the longitudinal veins united nearly in the midille; wings without a dilated area.

a. Head hardly broader than the thorax, vertex truncated at the base; second joint of the antennæ very briefly subcylindrical; last pair of tibia 5-spinose :-Loxocephala, Schaum. 0

$b$. Head narrower than the thorax, vertex subsinuate at the base; second joint of the antennæ subglobose: last pair of tibiw normally 4-spinose :-Nesis, Stăl. $0 \mathrm{~V}$ 
b. Genera furnished with eyes unarmed beneath and clavus closed at the apex, somewhat acute.

1 (2). Last pair of tibiæ nsually 6 -spinose; scutellum longer by lalf than the thorax : antenno short, second joint subglobose :-Frutis, o Stål : $\cup^{\complement}$ zype $F \cdot$ pulchra, Gray.c

2 (1). Last pair of tibiæ normally 3 -spinose.

3 (8). Frons transverse, angulated on both sides.

4 (7). Thorax and scutellum together distinctly shorter than the breadtl.

$v^{5}(5)$. Antennæ short, not extending beyond the eyes:-Olonia, Stål :-O apicalis, Walker, from Australia.

6 (5). Antenno cylindrical, longer, extending beyond the eyes, tegmina narrowel towards the apex: - ODardus, Stål:-D. bufo, Walker, from Anstralia.

7 (4). Thorax and scutellum together equally long and brond: antenno short :- Platybrachys, Stal :--P. leucostigme, Walker, from A ustralia.

8 (3). Frons scarcely broader than long, roundly-amplified on both sides; lateral angles of vertex ascending: antennæ subcylindrical, long, extending much beyond the eyes $;$ tegmina narrowed towards the apex (wings absent?) : $:-$ Gedrosia, Stål :-G. varia, Walker, from Australia.

These do not include the whole of the genera falling under this subfamily, but are enough for our purposes.

\section{$\checkmark \circlearrowleft$ Genus Eurybrachys, Guérin, Stål.}

Gnérin, Voy. Bélangor Ind. Orient. p. 475 (1834); Burm., Handb. Ent. ii (i) p. 149 (1835); Spinola, A. S. E. F. (1 sér.) viii, p. 367 (1839); Walker, List. Hom. B. M. ii, p. 381 (1851) : Stål, Stettin Ent. Zeit. xxiv, p. 245 (1863).

Guérin's diagnosis of the genus is as follows:- 'Antennæ rather long, extending a little beyond the sides of the frons, the first joint short, the second long, granulate, cylindrical, a little rounded at the tip, at least thrice longer than broad, with the filamentous portion of the antennw inserted at the extremity and very near the eyes: ocelli apparently absent: frons transverse, the anterior portion in form of a transverse lozenge, flat, ecarinate: labrum small, triangular: rostrum short, reaching barely the intermediate coxw : thorax transverse, with the anterior lobe a little narrower : tegmina a little longer than the abdomen, dilated at their base, and a little contracted at the extremity : abdomen as high as broad: feet rather long, spinose; anterior and intermediate tibir flattened and dilated. 
1. Eurybrachys venusta, Stål.

Eurybrachys venusta, Stål, Stettin Ent. Zeit. xxiv, p. 245 (1863).

q. Sanguineous; head, thorax anteriorly and barely basal half of tegmina olivaceous-green; the basal half of the tegmina spotted fuscous, and the base itself, sangnineous; corium behind the middle and commissural limbus of clavus, greyish, veined subolivaceous; wings whitish, subsanguineons at the base and veined sanguineous : abdomen sordid stramineous (sanguineous when alive?), beneath banded black. In stature like $E$. tomentosa, Fabr., differs in having the tegmina more distinctly and densely veined behind the middle. Tegmina twice longer than broad, subeoriaceous before the middle, opaque (Stål). Long, 10; exp. teg., 25 millims.

Reported from Nilgiris.

2. Eurybrachys tomentosa, Fabricius.

10 Cicada tomentosa, Fabricins, Syst. Ent. ii, p. 683 (1775); Spec. Ins. ii, p. $32 \cdot 4$ (1781); Mant. Ins. ii, p. 269 (1787); Ent. Syst. iv, p. 30 (179-1).

o Lystra tomentosa, Fabricius, Syst. Rhyng. p. 60 (1803); Germar in Thon's Archiv. ii, fase. 2, p. 55 (1830).

Eurybrachys tomentosa, Burm., Handb. Ent. ii (i) p. 150 (1835); Am. \& Serv., IIist. Nat. Ins. If́n. p. 517 (1813); Walker, List. Iom. B. M. ii, p. 381 (1851); Stål, Hem. Fabr. ii, p. 100 (1869).

\$. Green-olivaceous; tegmina olivaceous-green, with small scattered spots and two oblique bands, flavescent, apical part flavescentgreyish; small apical spots arranged in two transverse rows and a larger spot at the commissure, black, shining: wings whitish, a band abbreviated inwards behind the middle and a band continued through, placed near the apex, black : pectus and feet sanguineous, tibiæ and last pair of tarsi infuscate; abdomen croceous, disc of venter, black. Closely allied t $6^{\circ} \mathrm{E}$. spinosa, Fabr., differs in the head a little broader, almost broader than the thorax, tegmina more ample, much spotted in rows at the apex, wings adorned with a band running through them near the apex, not by a small spot, and the first pair of tibiæ above a little more dilated (Stål). Exp. teg., 24 ; broad, 4 millims.

Reported from Sumatra, India? E. fraterma, Stål [Ofvers. K. V.-A. Förlı. p. 450 (1858)], from Ceylon is hardly distinguishable from E. tomentosa, Fabr.

\footnotetext{
$\checkmark$ 3. Euribrachys bimaculata, Fabricins.

ó Lystra 2-maculata, Fabricins, Syst. Rhyng. p. 60 (1803).

$\checkmark \quad O$ Lystra bimaculata, Germar, in Thon's Arch. ii, fasc. 2, p. 55, (1830.) Eurybrachys bimaculata, Stål, Hem. Fabr. ii, p. 100 (1869).
} 
§. Weakìy greyish-olivaceous; tegmina concolorous, pellucid, re motely and very obsoletely sprinkled fuscous; a spot behind the ape: of the clavus and minute apical spots arranged in two transverse rows black, shining: wings very pale olivaceous-greyish hyaline,.colourles towards the apex and adorned with two black bauds, the one short reach ing the exterior margin, the other running through the wing; interio limbus slightly infuseate before the middle : feet weakly, sordid san guineous, sprinkled fuscons; tibiæ and last pair of tarsi, black : vente: black, margined flaveseent. Very closely allied to $0^{\circ}$ E. tomentosa, Fabr. coloration excepted, differs hardly except in the tegmina being a little narrower (Stål). Long, 6 ; exp. teg., 20 ; broad, $3 \frac{1}{2}$ millims.

Reported from Tranquebar.

\section{$\checkmark \quad 4$. Euryracirs spinoss, Fabricins.}

○ Cicada spinosa, Fabr., Ent. Syst. Suppt. p. 520 (1798); Cocquebert, Ill. ii, p. 45 t. 9 , f. $4(1790)$.

$\checkmark$ o Lystra spinosa, Fabr., Syst. Rhyng., p. 58 (1803).

Eurybrachys spinosa, Burm., Handb. Ent. ii, (i), p. 150 (1835); Spinola, A. S E. F. (1 sér.) viii, p. 369 (1839).

Frons large, blunt, yellow : eyes ferruginons, prominulons, furnished with a small acute, prominent, spine : head and thorax obscure: teg. mina deflexed, green, with three whitish oblique bands: feet san-

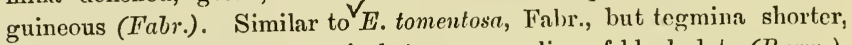
broader and without an apical transverse line cf black dots (Burm.). Long, $8 \frac{1}{2}$ millims.

Reported from India, Mauritius.

\section{$\checkmark \circ 5$. Eurybrachys hepeleetiert, Guérin.}

Eurybrachys lepelletieri, Guérin, Voy. Bélanger Ind-Orient. p. 476 (1834); Spinola, A. S. E. F. (1 sér.) viii, p. 369 (1839); Walker, List Hom. B. M. ii, p. 381 (1851).

§. Rufous : head transverse, broad, with the anterior part of the frons flat, of a golden yellow : antennæ rufous : eyes whitish, prominulous, with a small acute prominent spine: thorax trapeziform of a somewhat pale yellow ; tegmina of the same colour with a broad oblique rosy band, pointed towards the side, losing itself in the yellow in front, near the end another less marked band, a little reddish : wings white: body beneath and feet rosy red: abdomen yellowish (Guérin). Body long, 7 ; exp. teg., 19 millims. $\quad V_{0}$

Reported from Bengal : resembles $E$. spinosa, Fabr., in form and size, but differs in the coloration of the tegmina. 


\section{Eurtbrachys ponctifera, Walker.}

Eurybrachys punctifera, Walker, List Hom. B. M. ii, p. 383 (1851) ; Distant, J. A. S. B. xlviii, (2), p. 38 (1879).

$\delta$. Body fawn-colour, irregularly dotted with brown and black; liead nearly as broad as the thorax; vertex very slightly arched, much broader than twice its length; frons stramineous with small ferruginous marks, transversely angular towards the clypeus where it is sinuate; its breadth about twice its length : clypeus lanceolate, ferruginous, at the base stramineous: rostrum tawny, reaching a little beyond the middle coxa : fore-chest rounded in front, straight behind, not longer than the vertex, its breadth about four times its length : middle-chest longer than the fore-chest indistinctly 5-carinate: scutellum small, triangular, posteriorly acute : pectus pale stramineous : abdomen obconical, a littlo shorter than the thorax, banded with black towards the tip; anal appendages black : legs pale stramineous, mottled with black, especially on the fore legs : femora tinged with very pale green, with a few brown dots; only the tips of the fore-femora marked with black; hind tibiø 6 -spinose; tips of spines, black : tegmina fawn-colour, colourless towards the apex, adorned with black dots which are larger, more numerous, and more distinct towards the tips; veins tawny: wings almost colourless, each with a large black spot near the tip and a smaller one on the lind border at three-fourths its length; veins very pale green (Wullier). Body long, $10 \frac{1}{2}$; teg., $37 \frac{1}{2}$ millims.

Reported from Madras; the Indian Museum has a specimen from Tenasserim.

\section{$\checkmark$ 7. Eurybracirys (?) RUdricincta, Walker.}

Eurybrachys rubricincta, Walker, Ins. Saund. Hom. p. 46 (1858).

Testaceous : vertex transverse, short, slightly arched, with a brown dot on each side ; frons flat, smooth, transverse, dilated and angular on each side; face small: thorax slightly marked brown; pronotum slightly rounded in front with a slight median ridge ; mesonotum slightly tricarinate ; metanotum bright crimson : legs bright red, anterior legs much dilated : tegmina pale luteous, whitish at the tips with three spotted green batuls; some black marks on the veins, three black dots near the anterior angle and two black submarginal points: wings snowwhite with two black spots in front, the second almost apical. The abdomen in $\delta$ is furnished with foliaceous appendages; in $\$$, towards the tip, with a bundle of snow-white filaments (Wallier). Body long, $7 \frac{1}{4}$; teg., li $\frac{1}{2}$ millims.

lieported from N. India. 


\section{Eurtaracitys (?) rubrescens, Walker.}

Eurybrachys rubrescens, Walker, Trans. Linn. Soc. Zool. i, p. 88 (1856).

Testaceous: head, vertex, and thorax with reddish marks: frons greenisl testaceous : legs rosy red : tegmina pubescent, slightly tuberculated, with a black shining dot near the tip of the costa and at three-quarters of the length of the hind border, purplish red, and with black dots towards the base, tawny towards the tips, with a dingy hyaline median band and the borders chiefly of the same colour : wings milky white with

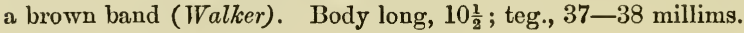

Reported from Mount Ophir, Singapore.

9. Eurybachys subfasciata, Walker.

Eurybrachys subfasciata, Walker, List Hom. B. M. ii, p. 391 (1851).

$\checkmark$ ○ Issus apicalis, Walker, 1. c. p. 368 (1851).

đ, + . Body short, broad, testaceous, sprinkled with a darker colonr : head as broad as the thorax : vertex very slightly arched with an indistinct ridge along the border, six times broader than long; frons short, flat, forming an acute angle on each side, not sinuate whore it joins the clypeus but forming an obtuse inward angle on each side near which it has two slight oblique furrows; more than twice broader than long: clypeus triangular, slightly rounded : rostrum ferruginous : eyes spinose : fore-chest very slightly rounded anteriorly, straight behind, a little longer than the frons : middle-chest longer than the fore-chest, subtriangular, its linder sides sinuate: pectus and metanotum red: abdomen obconical as long as the thorax : fore :nd middle legs red, very broad; hind legs slender, dark red, hind femora mostly pale yellow, hind tibiæ 4 -spinose, tips of spines, black : tegmina pale ferruginous, partly tawny, adorned at the tips with a few black spots of various size and varying in each specimen ; veins ferruginous : wings almost colourless or slightly tinged with brown, blackish with a white band towards the tips; veins

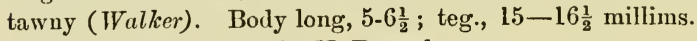

Reported from India, N. Bengal.

$$
\text { J Genus Messena, Stål. }
$$

Stettin Ent. Zeit. xxii, p. 246 (I863) : see p. 10.

\section{Vo 10. Messena pulverosa, Hope.}

$\checkmark$ Eurybrachys pulverosa, Hope, Trans. Linn. Soc. xix, p. 134, t. 12, f. $7 a, b$, (1845); Walker, List. Hom. B. M. ii, p. 382 (1851).

Messena pulverosa, Stå, Rio. Jan. Hem. ii, p. 67 (1862); Stettin Ent. Zoit. xxiv, p. 246 (1863). 
Shining whitish: head and thorax yellow, abdomen concolorous, having the end clothed with a white cottony substance: basal half of tegmina vireseent, apices fuscous-hyaline, sparingly spotted: wings whitish, with an irregular black spot at the anterior margin and other minute spots of the same colour placed posteriorly : first and intermediate pairs of feet of a red-lead colour, last $\mathrm{r}$ air fuscous (Hope). Body long, $14 \frac{1}{2}$; exp. teg., 55 millims.

Reported from Silhat : the Indian Museum has a specimen, locality unknown.

\section{Messena nebulosa, Stål.}

Messena nebulosa, Stål, Stettin Ent. Zeit. xxiv, p. 246 (1863).

9. Pale fawn-colour; tegmina sordid whitish, veined fawn-colour : towards the base fawn-colour or (especially beneath) weakly violaceousferruginous, belind the middle clouded and sprinkled pale-fuscescent; adorned near the apex in the middle of the apical part with a spot and at the conmissural margin, some distance behind the middle, with two spots (the posterior minute) or with one spot, black; sometimos sparingly sprinkled fuscons before the middle: wings whitisl, obsoletely banded with fusceseent hehind the middle, near the apex with some small black-fuscous spots which are sometimes wanting: abdomen (when alive?) sanguineous ; apex of the anterior femora and the first pair of tibio sprinkled fuseous, entire anterior tarsi and the last pair behind the middle, black-fuscons. Closely allied to $M I$. pulverosa, Hope, tegmina and wings narrower, the former are not amplified towards the apex and are $2 \frac{1}{2}$ times longer than the breadth (Stål). Long, 15; exp. teg., 47-50 millims.

Reported from Cambodia, Malacea and Perak (?).

\section{$\checkmark$ Genus Tressitus, Walker.}

Thessitus/Walker, Journ. Ent. i, p. 307 (1862); Stål, Ofvers, K. V.-A. Förh. p. 753 (1870): Thessitu, Stål, Stettin Ent. Zeit. xxii, pp. 216-247, (1863) : sce p. 10.

Sec. A. Vertex shorter than breadth by about one-half, deeply sinuate at the base, truncated at the apex, lateral margins obtusely elevated in the midlle; frons near the base furnished with a transverse, arched, distinct rilge, lateral angles much produced, rounded at the apex, lateral margins above and beneath those angles slightly sinuate; infraocular spines short, scureely visible from above: wings slightly narrowed towards the apex, apex broadly rounded. To this section belong' $T$. insignis, Westwood, ahd ${ }^{\mathrm{o}} T$. mortuifolia, Walker.

Scc. B. Vertex less deeply sinuate at the base, apex broadly rounded; frons furuished near the base with a straight obsolete ridge, 
parallel to the hasal margin, lateral angles rounded at the apex, lateral margins above those angles slightly sinuate, beneath them straight; infraocular spines somewhat largish, very prominent; wings more narrowed towards the apex than in section A. The ${ }^{\circ} T$. nigro-notata, Stả, belongs to this seetion.

\section{12. Thessitus insignis, Westwood.}

$\checkmark$ O Eurybrachys insignis, Westwood, A. M. N. II. ix, p. 119 (1842); Hopo, Trans. Linn. Soc. xix, p. 134, t. 12, f. 9 (1845); Walker, List. Iom. B. M. ii, p. 382 (1851); J. Linn. Soc. Zool. i, p. 155 (1857); 1. c. x, p. 133 (1867).

$\checkmark 0$ Eurybrachys multicolor, Walker, J. Linn. Soc. Zool. i, p. 88 (1856).

Thessita insignis, Stål, Stettin Ent. Zeit. xxiv, p. 2.7 (1863).

Thessitus insignis, Stảl, Ofvers. K. V.-A. Förh. p. 753 (1870).

Shining white: head and thorax yellow, sides of abdomen sanguineons : tegmina flavescent, sprinkled with various minute black spots : wings whitish, with an irregular black spot at the anterior margin and other minute spots of the same colour posteriorly : anterior feet fuscousyellow, posterior green, spines on tibix, blackish (Hope). Body long, $14 \frac{1}{2}$; exp. teg., 54 millims.

Reported from Malabar ; Philippines; Sumatra.

\section{$\checkmark \circ$ 13. Thessitus mortuifolia, Walker.}

Thessitus mortuifolia; Walker, Journ. Ent. i, p. 307, t. 15, f. 4 (1862).

Thessita mortuifolia, Stål, Stettin Ent. Zeit. xxiv, p. 247 (1863).

§. Fawn colour, tibir verging into olivaceous, first pair sprinkled fuscous: tegmina pellucid-greyish, veined fuscous and subolivaceous, marked with black spots and small black transverse lines at the margins; entire clavus and oblique basal part of corium olivaceous-virescent, corium alorned behind the virescent part with a very oblique sanguineous patch which does not reach the costal margin : wings whitish, furnished near the apex with 5-6 black spots, two larger and sometimes confluent. In stature very similar to $T$. insignis, Westwood; tegmina more than twice longer than broad, not amplified towards the apex, the apex obliquely rounded, costal margin slightly sinuate in the middle (Stål). Long, 14; exp. teg., 50 millims.

Reported from Cambodia: the Indian Museum has a specimen from Perak.

\section{$\checkmark$ O 14. Thessitusinigro-notatus, Stål.}

Thessita nigro-notata, Stâl, Stetting Ent. Zeit. xxiv, p. 217 (1863).

§. Fawn-colour : basal spotion clypeus, band on frons placed a little beneath the middle, abbreviated and interrupted in the middle, a band a little above the middle running: between the lateral angles and twice 
broadly interrupted, and small confluent spots placed at the basal margin and above the subbasal ridge, two spots on the genæ (one basal, the other apieal), five spots on tho vertex, antenno, two anterior and one lateral spot on the thorax, four small subbasal spots on the seutellum, apical spots on the first pair of femora and spots on the anterior tibie, black: tegmina towards the base more obseure, sparingly sprinkled blick and alorned with a sanguineous line near the costal margin before the middle; costal margin behind the middle and the apieal margin marked with small black spots : wings weakly fuscescent, veined obsoletely violaceous, apieal part sordid whitish, marked by a large spot (sometimes divided into two) and several minnte marginal spots, black-fuscous : last pair of tibie infuscate. Vertex more than twice broader than long: tegmina slightly amplified towards the apex, obtuscly obliquely rounded th the alpex : tibie 5-6 spinose ('stål). Long, 11 ; exp. teg., 32 millims.

Reported from Malacea, Tenasserim.

\section{$\checkmark$ Genus Loxocephata, Schaum.}

Ersel \& Gruber, Allg. Eney. Wissen \& Kunste, art. Fulgorida, sec. 51, p. 71 (1850) : see p. 10.

$\checkmark$ 15. Loxocepiala rruginosa, Hope.

O Lystra ceruyinosa, Hope, Trans. Linn. Soc. xviii, p. 443, t. 31, f. 1 (18+1).

$\checkmark$ O Eurybrachys cruyinosa, Walker, List Hom. B. MI. ii, p. 382 (1851).

Loxocephala eruginosa, Schaum, Allg. Enc. Wissen. \& Kunste sec. 5I, p. 71 (1850).

Boly above and head green; face flat, anterior margin acutely curved, frontal ridge between the eyes parallel with the anterior margin : tegmina sordid fulvescent varied with green and black; maryins externally dull black; basal half irrorated; apical half with a liuge round spot before the apex and the apex, black : wings powdered white :

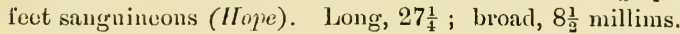

Reported from silhat. In a specimen in the Indian Musem from Sikkim the dull black margin to the apex is wanting or obsolete.

\section{- 16 . Loxocephala decora, Walker.}

$\checkmark{ }^{0}$ Eurybrachys decora, Walker, List Hom. B. M. ii, p. 382 (1851).

8 . Body green : head nearly as broäd as the thorax; vertex with a rim which is black in front and behind, slightly rounded anteriorly, very slightly sinnate posteriorly, abont three times broader than long; frons large, sentcheon-shaped, much broader than long, surrounded by a slight rim; clypeus small: rostrum tawny: pronotum hardly longer than the vertex, nearly straight behind, slightly rounded on fore-border along 
which there is a black land; thrice broader than long: mesonotum slıort, hardly longer than the pronotum, nearly triangular, with a black interrupted band in front: abdomen obconical, much longer than the thorax: legs red; fore legs rather broad and flat, fore tibire striped black, feet partly black : tegmina green with an oblique black band at the base, black along the tips, near which there is anotlier oblique black band in the disc, two white dots in the micldle, one near the fo:e borter, the second near the hind border and nearer the tip than the first; veins green: wings white, green towards the tips which are black; an oblique black spot on the fore-border near the tip ; veins pale yellow (Iralker). Body long, $10 \frac{1}{2}$; wings long, $29 \frac{1}{2}$ millims.

Reported from Assam : the Indian Museum possesses a specimon from Sikkim.

\section{VO Genus Nesis, Stål.}

Rio Jan. Hem. ii, p. 67 (1862) : see p. 10.

o 17. Nesis tricolor, Walker.

$\checkmark$ o Eurybrachys tricolor, Walker, List Hom. B. M. ii, p. 384 (1851).

Nesis tricolor, Stål, R. J. Hem. ii, p. 67 (1862) ; Stettin Ent. Zeit. xxiv, p. 248 (1863).

\$. Sanguineous; head weakly olivaceous, frons margined fuscous at the base ; tegmina blackish, weaker at the apex, variegated with confluent sordid stramineous-powdered spots; wings whitish. Differs from

$\checkmark \circ N$. sanguinipes, Stål, in not having the tegmina distinctly narrowed towards the apex. Vertex a little longer in the midclle than at the eyes, anteriorly broadly rounded: frons flat, aciculate : thorax bi-impressed in the middle: sentellum unicarinate : tegmina scareely narrowed towards the apex, costal and commissural margins subparallel, obliquely broadly rounded at the apex, transverse veinlets rare, fiue (Stål). Long, 9 exp. teg., 28 millims.

Reported from India.

\section{$\checkmark$ o 18. Nesis (?) SANGUinipes, Stål.}

VO Aphæna sanguinipes, Stål, Ofvers. K. V.-A Förh. xi, p. 245 (1854).

Head, sordid yellow-testaceous; thorax and scutellum obscurely rufous-testaceous : tegmina black-fuscous wilh two indistinet bands and several posterior spots yellow farinose; beneath with feet sanguineuus (Stål). Long, 8 ; broad, 4 millims.

Reported from India.

12 


\section{Genus Frotis, Stål.}

Ofvers. K. V.-A. FOrh. p. 488 (1862) : see p. 11.

19. Frutis pulchra, Gray.

${ }^{C}$ Lystra pulchra, Gray, Griffith's ed. An. King. Ins. ii, p. 260, t. 90, f. 5 (1832).

U Aphena pulchra, Walker, List Hom. B. M. ii, p. 278 (1851).

I Aphena veris-amor, Walker, J. Linn. Soc. Zool. i, p. 1.63 (1857).

Frutis pulchra, Stål, Ofvers. K. V.-A. Förh. p. 488, 500 (1862).

$\delta$. Greenish-brown with the abdomen bright red, the tip clothed with a whitish cottony substance : tegmina green at the base, spotted with white opaque colour, with a transverse arehed band of fulvous yellow; tip pale yellowish-brown : wings covered with a white rosy matter with brown spots near the base and pale yellowish-brown at the apex : veins delicate (Gray). Black, face and legs ferruginous: abdomen red: tegmina narrow, intensely grass-green, with the costa, a basal spot, a few dots on the disc and an exterior curved transverse line, yellow; tips tawny: underside with various marks of white tomentum which also appear on the eosta above, at the base: wings snow-white with tawny tips $V$ (A. veris-amor, Walker). Body long, 23; exp. teg., 55 millims.

Reported from Borneo, India : the type of the genus, see Stål.

20. Species of uncertain position.

Eurybrachis reversa, Hope, Trans. Ent. Soc. xix, p. 134, t. 12, f. 8 (1845); Eury. brachys id., Walker, List Hom. B. M. ii, p. 382 (1851).

Fuscous-yellow, head and thorax concolorous, abdomen whitish in the midlle, adorned posteriorly with a yellow cottony substance; apex shining white: tegmina fuseous-yellow, tinted subsanguineous at the base; a round white spot at anterior margin, a second smaller almost on the middle of the dise and other very minute spots sprinkled about: basal half of wings whitish, apex irregularly irrorated fuscous : four anterior feet yellow-fuscous; tibiæ more obscure; last femora

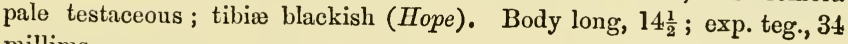
millims.

Reported from Sillat.

${ }^{\circ}$ Subfam. Dictyopharina, Stål.

Ofvers. K. V.-A. Förh. p. $7+1$ (1870) : Dictyopharida, Stål, Hem. Afric. iv, p. 129, 149 (1866) : Pseudopharides pt., Am. \& Serv., Hist. Nat. Ins. Hém. p. 502 $(1843):^{\circ}$ Dyctiophoroides pt., Spinola, A. S. E. F. (1 sér.) viii, p. 283 (1839).

Last tibix withont a molile spur at the apex : sides of frons not angulated; fect very often simple; anal area of wings never retieulate. 
Clavus very rarcly granulate, acuminate at apex, rarcly somewhat obtusish, distinctly closed, two veins distant or very distant from the apex, sometimes, however, bchind the middle of the clavus united in one; costa very rarely dilated : tegmina sometimes abbreviated or connate with clavus and corium. Claval vein not reaching the apex, united with the commissural margin near the apex: tegmina comnte with clavus and corium, the lateral margins of the clypeus always carinate or acuminate: frons without an apical ocellus (Stål).

\section{$\checkmark \circ$ Genus Dichoptera, Spinola.}

A. S. E. F. (1 sér.) viii, p. 286 (1839); Stål, Irem. Afric. iv, p. 149 (1866).

Tegmina not or barcly abbreviated, reaching at least the apex of the aldomen, very often extending beyond it: elivns distiuct, furnished with one transverse vein between the interior vein and the claval suture : heal narrower than the thorax: costa a little dilated, intramarginal : tegmina furnished with very numerous transverse veins towards the apex; feet longish : last pair of tibiæ multispinose, first pair longer than the femora (Stål).

\section{Dichoptera hyalinata, Fabricius.}

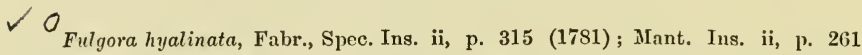
(1787) ; Olivier, Enc. Méth. vi, p. 572 (1791) : Fabr., Ent. Syst. iv, p. 5 (1794); Syst. lihyng. p. 4 (1803); Donovan, Ins. India, t. 7, f. 3 (1800).

$\checkmark$ Fulyora hyalina, Gmelin, ed. Syst. Nat. i (4), p. 2091 (1782).

$\checkmark$ OFlata hyalinata, Germar, Mag. Ent. iii, p. 190 (1818); Thon's Archiv. ii, (fasc. 2', p. 47 (1830).

$\checkmark$ O Dyctiophora hyalinata, Germar, Silb. Rev. Ent. i, p. 175 (1831).

$\checkmark$ O Pseudophana hyalinata, Burm., Handb. Ent. ii, (i), p, 160 (1835); Westwood, Trans. Limn. Soc. xriii, p. 150 (1841).

Dichoptera hyalinata, Spinola, A. S. E. F. (1 sér.) viii, p. 289, t. 13, f. 3 (1839); A n. \& Serv., Hist. Nat. Ins. Hém. p. 504 (1843); Walker, List Hom. B. M. ii, p. 303 (1851).

Frons producerl, short, conical, above inequal, beneath furrowed, pallid, with black dots and streaks : eyes large, globose, white : thorax pallid, irrorated black: scutellum more obscure: tegmina lyaline, veins punctured white and black and with a black streak in the middle : wings

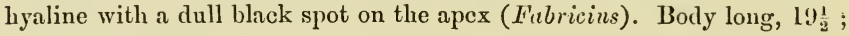
exp. teg., 50 millims.

Reported from Bengal: the Indian Museum possesses specimens from Bangalore, Calcutta, India. 
Genus Metaurus, Stål.

IIem. Aftic. ir, p. 151 (1866).

Head not or lut very slightly callons behind the eyes, this callons part seen frem the side forming a narrow margin behind the eyes, the cephalic process short and slender; vertex, the dise of the thoinx, and sentelhm lying in the same plane; frons and clypons long, the former triearinate, the litter unicurinale in tho middle; second joint of tho antemno short, sulghlolose; rostrnm extenling heyond the apex of the last coxø : thorax carinate in tho midlle : apieal two-thirds of the tegmina very densely reticulated, costa vory slightly dilated; the two claval veins united hehind the midlle : feet long, slender; first pair of coxio, oblong, searcely reaching the apex of the clypons; first femorn scarcely dilited bencath, armod with a small minute tooth near the apex; tibio simple, longer thian the first femorn, last pair 6-spined (Stål).

\subsection{Metaurus reticulatus, Stăl.}

Metaurus reticulatus, Stål, Berlin Ent. Zeitschr. x, p. 391 (1866).

q. Pale yellow-virescent: tegnina pale yellow-greenish-hyaline, veins greenish; wings somewhat colourless : the small tubercle placed on the gene hefore the npper part of the eyes and a small anterior spot on the sides of the thorax behind the eyes, black and shining : cephalic process short, slender, twice as long as the thorax, turning upwards; frons oblong, very slightly roundly amplified towards the apex, narrowed above the middle: thorax with a somewhat indistinct ridge: scntellum slightly tricarinate : tegmina gradually somewhat amplified towards the apex; stigma with eight veins (Stål). Long, 11 ; exp. teg., 32 mil-
lims.

Reported from Cambodia.

\section{$\checkmark$ OGenus Anagnia, Stål.}

Stettin Eut. Zeit. xxii, p. 149 (1861); Hem. Afric. IV, p. 151 (1866).

Head prominent before the eyes; frons elongate, tricarinate; cly. peus marginate, carinate in the middle : pronotum carinate in the middle, posteriorly angularly-emarginate, anteriorly behind the head, obtusely angularly-prominent: tegmina extending much beyond tho abdomen, longitudinal veins on corium forked and united with some fow trinsverse veinlets towards the apex: feet rather long, slender, first pair of femora dilated beneath, last pair of tibiæ multispinose allied to Pictyophura (Stål). 
$\checkmark$ 23. Anatiala splendens, Germar.

$\checkmark$ Flata splendens, Germar in Thon's Archiv. ii, fasc. 2, p. 48 (1830) : Walker, List IIom. 13. M. ii, p. 310 (1851).

$\checkmark$ O Pscudophana splendens, Westwood, Truns. Liun. Soc. xviii, p. 151 (18.41).

$\checkmark$ O Diclyophora indliuna, Walker, 1. c. p. 310 (1851).

Anaynia splendens, Stàl, Stettin Ent. Zcit. xxii, p. 149 (1861.)

§, \&. Greyish-flavescent, sprinkled fuscous; a stigmatic spot on the tegmina and interior streak belind the middle, a small subapical streak on the wings, fuscous ; anterior tibix ringed black, last pair with

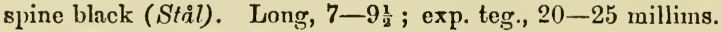

Reported from Manilla, Java, Bombay, Iudia.

\section{Genus Centromeria, Stål.}

Ofrers. K. V.-A. Förh. p. 745 (1870).

Body somewhat elongate: head produced, ascending more or less before the eyes, gradually narrowed: vertex somewhat equal in brealth to the eyes, grndually acuminated before the eyes; frons tricarinate, tho median ridge running through it very distinct, lateral ridges extended through half of the upper frons, less elevated; n distinct rillge running through the clypeus : thorax unicarinate, posteriorly broally angularly sinuated: scutellum tricarinate: tegmina gradually amplified towards the apex, apical part furnished with numcrous transverse veins ; the veins of the clavus united behind the middle; interior uhar vein forked at almost tho same distance from the base and from the united claval veins; radial vein forked a little behind the middle of tho tegmen ; stigma elongate or oblong, with some veins : feet long, slender ; first pair of femora beneath near the apex with a very minute, acuto spinule. Nenr to Oictyophara, Germar, the fcet are longer and moro slender and the first pair of femora spined (Stril).

\section{- 24. Centromeria speilinea, Walker.}

$\checkmark$ O Dictyophora speilinea, Walker, J. Linn. Soc. Zool. i, p. 8\& (1856).

Green: lead, three ridges on the pronotum (the lateral pair marginal) and three on the mesonotum also its siles in part, cmerald-green : head with three ridges above and one beneath and two rilges on pronotum near the lateral emerald-green rilges, lutcous: cephalic protuberance lanceolate, ascending, as long as the hind part of the head: fore tibire and tarsi, tawny : tegmina and wings limpid, veins and stigma green, the latter occupying three areolas (Walker). Body long, $10 \frac{1}{2}$ : exp. teg., $29 \frac{1}{2}$ millims.

Reported from Singnpore.

16 
Dictyophora, Germar, Silb. Rov. Ent. i, p. 165 (1833): Walker, List Hom. B. M. ii, p. 307 (1851).

Vo Dyctiophora Spinola, A. S. E. F. (1 sér) viii, p.

Bnrm. Handb. Ent. ii (i) p. 159 (1895) (1843): : Chanithus. Hist. Nat. Ins. Hém. p. 506 Ent. vii, p: Sta Stål, Hem. Afric. iv, p. 15 t (1866) : Fieber, Rev. Mag. Zool. (3 sér.) iii, p. 357 (1875).

Body oblong or oval, a little depressed : head not or only very slightly callous behind the eyes, varying very much in form, abruptly truncated before the eyes or more or less to a distance protuberant, the protuberance straight or recurved : vertex and frons very often carinated: clypeus long, carinated in the middle : second joint of antennæ small, subglobose : rostrum long : thorax very often broadly emarginated at the base, slightly sinuated anteriorly belind the eyes, tonching the entire posterior margin of the head, furnished with $1-3$ ridges : scutellum very often tricarinated. Tegmina very often extending beyond the apex of the abdomen, third part or barely apical half furnished with transverse veins; clivus without a transverse vein : feet moderate or longish, slender, simple; first pair of femora unarmed, shorter than the tibiæ, last pair of tibio 4-6-spinose : exterior radial and ulnar veins contiguous at the base (Stål).

\section{$\checkmark 0^{25}$. Dictrophara lineata, Donovan.}

$\checkmark{ }^{\circ}$ Fulgora lineata, Donovan, Ins. India, t. 8, f. 1 (1800); Westwood, Trans. Linn. Soc. $x$ viii, p. 147 (18+1).

$\checkmark$ Fulgora pallida, G. Gray, Griffith, An. King., Ins. ii, p. 260, t. 90, f. 2 (1832).

$\checkmark$ Dictyophora lineata, Walker, Cat. Hom. B. M. ii, p. 310 (1851).

Cephalic process linear, ascending; tegmina pale with two brown lines (Donovan). Pale testaceous or fulvons-whitish: cephalic process as long as half the body, ascending, pale greyish-luteous; slender, a little thickened at the apex : tegmina narrow, elongate, whitish, with blackish dots arranged in lines towards the internal and external margin of the posterior part of the tegmina, also a narrow black line towards the base of the costa : cephalic process and feet, punctured black: last femora at the apex and the tarsi broad (Westw.) Body long with cephalic process (wings closed), $12 \frac{1}{2}$ millims.

Reported from Bengal. In Donovan's figure, the black spots on the tegmina appear to be confluent forming two lines and extending throughont the entire length of the tegmina: the Indian Museum possesses a specimen from Sibságar (Assam). 
0 26. Dictyopilara paleida, Donovan.

$\checkmark$ Fulgora pallida, Donovan, Ins. India, t. 8 f. 2 (1800).

$\checkmark$ Pseudophana pallida, Westwood, Trans. Linn. Soc. xviii, p. 150 (1811).

$\checkmark$ Dictyophora pallida, Walker, Cat. Hom. B. AI. ii, p. 310 (1851) : nec D. pallida Walker, l. c. p. 320 .

Cephalic process linear, ascending: thorax pale green, with red lineations; tegmina hyaline (Donovan). Size of preceding, but easily recognized by the longitudinal red lines on pronotum and prostethium. Body long with cephalic process, $12 \frac{1}{2} ;$ to end of closed tegmina, $19 \frac{1}{2}$ millims.

Reported from Bengal: the Indian Museum possesses speciniens from Rániganj (Lower Bengal).

\section{$\checkmark 0_{27}$. Dictyophara graminea, Fabricius.}

$\checkmark 6$ Fulyora graminea, Frabricius, Syst. Rhyng. p. 4. (1803).

$\checkmark$ o Flata graminea, Germar in Thon's Archiv. ii. fisc. 2, p. 17 (1830).

$\checkmark$ o Pseudophana graminea, Burm., Handb. Eut. ii (2) p. 160 (1535) ; Westwood Trans. Linn. Soc. xviii, p. 150 (1811).

$\checkmark$ D Dictyophora graminea, Walker, List. Hom. B. M. ii, p. 309 (1851).

Cephalic process porrect, bicarinate broadly above: tegmina and body green, immaculate ( $\mathrm{Fabr}$.).

Reported from India.

\section{$\checkmark \circ 28$. Dictyophara Despecta, Walker.}

$\checkmark$ Dictyophora despecta, Walker, List. Hom. B. M. ii, p. 31 t (1851).

ठ. Body tawny : head quite four times longer than the pronotum; the cephalic protuberance continued in a line with the pronotum, almost prismatic, slightly tapering from the base to the tip which is rather obtuse : angles green : pronotum slightly conical in front, mucli sinuated on the hind border, adorned with five bright green stripes; a slight oblique ridge on each side : mesonotum with three bright green stripes and a green spot on each side : abdomen obconical, a little longer than the thorax : legs pale tawny, slender, slightly grooved; hind tibiæ armed with four black-tipped spines : wings colourless, a slight tawny tinge on the tegmina; stigma tawny, occupying parts of $2-3$ areolas : veins brown, tawny towards the base (Waller). Body long, $10 \frac{1}{2}$; teg., $16 \frac{1}{2}$ millims.

Reported from Malabar coast.

\section{$\checkmark$ o 29. Dictrophara sinica, Walker.}

$\checkmark$ O Dictyophora sinica, Walker, List. Hom. B. M. ii, p. 321 (1851); Stål, Ofvers. K. V. A. Förh. p. 487 (1862). China.

$\checkmark$ Dictyophora inscripta, Walker, l. c., p. 322 (1851). Hong Kong.

$\checkmark$ O Dictyophora insculpta, Walker, 1. c., Suppt. p. 67 (1858). N. China. 
Burly pale luteous, nlmost fusiform : head abovo with a short greon stripe which does not extend beyond the vertex, tho lateral edges of which

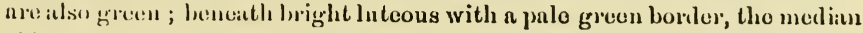

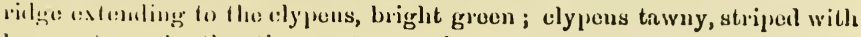
brown fowards the lip: restrum julo tawny : promotum striped green; musmot um with tlueo indistinct green stripes : alshomen green, a brown stripe on the dise, pate lawny at tho tip: logs polo tawny, partly striped with hawn; hind tibie with four blnck-tipped sppines: termina mat wings coloniless, the lipss of tho former pulo yollowish-brown; stigmn brown oecrupging flure areolas; veins green, brown towards tho tips

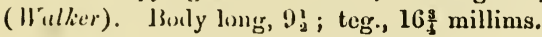

lieported from China: Assam (?).

\section{Yo 30. Dictyophara (?) nigriacula, Walker.}

I r. Diclyophora nigrimacula, Walkor, List. IIom. B. M. ii, p. 318 (1851).

ơ. Boily fusiform: head as long as the thorax tapering slightly to the tip which is obtuse, slightly elevated; cephalic protuberaneo trunsversely striated alove aml on each side; upper side ferruginous; vertex with a medium stripe, yellow, and lateral strijes, green, which last aro omulinul along near haif the length to the tip; a black median stripo extemuls lrom tho vertex to the tipe towards which it oecnpies tho whole dise; siles black wilh tawny borders: nuder-sido bright orango rel, having on cach sille a tawny brown-spotted stripo which in its comse becomes luight green and is continued along tho elypens; the luright green milllle-riclgo also extends along the whole leugth and is palo yelluw at cach end; the under side slightly widens along tho wholo lengils from the $t i p$ to the elypens, with tho exception of a slight eontaction between the eyes: elypous roddish at its hase, lown with yellow stripes lowials its tip : rostrum tawny wilh a black tip, reaching the hind eoxiv: promolum ferruginons, slightly widenod and almost monlar in front, slightly simnted along the posterior margin, with tive bright green riclges : the imer pair a little oblique, the onter pair more oblique and priallel to the sides which are green; the space beneath on each sile of the eyes is pyriform, red, with a green horder and a bright green melliun silipe: mesomolum black along tho anterior margin, with three bright green slighlly interrupted stripes; on each side near the base of the frgmen is a liriglit green spot; beneath black with a few yellow stripes and a furnginous border: abdomen black, obconical, a little longer than the thorax with five rows of greenish-tawny spots, those of the midlle row are stencler and form a slightly interrupted stripe, tho oflurs are irregnlar and much emarginated: legs tawny, slightly sroused, striperl black, fect black towards the tips, posterior tibio armed 
with firo black-tipped spines; hind-feot nuch dilaterl: tegminn and wings colonrloss, tips of the formor brown, stigmn very rlark occupying 3-t areolets, veins black, greonish-tawny at tho baso ( $\mathrm{V}_{\text {allker }}$ ). Borly long, $10 \frac{1}{2}$; leg., 21 millims.

Ireported from N. Indin.

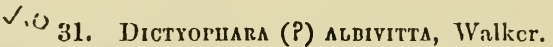

Dictyophora albititta, Walker, List. Hom. B. M. ii, p. 319 (1851).

\$. Body tawny, fusiform : head abovo with three green stripes, median more distinct; beneath with a bright green ridge and on encl sirlo a pale green stripo, the three continued throughout the whole lenglh and through a part of the clypens: rostrum tawy, tip black, extenting

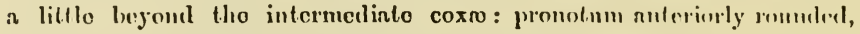
not conical, slightly simunted nlong tho himl boreler which like Iles sirles is grecu : disc with tivo bright greon stripes, inner pair anverl, slightily al-

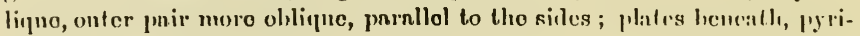
form, horlered with green and with green atripe : mesmotum with threo

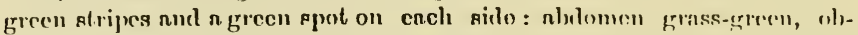
conical, motlled yellow, tarny at tho tip with three parallel indistinet whitish stripes: legs pale tnwny, partly grecn, slightly growert ; frumin nud anterior tibio striped brown, posterior tilia nrmed witl fire lilacktipped spines; posterior feet much dilated: tegmina aur wings colourless, the former slightly tarny at tho tip; stigma tawny occulying two areolets and part of a third ; veins pale greenish-tawny, darlier towarls tho tips (IIalker). 13oly long, $10 \frac{1}{8}$; teg., 21 millims.

licported from N. Bongri.

\section{$\checkmark 0$ 32. DictTopiLARA TALKERI, n. FJ.}

Dicfyophora pallida, Walkor, List B. M. ii, p. 320 (1851); nen Denovan.

8. Body fusiform, palo luteous: tip of vertex, black: heat alovo with a bright green stripo along each edgo and with a short green median stripo which does not extend beyond the eyes; sirles green; heneatil bright luteons with three bright green ridges which are continuch alongr part of the clypens : rostrum tawny, tip black, reaching nearly to tho last coxm : pronotum hardly conical in front, slightly simuale posteriorly, bordered with green, with five bright green stripes, sicle plites pyrifurm with green margins and a bright green median stripe : messmotmu with three and the sides with two green stripes : alulomen obeonical, a lit.le longer than the thorax, jellow with whitish stripes, luteous towarls the basc, tawny at the tip : posterior margins of the secrments grass-erecu : lega slender, slightly grooved, dull palo yellow, tingeul with green; tijes 
of the foet and of the fore tibio, brown; hind tibiø armed with four black-tipped spines; lind feet moderately broad: tegmina and wings colourless, a slight tawny tinge on the tips of the tegmina, stigma pale brown, occupying two areolets and part of a third; veins green, brown towards the tips (Walker). Body long, $7 \frac{1}{4}$; teg., $14 \frac{3}{4}$ millims.

Reported from N. India.

\section{$\checkmark{ }^{\circ} 33$. Dictrophara LePtormina, Walker.}

$\checkmark \odot$ Dictyophora leptorhina, Walker, List Hom. B. M. ii, p. 321 (1851).

$\delta$. Body tawny, fusiform : cephalic prolongation with the four sides of equal breadth with green edges, a green stripe above, distinct only on the vertex, that beneath appearing along the whole length to the clypeus which is brown : rostrum tawny, tip black, reaching the hind coxæ : pronotum rounded in front, more slightly sinuate belind, with green ridges which also appear on the mesonotum : abdomen green, obeonical, slightly luteous towards the base, longer than the thorax : legs pale tawny, slightly grooved; femora striped black; hind tibiæ armed with five black-tipped spines; hind feet much dilated : tegmina and wings colourless; stigma brown, colouring the borders but not the dises of three areolas; veins of the tegmina brown, green towards the base; veins of wings, black (Walker). Body long, $9 \frac{1}{2}$; teg., 19 millims.

Reported from Java : with the thorax luteous, from India.

\section{$\checkmark$ ○3. Dictyopmara sadropsis, Walker.}

Dictyophora sauropsis, Walker, Jour. Ent. i, p. 306 (1862).

§. Tawny: head forming a long, quadrilateral, slightly tapering cone, which has a rim on both sides, above and beneath; underside reddish ochraceous, with three other pale ridges: pronotum arched, more than four times as broad as long, with a median ridge: mesonotum bicarinate: tegmina and wings einereous hyaline; veins black, pale tawny towards the base; transverse veinlets incrassated : tegmina with

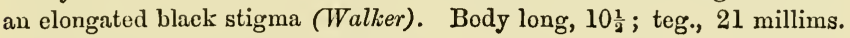

Reported from Dacca (Bengal).

\section{○ 35. Dictyophara patroelis, Stål.}

Pseudophana patruelis, Stål, Freg. Eng. Res. Ins. p. 271 (1859).

Dictyophara patruelis, Stål, Rio Jan. Hem. ii, p. 63 (1862).

ð. Weakly miniaceous : vertex, abdomen, and feet sordid weak flavescent: frons, clypeus, thorax, scutellum, and pectus with grass-green ridges: togmina vitreous, veins and stigma fuscoys: head as long as the thorax and scutellum taken together. Close to D. sobrina, Stâl, but 
smaller and head shorter :head test aceous-flavescent; vertex with a longitudinal ridge between the eyes; frons, clypeus, and thorax miniaceous, the two former with ridges, the last with a median ridge, an oblique line on both sides and a lateral ridge and the lateral margins, grass-green : seutellum weakly miniaceous, with three parallel ridges and a posterior spot on each side, grass-green : tegmina almost twice as long as the abdomen, sordid vitreous, the third apical part transversely veined; veins and stigma fuscous: pectus weakly miniaceous with a grass-green ridge on both sides : abdomen and feet weak sordid virescent-flavescent, the disc of the abdomen and the apices and lines on the feet, black-fuscous (Stål). Body long, 8 ; broad, $2 \frac{1}{4}$ millims.

Reported from Malacca.

\section{- Subfam. Crxinna, Stâl.}

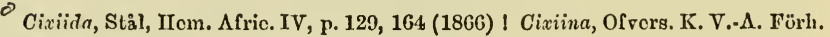
p. 7.16 (1870).

Similar to Dictyopharina except that there are usually threc ocelli, one of which is placed on the apex of the frons: this frontal ocellus is very rarely wanting and if wanting the sides of tho clypeus are convex and ccarinate (Stål).

\section{Genus Cixıos, Latreille, Stål.}

Gen. Ins. iii, p. 166 (1807); Guérin, Voy. Bélanger Ind. Orient. Zool. p. 463 (1834) ; Burm., Handb. ii (i) p. 156 (1835) : Stål, Hem. Afric. iv, p. 164, 169 (1866) : Fieber, Rev. Mag. Zool. (3 sér.) iii, p. 355 (1875).

Head somewhat narrower than the thorax, short, roundly simated at the base; vertex somewhat concavish; frons and clypeus together elliptieal, furnished with a median ridge running through them; frons with an ocellus on the apex, sides of elypeus carinated: eyes slightly or only very slightly sinuated beneath : antennæ inserted beneath the eyes, very short, first joint concealed, second small, subglobose: thorax very short, posteriorly, deeply, angularly emarginated : scutellum triearinate lateral margins of tegmina parallel, interior ulnar vein and the radial vein forked at a distance from the base : feet moderate, simple, last tibix armed with 2-3 spines (Stål).

\section{- 36. Cixids (?) Albistriga, Walker.}

Cixius albistriga, Walker, J. Linn. Soc. Zool. i, p. 87 (1856).

Blackish, testaceous beneath: head much smaller and frons narrower than in European species; frons dark brown : posterior margins of abdominal segments reddish above, whitish beneath: tegmina brown 
with three whitish transverse streaks towards the tip of the costa: wings grey (Walker). Body long, $t_{\frac{1}{4}}$; teg., $10 \frac{1}{2}$ millims.

Reported from Singapore: a specimen doubtfully assigned to this species has been received from Burma, but is probably a Brixia.

$\sigma$ 37. Cixius (?) caudatus, Walker.

Cixius caudatus, Walker, Ins. Sannd. Hom. p. 43 (1858).

Tawny : vertex depressed, longer than broad, its borders elevated frons and face forming a fusiform compartment with a median ridge: pronotum arehed, very narrow in the middle; mesonotum 5-carinate, the external pair of ridges angulate, a brown stripe interlined with tawny on each side: oviduct extending far beyond the abdomen, sheatlis brown: legs testaceous: tegmina with a brown stigma, veins testaceous with black dots, some black streaks also on the dise before the midule and the transverse veinlets and some parts of the exterior veins elouded with browu: wings with black veins (Walker). Body long, $4 \frac{1}{4}$; teg., $12 \frac{1}{2}$ millims.

Reported from India.

38. Cixios (?) efferatus, Walker.

Cixius efferatus, Walker, J. Linn. S. Zool, i, p. 87 (1856).

Testaceous: frons subfusiform, attenuated in front: eyes largo nearly contiguous on the vertex : abdomen tawny: tegmina and wings limpid; veins tawny; stigma testaceous, with a brown spot elose to its tip and opposite a smaller and paler brown spot on the interior border : wings with a brown streak at the tip of the costa (Walker). Body long, $5 \frac{1}{4}$; exp. teg., $12 \frac{1}{2}$ millims.

Reported from Siıgapore.

\section{c Genus Oliarus, Stål.}

Berlin Ent. Zeitschr. vi, p. 306 (1862); Hem. Afric. iv, p. 164, 166 (1866); Ilem. Fabr. ii, p. 92 (1868) : Fieber, Rev. Mag. Zool. (3 ser.) iii, p. 356 (1875).

Head somewhat narrower than the thorax, angularly emarginate at the base; vertex varying in length and breadth, concave; frous and clypeus together elliptical, furnished with a distinct, median, longitudinal ridge running through them, lateral margins rounded, slightly dilated ; frons with an ocellus on the apex; sides of clypeus ridged: eyes scareely or but slightly sinuated beneath : antennæ very short, inserted beneath the eyes, first joint hidden, second somewhat globose, small : thorax very sliort, posteriorly deeply angularly sinuated : seutellum with five ridges: tegmina rouncled at the apex; radial and exterior ulnar vein contignous at the base itself, radial and interior ulnar vein forked at a more or less 
distance before the midlie of the tegmina : fect moderate, single; last pair of tibia, 2-3-spinose (Stål).

\section{Oliarus walkeri, Stål.}

0 Cixius walkeri, Stål, Freg. Eng. Resa. Iem., p. 272 (1859).

Oliarus valkeri, Stål, Berlin Ent. Zeitschr. vi, p. 306 (1862).

$\delta$. Obscurely testaceous; frons and feet testaceous-yellow : tegmina weak vinaceous-hyaline; veins concolorous, remotely punctured fuscous behind the middle; the five apical transverse veins clothed fuscous; stigma weak testaceous-yellow, inwardly narrowly fuscous : head yellow-testaceous; vertex almost twice as long as broad with two ridges running forwards from the middle, converging; frons with the oval clypeus narrowed at base and apex, a single forked ridge at the base itself : thorax very short, posteriorly angularly-sinuated, testaccous, with five rillges of a lighter colour of which the lateral pair diverge somewhat towards tho apex : teginina with the veius concolorous, fuscous at the apex; beneath with feet pale testaceous-flavescent; pectus black-fuscous (Śtal). Long, 4 ; broad, $1 \frac{1}{2}$ millims.

Reported from Malacca, Manilla.

- 40. Oliarus bomemani, Stål.

${ }^{\circ}$ Cixius bohemani, Sti̊l, Freg. Eng. Resa. Hem., p. 272 (1859).

Oliarus bohemani, Stål, Berlin Ent. Zeitschr. p. 306 (1862).

$\delta$, ㅇ. Blackish : ridges on the head, incisures on abdomen and the tibir, pale testaceous-yellow, tegmina weak vinaceous hyaline, veins remotely punctured fuscons. Head blackish; vertex longer by half than broad with a less elevated longitudinal ridge and another transverse arched one belind the apex; frons and the oval clypeus with a single longitudinal ridge, forked at the base itself : thorax very short, testaceous yellow, posteriorly angularly-sinuated : scutellum blackish, somewhat parallel, with five ridges, of which the lateral pair converge somewliat at the base and apex : the tegmina twice as long as the abdomen, very weak fuscescent hyaline towards the apex; veins remotcly punctnred, fuscous at the apex; clavus with a median dot and obliquely behind it a dot also on the corium, fuscous : beneath black-fnscous : feet pale testaceous yellow, femora fuscous-testaceous (Stål). Long, $3 \frac{1}{2}$; broad, $1 \frac{1}{3}$ millims.

Reported from Hong-Kong.

\section{a Genus Brixia, Stål.}

Ofvors. K. V.-A. Förh. xiii, p. 162 (1856) ; Freg. Eng. Resa, p. 276 (1859); Hem. Afric. iv, p. 166, 173 (1866) : includes Triopsis, Sign., A. S. E. F. (3 sér.), viii, p. $187(1860)$.

24 
Head much narrower than the thorax; vertex narrow, compressed, narrower by half than the eyes, passing over into the frons which is long, gradually narrowed upwards, much compressed between the eyes, without a ridge, furnished with an ocellus at the apex; median ridgo of clypens less distinct, latcral margins carinated : eyes beneath sinuated: antenuw inserted beneath the eyes, first joint exserted, second longer than thick: thorax very short, angularly emarginated at the base : scutellum tricarinate: tegmina gradually somewhat amplified towards the apex; radial and exterior ulnar vein united near the base : feet moderate, simple; last tibio unarmed (Stål).

\section{- 41. Brixia meander, Walker.}

C Cixins meander, Walker, List Hom. B. M. ii, p. 349 (1851).

Brixia meander, Stål, Ofvers. K. V.-A. Förh. p. 487 (1862).

Body tawny: frons long and narrow with a row of brown spots along each side of the diso which is also brown : rostrum tawny: eyes large : pronotum on both sides obliquely tricarinate: disc of the mesonotum brown : legs tawny, slightly sulcated : each femur with two brown rings : tegmina almost colourless, adorned with several waved brown bands which are partly confluent or interrupted, discs of the spaces between them occupied by paler brown bands : a large yellow spot on the anterior margin: veins pale stramineous, thickly dotted with black knots (Wallier). Body long, $4 \frac{1}{4} ;$ teg., $10 \frac{1}{2}$ millims.

Reported from India.

\section{- Genus Benna, Walker.}

J. Linn. Soo. Zool. i, p. 90 (1856) : Stål, Hem. Afrio. iv, p. 166 (1866).

Body rather slender, head a little narrower than the thorax with a ridge which extends from the back of the vertex to the rostrum; sides also ridged; frons compressed, elongate-subfusiform : $1-2$ joints antennæ a little shorter together than the breadth of the front; filament not long: thorax tricarinate, pronotum very short: abdomen at the base with two lateral capitate appendages like the halteres of Diptera, tip terminating in a long, curved oviduct: legs rather long and slender: tegmina and wings broad, rounded at the tips, the former with about twenty areolets, the discal generally shorter than the basal and marginal. (Walker.)

Frons with a longitudinal ridge narrowed upwards, scarcely distin. guishable from the vertex : first joint of the antennæ prominulous, second longer than broad: abdomen furnished on both sides at the base with a long, filiform, clavate process : tegmina gradually amplified from the base towards the apex; the costal margin slightly sinuated towards the base; the radial and ulnar veins separately emitted from the ulnar trunk or s:mewhat contiguous at the base itself (Stal). 
42. Benna capitulata, Walker.

Benna capitulata, Walker, J. Linn. Soc. Zool. i, p. 90, t. 3, f. 3, (1856).

ㅇ. Testaceous : abdomen with long cottony secretions; capitate appendages with white tips: tegmina and wings hyaline, the former with a very slight testaceous tinge; veins brown, testaceons towards the base and in the front, with a black basal dot and two smaller brown dots near the base: the transverse veinlets partly clouded brown, a brown streak along the exterior border; stigma testaceous (Walker). Body long, $6 \frac{1}{4}$; teg. $16 \frac{1}{2}$ millims.

Reported from Singapore.

- Subfam. Delphacina, Stål.

ODelphacida, Stål, Hem. Afric. iv, pp. 131, 175 (1866), Delphacina, Ofvers. K. V.-A. Förh., p. 747 (1870).

Distinguished by having the last pair of tibiø furnished with a mobile spur (Stål).

\section{O Genus Hrarops, Guérin.}

Ugyops, Gnérin, Voy. Bél. Ind. Orient. p. 477 (1843); Spinola, A. S. E. F. viii, p. 321 (1839); Walker, List Hem. B. M. ii, p. 338 (1851): Hygyops, Stål, Hem. Afric. iv, p. 175 (1866) : inclndes Bidis, Walker, J. Linn., Soc. Zool. i, p. 88 (1856) । Hygiops, Am. \& Serv., Hist. Nat. Íns. Hém. p. 511 (1813).

Antennæ inserted below the eyes, almost as long as the body; two first joints equal, cylindrical, with the filament inserted at the tip of the second joint, which is granulate; eyes very slightly emarginate beneath ; apparently no ocelli: frons narrow, a little ascending, anteriorly much longer than broad, a little dilated in the middle, longitudinally grooved : rostrum as long as the head, covered at its baso by a pointed, oblong labrum : pronotum narrower than the mesonotum, a little emarginate posteriorly : mesonotum triangular, apex pointing behind : tegmina narrower than the wings, oblong: abdomen flattered, feet long, spinose (Guérin).

\section{- 43. Hygyops percheronit, Guérin.}

○ Ogyops percheronii, Guérin, Voy. Bél. Ind. Orient. p. 478 (1834); Icon. Règne Anim., t. 58, f. 16 (1830-34); Burm., Handb. Ent. ii (i), p. 152, (1835); Spinola, A. S. E. F. viii, p. 323 (1839); Walker, List Hom. B. M. ii, p. 338 (1851).

○ Hygiops percheronii, Am. \& Serv., Hist. Nat. Ins. Hém. p. 512 (1843).

Ferruginous red, antennæ of the same colour, brown at the tip : tegmina and wings transparent, veins reddish: beneath and feet ferruginous (Guérin). Body long, 5 ; exp. teg., 16 millims.

Reported from Cochin China.

26 
44. Hyayops notivena, Walker.

${ }^{\circ}$ Bidis notivena, Walker, J. Linn. Soc. Zool. i, p. 88 (1856).

Hygyops notivena, Stål, Hem. Afric. iv, p. 175 (1866).

$\delta, \uparrow$. Testaceons, partly green : tegmina and wings transparent, the former with a very slight testaceous tinge ; veins testaceous, here and there blackish : the of partly red (Walker). Body long, $4 \frac{1}{4}$; teg., $12 \frac{1}{2}$ millims. Reported from Singapore, Malacca.

\section{$\checkmark$ o Subfam. Achilina, Stàl.}

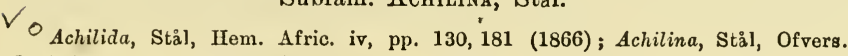
K. V.-A. Förh., p. 748 (1870).

Head narrower than the thorax; sides of the clypeus carinate: last joint of rostrum elongate: thorax angularly emarginate at the base: tegmina amplified inwards behind the clavus which is very rarely graunlated, acute at the apex, distinctly closed; the claval vein continued to the apex itself or united with the claval suture near the apex : last pair of tarsi with the first joint elongate.

\section{$\checkmark \therefore$ Genus Faventia, Stål.}

Hem. Afric. iv, p. 181 (1866); Ofvers. K. V.-A. Förh., p. 748 (1870).

Head narrower than the thorax; frons with a long and clypeus with a distinct ridge running through it, the lateral ridges on the clypeus not united at the apex: thorax very short, angularly emarginate at the base : scutellum tricarinate : tegmina roundly truncated at the apex; the interior ulnar and the radial vein forked before the middle: first tibiæ longer than the femora and trochanters taken together, the last pair unispinose (Stål). T'Type, C. pustulatus, Walker.

\section{$\checkmark$ ) 45 . Favientia pustulata, Walker.}

$\checkmark$ C Cixius pustulatus, Walker, J. Linn. Soc. Zool. i, p. 87 (1856).

Faventia pustulata, Stål, Berlin Ent. Zeitschr. x, p. 392 (1866).

Tawny, testaceons beneath : head greenish, with a black dot on each side, ridges ferruginous : tegmina with some paler marks and with many minute blackish dots which are accompanied by $2-3$ larger and

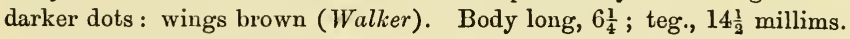

Reported from Singapore.

$\checkmark$ a Genus Helicoptera, Amyot \& Serville.

Hist. Nat. Ins. Hén. p. 526 (1813); Stảl, Hem. Afric, iv, pp. 181, 184 (1866) : includes Elidiptera, Spin., A. S. E. F. viii, p. 50! (1839); Walker, List Hom. B. M. ii, p. 328 (1851). 
Body depressed: head much narrower than the thorax, produced before the eyes; vertex posteriorly about twice as broad as the eyes, somewhat concave, not ridged; frons much longer than broad, distinctly narrowed upwards, more or less distinctly ridged in the middle; sides of clypeus ridged: eyes rounded, obsoletely sinuated beneath: second joint of the antennæ somewhat globose : thorax tricarinate, lateral ridges not reaching the base: scutellum tricarinate: tegmina rounded at the apex; the radial and exterior ulnar veins united at the base; radial and exterior ulnar vein forked rather far from the base: feet modorate, first tibir subequal in length to the femora and trochanters taken together; last tibiæ unispinose (Stål).

\section{Helicoptera? smaragdilinea, Walkcl.}

\section{Elidiptera smaragdilinea, Walker, J. Linn. Soc. Zool. i, p. 86 (1856).}

Ferruginous: head about the eyes and on each side of the frons, a spot in the middle of the pronotum and one on each side and a stripe on the mesonotum, emerald-green : cephalic protuberance, slender, cylindrical ascending, black above, green beneath, about twice the length of the head above ; frons long and narrow; face and pectus black and white : abdomen with a green stripe on each side and a black stripe on each side beneath : legs tawny, femora black at the base; tibir and tarsi partly green; fore tibiæ white towards the tips : tegmina and wings limpid, the former with a narrow brown streak along the terminal part of the costa, and with a broad brown streak along the corresponding part of the hind border, the two streaks connected by a brown streak along the transverse

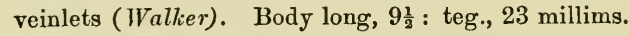

Reported from Mount Ophir, Singapore.

\section{$\checkmark$ Subfam. Tropiddchina, Stål.}

$\checkmark$ a Tropiduchida, Stål, Hem. Afric. iv, p. 130, 186 (1866) : Tropiduchina, Ofvers. K. V.-A. Förh., p. 748 (1870).

Head narrower than the thorax; sides of clypeus without a ridge or with an obtuse ridge: thorax very often angularly emarginate at the base, very rarely roundly sinuate, tricarinate; lateral ridges diverging, very often reaching the base; commisural margin of tegmina straight or rounded behind the clavus which is generally as in Achilina; costa sometimes dilated, costal membrane transversely veined; first joint of last tarsi elongate (Stăl). 
Genus Daradax, Walker.

J. Linn. Soc. Zool. i, p. 85 (1856); Stål, Hem. Afric. iv, p. 188 (1866).

Head lanceolate, ascending, cariuate on both sides; frons lanceolate, with a median and lateral ridges: antennø globose, vory minute, setiform filament moderately long, very slender: pronotum much arched with a slight median ridge, each side forming a fusiform compartment: mesonotum quadricarinate: tegmina fusiform, with numerous parallel equidistant veinlets along the costa; ulnar areas long; apical areas short, like those of the costa (Walker).

\section{$\checkmark$ 4.7. Daradax fusipennis, Walker.}

Daradax fusipennis, Walker, J. Linn. Soo. Zool. i, p. 86 (1856).

Green, partly lutescent: tegmina with brown dots along the exterior

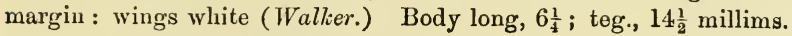

Reported from Malacca.

\section{$\checkmark$ Genus Tropidochus, Stål.}

Ofvers. K. Y.-A. Förh. p. 248 (1854); Hem. Afric. iv, p. 188 (1866) : includes Euria, Walker, J. Linn. Soc. Zool. i, p. 87 (1856).

Body oblong: liead somewhat narrower than the thorax, slightly prominulons before the eyes, obtuse: vertex arcuate, transverse, much broader than the eyes, deeply sinuated at the base, rounded at the apex; frons much longer than broad, somewhat narrowed upwards, with 1 or 3 ridges; clypeus with a median ridge, sides convex or obtusely ridged: rostrum somewhat short: second joint of the antennæ small, subglobose: thorax short, angularly emarginate at the base, tricarinate on the disc : scutellum tricarinate: tegmina not or but slightly narrowed towards the apex; costa remote from the margin, emitting outwards numerous trans. verse veins, radial and ulnar veins forked rather distant before the middle and at an equal length from the base; apical part with two rows of transverse veins : feet moderate; first tibiæ somewhat longer than the femora and trochanters taken together, last tibiæ trispinose (Stål).

\section{Vo 48. Tropiduchus LURIDUs, Walker.

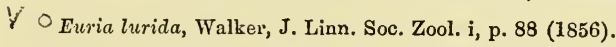

Brownish, paler beneath: head green with tawny ridges: tegmina and wings lurid, the former with four brown bands of which the first and second are dilated in front, the third is slender, curved, joined at each end to the second, the fourth is marginal : wings with three brown bands

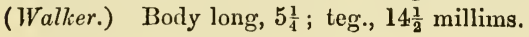

Reported from Singapore. 
Genus Elich, Walker.

J. Linn. Soc. Zool. i, p. 86 (1856).

Head conical, slightly ascending, tricarinate above: frons lanceolate, tetragonal, tricarinate, the lateral ridges curved, margins also ridged : antennæ conical, setiform filament twice as long as the preceding part: pronotum very short: mesonotum tricarinate: tegmina broad with numerous transverse veinlets along the costa ; ulnar areas elongate towards the base of the tegmina ; apical areas more numerous, short, and generally 5-6 angled (Wallier).

\section{Elica latipennis, Walker.}

Elica latipennis, Walker, J. Linn. Soc. Zool. i, p. 86 (1856).

Testaceous, partly tawny : head above and disc of the thorax, brown : tegmina hyaline with a slight testaceous tinge; veins tawny, some of them black, forming an irregular, incomplete band (Walker). Body ong, $7 \frac{1}{4}$; teg., 19 millims.

Reported from Malacca.

\section{$\checkmark \odot$ Genus Monopsis, Spinola.}

A. S. E. F. viii, p. 302 (1839) ; Amyot \& Serville, Hist. Nat. Ins. Hén. p. 507 (1843) ; Walker, List Hom. B. M. ii, p. 325 (1851).

Cephalic prolongation flattened above, ovally rounded anteriorly; the flat portion of the vertex has a median ridge dividing into two lines posteriorly which form a very pointed arch placed above another arch on the pronotum; frons broad with a median and two lateral ridges: eyes large, oblong: pronotum very narrow, emarginate posteriorly in an arch; mesonotum with three elevated lines: tegmina slightly crystalline and transparent almost as in the genus ${ }^{D}$ ichoptera; the great basal half with long cells, then comes a small elevated transverse line and then a great number of small and more or less quadrate cells : abdomen rather flat and oblong: feet moderate (An. \& Serv.).

$\checkmark \odot 50$. Monopsis viridicans, Stål.

Monopsis viridicans, Stål, Freg. Eng. Resa. Ins., p. 281 (1859).

Q. Weakly virescent : vertex nearly semicircularly produced before the eyes; frons one and half time longer than the breadth, carinated; thorax somewhat longer than the vertex, roundly produced anteriorly, tricarinate, the lateral ridges oblique: scutellum triearinate, the lateral ridges somewhat divergent towards the base, parallel, nearly three and half time longer than the breadth (Stål). Long with teg., 7 millims.

Reported from Hong-Kong, Sikkim (?). 


\section{$\checkmark^{\circ}$ 51. Monopsis (?) sinion, Walker.}

Afonopsis sinica, Walker, List Hom. B. M. it, p. 327 (1851).

9. Body fusiform, yellowish-green: head and thorax tawny above, the former surrounded by a bright green ridge on each side and in front and with three others of which the lateral pair do not extend be. yond the disc from the hind border: pronotum with three bright green ridges, the side pair oblique, longer than the median one : rostrum and legs pale yellowish-green : feet tawny; hind tibiø between the middle and the tips, with three spines having black tips: tegmina and wings colourless, the basal part of the former pale green, occupying two-thirds of the surface, covered with little tawny tubercles, very distinct from the reticulated part; veius green. Body long $3 \frac{1}{2}$; exp. teg., $10 \frac{1}{2}$ millims.

Reported from Hong-Kong.

\section{$\checkmark \circ$ Genus Hrracia, Walker.}

J. Linn. Soc. Zool. i, p. 154 (1857).

Body elliptical convex : head with the borders hardly elevated; vertex conical, distinctly tricarinate; frons and face indistinctly tricarinate, the former obconical, excavated next the face which is lanceolate: pronotum full twice broader than long, narrower in front, 5 -carinate; mesonotum triangular, acuminate, tricarinate : tegmina acuminate with numeruus rugulose veins and transverse veinlets (Walker).

\section{Hiracia Walkeri, Signoret.}

Hiracia walkeri, Signoret, A. S. E. F. (4 sér.) i, p. 57, t. 2, f. 3 (1861).

Yellowish-grey with two black patches on the tegmina : head weakly angular in front with a median keel on the frons: vertex grooved with the margins strongly carinated, posterior margin concave : pronotum angular, rounded in front, furnished with a great number of small tubercles along the anterior margin and on its disc and a median transverse impression: scutellum weakly tricarinate: tegmina with veins without anastomoses but faintly reticulated in the intervals, a median triangular black spot towards costal margin and an oblong spot behind towards the internal margin; abdomen yellowish, shorter than the tegmina; feet yellow, very long; posterior tibiæ furnished on the external sides with seven spines, a character which serves to separate this species from H. ignava, Walker, from Borneo (Sign.). Body long, 7 ; broad, 3 millims.

Reported from India. 
- Subfam. Derbina, Stål.

- Derbida, Hem. Afrio. iv, pp. 130, 192 (1866); Derbina, Ofvers. K. V.AA. Förh p. 750 (1870).

Head very often narrower than the thorax : sides of clypeus sometimes carinated : last joint of rostrum short or very short; thorax posteriorly angularly-emarginate, ecarinate or furnished with an obsolete ridge : costa simple; clavus generally as in Achilina: last tibiæ very often unarmed, rarely spinose; first joint of last tarsi, elongate (Stål).

\section{- Genus Phenice, Westwood.}

Tranø. Linn. Soc. xix, p. 10 (1845); Stàl, Ofvers. K. V.-A. Förh. p. 163 (1856); Hem. Afric. iv, pp. 192, 195 (1866). Amyot \& Servillo [Ilist. Nat. Ins. Hém. p. 515 (1813) ] nnite Phenice with Derbe, Fabr. for reasons given; tho remainder of the species described are chiefly African.

Body oval: head much narrower than the thorax, seen from tho side, more or less rounded anteriorly, slightly compressly prominulous before the eyes; vertex and frons very narrow, the latter linear with the lateral margins sometimes contiguous; clypeus long, tricarinate: eyes posteriorly sinuate beneath, extended to a distance downwards : no ocelli : second joint of the antennæ varying in length, oval or a little elongate, without a sinus at the apex above: last joint of rostrum very minute : thorax short, posteriorly deeply angularly-emarginate : scutellum obsoletely tricarinate: tegmina elongate, gradually amplified from the base to the middle, thence somewhat narrowed or furnished with parallel sides, much longer than the wings; clavus short; radial rein forked, uluar vein emitting inwards obliquely longitudinal branches towards the commissural margin, these branches united by a transverse vein : feet slender, last tibiæ sometimes spinose (Stål).

\section{O 53. Phenice mesta, Westrood.}

O Derbe (Phenice) masta, Westwood, A. M. N. H. (2 sér.) vii, p. 209 (1851).

\& Derbe mresta, Walker. List Hom. B. M. ii, p. 397 (1851).

Phenice moesta, Stål, Ofvers, K. V.-A. Förh. p. 750 (1870).

Black, variegated white: a narrow frontal ridge on the head and the penultimate joint of the rostrum, whitish: three very fine ridges on the mesonotum and the posterior margin broader in the middle, white: feet white: tegmina black, costa and last half spotted white: wings smoky : lateral anal appendages in $\delta$, straight, incurved at the apex and

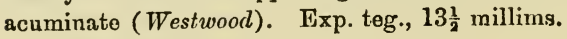

Reported from India.

32 


\section{Pifenice carnosa, Westiwood.}

D Derbe (Phenice ?) carnosa, Westwood, A. M. N. II. (2 sór.) vii, p. 209 (1851).

Entirely luteous flesh-coloured; four anterior tibiæ, fuscous: tegmina and wings yellowish hyaline, costal margin behind the middle of the tegmina and external margin of the wings, fuscous, the latter with a median black dot : apical joint of rostrum, black : anal appendages in $\delta$, elongate, curved, forcipate: abdomen in $q$ terminated by two porrect horns (Westwooll). Exp. teg., 14 $\frac{1}{2}$ millims.

Reported from India.

\section{OSubfam. LopHopina, Stål.}

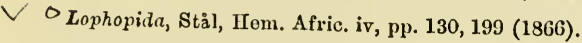

Head narrower than thorax, sides of clypeus carinate; rostrum short, stout, last joint very short; thorax truncate at the base, carinated or tuberculated on the disc; first joint of last tarsi robust, less long.

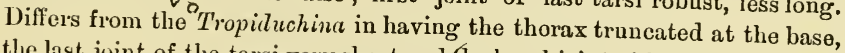
the last joint of the tarsi very short and the basal joint of last tarsi stoutish short or somewhat shortish : from the Issina in having the thorax distinctly tricarinated or tuberculated on the disc, the tegmina rather ample, flat, and extending much beyond the apex of the abdomen and from the O Ricaniina in having the thorax truncated at the base, dise distinctly carinated or tuberculated and last joint of rostrum very short (St\&l).

\section{$\checkmark \circ$ Genus Lacusa, Stål.}

Berlin Ent. Zeitschr. vi, p. 309 (1862); Hem. Afrio. iv, p. 199 (1866).

Head somewlat narrower than the thorax; vertex not produced, somewhat transverse, lateral margins not dilated; frons elongate, furnished with two rilges converging upwards ; clypeus carinate in the middle and on both siles: thorax truncated at the base, rounded anteriorly behind the vertex, tricarinate: scutellum tricarinate: tegmina rather ample, costal and commissural margins parallel, broadly rounded at the apex, costal limbus obliquely, transversely veined : anterior feet much dilated, foliaceons : last tibiæ trispinose, gradually slightly dilated towards the apex (Stål). Allied to ${ }^{\circ}$ Elasmoscelis, but distinct in tho structure of the head.

\section{l. 55. Lacusa fuscofasciata, Stål.}

\footnotetext{
$\checkmark{ }^{C}$ Elasmoscelis (?) fusco-fasciata, Stål, Ofvers. K. V.-A. Förh. p. 248 (1854).

$\checkmark \circ$ Cixius eminens, Walker, Ins. Saund. Hom. p. 42 (1858).

Lacusa fusco-fusciata, Stàl, Berliu Ent. Zeitschr. vi, p, 309 (1862).
} 
o liack-fuscous: head, thorax, sentellum, rostrum, and tarsi testaceous-whitish, frons and scutellum infuscate: tegmina and wings vitreous; three bands on the tegmina, the posterior two oppositely oblique and united at the commissure, confluent spots on the apex, small transverse lines on the costal limbus and dots sprinkled over the dise, blackfuscous; wings internally and at the apex broally fuscescent; feet sparingly spriukled pallid (Slål). Body long, $5 \frac{1}{2}$; exp. teg., $16 \frac{1}{2}$ millims.

Reported from India.

\section{$\checkmark$ Gemus Corethrura, Hope.}

Trans. Linn. Soc. xix, p. 135 (1845); Stål, Hem. Afric. iv, p. 200 (1866).

Body short, stont: the apex of the alodomen furnished with a rery large and well-marked floceose appendage : lical earinate in front: fac:o seen in front narrow: rostrum of median lenghh: clypens lange, inflited: antenno inserted beneath the eyes, very short, setose to somo length at the apex : ocelli minute placed a little before the eyes: first pair of feot with depressed tibiæ, last tibir externally tridentate (Ilope).

\section{Coretilrura fuscovaria, Hope.}

Corethrura fusco-varin, Hope, Trans. Linn. Soc. xix, p. 135, t. 12, f. 60 (1815); Walker, List Iom. B. M. ii, p. 395 (1851).

Body above somewhat fuscous; head with a whitish transverse line, three rows of white spots on the thorax : abdomen fuscons-green, extremity provided with a subochraceous cottony appendage longer than the entire body: tegmina varied with fuscous, having numerous interrupted bands of a more saturated colour and patches of a farinose powdery substance: wings paler brownish, hyaline, immaculate (IIope). Body long, 19 ; exp. teg., 58-59 millims.

Reported from Silhat.

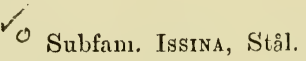

$\checkmark$ Issilla, Stål, Hem. Afrio. iv, pp. 130, $202:^{`}$ Issinc, Ofvor's. K. V.-A. Förh. p. $7 j 4$ (1870).

Head not or only a little narrower than the thorax; clypens very often convex, lateral margins very rarely furnished with a ridge ; thorax truncated at the base, rarely broadly roundly-sinuated, withont a median ridge or only an obsolete one; scutellum short, rarely twice longer than the thorax : tegmina coriaceous or snbcomeous, rarely vitreous, very rarely flat, more or less conve $x_{6}$ sometimes very much abbreviated : clavns and claval vein generally as in Achilina : first joint of last tarsi short or moilorate very rarely elongate. Differs from Ricaniina in the thorax being 
truneaterl or slightly sinuated at the base, scutellnm short never more than twice as long as the thorax; tegmina very ample, very often conrexish, not or but little extending beyoud the abdomen (Stail).

\section{O Genns Henisphærius, Seliaum.} (1866).

Allg. Enc. Wissensch. Kunst. i, p. 51, (1850): Stål, IIom. Afric. iv, p. 203

Last joint of rostrum longer than siont, oval, oblong or elongate : tegmina entirely eonvex, very obsoletely veined or without veins, elavus aud corium comute, no elaval suture: body depressed; vertex narrower than the eyes or subequal in breadth; thorax truneated at the base, sinuated behind the eyes, sides behind the eyes hardly visible from above; last tibia bispinose: anterior femora simple (Stål). This beantiful genus has the entire tegmina quito eoriaceous like thoso of tho lady-bird beetles.

\section{Hemispil erius rufovarius, Walkor.}

Hemispherius rufoutarius, Walkor, List Hom. B. M. Snppt. p. 95 (1858); Butler, A. M. N. 11. (5 sér.) xvi, p. 96 (1875).

Testaceons: vertex transverse with a red mark on the disc, frons and face flat; frons with a red dise, face black, lanceolate : pronotum with three minute red marks: mesonotum with a red stripe on each side: abdomen with a black band beneath : tegmina rather narrower and more oblong than in the other species of the genus (Walker). Body long, $3 \frac{1}{2}$; tege., $8 \frac{1}{2}$ millims.

Reportud from Burma.

\section{Genus Flavina, Stål.}

Ufvors. K. V.-A. Förh. xviii, p. 209 (1861) ; Ilom. Afrio. iv, p. 206 (1866).

IVings eleft, fairly ample, irregularly reticulated; head distinctly narrower than tho thorax, vertex subquadrate; frons slightly ronnded a little abovo the clypens on both sides, longer than broad; elypens ecarinato; thorax truncated at the base, angulated anteriorly behind tho vertex; sentellum somewhat longer than the thorax, tegmina extending somewhat beyond the abdomen, the costa and the commissure subparallel, gradually roundly-narrowed at the apex; the prineipal exterior vein near the base, the median vein towards the apex and interior vein before tho middle, forked, the two last united before the middle by a more distinet transverse veinlet, the interior branch of the fork of that vein also forked: last tibiæ 5-spinose (Stål). 
58. Flatina arandlata, Stál.

$\checkmark$ Flavina granulata, Stål, Ofvers. K. V.-A. Förh. xviii, p. 212 (1861).

․ Weakly yellow-testaceous; tegmina sparingly sprinkled fuscons, extreme part of angles of vertex and basal angles of frons, fuscous ; frons scarcely twice as long as its median breadth, furnished with a median ridge obliterated near the clypeus and a small subbasal, transverse, angulated ridge; thorax granulate; scutellum unicarinate; anterior tibin with two broadly, weakly fuscous rings (Stål). Long with teg., 8 millims.

Reported from India.

Genus Eupilis, Walker.

J. Linn. Soc. Zool. i, p. 93 (1856) ; Stål, Iom. Afrio. iv, p. 207 (1866); Berlin Ent. Zeitschr. x, p. 393 (1866) ; Ofvers. K. V.-A. Förh., p. 760 (1870).

Body very oblong: clypeus transversely convex before the middle, not compressly elevated : tegmina membranons, vitreous, very oblong, scarcely gradually amplified towards the apex, obtusely rounded at the apex; exterior branch of the radial vein running out at the costa or sending out a short branch to the costa; claval veins united almost in the middle of the clavus; wings emarginate at the apex, with two veins running towards the apical incisure united towards the apex : last tibiro bispinose behind the middle (Stal).

\section{$\checkmark$ 59. Eupilis albilingola, Walker.}

Eupilis albilineola, Walker, J. Linn. Soc. Zool. i, p. 93 (1856) ; p. 162 (1857).

. Testaceous, partly pale-green : frons black, shining, with a tawny central spot and with a testaceous border: face with two black bands, the anterior one macular : thorax and pectus with black spots : abdomen with black bands: tegmina and wings transparent, veins black; the tegmina slightly lurid with five brown streaks; transverse veinlets, white (Walker). Body long $8 \frac{1}{4}$; teg., 25 millims.

Reported from Singapore.

\section{Genus Tempsa, Stål.}

Hem. Afric. iv, p. 208 (1866); Ofvers. K. V.-A. Förl. p. 761 (1870).

Body oblong, somewhat cylindrical: head and thorax somewhat equal in breadth, the former obtuse : vertex subequal in breadth to the eyes, truncated, transverse, not produced before the eyes ; clypeus transversely convex before the middle, not compressly elevated, sicles without a ridgo: frons somewhat longer than broad, narrowed upwards, with a longitudinal ridge: thorax anteriorly angulated, truncated at the base; 36 
scutellum longer by more than half than the thorax: tegmina oblong somewhat narrowed towards the apex, obliquely truncated at the apex; coriaceous, somewhat opaque or slightly pellueid; interior ulnar vein simple or forked at a greater distance from the base than the exterior ulnar vein; exterior branch of the radial vein continued towards tho apex of the corium, emitting no branch to the costa ; claval veins united behind the middle of the clavus; wings broad, with two veins running towards the apical incisure united towards the apex : last tibir bispinoso behind tho middle (Stål).

\section{$\because 060$. Tempsa malata, Stål.}

ᄂ Issus malayus, Stål, Ofvers. K. V.-A. Förh., p. 246 (1854).

$\checkmark O$ Eupilis malaya, Stål, Freg. Eng. Resa Ins., p. 277 (1858).

Tempsa malaya, Stål, Berlin Ent. Zeitschr. x, p. 393 (1866).

ð. Elongate, sordid flavescent, obseurely spotted : frons tricarinate the median ridge distinet, continued through, the lateral ridges obsolete, two spots in the middle and four spots on the scutellum, black-fuscous: tegmina elongate, subparallel, longer than the abdomen, somewhat ferruginous, costal margin of a weaker colour. Head sordid flavescent, obscurely spotted, at the apex before the eyes a little truncately produced, vertex quadrate, with a transverse somewhat arched ridge at the apex; frons one-third narrower than its length, very broad towards the apex, gradually somewlat narrowed towards the base, tricarinate, the median ridge continued through, distinct, the lateral ridge obsolete, converging much towards the base, confluent at the base, in the middle on both sides at the median ridge, fuscous: thorax as long as the vertex, triangularly produced, fuscous-flavescent, somewhat impressed lengthwise: scutellum seareely twice as long as the thorax, obsoletely tricarinate, sordid flavescent, witl four small fuscous spots: tegmina extending beyond the abdomen, thrice as long as the median breadth, gradually a little amplified from the base, thence scarcely gradually amplified, obliquely subtruneate at the apex, with longitudinal veins, veins robust, remotely united by other less distinct transverse veins; with a ferruginous tinge, costal margin weak testaceous-flavescent, sublyyaline: wings sordid hyaline with fuscous veins, as long as the tegmina: beneath with feet, weak sordid flavescent (Stål). Long with teg., 9 ; broad, $3 \frac{1}{2}$ millims.

Reported from Malacea, Singapore.

$$
\text { Genus Terrica, Stål. }
$$

Hom. Afric. iv, p. 208 (1866).

Body oval or suboblong: frons subtruncate at the apex, narrowed upwards, unicarinate ; last joint of rostrum oblong or subelongate ; thorax 
and sentellum together, transverse, the former truneated at the base, anteriorly obtusely angnlated, the latter about twice longer than the thorax : tegmina slightly narrowed behind the middle, at the apex very obtusely rounded; corium a little longer than the clavus; rarlial vein of tegmina forked at the base, ulnar veins forked in the middle or a littlo before the middle: wings very broad, deeply emarginate at the apex: last tibire bispinose : first joint of last tarsi rather short. Head and thorax equally broad, the former not prominulous before the eyes, vertex transverse, subequal in breadth to the eyes; frons equally long and broad, amplified near the apex : sides of clypeus furnished with a ridgo : body a little compressed (Stål). Type, T. fusca, Stål.

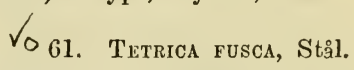

Tetrica fusca, Stål, Ofvers. K. V.-A. Förl. p. 757 , note, (1570).

§. Fuscous, subcompressed, feet pallescent: corium and clavus obsoletely sprinkled pale on the dise : vertex twice broader than long: frons nearly equally long and towards the apex broad, furnished with a single, distinet, obtuse ridge running through it, continued through the clypeus : tegmina somewhat broadish, gradually a little amplified from the base scarcely to the middle, thenee distinctly narrowed (Stal). Long with teg., $5 \frac{1}{2}$ millims.

Reported from Burma.

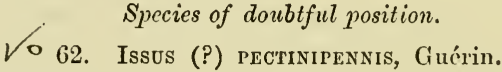

Issus pectinipennis, Gnérin, Voy. Bélanger Ind. Orient. p. 475 (183ł); Spin., A. S. E. F. viii, p. 317 (1839) : Walker, List Hom. B. M. ii, p. 362 (1851).

Luteous spotted with black: head transverse, anteriorly trispinose, one obtuse point in front of each eye and oue forming a prolongation of the frons : tegmina anteriorly dilated, luteous or ochiaceous-yellow, with some small tubercles and short transverse streaks, black; wings brumneous : body beneath yellow, variegated with black; feet flareseent. The anterior margin of the tegmina is spinose; it comprises a limbus ontside the radius as broad as the external flap of the wing, about half a line, transparent, vitriform, or like an exceedingly fine plate of talc, furnished throughout with oblique reins (parallel to each other) contrasting in colour and substance with that of the limbus itself. These veins when the limbus is injured stand out like the teeth of a comb and give a peciliar appearance to the insect. The frons is ascending and is divided from the base to the upper margin into three facettes which form between them obtuse angles; the median increases from below upwards and reaches the rertex and is divided by a longitudinal ridge which descends from above 
and loses itself towards the milllle of the frons; the two interior facettes rise a little higher than the median but without converging above it; they bend vutwards and end in an acute and prominent point above the eyes. The vertex is broader than long, concave, margins gently raised, anterior bisinuate, posterior weakly emarginate. Median lobe of pronotum broad, rounded. Long, 10 ; exp. teg., 23 millims.

Reported from Bengal.

\section{Issus (?) Testudinarius, Stål.}

Issus testudinarius, Stål, Ofvers. K. V.-A. Förh., p. 246 (1854).

Obsemely ferruginons: frons with a longitudinal ridge in the midillo and a transverse one at the base : tegmina coriaceous, longitudinal veins elevated: beneath and feet jellow-testaceous : entire anterior femora and last pair at the apex, fuscescent : abdomen, fuscous in the middle (Stål). Long, 8 ; broal, 6 millims.

Reported from Penang.

\section{¿o Genus Crnene, Westwood.}

Arc. Lnt. ii, p. 35 (1813).

Body short, stout, abdomen compressed: head with frons conical, long, porrect, acute at the apex, carinate above at the sides, ridges obliterated before the apex, posteriorly extended to the pronotum : eyes large, lateral, enarginate beneath : no ocelli : antenno small, inserted below the eyes : pronotum as long as the mesonotum, disc impressed in the middle with two points : tegmina coriaceous, opaque, lomogeneons, convex, broad; anterior margin sinuate, rounded at the apex, posterior angle, acute; veins little branched: feet short, robust, last tibir curved, armed inwards towards the apex with three spines: abdomen trumeated at the apex, ending in two lohes, furnished with a slender, ereet appendage, concave at the apex (IVestwooul). The entire surface of the tegmina is covered with an immense number of minute, circular, elevated areas, visible only under the lens and which give it a shagreened appearance: when at.rest the tegmina are carried almost perpendicularly.

\section{O 64. Crrene fusiformis, Walker.}

Cyrene fusiformis, Walker, List Hom. B. M. Suppt. p. 47 (1858).

o Chalepus aconophoroides, Walker, l. c. p. 192 (1858).

$\delta$,. . Testaceons: heal produced in a lanceolate horn which is straight, hardly asecuding, a little longer than the thorax and has three slight ridges alowe and bencath : logmina very conves in front, straight 
along the interior border, very acute at the tips, with several indistinct, ramified brown marks, veins few : wings vitreous, tinged with grey, a testaceous tinge towards the base; veins fow, pale (Waller). Body long $10 \frac{1}{2}-12 \frac{1}{2}$; teg. 19-23 millims.

Reported from N. China, India : the Indian Museum has a specimen from Sikkim.

$\checkmark$ 65. Cyrene westwoodi, Signoret. (1862).

Cyrene westwoodi, Signoret, A. S. E. F. (4 sér.) ii, p. 12t, t. 1, f. 5, A. B. C.

Brown yellow : a whitish-yellow line extends from the tip of the head to the end of the tegmina which have several dots of the same colour on the disc and are granulate through the whole length so as to have the appearance of being shagreened : head once and half longer than broad, including the eyes, black at the extremity and with a whitish yellow median band, a little elevated; sides carinate: frons coneave at the base and grooved, quadricarinate towards its upper third; the two median ridges reaching the extremity of the head; whereas the two lateral ridges proceed obliquely upwards, contour the head and lose themselves in the lateral ridges of the vertex towards its upper third : rostrum short not extending beyond the posterior coxæ: eyes not emarginate, oval. Pronotum thrice broader than long, rugose, especially towards the anterior and posterior borders with an elevated whitish yellow band and on each side a sunken spot; posterior margin truncated straightly, anterior convex with a strong emargination below the eyes : mesonotum triangular and remarkable for a ridge or rather transverse fold near the anterior margin and very distinct from it this fold appears a little below the latter and extends from one humeral angle to the other and also a little below. Tegmina concave, shell-shaped, with the posterior angle acute, the anterior margin convex, rounded, a little concave on reaching the posterior angle, posterior or sutural margin straight and whitish, the entire surface shagreened; veins numerous and branched towards the tip, several whitish dots on the disc: wings transparent lyyaline: abdomen reddish jellow, compressed : feet brown-yellowish; posterior femora with two lateral spines towards the extremity (Sign.). Body long, 14; teg. extended, 22 millims.

Reported from Cochin-China, Burma (?).

O Subfam. Ricanirina, Stäl.

$\checkmark$ G Ricaniida, Stâl, Hem. Afric. iv, p. 131, 219 (1866); Ricaniina, Ofvers. K. V.A. Förl., p. 765 (1870).

40 
Head broad or very broad, sometimes somewhat narrower than the thorax; sides of clypeus very of ten without a ridge; thorax posteriorly roundly sinuated, without ridges or furnislied only with an obsolete median ridge: scutellum very large, long: tegmina flat, ample or very ample, costa dilated; costal membrane transversely veined or reticulated: last tibio spinose ; first joint of last tarsi short or shortish. Differs from D Tropiduchina in having the thorax without discoidal ridges or only with a single rather obsolete one and the first joint of the last tarsi being short or shortish (Stail).

\section{$\checkmark$ Genus Ricınia, Germar, Stål.}

Mrag. Ent, iii, p. 221 (1818); Stål, Hem. Afrie. iv, p. 221 (1866) : Fieber, Rev. Mag. Zool. (3 sér.) ii, p. 312 (1875).

Germar formed this genus from Flata, Fabr., taking the Indian species $R$. hyalina, Fabr., as his type with the following description:'Head short, transverse : frons lower, subovate, margined on the sides : clypeus annexed to the apex of the frons, conical, subulate at the apex: labrum concealed; rostrum shorter than half the body: eyes globose, pedunculate above : ocelli inserted on the lower margins of the eyes: antenne distant from the eyes, short, first joint minute, cylindrical, secoud short, thicker at the apex, obliquely truncated, setigerous.' This was subsequently reduced by the creation of several genera which Stål reviews, absorbing some, and making other sections or subgenera.

Stål includes in Ricania his own genus Scolypopa (Berl. Ent. Zeitschr. iii, p. 325, 1859) and gives the following diagnosis of the genus :-

Body very broad, not prominent before the eyes anteriorly truncate or obtusely rounded : vertex very broad, short; frons transverse or equally long and broad, very often keeled; sides of clypeus without a ridge : thorax slightly arehed, very often furnished with a fine ridge in the middle: scutellum furnished with three ridges running through it and anteriorly on both sides with an abbreviated ridge : tegmina varying in form and size, very often triangular and very ample; basal tegula large or somewhat largish; two veins emitted from the base of the clavus united in the middle or behind the middle of the clavus : wings moderate or small, anal area furnished with a simple vein : feet moderate, simple; last tibiæ very often bispinose, very rarely trispinose.

$\checkmark$ The principal divisions or subgenera are :-

1. Pochazia, Am. and Serv. Hist. Nat. Ins. Hém. p. 528 (1843); which includes $R$. fasciata, Fabr., and various African and Indian species. $\checkmark \circ$ 3. Tarundia, Stål, Berlin Ent. Zeitschr. iii, p. 325 (1859) and Rio Jan. Hem. ii, p. 70 (1862); which includes several species from Africa and the Indian Archipelago. 
3. Represented by $R$. quinquefasciata, Stål, from Africa.

4. Drulvia, Stål, formerly represented by African species.

5. Deraulax, Signoret, A. S. E. F. (3 sér.) viii, p. 191 (1860) ; $\checkmark$ type D. versicolor, Sign. [l. c.], from Madagascar,

$\checkmark$ 6. Pocharica, Signoret, l. c., p. 192 (1860); type, P. ocellata, Sign., [l. c., p. 192 (1860)], from Madagascar.

- $\checkmark$ ก 7. Pochazoides, Signoret, l. c., p. 193 (1860) ; typo, ${ }^{\circ}$ P. maculatus, Sign. [l. c., p. 193 (1860)], from Madagascar.

$\checkmark$ 8. Privesa, Stål, Rio Jan. Hem. ii. p. 70 (1862) ; ${ }^{\circ}$ type, R. lavifrons

Stål [Stettin Ent. Zeit. xxii, p. 151 (1861)], from Mozambiquo.

Out of the eight subgenera, the Indian species, hitherto recorded, fall under the first two and principally under the first, Pochazia.

\section{o 66 . Ricania hyalina, Fabricius.}

Cercopis fenestrata, Fabricius, Syst. Ent. p. 688 (1775); Stoll, Cig. p. 75, t. 19, e. 102 (1788).

○ Cicada hyalina, Fabr., Syst. Ent. App. 832 (1775); Speo. Ins. ii, p. 326 (1781);

Mant. 1ns. ii, p. 272 (1787); Ent. Syst. iv, p. 40 (179.1).

$\checkmark$ O Flata hyalina, Fabr. Syst. Rhyng. p. 51 (1803).

Ricania hyalina, Germar, Mag. Ent. iii, p. 224 (1818), Burm., Handb. Ent. ii (i) p. 161 (1835).

$\checkmark$ Flatoides hyalina, Walker, List Hom. B. M. ii, p. 404 (1851).

$\checkmark$ Flatoides orientis, Walker, 1. c., p. 417 (1851).

$\checkmark$ Ricania fenestrata, Stål, Ofvers. K. V.-A. Förh. p. 489 (1862) ; Hem. Fabr. ii, p. 105 (1869).

Body small, entirely ferruginous-fuscous : tegmina broad of the same colour, with an abbreviated, broad, hyaline band in the middle, behind the band two small hyaline spots and the posterior margin, interrupted in the middle, hyaline : wings fuscous, immaculate ( $F a b r$.).

Fabricius (in Spec. Ins. 1. c.) abandons the name 'fenestrata' first given by him to this species which was evidently based on an error both of description and in the locality ( $\mathrm{S}$. America) assigned to the species. The rectification of the author should be accepted, especially as ho gives the name' 'fenestrata' subsequently (Syst. Rhyng. p. 51) to a different specios. This is Germar's type of the genus. Long, $5 \frac{1}{4}$; teg., $16 \frac{1}{4}$ millims?

Reported from Ceylon, India; the Indian Museum possess a specimon from Calcutta (?).

\section{ᄂ 67. Ricania fenestrata, Fabricius.}

$\checkmark$ Flata fenestrata, Fabr., Syst. Rhyng. p. 51 (1803).

$\checkmark$ Flatoides fenestrata, Walker, List Hom. B. M. ii, p. 404 (1851).

Ricania Fabricii, Stäl, Hem. Fabr. ii, p. 104 (1868). 42 
Stature entirely of $R$. hyalina, Fabr., but smallor : body black: tegnina fuscous, hyaline at the base, spot on the anterior margin and punctures, fuscous; in the middle a broad oblique hyaline band and numerous spots, hyaline: entire wings obscure' hyaline (Fabr.). Allied to - R. mellerborgi, Stål.

Reported from Java.

\section{Rrcania mellerborai, Stål.}

Ricania mellerborgi, Stål, Ofvers. K. V.-A. Förh. xi, p. 247 (1854).

O Flatoides discalis, Walker, J. Linn. Soo. Zool, i, p. 89 (1856) ; p. 156 (1857).

Testaceous : tegmina fuscous with a large transverse patch and spots on the margin, whitish-hyaline. Allied to ${ }^{\circ} R$. fenestrata, Fabr. Long., 5 ; exp. teg., 16 millims.

Reported from Java, Borneo, Singapore, Burma.

Walker's $\vee$. discalis, is black : frons much broader than long, with a slightly elevated margin and slightly tricarinate: posterior margins of segments of abdomen and the legs dull testaceous : tegmina blackish, with a testaceous dot on the tip of each vein; disc limpid; two limpid dots on the costa and two towards the tip of the exterior border: wings limpid with brown borders. Body long, $6 \frac{1}{4}$; teg., $16 \frac{3}{4}$ millims.

\subsection{9 . Ricania obscura, Fabricius.}

Flata obscura, Fabricius, Syst. Rhyng. p. 49 (1803); Germar in Thon's Archiv. ii (2) p. 49 (1830) : Walker, J. Linn. Soc. Zool, i, p. 92 (1856) ; p. 161 (1857).

v Pochazia obscura (?) Walker, List Hom. B. M. ii, p. 426 (1851).

Ricania olscura, Stål, Hem. Fabr. ii, p. 104 (1869).

q. Pale testaceous-flavescent, vertex and thorax fuscous-testaceons, scutellum black : tegmina ferruginous-fuscous, spriukled pale before the middle and in the middle, and with small palo transverse lines, an unequal narrow band placed behind the middle and the costal membrane obscurely fuscous, the extreme part of its margin pallid, a small oblique transverse line, behind the middle of the costal margin, whitish: wings fuscescent, apical margin of the two last ventral segments black towards the sides. Frons about one-third shorter than broad, gradually roundly narrowed towards the apex, distinctly tricarinate : scutellum 5-carinate, lateral ridges oblique: tegmina triangular; claval suture and apical margin equally long, the latter very slightly subrotundate; costal margin, gradually slightly rounded; apical commissural angle somewhat obtusish, distinct; apical costal angle somewhat rounded; longitndinal veins rather numerous, transverse discoidal veins rare; the posterior transverse voins arranged in two rows, the anterior irregular, the pos- 
terior regular and continued; the interior ulnar vein emitting many branches outwards (Stal). Body long, $5 \frac{1}{2}$; exp. teg., 15 millims.

Reported from Amboina, Borneo, Singapore, India.

$\checkmark=70$. Ricania fuscata, Fabricius.

$\checkmark$ Cicada fuscata, Fabricius, Ent. Syst. iv, p. 28 (1794).

- Flata fuscata, Fabr., Ent. Syst. Suppt., p. 518 (1798); Syst. Rhyng., p. 47 (1803).

$\checkmark$ Ricania obscura, Guérin, Voy. Bélanger Ind. Orient. Zool., p. 466 (1834).

2. Euryptera obscura, Gnérin, 1. c. Atlas, t. 3, f. 6 (1834).

- Pochazia obscura, Stål, Ofvers. K. V.-A. Förh., p. 160 (1865); Walker, List Hom. B. M. ii, p. 426 (1851).

$\checkmark$ Paciloptera antica, Westwood, Griffith's An. King. Ins. ii, p. 260, t. 90, f. 4; t. 138, f. 4 (1832).

$\checkmark \bigcirc$ Pochazia fumata (?) pt., Walker, 1. c. p. 426 (1851).

Ricania fuscata, Stål, Hem. Fabr. ii, p. 104 (1879).

Head fuscous, frons flat, margin and median line clevated: thorax dull black, a dorsal and smaller incurved lateral line, elevated : abdomen fuscous : tegmina and wings deflexed, truncated, hyaline-black, immaculate: feet fuscous ( $F a b r$.).

Dark brown with a small spot near the middle of the anterior margin ; the lower wings are eovered with a bluish powder at the base: apparently belongs to Euryptera, Guérin (Gray in Griffith, $l$. c.).

Obscure, somewhat cœrulean, covered with a powdery substance; thorax tricarinate: tegmina triangular, anterior margin somewhat straight, wings concolorous; feet abbreviated, brunneous-ferruginous (Guérin). Long 9 : exp. teg. 30 millims. Stål identified this from the type with his own $P$. obscura which in Hem. Fabr. (l. c.) he makes one with $R$. fuscata, Fabr.

$\sigma^{7}$. Blackish; abdomen and feet pale fuscous-testaceous : tegmina and wings obscurely fuscous, the former marked behind the middle of the costal margin with a small, more or less distinct, flavescent greyish spot; costal and apical margins not sinuated towards the apical costal angle: wings behind the middle with the veinlets irregularly arranged and furnished towards the apex with a row of veinlets ; frons very transverse, very roundly narrowed towards the apex, furnished with a median longitudinal ridge (Stål). Body long, 7-8; exp. teg., 29-32 millims.

Reported from Tranquebar, Java, Cambodia, Burma: the Indian Museum possesses a specimen from $\mathrm{N}$. India.

71. Ricania fumata, Am. \& Serv.

$\checkmark$ ○ Pochazia fumata, Am. \& Serv., Hist. Nat. Ins. Hém. p. 529 (1843); Walker, List Hom. B. M. ii, p. 426 (1851), excl. syn.; J. Linn. Soo. Zool. i, p. 91 (1856) p 160 (1857) and x, p. 163 (1867) : Stål, Berlin Ent. Zeitschr. vi, p. 314 (1862). 
In all respects similar to $R$. fasciata, Fabr., but without a liyaline band or spot. Black-fuscous, beneath with feet and vertex sordid yellow-livid; tegmina and wings fuscous-pellucid, in certain positions shining subviolaceons; small marginal space on the tegmina at the costal sinus obsoletely pallescent. Frons almost half broader than the length, lateral margins slightly converging at the base, gradually rounded beneath the middle towards the apex, tricarinate, the median ridge somewhat continued throngh, the two lateral more obsolete, continued from the base scarcely to the middle: the apical margin of the tegmina somewliat longer than the commissural margin, very slightly sinuate between the middle and the apical angle, costal margin broadly distinctly sinuate a little behind the middle: wings furnished posteriorly with transverse veinlets arranged in two rows, the posterior row more regular: last tibir armed with two distinct spines behind the middle and before the middle (always?) with a small spinule (Stål). Exp. teg., 41 millims.

Reported from Java, Sumatra, Borneo, Malacca, Singapore, Tenasserim.

\section{Ricania ainuata, Stål.}

(2) Pochazia sinuata, Stål, Ofrors. K. V.-A. Förh. p. 160 (1865).

- Pochazia fasciata, Am. \& Serv. [nec Fabr.], Hist. Nat. Ins. Hém. p. 628, t. 9, f. 7 (1843) : Walker, List Hom. B. M. ii, p. 426 (1851) ; J. Linn. Soc. Zool. i, p. 91 (1856).

ð. Blackish ; beneath with feet fuscous-testaceous ; tibiæ and tarsi, paler; tegmina and wings black-fuscous, the former slightly shining violaceous; a band on the tegmina placed behind the middle abbreviated near the costal margin and sometimes interrupted, and a median band on the wings abbreviated towards the anal area, whitish. Stature entirely of $R$. fumata, A. \& S.: the frons with obsolete longitudinal strie and three obsolete ridges: wings behind the middle with two abbreviated transverse rows of transverse veinlets; costal apical angle of tegmina a little more produced than in $R$. fumata (Stål). This species is often confounded with $R$. fasciata, Fabr., which is somewhat like in the marking, but differs in having the costal and apical margins of the tegmina straight and not sinuated, the exterior apical angle less produced and the head somewhat narrower, and is moreover an African species. Long, 81 ; exp. teg., 35 millims.

Reported from Singapore, Malacca.

73. Ricania speculdu, Walker.

2. Flatoides speculum, Walker, List Hom. B. M. ii, p. 406 (1851).

¿ Flatoides tenebrusus, Walker, l. c. p. 406 (1851): J. Linn. Soc. Zool. i, p. 89 (1856). 
$\checkmark$ Flatoides perforatus, Walker, l. c. p. 407 (1851): J. Linn. Soc. Zool. x, p. 147 (1867).

$\checkmark O$ Ricania malaya, Stål, Ofvers. K. V.-A. Förh. p. 247 (1854).

Ricania speculum, Stål, l. c. pp. 489, 491 (1862).

ㅇ. Body black : legs ferruginous : tegmina brown with five colourless or whitish-hyaline spots, two on the disc, one near them on the costal margin, and two on the apical margin, of which the one nearer the posterior angle is sometimes interrupted so as to appear two, veins brown, whitish on the colourless parts : wings paler brown, pellucid, with many almost colourless dots. Body long, $6-8 \frac{1}{2}$; teg., $21-24$ millins.

Reported from Philippines, China, Malacca, Singapore: the Indian Museum possesses a series from Pankabári, Sikkim, Sibságar (Assam).

\section{$\checkmark$ 74. Ricania fumosa, Walker.}

$\checkmark{ }^{B}$ Flatoides fumosa, Walkcr, List Hom. B. M. ii, p. 414 (1851). Ricania fumosa, Stâl, Ofvers. K. V.-A. Förh. p. 491 (1862).

६. Body dark ferruginous; frons and legs ferruginous : mesonotum piccous : tegmina blackish brown, veins black : wings brown. Body long, $3 \frac{1}{4}$; teg., $12 \frac{1}{2}$ millims.

Locality not reported: the Indian Museum possesses a specimen from Assam?

\section{75. Ricania apicalis, Walker.}

\section{$\checkmark$ Dochazia apicalis, Walker, List Hom. B. M. ii, p. 431 (1851). \\ Ricania apicalis, Stảl, Ofvers. K. V.-A. Förh. p. 491 (1852).}

q. Body testaceous : mesonotum black : legs testaceous : tegmina dull fawn-colour, ample, finely pubescent, with two indistinct pale brown oblique bands, the first forming a ringlet; a black dot by the tip of the fore-border, veins tawny: wings pale grey, pale brown along the hind border. Body long, $5 \frac{1}{4}$; teg., $16 \frac{1}{2}$ millims.

Locality not reported: the Indian Museum possesses specimens fairly agreeing with the description from Sikkim.

\section{$\checkmark$ G 76. Ricania OCELLUS, Walker.}

$\int{ }^{0}$ Pochazia ocellus, Walker, List Hom. B. M. ii, p. 429 (1851).

$\sqrt{ }$ Flatoides facialis, Walker, 1. c. Suppt. p. 100 (1858).

Ricania ocellus, Stål, Ofvers. K. V.-A. Förh. p. 491 (1862).

8, ․ Borly piceous: vertex and frons with a ferruginons rim: clypeus and rostrum tawny: abdomen ferruginous at the base and be- 
neath: legs tawny : tegmina and wings colonrless with brown borters, the former ample, a brown dot near the base, beyond it two slender brown bands; the first forming a brown ringlet on the disc between which and the border it is widenerl and includes a colourless dot; tho second very slight extending along the outer band of transverse veins; veins tawny, liere and there brown: stigma tawny: wings with a brown exterior border. Borly longr, 5-6 $\frac{1}{2}$; tog., 17-19 millims.

Reported from China: tho Indian Museum las a specimen from Assam.

\section{$\checkmark$ o 77. Ricania interrupta, Walker.}

$\checkmark$ Pochazia internuta, Walkor, List Hom. B. M. ii, p. 428 (1851): neo P. inter. rupta, J. L. S. Zool. i, p. 91 (1856).

Ricunia interruptu, Stål, Ofvors. K. V.-A. Förh. p. 491 (1862).

․ Boity black: heal very short, as broad as tho thorax; vertox very short, dark ferrugrinous, bordered by a rim, sinuate on tho posterior border, nearly straight in front, its length in the middle abont lialf of that on each sicle; frous very finely striated, rounded on each sido, rather narrower towards tho clypeus, bordered by a ferruginons rim, slightly concave where it joins the clypous, tricarinate, the lateral ridges indistinct, its brealth a little less than twice its length; clypeus ferruginous, triangular, with a slight median ridgo; pronotum very slightly sinuated behind, rounded anteriorly with a median ridge, on each side of which thero is an impression, its length in the middlo less than twice that on each side: mesonotum vory finely striated, 5 . carinate, the two ridges on each side united on the disc : abdomen dark ferruginous, olsconical, a littlo longer than the thorax : legs ferruginous : tegmina lark brown, ample, triangular, with a broad, oblique whito baud which is interrupted in front; a row of white dots oxtending on the elge of the tegmen from the hind bordor along one-third of tho distance to the tip; veins blackish, pale yellow on the whito parts; longitudinal veins very numerous ; transverse veins few ; fore-border straight, along it a row of mostly parallel transverse veins which are more oblique whero tho longitudinal vein appears contorted, beyond this thoy aro shorter: wings brown, little more than half tho length of the tegmina with a whito band which forms one with that on the tegmina (Walker). Body long, $6 \frac{1}{4}$; teg., 25 millims.

Reported from Malabar.

\section{Ricania simulans, Walker.}

$\checkmark$ O Pochazia simulans, IValker, List Hom. B. M. ii, p. 431 (1851).

Ricania simulans, Stàl, Ofvers. K. V.-A. Förb. p. 491 (1862). 
. Body ferruginous: liead as broal as the thorax; vertex very short, posteriorly sinuate, very slightly rounded in front, shorter in the middle than on each side; frons flat, rounded on each side, narrower towards the clypeus, bordered by a rim, concave where it joins the clypeus, not rilged, its breadth nearly twice its leng th : elypens triangular: pronotum very short, arched, bordered by a rim : mesonotnu black, not ridged : metanotum tawny : abdomen obconical, taw ny at the baso, hardly longer than the thorax: legs tawny: tegmina brown, ample, a tawny triangular spot on the anterior margin beyond the miildle; tivo broad, oblique, very irregular, colourless bands on the disc, first short, second interrupted ; veins tawny, longitu dinal veius numerous, transverse veins few ; anterior margin slightly convex, along it a row of parallel transverse veins which aro contorted and more obligno towards tho t.jp: wings palo greyish-brown (Walker). Body long, $5 \frac{1}{1}$; teg., $16 \frac{1}{2}$ millims.

licported from N. India.

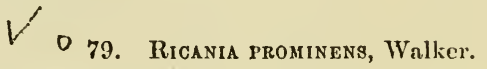

Ricania prominens, Walker, Ins. Saund. Hom. p. 48 (1858).

Dull testaccous: head with eye and antenmo forming a large rertical compartment; vertex transverse, very short, mostly covered by tho pronotum ; frons with transverse blackish marks, very inucli longer than broad, with elevated borders and three slight ridges, tho midllo ono abloreviated, tho pair converging towards the face, where they aro commected; face lanceolate, ridged: pronotum bicuninate, very convex along the fore border; mesonotum with a brown interlined dise and two blackish dots on each side; metanotum and abdomen dark brown, tho latter with a pale testaceous stripe on each side: legs testaccous, femora slightly streaked with black : tegmina with brown marks along the costa and with a few brown marks elsewhere and with an irregular whitish subapical band; stigma whitish; veinlets regular along the costa alid along the exterior border where they are mostly forked, the discal veins and veinlets irregular, the latter numerous; wings with very few veinlets; both vitreous grayish, veins black and tho exterior borders brown (Walker). Body long, $8 \frac{1}{2}$; teg., 25 millims.

Reported from Silhat.

$$
j \circ 80 . \text { Ricania guttifera, WValker. }
$$

'O Pochazia guttifera, Walker, List IIom. B. M. ii, p. 427 (1851).

Ricania guttifera, Stàl, Ofvers. K. V.-A. Förh. p. 491 (1862); Distant, J. A. S. B. xlviii (2), p. 38 (1879). 
$\delta$, ㅇ․ Body black: liead very short, as broad as the thorax: vertex bordered with a rim, sinuate behind, straight in front, its length in the middle about half of that on each side: frous dark ferrngrinous with a black border, very finely striated, rounded on each sicle, narrower towards the elypeus, bordered by a rim, hardly sinuated where it joins tho elypens, liaving a mildle ridgre which does not reach the fore-border, its breadth nearly twiee its length : elypens triangular, with a middle ridge : pronotmu shightly simute behind more rounded on the anterior margin, with a midlle rillye much longer in the middle than on each side; mesonotnm 5-carinate, the two ridges on each side united on the disc : abdomen obeonical, a little longer than the thorax, ferruginons towards tho base: leg's ferruginous: tegmina triangular, ample, dark brown, likckish along the fore-border, with three colourless spots, one on the forc-border beyond the middle, one near the tip and one which is smaller near the lind border: a white dot on the dise and between it and the tip a small indistinet, tawny spot; veins blackish, tawny on the colourless spots, longitudinal veins very numerous towards the tips, transverse veins free; fore-border straight, along it a row of oblique, mostly parallel, transverse veins which are shorter towards the tip: wings dark lrown, little more than half the length of the tegmina (Waller). Body

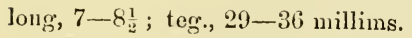

Reported from Silhat (Assam).

\title{
Species doubtfully Indian.
}

\author{
$\checkmark$ V $\checkmark$ 81. Ricania gutwata, Walker. \\ p. 156 (1857). \\ Flatoides guttatus, Walker, List Hom. B. M. ii, p. 408 (1850) : J. L. S. Zool. i, \\ Ricania guttata, Stål, Ofvers. K. V.-A. Förh. p. 491 (1862).
}

§. Black : vertex piceons, frons dark ferruginons: pronotum ferruginous : legs tawny, femora piceous : tegmina blackish-brown, with three whitish-hyaline spots, one on the disc round, second larger and almost triangular placed on the costal margin near the tip, third as large as the first placed on the tip near the costal margin; a row of colomrless dots along the tips of the tegmina; veins blackish, palo on the spots. Body long, $6 \frac{1}{4}$; teg., 21 millims.

Reported from Hong Kong, Borneo.

\section{$\checkmark$ 8:. Ricania episcopus, Walker.}

Flatoiles episcopus, Walker, List Hom. B. M. Suppl. p. 100 (1858).
Ricania episcopus, Stål, Ofvers. K. V.-A. Fórh., p. 491 (1862).

Tawny, testaceous beneath : abdomen luteons: tegmina and wings whitish; the tegnina with three broad blackish bands which are con- 
nected in front, the first and second connected in the middle; the three more or less connected with, or interrupted by three chalybeous black bands, of which the first is costal, the second is curved and contained in the fore-part of the second blackish band, and the third is marginal : a deep black spot half enclosed in the second chalybeous band: the wings with a broad median lurid band and a blackish marginal band. Body long, $8 \frac{1}{2}-9 \frac{1}{2}$; teg., 21-23 millims.

Reported from N. China.

83. Ricania obliqua, Walker.

$\checkmark$ Pochazia obliqua, Walker, List Hom. B. M. ii, p. 429 (1851).

Ricania obliqua, Stål, Ofvers. K. V.-A. Fôrh., 591 (1862).

ð. Body black : frons dark ferruginous : legs ferruginous : tegmina brown, ferruginous towards the base (the costal margin excepted), with two slightly tawny bands, the outer one of irregular breadth, the immer one shorter and broader, and between them on the costal margin is a slightly tawny nearly triangular spot; veins concolorous: tho wings are very slightly tinged with tawny, brown along the fore-borders. Body long, $6-7 \frac{1}{4}$; teg., $19-21$ millims.

\section{$\checkmark \circ$ 84. Ricania marginalis, Walkcr.}

Flatoides marginalis, Walkor, List Hom. B. M. ii, p. 409 (1851) : J. Linn. Soc Zool. i. p. 89 (1856).

Ricania marginalis, Stål, Ofvers. K. V.-A. Förh. p. 491 (1862).

․ Body black; abdomen and legs ferruginous: femora piceons: tegmina and wings blackish-brown, the former with five colourless spots of which one is a dot on the disc, second very large, triangular, on the costal margin near the tip, third much smaller on the tip, with $2-3$ colourless dots, fourth and fifth small irregular, on the tip near the hind border; a row of colourless dots along the tips of the tegmina; veins blackisl, pale on the spots. Body long, $7 \frac{1}{4}$; teg., 25 millims.

Reported from Singapore, Africa (?).

○ 85. Ricania WALKERI.

O Pochazia interrupta (n. b. 1.), Walker, J. Linn. Soc. Zool. i, p. 91 (1856).

Testaceous : tegmina and wings brown, the former partly lurid to. wards the hind border, an interrupted band beyond the micllle, tips hyaline, slightly testaceous. Vertex much broaler than long; frons elongate subquadrate, with a slight groove in the midale: pronotum arched, extending over part of the vertex: mesonotum slightly tricarinate (Walker). Body long, $6 \frac{1}{4}$; teg., $14 \frac{1}{2}$ millims.

Reported from Singapore.

50 


\section{$\checkmark \odot$ 86. Ricania costrmacula, Walkor.}

$\checkmark$ O Pochazia costimacula, Walker, J. Linn. Soo. Zool. i, p. 91 (1856)..

Black : head and legs tawny; vortex brown with a tawny border : tegmina and wings blackish, the former mostly lurid along the borders and about the transverse veinlets and with a whitish hyaline spot on the costa beyond the middlo. Frons broader than long with a median ridge

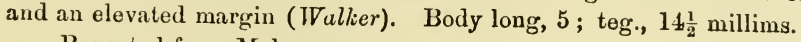

Reported from Malacca.

87. RiCania GRADIENS, Walker.

${ }^{\circ}$ Pochazia gradiens, Walker, J. Linn. Soc. Zool. i, p. 91 (1856).

Tawny, testaceous beneath : tegmina and wings blackish, the former tawny along the costa. Head with a median ridge and with the margins elevated: frons hardly broader than long, the sides rounded (Walker). Body long, 5 ; teg., $12 \frac{1}{2}$ millims.

Reported from Singapore.

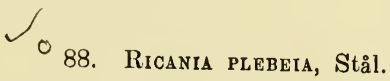

Ricania plebeia, Stål, Ofvers. K. V.-A. Förh. p. 162 (1865).

९. Fuscous-greyish; beneath with frons and fect, paler; tegmina fuscous, sprinkled with minute pale dots before the middle; a small obliquely transverse median line. on the costal limbus whitish, and a very minute punctiform spot on the apical costal angle, black: wings infuscate. Frons tricarinate: commissural apical angle of the tegmina straight, apical margin almost entirely straight (Stå). Long, 7; exp. teg., 22 millims.

Reported from Siam.

\section{Ricania limitaris, Stål.}

Ricania limitaris, Stål, Ofvers. K. V.-A. Förh. p. 161 (1865).

Fuscous-testaceous, frons and feet paler: tegmina fuscous, clavus and indeterminate interior part of the corium, paler; a largish costal spot placed almost behind the middle, sordid whitish; a small shining spot in the costal apical angle, blackish, and a small obsolete discoidal spot, fuscons: wings very slightly infuscate. Frons obsoletely tricarinate, costal limbins of tegmina remotely transversely veined (Stål). Long, 8 ; exp. teg., 22 millims.

Reportod from Cambodia. 
- 90. Ricanta pulverosa, Stal.

Ricania pulcerosa, Stàl, Ofvers. K. V.-A. Förh. p. 162 (186்).

d, \&. Fuscous-testneeous; vertex, thornx, and sentellum, llack: the basal part of the tegmina powdery-flarcseent and the dise clouted fuseous; the transverse discoidal veinlets and the costal margin before the inildle, pale; the latter minutely spotted fuseons; three costal spots, the median somewhat large, a sunall one near the apex, and a very minute apieal one, yellow-whitish; the median eostal spot with black transverse lines; a minute spot in the apical eostal angle, black: wings weak fuscescent. Frons distinetly tricarinate: tegmina densely veined, the transverse veinlets on the costal limbus remote (Stal). Long, 4-7; expl. teg., 1t-20 millins.

Reported from Cambolia.

\section{$\checkmark$ 9l. Ricania efiscopahis, Stal.}

Ricania episcopalis, Stål, Ofvers. K. V.-A. Förh. p. 162 (18๙்̃).

$\$$. Weak fuscous-testacenus: tegmina more obseure, costal spot behiud the middle also two bands, one plinced before the mirlle and abbrevinted outwards, the other placed behind the midlle and abbreviated near the costal margin, somewhat interrupted in the middle and proilncer a little forwards anteriorly, whitish hyaline; a spot near the eostal margin behind the middle and an areh placed botween the spot and the na:yin, black; wings very slightly infuseate, tho base and a transverse spot behind the middle, whitish. Frons with a median obsolete ridge, lateral ridges very obsolete: tegmina densely veined, very numerous transverse veinlets on the costal limbns, several of which are forked (Stål). Long, 7 ; exp. teg., 21 millius.

Reported from N. China, Formosa.

\section{$\checkmark 6$ Genus Mrindura, Stảl.}

Rio Jan. IIom. ii, p. 69 (1862).

In Hem. Afric. iv, p. 220 (1866), Stal unites the genera Mindura

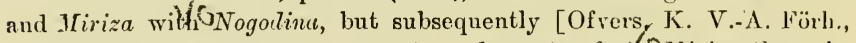
p. $769(1870)]$ keegs them separate and ereates from Miriza the subgenern Vurcia and Sassula, to the latter of which ${ }^{\circ}$ Ir. sorurcula, Stal, belongs.

Frons with two distinet ridges, slightly eonverging towards the apex, much longer than bread; vertex distinetly prominulous before the eyes; lateral margins of the clypens curinate at least at the base: tegmina equally broad, broally rounded at the apex, furmished between the apex of the clarus and the trausversely veined costal area with a continued 
row of distinct transrerse veinlets, the costal area of the usual breadth; interior vein of corium forkerl before the midlle.

A. Tegmina vitreous; the first and second longitudinal veius emitted firm the hasal area not forked before the transverse row of veinlets mentioned above, transverso veins rare, very rare and obsolete before tho row ahove mentioned; transverse veins on tho apical part forming two rows, before which irregularly seattered transverse veins are present; last pair of tibio 3 -spinose.-Mrriza, Stål, of which the type is Ricania bolemani, Stål.

B. 'Tegmina opaque, with somewhat closely arranged transverse veinlets; the second longitudinal vein emitted from the basal area forked before the continued trinsverse row of veinlets; numerous transverse veinlets irregularly arranged on the apical part: last pair of tibio, 4-spinose. - Mindura, Stål, of which the type is Flata obscura, Fabricius.

\section{92 . Miriza sordrcula, Stål.}

Jfiriza sorurcula, Stål, Ofvers. K. V.-A. Förh. p. 164 (1865); p. 769 (1870).

ð. Weak testaccons-flavescent: tegmina and wings sordid hyaline : extreme part of the lateral margins of the frons and clypeus, median riclge on the frous, two spots on the vertex and thorax, three lateral spots on the sentellum, the clavus except the basal part, irregular marginal spots on the corium which are more or less confluent, apical limbus of the wings, lateral margins and abbreviated bands on the dorsum of the abdomen, fuscous: disc of the scutellnm more obscure (Stål). Long, 11 ; exp. teg., 30 millims.

Reported from Cambodia.

\section{1 s 93. Mindura nemerobit, Walker.}

o Ricania hemerobii, Walker, List IIom. B. M. ii, p. 425 (1851) ; J. Linn. Soc. Zool. i, p. 89 (1856).

$\sqrt{ }$ Mindura hemerobii, Stảl, Ofvers. K. V.-A. Förh. p. 491 (1862).

б, ?. Body tawny : frons dotted with brown, bordered by a blackedged rim; elypens with a median ridge and border, black : mesonotum ferruginous witl a tawny median stripe and two oblique black and slightly undulating ridges: abdomen with a black stripe above: legs tawny, striped black : tegmina and wings nearly colourless, the former with the tips and five spots, brown; of the latter two are placed near the tips towards the hind border, one near the tip on the fore-border and two are by the stigma which is tawny; veins black: wings edged with brown. Body long, $8 \frac{1}{2}$; teg., 27 millims.

Reported from Ceylon, Malacca. 


\section{$\checkmark$ Genus Pucina, Stål.}

Hem. Afric. iv, p. 221 (1866), Berlin Ent. Zeitschr. s, p. 393 (1866).

Clavus without transverse veinlets: head not prominent before the eyes; vertex transverse; clypeus convex, without lateral ridges: tegmina gradually slightly amplified towards the apex, furnisheil towards the apex with oblong areolas arranged in two rows and with many areolas less regularly arranged on the disc; ulnar veins and radial forked somewhat before the middle of the corium ; first tibio hardly longer than the femora and trochanters, last tibiæ bi-spinose (Stål).

\section{$\checkmark$ 94. Pucina peluucida, Guérin.}

$\checkmark \diamond$ Cixius pellucidus, Guérin, Voy. La Coquillo, Zool. ii, (2), p. 189 (1830) : Icon. Rigne Animal, t. 58, f. 4 (1830-34).

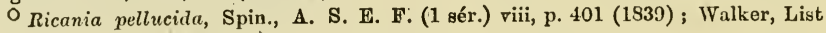
Hom. B. M. ii, p. 423 (1851).

Pucina pellucida, Stål, Berlin Ent. Zeitschr. x, p. 393 (1866).

Head yellowish with three ridges: frons thrice longer than broad, strongly margined and with a median ridge; vertex broader than long, disc flat and horizontal, margins elevated, fine; anterior margin obtusely angular, its tip extended a little beyond the eyes; posterior margin angularly emarginate : thorax varied with green and brown, also the abdomen, which is less high than broad : tegmina and wings transparent, veins brown, with a brown triangular dot on the anterior margin of each tegmen and near its tip; radial vein weakly arcuate, sub-radial straight, rejoining the radial towards the second third on the anterior margin, the intermediate space with eight transverse, sub-parallel veins and divided into nine fairly large cellules, of which the seven intermediate are as broad as long, the two extreme longer than broad; the adjoining space between the radial and cubital veins divided into two large, narrow, elongate cellules by a complete, transverse vein : feet yellowish, tarsi brown; posterior tibiæ with two lateral spines. Long, 6 ; exp. teg., 16 nillims.

Reported from Java, Bengal.

Subfam. Flatins, Stål.

Flatida, Hem. Afric: iv, pp. 131, 235 (1866); Flatina, Ofvers. K. V.-A. Förh. p. $771(1870)$.

Clavus granulate, apex sometimes subacute and closed, sometimes very obtuse and broadly open; with two veins separated through the entire length or near the apex united in.one; costa dilated, costal membrane transversely reined; claval suture distinct; anal area of wings not reticulated: last tibio without a mobile spur (stål). 


\section{${ }^{\circ}$ Genus Cerrania, Stãl.}

Rio Jan. Hem. ii, p. 68 (1862) ; Hem. Afric., p. 235 (1866).

First joint of antennæ oblong or elongate, hardly shorter than the second; genw anteriorly rounded; frons longitudinally convex : thorax prodnced in the middle and covering the short vertex; tegmina very greatly deenmbent, very ample; posterior tibiø very often bi-spinose : costal membrane narrowed at the base (Stål).

\section{$\checkmark$ o 95. Cerrnia maria, White.}

O Paciloptera maria, Whito, A. M. N. H. xviii, p. 25, t. 1, f. 3 (1816).

$\checkmark$ OFlata maria, Walker, List IIom. B. M. ii, p. 436 (1851).

Cerynia maria, Stål, Ofvers. K. V.-A. Förh. p. 490 (1862); Distant, J. A. 8 Ben. xlviii (2), p. 38 (1879); A. M. N. H. (5 sér.) xi, p. 172 (1883).

1 Of a very delieate white colour with a reddish wax-like spot not far from the base of the tegmina, an interrupted somewhat curved narrow black line running across the wing not reaching the fore-margin : behind it, and not far from the end of the inner margin there is a short narrow black line: the tegmina more or less powdered with a waxy seeretion; the wings white, somewhat hyaline: head, thorax, body and femora very pale yellow; antennæ and tibiæ blackish: a large tuft of white, waxy, spongeous matter at the end of the body. In some specimens the red mark on the tegmina is nearly obsolete and the transverse black line is quite obsolete anteriorly (White). Exp. teg., 33-34 millims. $\checkmark \circ$ Var. a. ${ }^{\circ}$ Flata tenella, Walker, l. c. supra, p. 437 (1851), has the tegmina of a very delicate pale-green, abdomen in or concolorous and in $\&$ pale yellow.

$\checkmark$ o Var. b. Cerynia rosea, mili, has the tegmina of a delicate pale rose eolour and comes from Sikkim.

Reported from India, Assam, Tenasserim. The Indian Musenm possesses specimens from Sikkim, Assam, Tenasserim.

\section{$\checkmark$ Genus Phromnia, Stål.}

Rio Jan. Ilem. ii, p. 68 (1862) ; Hem. Afric. iv, pp. 235, 239 (1866) : Flata, pt., Am. \& Serv., Hist. Nat. Ins. Hém. p. 521 (1843).

Body oblong, compressed: head much narrower than the thorax; vertex short, thorax concealed; frons longitudinally convex, seen from the side roundly-prominulous; genæ anteriorly rounded; clypeus long: no ocelli : antennæ elongate, rounded, second joint twice or half longer than first: dise of thorax elevated behind the vertex, the elevated part somewhat sloped forwards, produced, covering the vertex : scutellum 
convex : tegmina very ample, very greatly decumbent, longer by half than broad, rounded at the apex, very densely longitudinally veined, few transverse veinlets on the dise, furnished near the apex with a regular row of transverse veinlets, costal membrane everywhere equally broad; costal area furnished with obliquely transverse, forked, veins : feet moderate, simple; last tibire very often bispinose (Stål).

i) 96. Phromina marginflia, Olivier.

- Fulgora marginella, Olivier, Enc. Méth. vi, pp. 566, 575 (1791): Stoll, p. 50, t. 11, f. 54 (1788).

$\checkmark$ a Flata marginella, Walker, List Hom. B. M. ii, p. 434 (1551) ; excl. syn.

Phromnia marginella, Stål, Ofvers. K. V.-A. Förh. p. 490 (1862); Distant, A. M. N. H. (5 sér.) xi, p. 171 (1883).

Body and feet greenish : apical joints of antenno brown : fermina bright green; at the base itself with an orange-patel (at least in old. specimens) costal margin up to apical fiftl narrowly sanguineous, bordered interiorly with verdigris green, longitudinal veins slightly orange towards the base: wings white, transparent. Bocly long, 13 ; teg. long, 24 millims.

Reported from Coylon, Mergui ; tho Indian Museum las a series from Sikkim, Assam.

\section{O 97. Phromina tricolor, White.}

$\checkmark$ s Pceciloptera (Flatida) tricolor, White, A. M. N. H. xviii, p. 26 (1846).

$\checkmark$ o Flata tricolor, Walker, List Hom. B. Mr. ii, p. 435 (1S51).

Pliromnia tricolor, Stål, Ofvers. K. V.-A. Ë̈rh. p. 490 (1862) : Distant, A. M. N. II. (5 sér.) xi, p. 172 (1883).

Tegmina palc-green, anterior margin (especially at tho base) reddish, the colour gradually verging into green; a few white powdery clots on the basal part, the underside washed whito: wings white, somewliat powdered; veins, especially at the base, greenish : body and legs palegreen. The front edge of the wings near the baso has a prominent angle, followed by a sinuation (White). Exp. teg. about 48 millims.

Reported from Silhat: the Indian Museum possesses specimens from Siam, Samaguting and Naga hills in one of which the green of the tegmina has faded to orange-yellow and in others the red is far advanced towards the middle and in others wanting.

\section{$\checkmark$ o 98. Phromina robicunda, Distant.}

Phromnia rubicunda, Distant, A. M. N. H. (5 sér.) xi, p. 171 (1S83).

Tegmina dull reddish, beconning slightly paler towarls the apex; the basal, marginal and apical areas above somowhat irregularly tinged 56 
and spotted with chalky white; beneath more evenly and palely tinged with the same colour : wings white: body pale ochraceous, the pronotun somewhat darker in hne: legs pale ochraceous, first and intermediato tibio and tarsi, black; last tarsi with the apieal joint, black: tibir strongly suleated, last tarsi armed with three prominent spines. Allied to $P$. tricolor, White, but differs in the longer tegmina and different colour of the same, different colour of tibiw, \&c. (Distant). Exp. teg., 62 millims.

Reported from Mergui.

$$
\checkmark \text {. } 99 \text {. Phrominia intacta, Walker. }
$$

$\checkmark$ Flata intacta, Walker, List Ifom. B. M. ii, p. 435 (1851).

Phromnia intacta, Stål, Ofvers. K. V.-A. Förh. p. 490 (1862).

q. Body pale stramineous : antennæ long, stramineous, third joint black, much longer than the second: pronotum almost truncate-conical on the dise, somewhat impressed in front, tricarinate, ridges produeed through the mesonotum: abdomen obconical, not longer than the thorax : legs tawny; anterior tarsi and tips of the anterior tibiæ and of the hind tarsi, black : tegnina dingy white, veins white: wings milk-white. Body long, $9 \frac{1}{2}$; teg., 46 millims.

Reported from Silhat.

\section{$\checkmark$ o 100 . Pirrominia inornata, Walker.}

- Flata inornata, Walker, List Hom. B. M. ii, p. 438 (1851).

Phromnia inornata, Stål, Ofvers. K. V.-A. Förh. p. 490 (1862):

Body tawny : antennæ black, very long, tawny towards the base : pronotum straight behind, conical in front, its length about one-fourth its breadth; mesonotum indistinetly tricarinate, dise flat: abdomen obconical, a little longer than the thorax : legs tawny, feet and tips of the anterior tibia, black: tegmina dull pale tawny, veins yellow: wings colourless. Body long, $12 \frac{1}{2}$; teg., 42 millims.

Reported from Tenasserim.

$$
\text { Y O Genus Lechêa, Stál. }
$$

Mem. Afrie. iv, p. 236 (1866).

Tegmina furnished towards the apex with one or two rows of transverse veinlets or with veinlets irregularly scattered throughout, and with very many or several longitudinal veins forked at the apex, the longitudinal veins at the apex rarely simple, if so, the tegmina are furnished witlı a single row of veinlets near the apex. Body cylindrical or compressed; tegmina very greatly decumbent. Frons seen from the 
side and genæ prorluced in the middle; tegmina very ample, gradually somewhat amplified towards the apex, furnished near the apex with a regular arched row of transverse veinlets whieh begins behind the apex of the clavns, costal area transversely veined, some veins auastomosed (Stål)! ○ Type, L. dentifrons, Guérin.

\section{Lechea dentifrons, Guérin.}

Peciloptera dentifrons, Gnérin, Icon. Règne Animal, Texte, p. 360 (1830-34). Walker, List IIom. B. M. ii, p. 445 (1851).

Lechı́a dentifrons, Stål, Berlin Ent. Zeitschr. x, p. 393 (1866).

\section{$\checkmark$ Genus Scarpanta, Stål.}

II cm. Afric iv, pp. 236, 240 (1866).

Body oblong, compressed: head much narrower than the thorax, vertex rery short, concealed by the thorax : antenuo very short, first joint hardly visible: ocelli distinet : thorax compressly-elevated on the dise, elevated part flat, a little sloped forwards, anteriorly truneated, produced, covering the vertex, on both sides acutely margined or terminated by a ridge reaching the base: scutellum tricarinate: tegmina very ample; very greatly decumbent; gradually anplified beyond the middle; truneated at the apex, remotely veined; furnished throughout with transverse veinlets irregularly scattered, remote; costal area broad, remotely reticulate: the elevated dorsal part of the abdomen emitting a slender, erect, process : feet moderate, simple: last tibiø bispinoso (Stål).

\section{$\checkmark$ 102. Scarpanta comma, Walker.}

$\checkmark$ opeciloptera comma, Walker, List Hom. B. M. ii, p. 417 (1851).

Scarpanta comma, Stål, Ofvers. K. V.-A. Förh. p. 490 (1862).

8. Body buff : abdomen powdered with white, valves and other appendages at the tip large : legs tawny : anterior feet and tips of the anterior tibie and of the hind feet, black : tegmina buff, a very short and slender, slightly oblique, black streak on the disc, an oblong black dot near the hind border at one-third of the length from the base; veins buff : wings milk white. Body long, $9 \frac{1}{2}$; teg., $37 \frac{1}{2}$ millins.

Reported from Silhat.

$$
\checkmark \odot \text { Genus Flata, Fabricius, Stål. }
$$

Ent. Syst. Snppt. pp. 511, 517 (1798); Stål, Berlin Eint. Zcitsclır. vi, p. 313 (1862) ; Hem. Afric. iv, pp. 236, 241 (1866).

$\int$ It inclndes ${ }^{\circ}$ Colobesthes, Am. \& Serv., Hist. Nayto. Ins. ITém., p. 522 (1. l:3); Cromna, Walker, J. Linn. Soc. Zool, i, p. 85 (1856) ; and I'hyllyphanta, Au. \& Serr.' 1. c., p. 523 (1813). 
Body oblong, compressed : head narrower than the thorax, varying in shape; vertex short, concenled; frons sometimes tumis or conically produced at the base: ocelli distinct: antenno very short: thorax anteriorly somewhat produced, covering the vertex : seutellum more or less distinctly tricarinate: tegmina very ample, very greatly decumbent, gradually amplified towards the apex, truneated at the apex, moderately densely veined, most, often all, the transverse veinlets irregularly seattered, veinlets rarely arranged in one or two irregular rows towards the apex, costal area irregularly reticulated : feet simple, last tibio bispinoso (Stal). ' Type, Flata ocellata, Fabr.

\section{$\checkmark c$ 103. Flata ocellata, Fabricius.}

ᄂ o Cicada ocellata, Fabr., Syst. Ent. p. 682 (1775); Spec. Ins. ii, p. 322 (1781); Mant. Ins. ii, p. 268 (1787); Ent. Syst. iv, p. 27 (179.1), excl. syn. de Géer.

Flata ocellata, Fabr., Ent. Syst. Suppt., p. 517 (1798) ; Syst. Rhyng., p. 49 (1803), Stål, Ofvers. K. V.-A. Förh. p. 489 (1862); Hem. Fabr. ii, p. 107 (1869).

$\checkmark$ O Ricania ocellata, Germar, Mag. Ent. iii, p. $22 \pm$ (1818).

$\checkmark$ c) P(eciloptera ocellata, Bnrm., Handb. Ent. ii (i), p. 162 (1835); Spin., A. S. E. F. viii, p. 4.41 (1839); Walker, List Hom. B. M. ii, pp. 44t, 454 (1851).

$\checkmark$ O Paciloptera stellaris, Walker, List l. c. ii, p. 453 (1851).

$\checkmark 0$ Peciloptera argiolus, Stảl, Ofvers. K. V.-A. Förlı. p. 191 (1855).

Green : tegmina much compressed, posteriorly acntely angulater, green, sprinkled with numerous ocellar ferruginous dots: feet pallid $(F a b r$.$) . In faded specimens the colour is a dirty white or yellow and$ the ferruginous spots become an obscure brown.

Stål's hr. argiolus is thus described:-'Weakly whitish-virescent; frons, thorax, and scutellum tricarinate, the last, however, less so : tegmina sparingly sprinkled with small dull black-sanguineous spots, obsoletely circled whitish ; clavus granulate.' Body long, 6 ; exp. teg., 20 millims.

Reported from Tranquebar.

\section{$\checkmark$ o 104. Flata ferrugata, Fabricius.}

Flata ferrugata, Fabr., Syst. Rhyng. p. 50 (1803); Germar in Thon's Archiv. ii, fasc. 2, p. 19 (1830); Stål, Hem. Fabr. ii, p. 108 (1869).

․ Very palely subtestaceous-flavescent, here and there covered with a whitish powdery substance; wings whitish : apical margins of the two last segments of the abdomen in $q$ at least, black towards the sides. Very close t $6^{\circ} r$. ocellata, Fabr., hardly differ's exeept in coloration unless in having the apical, commissural angle of the tegmina a little less prodneed, somewhat straight, not distinetly acute and thorax with a single less distinet median rilge. Head truncate, vertex very obtusely angulated anteriorly, concealed by the thorax; frons a little 
longer than it is broad beneath the middle, gradually slightly amplified from the base beyond the middle, thence on both sides obtusely rounded furnished with an obtuse median ridge running through it, slightly impressect on both sides within the lateral margins, not tumescent at the base : thorax with a median ridge (Stal). Body long, 8; with teg., $10 \frac{1}{2}$; exp. teg., 24 millims.

Reported from Tranquebar.

$\sqrt{\circ}$ 105. Flata marginella, Guérin.

$\checkmark$ Ricania marginella, Guérin, Voy. La Coquille Zool. ii (2), p. 192 (1830); Icon. Règne Animal Ins., t. 58, f. 6 (1830-34); Voy. Bélanger Ind. Orient. p. 467 (1834.)

$\sqrt{0}$ Peciloptera marginella, Spin., A. S. E. F. (1 sér.) viii, p. 433 (1839); Walker, List Hom. B. M. ii, p. 413 (1851).

$\checkmark \circ$ Nephesa marginella, Walker, J. Linn. S. Zool. i, p. 161 (1857).

$\checkmark$ Pcciloptera fimbriolata, Stảl, Ofvers. K. V.-A. Förh. p 247 (1854).

$\checkmark \cap$ Phyllyphanta fimbriolata, Stål, Freg. Eug. Resa, p. 282 (1859); Ofvors. l. c., p. 159 (1865).

Head greenish-yellow: frons elevated in a small, conical, somewhat projecting proeess: pro- and meso-notum, fresh green with four longitudinal lines converging towards the head, the two internal a little broader and more visible, also some patches on the sides, bright orange or miniaceous red: metanotum and abdomen yellowish-white mingled with some green tints: head beneath, four anterior tibiæ, and anus pale brown : entire body beneath, four anterior femora, and posterior feet very pale green : tegmina falciform, very fresh green, reticulated orange, ontline bordered russet and dentate within, very slender at the side and exterual margin, broader on the posterior margin ; towards the end of this margin, at the second third from the base, there is a small rounded russet patch touching the border and placed near the exterior dilated angle: wings milky-white with slightly greenish and bluish reflections: abdomen and feet greenish-white (Guérin). Long, 6; exp. teg., 19 millims.

Stål's description of his $P$. fimbriolata, which was clearly made from a faded specimen, is :- "Yellow, streak on vertex and thorax and entire limbus of tegmina, fuscous-sanguineons, disc of thorax with two luteous streaks; frons reflexly-margined, furnished on both sides with a very, obsolete ridge towards the base, but towards the apex entirely evanescent; disc of thorax bicarinate; scutellum 4-carinate, with the lateral ridges abrupt belind the middle, somewhat flat between the median ridges; colour of tegmina changing into subvirescent, cellules margined lutescent, clavus granulate inwards ; wings milk-white. $q$ long, 7 ; exp. teg., 20 millims."

Reported from Cochin-China, Malacca, Borneo; the Indian Museum possesses a specimen from Siam.

60 


\section{$\checkmark{ }^{\circ} 106$. Flata intracta, Walker.}

- Paciloptera intracta, Walker, List Hom. B. M. Suppt. p. 116 (1858).

Bright pale grass-green: frons hardly longer than broad, slightly tricarinate, margins not elevated, slightly widened towards the face: pro- and meso-notum slightly tricarinate, the former arched : abdomen pale testaccous: legs partly reddish : tegmina with a pale testaceous marginal line; costa rounded; tip and interior angle somewhat rounded, especially the former; the exterior border hardly rounded, interior border tuberculate; veins and transverse veinlets numerous: wings whito. Body long, $6 \frac{1}{4}$; teg., 19 millims.

Reported from the Punjab.

- 107. Flata flaccida, Walker.

Flata flaccida, Walker, Ins. Saund. Hom., p. 50 (1858).

Pale testaceous : vertex elongated, narrower towards the front, with elevated borders : antennæ black: thorax tricarinate: abdomen somewhat paler than the thorax: anterior tibio and anterior tarsi mostly piceous: tegmina with a few minute pustules, veins very numerons, especially along the margin : wings white (Walker). Body long, 121 ; teg., 50 millims.

Reported from India.

- 108. Flata indocilis, Walker.

- Peciloptera inclocilis, Walker, Ins. Saund. Hom. p. 55 (1858).

\$. Testaccous : vertex covered by the pronotum; frons not longer than broad, widening a little towards the face, with a slightly elevated border, tricarinate; face lanceolate, ecarinate : pronotum transverse, distinctly carinate, conical in front, slightly concave behind: mesonotum ecarinate : ablomen and legs whitish testaceous : tegmina with numerous discal veins and transverse veinlets, slightly convex along the costa, rectangular, and hardly rounded at the tips, straight along the exterior border, interior angle acutely rectangular, marginal veinlets rather short, mostly forked along the exterior border: wings white (Walker). Body long, $6 \frac{1}{4}$; teg., $16 \frac{3}{4}$ millims.

Reported from India.

- 109. Frata angulifera, Walker.

O Cromna angulifera, Walker, Ins. Saund. Hom. p. 57 (1858).

․ Testaceous varied with green: head elongate, acutely conical; frons with elevated borders, ecarinate; face lanceolate: disc of thorax 
flat, slightly carinate on each side ; pronotum transverse, slightly arched: tegmina green, slightly testaceous along the interior border, with few veins and very few transverse veinlets on the dise, the marginal veinlets numerous, moderately long, costa convex for two-thirds of the length from the base, very slightly coneave from thence to the tip which is rectangular like the interior angle, exterior border straight: wings white (Waller). Body long, $4 \frac{1}{4}$; teg., $10 \frac{1}{2}$ millims.

Reported from India.

\section{- 110. Flata marginalis, Signoret.}

\section{Phylliphanta marginalis, Signoret, A. S. E. F. (4 sér.) ii, p. 125 (1862).}

Green-yellow, a little lighter beneath: tip of the head and outlino of tho tegmina yellowish-brown: wings whitish: heat acmminate in front and covered almost entirely by the pronotum which is extemied well beyond the eyes and allows only the eephalic prolongation of the head to be seen, then direeted down wards it changes its contonr or outline beyond the eyes by proceeding abruptly forwards in forming a right angle ; anterior margin rounded very convex, posterior margin concave : mesonotum very broad, convex, rounded in front, extremity rouncled, meclian part flat, bounded by two complete ridges, on cach side of which are two incomplete ridges which proceed from the anterior border. Lower angle of tegmina very acute, upper margin rounded, external angle rounded, external margin almost straight, sutural margin sinuate and rugose; external cubital vein much elevated and furnished on each sile with a number of small tubercles which as well as the vein are of a yellow brown: wings whitish: abdomen yellowish, genitalia brownish : fect yellow, anterior tibiæ, brownish (Sign.). Long, teg. extended, 18 millims.

Reported from Cochin-China.

\section{$\checkmark \circ 111$. Flata falcata, Guérin.}

○ Paciloptera falcata, Guérin, Voy. Bélanger Ind. Orient. Zool., p. 469, t. 3, f. 5 (1834); Spin., A. S. E. F. viii, p. 430 (1839).

$\checkmark$ Colobesthes falcata, Am. \& Serv., Hist. Nat. Ins. Hém., p. 523 (1S \$3); Walker, List Hom. B. M. ii, p. 439 (1851);

( Colobesthes albiplana, Walker, J. Linn. Soo. Zool, i, p. 92 (1856), p. 161 (1S5̌) ; x, p. 180 (1867).

Entire body and feet pale golden-yellow ; liead carinate on the sides, eyes black : thorax subcarinate : tegmina subtriangular, anterior margin rounded, very narrow at the base, external margin as large as the anterior margin, of a yellowish-white with an immense number of palo golden-yellow veinlets : wings milky white, scmi-trausparent, posteriorly 
dilated: abdomen eompressed, yellowish; feet rather short, tarsi a little brunneons (Guérin). Long, 14; exp. 57 millims.

Reported from Borneo, Sumatra, Java, Singapore, Malacea, Burma.

Walker describes his $C$. albiplana thus:-“White: tegmina convex in front, rectangular at the tips, straight and quadrate from thence to the interior angle which is attenuated and very acute: posterior margin straight : wings hardly aenminate at the tips."

\section{$\checkmark \circ 112$. Flata conspersa, Walker.}

Colobesthes conspersa, Walker, List Hom. B. M. ii, p. 440 (1851) ; Stål, Ofvers. K. V.-A. Förh. p. 490 (1S62).

$\delta$, $q$. Body tawny: head narrower than the thorax; vertex very short; frons conical above, fore-part paler: abdomen obeonical, longer than the thorax, powdered with white: legs pale tawny: tegmina pale fawn-eolour, sprinkled with black which is chiefly on the transverse veins, rounded on the anterior margin, truncate at a right angle along the tip, sinnate on the posterior margin at the tip of which they are prodneed into an acute angle or hook; veins pale tawny: wings milkwhite. Body long, 11-15; teg., 38-46 millims.

Reported from India, Assam, Silhat: the Indian Museum possesses specimens from Sibságar, Sikkim, Caleutta.

\section{o 113. Flata acdtipennis, Walker.
Cromna acutipennis, Walker, J. Linn. Soc. Zool. i, p. 85 (1856).}

Green, paler beneath: head and thorax with testaceous stripes; tegmina with a brown line extending from near the tip of the eosta to one-third of the length of the hind border from the interior angle :

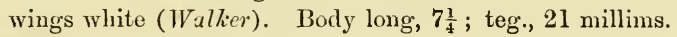

Reported from Malacea, Burma.

\section{- 114. Flata lutescens, Walker.}

$\checkmark$ o Peciloptera lutescens, Walker, List Hom. B. M. Suppt., p. 117 (1858).

Flata lutescens, Stãl, Ofvers. K. V.-A. Förh. p. 490 (1862).

8. Testaceous: vertex a little broader than long, indistinetly triearinate, borders slightly elevated: pronotum arehed, slightly uniearinate: mesonotum indistinetly tricarinate : dorsal apical appendage of abdomen long, slender, eurved, suleate : tegmina very slightly rounded along the costa ; tip rounded; exterior border straight forming a welldefined right angle with the interior border which is tubereulate: veins and transverse veinlets rather nnmerous; marginal veinlets rather long: wings white (Waller). Body long, $6 \frac{1}{4} ;$ teg., 19 millims.

Reported from N. Iudia. 


\section{$\checkmark \odot$ 115. Flata albata, Stål.}

Flata albata, Stål, Ofvers. K. V.-A. Förh. xi, p. 247 (1854) : Freg. Eug. Resa, p. 283 (1859).

Whitish : tegmina within two fuscescent bands at the apex, behind the middle with three, small, oblique, abbreviated, black bands ; geniculæ, tibiæ, and anterior tarsi, black-fuscous (Stål). Body long, 10; exp. teg., 33 millims.

Reported from Malacca.

- 116. Flata marginata, Walker.

C Colobesthes marginata, Walker, J. Linn. Soc. Zool. i, p. 92 (15j6).

Greenish-white: frons not broader than long, with a slightly elevated border and a slight ridge : sides slightly rounded: mesonotum on each side with a testaceous stripe which inchiles a luteous line: tegmina minutely tuberculate towards the base, rounded in front, rectangular at the tips, straight and quadrate from thence to the hind angle which is attenuated and acute: hind border straight, a pale lutcous marginal band extending from three-fourths of the length of the costa

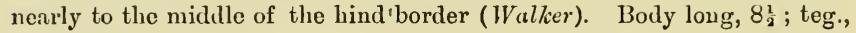
$37 \frac{1}{2}$ millims.

Reported from Malacca, Burma.

\section{Vo 117. Flita PRyeri, Distant.}

$\checkmark$ O Flata (Colobesthes) pryeri, Distant, Trans. Ent. Soc., p. 153 (1880).

Body above and tegmina pale greenish; wings pale greenish white: tegmina with the costal, inner, and outer margins (the last only half the length from the apex) narrowly and obscurely luteous, and with an angular black line on the disc, about half way from the base and about two-thirds the distance from the costal margin : body beneath and legs somewhat luteous. Face broad, convex, carinate in the middle, sides amplified: posterior angle of tegmina attenuated and acute, expanse at outer margin twice that of width near base : two well developed transverse, somewhat irregular, series of veinlets preceding outer margin and a third one situated midway between these and the reticulated area ( $D$ is. tant). Body long, 10 ; exp. teg., 36 millims.

Reported from Borneo, Penang.

\section{$\checkmark$ o 118. Flata antica, Walker.}

$\checkmark \vartheta$ Paciloptera antica, Walker (nec Westw.), List Hom. B. M. ii, p. 456 (1851). Flata antica, Stål, Ofvers. K. V.-A. Förh. p. 490 (1862).

64 
ㅇ. Body yellowish-green: head very short; vertex extremely short, apparently almost concealed by the pronotum; frons flat, a little broader towards the clypeus, pale luteous and slightly rounded on each side, margins reflexed, very slightly sinuate where it joins the clypens with a median ridge extending three-fourths of its length: clypens slightly rounded, obliquely streaked on both sides: mesonotum with three green stripes of which the median follows a ridge: pectus luteous; abdomen obconical, crested, pale green and tinged with white above: legs pale luteous : tegmina whitish green, dilated and tuberculated along more than half the length of the hind border, truncated at the tips which form right angles with the hind borders; veins bright luteous especially along the fore-border towards the base where the whole wing

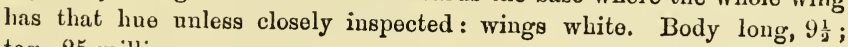
teg., 25 millims.

Reported from India.

Species of uncertain position.

\section{c119. Flata coromandelica, Spinola.}

Peciloptera coromandelica, Spin., A. S. E. F. (1 sér.) viii, p. 440 (1839); Walker, List Hom. B. MI. ii, p. 440 (1851).

$\delta$, \&. Head, dorsum of thorax, tegmina, grass-green, the rest including wings of a lighter green, veins deeper : second joint of the antennæ, exterior border of the external flap, and of the entire discoidal space of the tegmina orange : third joint of the antennæ and its filament, spines on tibir and tarsi, black.

Reported from Coromandel.

\section{Flata truncata, Linnæus.}

J Cicada truncata, Linn., Syst. Nat. ii, p. 704 (1758); Amæn. Acad. vi, p. 399 (1763).

b Fulgora truncata, Olivier, Eno. Méth. vi, p. 571 (1791); Fabricius, Syst. Ent. p. 674 (1775); Spec. Ins. ii, p. 815 (1781); Mant. Ins. ii, p. 261 (1787); Ent. Syst. iv, p. 4 (1794); Syst. Rhyng., p. 4 (1803).

C P(eciloptera truncata, Westwood, Trans. Linn. Soo. xviii, p. 151 (1841); Walker, List Hom. B. B1. ii, p. 446 (1851).

Whitish-green, wings deflexed, compressed, posteriorly truncated, frons a little advanced, obtuse. (Linn.)

Reported from India, Java.

\section{Flata addita, Walker.}

${ }^{3}$ Pociloptera addita, Walker, List Hom. B. Mr. ii, p. 448 (1851).

(3) P(eciloptera plana, Walker, List 1. c., p. 463 (1851).

Flata adılita, Stâl, Ofvers. K. V.-A. Förh. p. 489 (1862). 
Walker makes his species the same as Stoll's 'La Cigale chappo verte (Cigales, p. 76, t. 19, f. 103), which comes from Madras. Stoll describes it as having head and eyes white, body and feet pale yellowish green, tegmina green, powdered with white farinose, wings white. Walker's $P$. addita has body pale green; antennæ yellow; abdomen greenish yellow powdered with white: legs pale green: feet tawny: tegmina pale green powdered with white; veins green : wings milk-white. Walker'd $P$. plana is only a faded specimen of $P$. addita.

§. Body long, 6-7; teg., 25-29 millims.

\section{$\checkmark$ 122. Flata lactifera, Walker.}

$>$ Peciloptera lactifera, Walker, List Hom. B. M. ii, p. 450 (1851).

Body, legs and veins on tegmina pale stramineous; the two former powdered with white: mesonotum with two luteous stripes; tegmina and wings white, tegmina with numerous longitudinal and few transverse veins, anterior margin slightly rounded and along it a row of oblique, parallel, here and there forked, transverse veins. Body long, $6 \frac{1}{4}$; tog., 21 millims.

Reported from N. India.

- 123. Flata distinctigsima, Walker.

Preciloptera distinctissima, Walker, List Hom. B. M. Suppt., p. 114(1858).

Flata distinctissima, Stål, Ofvers. K. V.-A. Förh. p. 490 (1862).

Pale green or whitish or testaceous : mesonotum with four more or less distinct luteous or testaceous stripes : abdomen and legs pale testaceous : tegmina with a reddish marginal line extending from the apical part of the costa to the base of the interior border which is slightly tuberculate; veins and transverse veinlets, testaceous: wings white. Loug, $7 \frac{1}{4}$; teg., 21 millims.

Reported from N. China.

\section{$\checkmark$ 124. Flata guttularis, Walker.}

o Preciloptera guttularis, Walker, List Hom. B. M. Suppt., p. 111 (1858).

Flata guttularis, Btål, Ofvers. K. V.-A. Förh. p. 490 (1862).

Testaceous, whitish pubescent, rarely pale green : abdomen generally white : tegmina rarely tinged with green towards the base and along the costa, with about 18 minute black dots : wings white. Long,

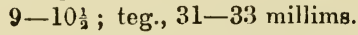

Reported from N. China.

66 
$\checkmark$ 125. Flata (?) triscripta, Walker.

Flata triscripta, Walker, Ins. Saund., p. 50 (1858.)

Green, thickly covered with white tomentum : antenno, tarsi, and fore-tibir, black : wings white, iridescent : vertex and frons elongated, their borders elevated, parallel : pronotum much arched : tegmina with a slight green tinge, slightly testaceous along the borders and with two grayish, eurved, parallel bands, the one marginal the other submarginal; three black discal lines of which the fore one forms a very obtuse angle, much longer than the other two, between which and the interior border the veins are black; costa and exterior border rounded; veins numerous ;

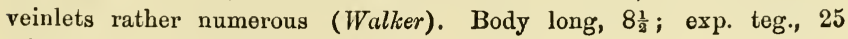
millims.

Reported from Penang.

$\checkmark \odot$ 126. Flata (?) rectimargo, Walker.
$\checkmark$ Peciloptera rectimargo, Walker, Ins. Sand., p. 51 (1858).

Testaceous with a very slight rosy tinge : abdomen whitish testaceous : tegmina very pale rosy; wings white. $\delta$ has fore tibio, black : tegmina with a luteous tinge along part of both exterior and interior borders. \& has the tegmina with a luteous stripe near the costa. Body long, $10 \frac{1}{2}-12 \frac{1}{2}$; teg., $46-50$ millims.

Roported from Penang.

\section{Flata sinensis, Walker.}

- Peciloptera sinensis, Walker, List Hom. B. M. ii, p. 451 (1851).

$\checkmark$ Peciloptera cereris, Stål, Ofvers. K. V.-A. Förh. p. 247 (1854).

$\checkmark$ () Phyllyphanta cereris, Stål, Freg. Eug. Resa, Hem., p. 282 (1859); Ofvers. 1. c., p. 489 (1862).

§, ‥ Weak virescent: head briefly conically produced; frons reflexly margined with a very obsolete median ridge: thorax somewhat granulated towards the sides, with a slight ridge: scutellum parallel with three obsolete grass-green ridges, the lateral pair very obsolete: tegmina scarcely twice as long as broad, internal apical angle acutely produced; the exterior apical limbus and the internal limbus behind the middle densely adorned with small fuscous spots; clavus densely and external limbus towards the base sparingly, granulated; very many cells furnished with a weaker granule or somewhat elevated spot (Stål). Long, 9 ; exp. teg., 22 millims.

Reported from Hong-Kong. 


$$
\checkmark \text { Gentis Seriza, Stảl. }
$$

Berlin Ent. Zeitschr. vi, p. 312 (1862).

Head narrower than the thorax; vertex transverse, concealcd : frons of variable length, sometimes subtumid at the base, lateral margins somewhat acutish and slightly reflexed: obsolete ocelli present: antennæ short, first joint very short: thorax slightly arcuate, prominent in a small tooth anteriorly on both sides at the eyes; thorax and scutellum without ridges : tegmina moderately ample, contracted slightly near the apex, subtruncated at the apex, apical angles rounded, sprinkled irregularly with transverse veinlets, furnished between the apex of the clavus and of the subradial vein with a continued row of transverse veiulets, the space between the subradial vein and cubitus varying in length and breadtl, and furnished towards the apex with transverse veinlets : veins on clavus united towards the apex: fpet moderate, simple; last tibio bispinose behind the middle. Allied to Flata, Fabro but very distinct in the structure and form of the tegmina (Stdl) : type, P. vidua, Stål.

\section{5) 128. Seliza vidda, Stål.}

("Pceciloptera vidua, Stäl, Ofvers. K. V.-A. Förh. xi, p. 248 (1854) ; Freg. Eug. Resa, Ins. p. 281 (1859).

Seliza vidua, Stål, Berlin Ent. Zeitschr. vi, p. 812 (1862).

Yellow-testaceous ; frons furnished at the base with an arcuate ridge, and towards the base between the eyes with a longitudinal ridge: tegmina subparallel, one and a half times longer than the breadth, behind the middle both outwardly and inwardly sinuate, roundly truncated at the apex, adorned with a broad black-fuscous patch, clavus inwardly tuberculate. Head yellow testaceous, at the base itself with a subarcuate transverse ridge; frons somewhat longer than the breadth, reflexlymargined, furnished with a small ridge towards the base: antenno flavescent, third joint fuscous : thorax yellow-testaceous, semicircularly subelevated behind the head : scutellum yellow-testaceous, convex, almost four times longer than the thorax : tegmina one aud half times longer than the breadth, rounded outwardly from the base, then subparallel, sinuated outwardly and inwardly behind the middle, roundly truncate at the apex, testaceous-yellow; a large, longitudinal patci, abrupt before the middle, black fuscous ; clavus longitudinally carinately elevated inwards : beneath with feet testaceous-yellow (Stål). Long, 5 ; exp. teg., 14 millims.

Reported from Malacca, India.

129. Seliza troncata, Walker.

$\checkmark$ ○ Flatoides truncatus, Walker, List Hom. B. M. ii, p. 419 (1851).

Seliza truncata, Stål, Ofvers. K. V.-A. Förh., p. 490 (1862).

68 
d. Body tawny, darker here and there: head a little narrower than the thorax; vertex conical, slightly coneave; frons much larger than broad, widening from the vertex to the clypeus where it is rounded, reflexly marginate, and with a slight median ridge: eyes striped: thorax rounded in front slightly sinuate behind; nearly four times broader than long: mesonotum ferruginous, more than twice as long as the pronotum : abdomen luteous, obconical, not longer than the thorax : genitalia consisting of two curved appendages the tips of which cross each other; the lower one compressed, deep, grooved; the upper one longer and more slender: legs tawny: tegmina truncate at the tips, pale tawny: veins darker, very numerous towards the tips : wings almost colourless, brown towards the tips; veins brown, tawny at the base (Walker). Body long, 5 ; teg., $14 \frac{1}{2}$ millims.

Reported from N. India.

\section{Seliza ferrdainea, Walker.}

Elidiptera ferruginea, Walker, List Hom. B. M. ii, p. 333 (1851).

Seliza ferruginea, Stål, K. V.-A. Förh., p. 490 (1862).

8. Body tawny; head much narrower than the thorax; its two segments divided by a suture which forms an angle towards the hind border; hind segment yellow, piceous on the dise, its back forming a right angle with each side on which the eye is placed: fore segment piceous, rounded in front; frons rather broad, rounded on each side, piceous next the crown : rostrum tawny, reaching the hind coxæ: antennw ferruginous, rather short, second joint nearly twice longer than the first: pronotum as long as the head very finely rugulose, somewhat truncated in front, slightly sinuate behind, disc of the mesonotum, pieeous : abdomen obconical, not longer than the thorax: legs tawny, grooved, rather broad; a tooth on-each hind tibia near the rip: tegmina ferruginous, darker at the tips, partly inflated at the base and along the hind border, near whose base there are a few rows of small tubercles; reticulated part occupying full one-third of the wing; foreborder slightly convex not dilated; a row of numerous short parallel veinlets between it and the first longitudinal vein; veins ferruginous: wings grayish (Walleer). Body long, $6 \frac{1}{2}$; teg., $16 \frac{1}{2}$ millims.

Reported from India.

\section{$\checkmark$ o 131. Sriliza lignaria, Walker.}

Flatoides lignarius, Walker, List Hom. B. M. ii, p. 413 (1851).

$\downarrow$ Flatoides minor, Walker, 1. c., p. 417 (1851).

$\Varangle$ Flatoides dubitans, Walker, l. c., Suppt., p. 101 (1858).

- Paciloptera punctifrons, Walker, 1. c., Suppt., p. 118 (1858).

Seliza lignaria, Stàl, Ofvers. K. V.-A. Förh., p. 489 (1862). 
8. Body ferruginous : vertex with a large piccous spot on each side; frons and clypeus, tawny; mesonotum piceous: abdomen a little longer than the thorax, genitalia very long, upper one armed near the base with two spines, curved downwards towards the tip which approaches the middle of the tip of the lower one, the latter is very deep, especially at the tip where its depth is almost equal to its length : legs tawny : tegmina ferruginous, moderately broad, with a few darker spots; dises of the areolas almost colourless; veins brown; costal margin much dilated towards the base and along it a row of parallel transverse veins : wings gray, paler towards the base. $q$ has the abdomen shorter than the thorax, tip ronnded and along it a groove with a transverse ridge. Body long, $5 \frac{1}{4}$; teg., $16 \frac{1}{2}$ millims.

Reported from Hong. Kong.

\section{- Genus Fuatoides, Guérin.}

Icon. Règno Animal, Texte, Ins., p. 362 (1838) : Stål, Ilem. Afric. iv, pp. 237, 248 (1866) : includes 'Phalenomorpha, Am. \&' Serv. Hist. Nat. Ins. Hém., p. 525 (1843); Stål, Berlin Ent. Zeitschr. vi, p. 312 (1862).

Body oblong, depressed, head produced before the eyes; vertex flat, sides parallel, confused anteriorly with the produced base of the frons which is not ridged : rostrum rather long, antennæ short: thorax elevated and flat on the disc, broadly sinuate at the base, sides flattened : tegmina ample, suboblong, costal membrane broad: feet simple, last tibir bispinose; last dorsal segment of the abdomen in \& furnished with a large produced plate, rounded at the apex (Stal).

\section{$\checkmark \partial$ 132. Fuatoides indica, Walker.}

- Elidiptera indica, Walker, List Hom. B. M. ii, p. 330 (1851).

Flatoides indica, Stål, Ofvers. K. V.-A. Förh., p. 489 (1862).

§. Body pale tawny, mottled with darker colonr: head conical, not longer than the pronotum, somewhat sinuate and with a brown stripe above, yellow and marked with a darker colour beneath where it widens to the clypeus : rostrum luteous, reaching to the hind coxæ ; eyes very prominent: antennæ luteous, rather long, second joint longer than the first; pronotum conical, slightly excavated and indistinctly angular on the hind border: disc of the mesonotum very concave; a ridge on each side towards the tip which forms an acute angle: abdomen slightly obconical, a little longer and broader than the thorax : legs pale tawny, slightly grooved: a single black-tipped spine on each hind tibia : tegmina very pale tawny, almost colourless towards the tips, adorned on the veins with numerous brown dots, some of which are confluent and with a transverse brown band at one-third from the base; 
veins pale tawny; a broad convex membrane along the fore-border and at the tip slightly waved, furnished with numerous veins, most of which are connected by a band of transverse veins: wings whitish : veins pale stramineous (Wallier). Body long, $10 \frac{1}{2}$; teg., 25 millims.

Reported from F'rench rocks near Madras.

- 133. Flatoides fimbria, Walker.

O Elidiptera fimbria, Walker, List Hom. B. M. ii, p. 331 (1851).

Flatoides fimbria, Stål, Ofvers. K. V.-A. Förh., p. 489 (1862).

\&. Body pale dull luteous : head conical, a little longer than the pronotum; lateral margins slightly carinate; frons widest between the eyes: rostrum tawny, nearly reaching the hind coxæ: eyes not prominent: pronotum truncated in front, with a slight median ridge; hardly excavated on the hind border, paler than the head: mesonotum pale brown with two ridges which are oblique in front: abdomen elliptical, longer than the thorax, marked with black at the base: legs tawny, slightly grooved; a single black-tipped spine near the tip of each hind tibia: tegmina pale yellowish-brown with small irregular dark brown marks which are chiefly on the veins, rounded, much widened and furnished with numerous veins along the fore-border; veins pale tawny : wings pale gray, veins tawny (Walker). Body long, $10 \frac{1}{2}$; teg., 27 millims.

Reported from Silhat.

\section{$\checkmark$ 134. Flatoides principalis, Stäl.}

Flatoides principalis, Stål, Ofvers. K. V.-A. Förh., p. 159 (1865).

\&. Testaceous-stramineous; tegmina turning into pale olivaceous, very slightly narrowed behind the middle, broadly rounded at the apex: wings sordid whitish. Head fairly produced before the eyes; vertex somewhat longer than the thorax, a little longer than broad, obtuse at the apex and sinuated on both sides; frons much longer than broad, fairly narrowed upwards, rounded on both sides towards the apex; a ridge proceeding from the base beyond the middle, distinct, furnished in the middle with two small ridges : clypeus without a ridge: median part of the thorax, elevated, somewliat concave anteriorly, rounded at the apex : scutellum with an abbreviated transverse ridge a little before the middle, recurved on both sides, and continued to the apex, black-fuscous at the apex : costal part of the tegmina transversely veined, very broad, narrowed towards the apex, occupying towards the base more than a third part of the tegmina; margins entire, not eroded: last pair of tibiæ bispinose (Stål). Long, 15 ; exp. teg., 38 millims.

Reported from Malacca, Ligor. 


\section{1] 135. Flatoides (?) emarginatus, Walker.}

Flatoides emarginatus, Walker, J. Linn. Soc. Zool. i, p. 89 (1856).

Blackish : head, pectus, and legs dull dark testaceous; frons about twice broader than long with an elevated border and with three short ridges on the hind part: tegmina and wings blackish, a white limpid spot beyond the middle of the costa of the tegmina, which are slightly

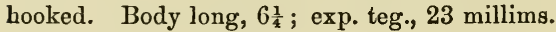

Reported from Singapore.

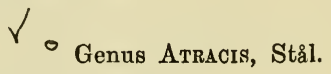

Hem. Afric. iv, pp. 237, 250 (1866).

Body oblong, depressed: head much narrower than the thorax, more or less prominulous before the eyes : ocelli present : antennœ short : disc of thorax elevated and flat; thorax broadly sinuated at the base: clavus granulated at the base : last segment of the abdomen in $q$ produced in a large plate which is rounded at the apex : feet simple, last tibir unispinose (Stål).

\section{$\checkmark$ - 136. Atracis pruinosa, Walker.}

- Elidiptera pruinosa, Walker, List Hom. B. M. Suppt., p. 75 (1858).

- Flatoides pruinosa, Stål, Ofvers. K. V.-A. Förh., p. 439 (1862).

Atracis pruinosa, Stal, Hem. Afric. iv, p. 250 (1866).

Sordid testaceous : head and pronotum slightly marked with black: disc of the mesonotum mostly black: tegmina with a slight greyish bloom and slight, small, irregular and variable, brown or black marks; costal margin much dilated: wings greyish with darker veins. Vertex much broader than long, slightly angular in front, with a slight ridge and with elevated borders; frons a little longer than broad, with two nearly obsolete ridges and with slightly elevated borders; pronotum somewhat truncated anteriorly and with a very slight ridge (Walker)

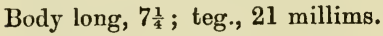

Reported from N. China.

\section{- Genus Copsyrna, Stål.}

Rio Jan. Hem. ii, p. 69 (1862); Hem. Afric. iv, p. 237 (1866).

Body somewhat cylindrical or compressed : head much narrower than the thorax : antenne standing up a little beyond the anterior margin of the genæ, second joint short or very short : ocelli not visible : tegmin rounded at the apex : last pair of tibiø unispinose. 
- 137. Copsyrna maculata, Guérin.

o Paciloptera maculata, Guérin, Icon. Règne An.t. 58, f. 7 (1830-34); Voy. Bél. Ind. Orient., p. 170 (1831) : Spin., A. S. E. F. viii, p. 423 (1839) : Walker, List Hom. B. M. ii, p. 413 (1851) ; J. Linn. Soc. Zool. i, p. 92 (1856), p. 161 (1857).

Copsyrna maculata, Stål, Rio Jan. Hem. ii, p. 69 (1862).

Head, thorax, and wings yellowish-white, a little orange on the sides of the mesonotum and at the base of tegmina: head with an oblong patch in the middle of the frons, two approximated dots in the middle of the pronotum, two longitudinal parallel lines in the middle of the mesonotum, and four small dots on the posterior lateral margins, black: tegmina oblong, rounded at the tip, with several brown spots, almost black towards the anterior margin, quadrate, in several places confluent, leaving small white spaces in their midst and forming, towards the tip, three arched parallel bands on the external margin: wings white: beneath and feet pale yellow (Guérin). Long, 12 ; exp. teg., 50 millims.

Reported from Java, Malacca, Singapore.

\section{$\checkmark \circ$ Genus Nepiesa, Amyot \& Serville.}

Hist. Nat. Ins. Hém., p. 527 (1843): Walker. List. Hom. B. Mr. ii, p. (1851) : Stål, Hem. Afric. iv, p. 237 (1866); Ofvers. K. V.-A. Förh., p. 773 (1870).

Head broad, straight or scarcely arched beyond the eyes; vertex in the form of a very short margin beyond the pronotum, with a slight transverse ridge which separates it from the frons which is broad and has neither a distinct longitudinal ridge nor a transverse groove : ocelli apparently absent: pronotum without a longitudinal median ridge; mesonotum with three almost parallel elevated lines: tegmina with longitudinal and forked veins; of a very fine substance, although slightly opaque; truncated at the tip; margins straight, a little broader at the tip than at the base; external border with very distinct transverse veins ; wings almost as long as the tegmina and much broader at the tip than at the base: vulvar plates in $q$ broad, in form of an elongated cone, extending beyond the tip of the abdomen, with a sabre-shaped oviduct, divided into two equal plates, very robust and usually hidden by the vulvar plates: last pair of tibiæ unispinose $(A . \& S S$.) Differs from Copsyrna in having the tegmina truncated at the apex and the head only a little narrower than the thorax.

\section{$\checkmark$ 138. Nephesa rosea, Spinola.}

- Ricania rosea, Spinola, A. S. E. F. viii, p. 400 (1839).

Nephesa rosea, Am. \& Serv., Hist. Nat. Ins. Hém., p. 528 (1843); Walker, List Hom. B. M. ii, p. 433 (1851); J. Linn. Soc. Zool.i, p. 91 (1856) : Stål, Ofvers. K. V.-A Förh., p. 489 (1862); p. 773 (1870); Berlin Ent. Zeitschr. x, p. 393 (1866).

$\checkmark$ O Pociloptera completa, Walker, 1. c., p. 241 (1851).

$\checkmark$ Flata matutina, Walker, l. c., p. 437 (1851). 
б, f. Head, thorax, and tegmina of a slight rosy colour : wings white: body beneath and feet of a pale yellowish colour (A. \& S.). Loug, 22 millims.

Reported from Philippines, Java, Singapore.

Species of doubtful occurrence.

$\checkmark \bigcirc$ 138. Pæciloptera luteimargo, Walker, J. Linn. Soc. Zool. i, p. 92 (1856).

Green, with a slight testaceous tinge: frons a little longer than broad with the border slightly elevated and with a slight ridge; sides rounded: thorax ecarinate: pronotum nearly semicircular, extending over the vertex: mesonotum broader than long: tegmina subquadrate at the tips, about which there is a luteous brown-bordered band: wings

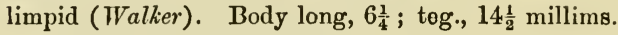

Reported from Singapore.

$\checkmark$ ) 139. Peciloptera niveina, Walker, J. Linn. Soc. Zool. i, p. 92 (1856).

White : in structure like the preceding: tegmina with a testaceous marginal band which extends from two-thirds of the length of the costa

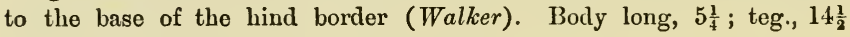
millims.

Reported from Mount Ophir (Singapore).

$\therefore$ 140. Flata lyncea, Fabricius, Ent. Syst. iv, p. 42 (1794); Syst Rliyng., p. 55 (1803).

Small : face flavescent, markings black : frons glaucous with a dull black dot on both sides cinctured flavescent and a small line in the middle : thorax glaucous with two rounded dull black spots anteriorly: tegmina and wings hyaline, exterior margin flavescent ( $F a b r$. .).

Reported from India. 
Notes on Indian Rliynchota. No. 6.-Adilenila and Index.

By E. T. Athinson, B. A., President of the Societr.

[Read November 4th, 1885.]

o Genus Pשellopsaltria, Stål.

J. A. S. B. liii, (2), p. 211.

Basal cell of tegmina irregularly four or somewhat five-angled, very often broad; ulnar veins altogether distant at the base: head broad, obtuse, with the eyes broader than the scutellum; vertex more than twice broader than the eyes; ocelli twice and often thrice more distant from the eyes than from each other'; frons slightly or moderately eonvex, at the base before the vertex searcely or but a little prominent: thorax angulated on both sides : first femora without distinct spines; metasternum elevated, the elevated part furrowed, and somewhat sinuately truncated (Stal, Hem. Afr. iv, p. 2).

u 1. Pecilopsaltria affinis, Fabricius.

J. A. S. B. liii, (2), p. 211, no. 2.

Body of a moderate size, spotted black : margin of thorax dilated : tegmina obscurely greyish, posterior margin broadly hyaline with several fuscous spots: wings much shorter, fulvous, black before the margin, striated fulvous, margin itself not hyaline but fulvous ( $F a b r$.).

$\delta$ Q. Pale olivaceous-flavescent or virescent: lores (margin excepted), clypeus (ridge excepted), two small apical spots on, and two 
transverse lines towards, the base of the frons, a band on the genn, a spot inclnding the ocelli, two spots at the eyes and a transverse line (sometines obliternted) on the vertex, a broadish lateral intramaryinal line on the thorax, four basal spots (the median pair somewlint large), a narrow oblique lateral line (posteriorly abbreviated), and three small posterior spots on the scutellum, basal limbus of the dorsal segments of the abdomen and a lateral spot on the fonr last ventral segments, black. Tegmina opaque whitish jellow, clouded fuscous, a median spot in the radial area and a spot occupying the middle of the 1-2 paler ulnar areas, the apical areas (the entire eighth area and basal and apical parts of the first area excepted) vitreons, colonrless; ulnar veins marked at the apex and near the apex on both sides with a small fuscons spot: wings lutescent; a narrow streak and tho apical part, outwards broadly, and inwards narrowly, obscurely fuscous; this apical part at the veins and the veinless limbus and anal area, weakly lutescent. Head obtuse, frons slightly convex : lateral apical part of the vertex lying between the frons and the eyes subequal in breadth to the subhasal part of the frons; clypeus sinnately truncated at the apex : ocelli more than twice as distant from each other as from the eyes: sides of thornx much angularly dilated, angles somewhat straight, rounded at the extreme apex: sides of the interior ulnar area somewhat parallel behind the middle: metasternum elevated, longitudinally impressed in the middle, sinuated anteriorly : the veinless limbus of both tegmina and wings of equal breadth (Stål).

- Genus Platrpleura, Amyot \& Serville, Stål.

\section{J. A. S. B. liii, (2), p. 211.}

Body stout, large : head not or scarcely broader than the scutellum, rarely narrower: ocelli rarely a little more than twice as distant from the eyes as from each other : the sides of the thorax much flattened out, foliaceous, horizontal, anterior angles turning towards the middle of the eyes, anterior margin sinuated behind the eyes; posterior limbus broad: basal cell of tegmina broad; ulnar veins emitted from it, distant at the base, interior ulnar area gradually broader towards the apex: entire tympana or the greater part concealed; opercula moderate, transverse, rounded at the apex, slightly valvate (Stal).

\section{a 2. Platypleura ciliaris, Limneus.}

$\checkmark$ Cicada ciliaris, Linn., Syst. Nat. (10th ed.) i, p. 436 (1758); Mns. Lnd. Ulr. p. 155 (1764); Olivier, Enc. Méth. v, p. 757 (1790); Germar in Thon's Arch. ii, (2), p. 2 (1830); Silb., Rev. Ent. ii, p. 78 (183 t) : Stoll, Cig., p. 102, t. 26, f. 147 (1788). 
- Cicada ocellata, De fiéer, Mem. iii, p. 220, t. 33, f. $2-3$ (1773): Olivier, Enc. Métl. v, p. 751. t. 112, f. 3 (1790): Capo.

Tettigonia marmorata, Fabr., Syst. Rhyng. p. 38 (1803), Amboina.

Ceicala marmorata, Gormar; 'Thou's Archiv. ii (2), p. 17 (1830); Silh., Rov. Ent. ii, p. 79 (1831) : Platyplenraid. Sign., B. S. E. F. (6 sér.) i, p. xlii (1881), China.

OOsypleura (?) marmorata, Walker, l. c. p. 24 (1850).

Plat!pleura ciliaris stål, Ifem. Fabr. ii, p. 3 (1869); Ofvors. K. V-A. Förh. p. 500 (1562) ; ill. p. 707 (1570) : Butler, Cist. Ent. i, p. 185 (1874).

Stål (in Hem. Afric. iv, p. 16, 1866) makes P. ocellata, De Géer of Walker, (excl. syn.) and P. capensis, Am. \& Serv., one with ${ }^{\mathrm{D}} P$. hirtipennis, Germar, and also ${ }^{5}$ Cicada plumosa, Germar, a variety of the sa'me species; again (in Ofvers. K. V.-A. Förh., p. 500, 1862) he unites ${ }^{2}$ Civada ocellata, De Gécr, Cicala varia, Olivier, from the Cape, and Platypleura arcuata, Walker (Ins. Saund. p. 1), from Ceram, with P. ciliaris, Linn., but Butler (l. c.) keeps the last two separate. Olivier is the only one that gives India as the locality; and I include the species in our Indian list as it is also recorded from Java and the Philippines, the fanma of which have a marked aflinity with that of India.

Thorax with a rim: tegmina pale with white patches: wings blackish ferruginons, with a yellowish band bent back towards the disc and sometimes triple : abdomen blackish with pale and ciliated rings (Olivier). Head and thorax green, spotted black : tegmina fuscons and variegated einereous, with two whitish spots before the costa, which is virescent at the base: wings dull black with two small lines at the base, and a spot towards the margin, rufous; body cinereous (Fabr.).

\section{Platypleura sphinx, Walker.}

J. A. S. B. liii, (2), p. 213 , no. 6.

8 \&. Body pale tawny, tinged with white, briefly whitish pilose : vertex with two brown bands: rostrum tawny, tip brown reaching tho hind coxæ: antenmæ dark tawny: mesonotnm with four obconical dark brown marks, onter pair long, inner pair short and pointing to two dots of the same colonr: logs pale tawny ; tips of the tibire darker; claws piceous, tawny at the base; first femora with tawny teeth which hardly rise above the surface; hind tibiæ with tawny spines which are piceous at the tips : tegmina whitish, brownish tawny towards the base and having elsewhere some irregular pale brown marks which, here and there, include white spots; veins yellow : wings brown, mostly yellowish white towards the base and having a large spot of the same colonr in the disc, white at the tips with a white spot on the hind border which elsewhere is brown; flaps yellowish-white, with broad brown borders. 


\section{O4. Platypledra celebs, Stảl.}

J. A. S. B. liii, (2), p. 213, no. 7.

శ. Sericeous, above testaceous; beneath with feet greyish : head above and wings sordid flavescent, middle of the vertex and apical latcral band, frons (basal spot excepted), two minute spots behind the middlo of the thorax, two median basal spots on the scutellum, an oblong discoidal spot, and another very large, oblong-obtriangular, lateral spot on both siles, extended from the base beyond the middle, also the dorsum of the abdomen, black : venter fuscous: tegmina clouded pale fuscous and greyish-sericeous from the base beyond the middle, vitreous towards the apex ; anastomoses and the apical and subapieal spots on the longitudinal veins, fuscous: wings very slightly infuscate towards the apex, limbus sordid whitish, very slightly infusente in the middle. Allied toPP. subrufa, Walker, in stature, breadth of apical limbus of the tegmina and wings, and the form of the thorax, but the frons is more obtuse, much less prominent and the coloration and marking very distinct. Vertex more than twice as broad as the transverse cye; ocelli almost thrico as distant from each other as from the eyes: frons occupying a little more than one-third of the face: thorax gradually dilated from the base to a distance beyond the middle, thence rounded and abruptly narrowed: costa moderately dilated, subcostal vein and costa contiguous throughout their entire length : seventh apical area of the tegmina shorter than the eighth : apical limbus of tegmina and wings of equal breadth, that of the tegmina colourless: opereula somewhat longer than their greatest breadth, yellow-greyish, infuscate at the base (S'tål).

O5. Platypledra andamana, Distant.

J. A. S. B. liii, (2), p. 214, no. 8.

†. Tawny pubescent : face moderately convex, transversely furrowed, with a deep central longitudinal furrow; lnteons with two short black basal lines on each side of the vertex : a narrow black fascia, extending from eye to eye immediately in front of the ocelli : eyes brilliant, castaneous, broally pilose behind : pronotum deeply furrowed with frontal edge and two small fovex, placed close together near the middle of the hind border, piceous : mesonotum with two large obconical spots extending backwards from the fore border midway between which there is a discal dart-shaped mark and two dots wide apart near the hind border, black: there are also two other somewhat obscure black marks sitnate on the fore border on the outer sides of the large obconical spots : metathoracic cross with its fore borders piceous: abdomen above with the segmental sutures black, clothed with a luteous pubescenec; anal append- 
age piceous, castaneons. Underside with legs ochraceous : rostrum extending to the second abdominal segment; its tip, two spots on the sixth abdominal segment, knees, and tarsi piceous: tegmina dark brown with pale semi-opaque markings, especially on tho apical half. Basal third thickly covered with pale pubescence and containing five dark-brown spots, of which the most prominent are two which are subcostal, situate beyond the middle of this space, and a third one below the basal of those two spots. Remainder of tegmina less pubescent with a number of whitish spots, of which the most prominent are a transverse row stretching across from near the costa to the inner border, immediately beyond the basal third pubescent space; another more waved row beyond the middle, confluent near the costa, where they are very visible below : a subapical marginal row of five whitish oblong spots, arranged on the veins of which the apical ends are dull brown; and an outer marginal row of six dark-brown spots, also arranged on the veins and of which the lowest is the largest; a dull whitish fusiform spot on the inner angle which is very distinct on the underside: wings eastaneous with a dark brown marginal border and some suffused dark-brown discal streaks extending across the wings (Distant).

\section{C6. Platypleura nicobarica, Butler.}

J. A. S. B liii, (2), p. 233.

Allied to $P$. fulvigera, Walker, from the Philippines, but larger, with tegmina longer; the whole of the spots crossing the coriaceous area, testaceons; those crussing its apex, smaller: the blackish transverse spots considerably smaller: the wings longer, the subapical, transverse, fasciolæ replaced by $3-\mathrm{t}$ decreasing longitudinal fulvous streaks : pronotum considerably broader, its lateral angles more oblique and therefore more prominent (Butler). Body long, 21 : exp. teg. 77 millims.

\section{O7. Platypledra basialba, Walker.}

J. A. S. B. liii, (2), p. 214, no. 10.

§. Bodly yellow, whitish pubescent, whitish pulverulous beneath: band in front and behind on the frons, also a stripe of short bands on each side, slender bands on the genæ, bands on the antennæe and their tips, seven small marks on the pronotum, three stripes on the mesonotum of which the side pair are oblique and the middle one straight, widened on each side by the fore border, and a small spot on each side near the hind burder, black : eyes and antennæ tawny; ocelli red : a:xlomen black; drums, tip and hind borders of the segments yellow: legs ycllow, briefly whitish pubescent; tips of claws black: hind tibiæ 
with tawny spines; first femora with two small tecth beneath: tegmina colourless, white at the base above, brown at the base beneath ; from this brown hue a short tawny stripe proceeds along the hind border and communicates with an oblique brown band which erosses the tegmeu near its base : wings colourless, dark brown with a whitish outline for near half the surface from the base which is tawny; flaps dark brown; veins tawny; piceous at the tips of the tegmina.

\section{O 8. Plattpleura octoguttata, Fabricius.}

\section{J. A. S. B. liii, (2), p. 216, no. 13.}

Head pallid with two dull-black parallel bands, three ocelli in the middle of the upper dilated band, two dots and a pale spot in the middle of the lower : thorax anteriorly rufous, a broad pallid band in the middle, posteriorly dull black with a great trifurcate spot, testaceous : abdomen black : tegmina at the base black; at the middle with four, large white spots $3-1$; at the apex, hyaline: wings short, black, posterior mar'gin, white (Fabr.).

$\sigma^{7}$, \&. Testaceous-flavescent, whitisl scriccous: dise of thorax, testaceons : two bands on the head and spots on the scutellnm, black: anterior band on the head in front spotted yellow : tegmina vitreous, scarcely basal half fuscous; spot near the apex of the radial area and anterior band, whitish, opaque; anastomoses margined fuscous; small spots (sometimes wanting) arranged in two subapical rows, fuscous: wings black-fuscous, veins sanguineous towards the base; broad veinless limbus colourless, vitreous; head very broad (Stål).

\section{Platypleura sobrufa, Walker.}

J. A. S. B. liii, (2), p. 216, no. 14.

९. Body tarny : two stripes on the head of which the fore one forms a circlet on the face, a row of bands on each side of the face, tip of rostrum, the antennæ, two marks on each side of the scutellum, black : rostrum tawny reaching the hind coxæ : posterior lobe of the pronotum pale tawny, piceous; mesonotum with four black marks, side pair large and obconical, inner pair smaller and nearly round, a black dot behind each of the latter: posterior margins of the abdominal segments and the tip mostly black: legs tawny, claws paler with black tips; tegmina colourless with a broad white band one-third of the length from the base; the colourless part includes a brown band, its cross-veins are clouded with brown and there are two inperfect rows of brown dots on the tips of the longitudinal veins of the marginal areolets: 
wings brown, tawny at the loase with a broad, interrupted white band and a white spot at the tips; veins dark tawny, flaps brown.

Specimen from Nagar (Sind).

$$
\text { O 10. Platypleura bufo, Walker. }
$$

J A. S. B. liii, (2), p. 216, no. 15.

8. Body tawny: two irregular bands on the head of which tho hinder one passes over the region of the occlli, tip of rostrum, the antenna, and median mark on pronotum, black : rostrum tawny reaching the posterior margin of the drums: posterior lobe of pronotnm pale tawny, ferruginous: mesonotum and abdomen ferruginous, the latter tawny at the tip and beneath : legs tawny, tips of elaws, black; first femora armed with two very short and blunt tawny teeth: wings very slightly tinged tawny, but tawny towards the base and bright tawny along the costal margin; veins tawny, darker towards the tips; transverse veins darker.

\section{11. Platypleura cervina, Walker.}

J. A. S. B. 1iii, (2), p. 217, no. 16.

+ . Body and rostrum pale buff; tip of the latter black, reaching the lind coxæ: antennæ piceous, buff at the base : legs pale buff; claws black, tawny towards the base; first femora with small teeth; hind tibir with buff spines having black tips : tegmina and wings whitish, veins yellow, the former buff along the costal margin; transverse veins clouded brown and a row of brown dots on the tips of the longitudinal veins of the apical areas.

\section{O 12. Platypleura hilipa, Walker.}

Platypleura hilpa, Walker, List Hom. B. M. i, p. 6 (1850); Batler, Cist. Ent. i, p. 185 (1874).

O Precilopsaltria hilpa, Stål, Berlin Ent. Zeitschr. x, p. 168 (1866).

O Platypleura fenestrata, Uhler, Proc. Acad. N. S. Phil., p. 282 (1861).

Body in $\delta$, tawny and in 8 , dark tawny : a broad irregular band across the vertex, bands on the face, the rostrum, the antennæ, sides of the posterior lobe of the pronotum, four broad obconical stripes on the mesonotum of which the inner pair are not more than half the length of the outer pair and between these latter a conical stripe and behind them five spots of which two on each side of the middle one which is angular and joins the conical stripe above mentioned, parts of the pectus and the abdomen, black: abdomen at the tip beneath and opercula and drums in the $\delta$, tawny; the opercula rather large: legs very dark tawny, claws black towards the tips, first femora not spinose : tegmina and wings in $\sigma^{\pi}$ 
paler than in $\$$, the former nearly colourless, dark tawny towards the base with four broad irregular brown bands and along the hind border two connected rows of brown spots: wings dull tawny with two brown bands, the inner one broader than the other but not extending more than half across the wing; flaps tawny (Wall.) Long, 21 ; teg., 67 millims. Reported from China.

\section{D13. Platypleura hyalinolimbata, Signoret.}

Platypleura hyalinolimbata, Sign., Bull. S. E. F. (6 sér.), i, p. xlii (1881).

Close to $P$. repanda, Linn., from which it differs in having the wings entirely of a velvety blackish brown, bordered by a broad hyaline limbus, veins of a distinct yellow: tegmina with the flattened marginal space between the side and the veins broader than in $P$. repanda; the expansion of the pronotum is concave and sinuated below, whilst in $P$. repanda it is convex (Sign.).

Reported from China.

\section{Platypleura repanda, Linnæus.}

O Cicada repanda, Linn., Syst. Nat. i (2) p. 707 (1766): Mas. Lud. Ulr. p. 159 (176t): Gmelin ed. Syst. Nat. i (3) p. 2097 (1782): De Géer, Mém. iii, p. 209, t. 33, f. 1 (1773): Olivier, Enc. Méth., V, p. 754 (1790): Germar, Thon's Arch. ii, fasc. 2, p. 220 (1830); Silb., Rev. Ent. ii, p. 78 (1834) : Guérin in Tigny Hist. Ins. vi, p. 189 (1830).

O Tettigonia repanda, Fabricins, Spec. Ins. ii, p. 321 (1781); Mant. Ins. ii, p. 267 (1787); Ent. Syst. iv, p. 23 (1798); Syst. Rhyng. p. 41 (1803).

Fidicina ? repanda, Walker, List Hom. B. M. ii, p. 90 (1851).

Platypleura? repanda, Walker, 1. c. Suppt. p. 13 (1858).

Tawny or yellowish brown; a black line and several small black patches on the thorax: opercula very large: abdomen black above: tegmina and wings tawny, transparent along the posterior margin near which is a series of transparent oval patches; tegmina have a like pateh on the exterior border and a waved transverse line, brown in the middle. Body long, 27 millims.

Reported from India.

$$
\text { OGenus TACUA, Amyot \& Serville. }
$$

\section{J. A. S. B. liii, (2), p. 217.}

Head broad, as broad as the thorax, triangular, with a longitudinal groove in the middle of the frons: eyes stout, prominulous: entiro lateral margins of thorax somewhat flattened out, anterior angles rounded, tegmina and wings entirely opaque: abdomen stout, tumid; opercula in $\delta$ very large, reaching at least the middle of the abdomen (A.\& S.). 
? 15. TACUA SPECIOSA, Illiger.

J. A. S. B. liii, (2), p. 217 , no. 17.

Black: pronotum with a narrow border anteriorly and a broad posterior band yellow with a greenish tinge, posterior margin of mesonotal cruciform elevation and two spots confluent with the margin orangeyellow: abdomen black, 5-7 segments yellow above with a greenish tinge and with a rounded black spot on the fifth segment: tegmina black or brownish olive with a dark green tinge, veins sanguineous: wings black with a broad sordid whitish limbus : feet black.

\section{oGenus Tosena, Amyot \& Serville.}

J. A. S. B. liii, (2), p. 217.

Head broad, triangular; frons very tumid without a longitudinal groove in the middle: eyes stont, prominulous: lateral margins of thorax very narrowly somewhat dilated, forming a tooth before the middle: the tegmina and wings entirely opaque with a weak, elevated, transverse line in the middle of each tegmen: abdomen stout, inflated; opercula as inOL'ucua (A. S. S.).

\section{o 16. Tosena melanoptera, White:}

J. A. S. B. liii, (2), p. 217 , no. 18.

In size and colour resembleg T. fasciata, Fabr. (reported from Javil) but in the latter, the veins of both tegmina and wings are of a very clear ferruginons colonr, the band is obscure yellow, there is a ferruginous line (sometimes interrupted) on the front of the clypens, the anterior margin of the pronotum has four small ferruginous spots and the tips of the femora are yellow. In $\checkmark T$. melanoptera, White, the veins of the tegmina and wings are nearly entirely black, the band on the tegmina is whiter and generally broader than in ${ }^{\circ} T$. fasciata, the clypeus is entirely black, there are no spots on the anterior margin of the pronotum, the yellow marks ahove the antenuo are smaller and the legs are of an uniform black (White).

\section{Tosena medresiana, Westwood.}

J. A. S. B. liii, (2), p. 217 , no. 19.

Black: posterior margin of pronotum, yellow: mesonotum postoriorly on both sides with an oblong, ferrnginous spot: metanotum nargined fulvous: tegmina black fuscous, veins black: wings broadly testaceons: anal area and slender apical margin, fuscous; veins black (Westwood). 
o 18. Tosena albata, Distant.

J. A. S. B. liii, (2), p. 217 , no. 20.

General colour and markings of T. melanoptera, White, but tegmina with five longitudinal whitish fascir situate between the veins commeneing near the base, two of which amalgamate with the broad median transverse band, and a subapical row of five irregular longitudinal fascir of the same colour, the first of which is placed at about one-third the length of the outer border from the apical point of the tegmina, and the last is fused into the median band near the inner margin. Wings as in T. melanoptera, but with a submarginal row of nine whitish fasciø commencing near the costa, of which the seventh and ninth are largest, the last very much so; two-thirds of the outer border narrowly edged with the same colour (Distant).

O 19. Tosena splendida, Distant.

J. A. S. B. liii, (2), p. 217 , no. 21.

or Body black: face with the lateral borders dull reddish, with a well-prononneed, central, longitudinal impression; transversely costate, with the int?rstices wide and irregularly punctale: eyes prominent, luteous and fringed behind with long hairs, pronotum decply furrowed, much as in T. melanoptera, White, with four large lutcous spots; two on the disc, sub-oval, converging from immediately behind the eyes towards each other, through two-thirds of the width of the pronotmm, their bases widened and separated by a space of about two millimitres; the other two somewhat larger aud much more irregular, occupying the posterior latcral angles; mesonotum very sparingly pilose (exeept near the lateral borders, where the hairs are much longer and more regularly abundant) and with two subcordate luteous spots on the dise, parallel with the pronotal central spots, and, like them, converging towards cach other at base: metanotum with two small luteons spots at the base, very indistinct in $\delta$, but clearly exhibited in $q$ : abdomen above pilose : rostrum black, with a small luteous spot near the base, in length just reaching the posterior coxæ. Body beneath and legs pilose; femorn with a wide contral, rufous band, fore-femoral spines apparently well developed: drums of the usual generic size, but situated close together, and divided by a very slight emargination bchind : abdomen with a longitıdinal discal row of sub-triangular reddish markings, the bases of which are situate on the posterior borders of abdominal segment. Tegmina and wings, where not obscured by darker markings, transparent, exhibiting varied opaline lustre, which in some lights is found to be varied with a close and regular scries of transverse darker strix: 
tegmina at base narrowly dark fuscous : costal area fuscous for rather more than half its length, veins and veinlets bright luteous, and for two-thirds the length of the tegmina, bordered on each side with fuscous : the apical border is also fuscous, very broadly so at the apex, and narrowing towards the inner margin, containing a sub-marginal row of pale luteous spots, which are the outer terminations of an equal number of narrow transverse linear, pale luteous striæ: claval area greenish: wings pale greenish for nearly two-thirds their area from the base, remaining portion shining fuscous, enclosing a sub-marginal row of palo opaline spots, of which the largest is sub-costal and irregular in shape, being somewhat sub-quadrate, hollowed out externally, and produced at the base towards the onter edge: veins and veinlets pale luteous, in some places tinged with green.

f. Differs principally from the $\delta$ in having all the colour markings intensified, the tegminal row of sub-marginal spots, which are luteons in the $\hat{\sigma}$ being pale opaline in the $q$ : the abdomen is more thickly clothed with pilosity and the rostrum is somewhat shorter in length than in the $\sigma^{2}$. (Distant).

ธ. Differs from the others in its paler coloration and more transparent appearance but the last peculiarity is shadowed in $P^{T}$. albuta, Dist. whilst the pronotal and mesonotal spots which ally it tooficeanct may be seen indicated on the pronotum of $\boldsymbol{O}_{\Gamma}$. melanoptera, White in which the two discal spots are jointly reeognizable whilst the broad pronotal lute' ous band of that species appears only as two angular spots in $T$. splentida.

\section{Genus Huechys, Amyot \& Serville.}

\section{J. A. S. B. liii, (2), p. 218.}

Body slender: head small, triangular, as broad as the pronotum; frons angular, slightlly compressed on each side, furnished with a distinet abbreviated longitudiual groove: eyes stont, slightly prominulons : the lateral margins of the thorax not dilated nuless anteriorly and not dentated: tegmina entirely opaque, ulnar veins distant at the base: abdomen elongate (A. S. S., Stål).

\section{Huechys philemata, Fabricius.}

J. A. S. B. liii, (2), p. 218, no. 22.

Black: frons, scutellum on both sides and the abdomen, sanguine-

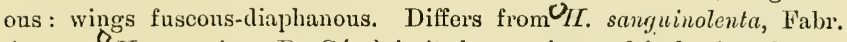
(same as II. sanguinea, De Géer) in its larger size, and in having the red frons immaculate; scutellum red; and dorsal streak, black : tegmina dull 
black not piceous and the wings smoky-diaphanous (Fubr.) Head thorax and fect, black; entire frons, two largo patches on the mesonotum and the abdomen, red : tegmina black, tip sordid white : wings smoky (A. S. S.)

\section{O21. Huechis sangunea, De Géer.}

J. A. S. B. liii, (2), p. 218, no. 23.

Head, thorax, pectns and feet, black, shining : frons, rounded, red : entire abdomen red: thorax with two large patches in the shape of elevated plates, red, of the colour of sealing-wax: eyes and oviduct in the $q$, brown : tegmina, elongate, somewhat broad, of a very obscure brown approaching black; longitndinal veins black, distinct: wings transparent of a brownish tint, veins black: ocelli three, palo red: antennæ short, setiform, situate on a much stonter cylindrical part: tegmina longer than the abdomen, wings a little shorter (De Géer).

Head black: frons rufous, a longitudinal line and the rostrum, black: thorax glabrous, black; a rounded spot on both siles, red: abdomen red : tegmina and wings obscurely fuscous immaculate: feet black ${ }^{(I I}$. sanguinolenta, Fabr.). Black, frous sanguineous, anteriorly black: two spots on the mesonotum and the abdomen: tegmina and wings, white; veins black $($ II. incarnata, Germar). This species is reported from India and Germar remarks that it may be a variety of C. sanguinolenta, Fabr. from which, however, it differs in the white, black veined, tegmina, having the apical veins narrowly cinctured fuscous, and the white, black-veined wings broally margined fuscous. OH. Germari, Gúerin, is probably also only a variety of this (Mag. Zool. p. 78 ; t. 237, f.'2, 1839):-Black, frons sanguineous, anteriorly black: two spots in the mesonotum and the abclomen, red: tegmina white, reined black, apical veins narrowly cinctured fuscous: wings blackfuscous, posterior lobe subhyaline (Guérin). Reported from Java.

\section{- 22. Huechis stellata, Walker.}

Huechys stellata, Walker, Ins. Saund. Hom. p. 27 (1858).

Black : head with tro testaceous spots between the ejes : mesonotum with six testacous spots, four in the middle and two belind: tegmina with two broad, irregular, fawn-coloured bands which are connected on the costa, a middle interrupted white band consisting of three large spots which are partly enclosed by the second broad band; ten exterior white dots on as many areolets: wings with five white dots (Wallier). Body long, 31-2 : teg. 92 millims.

Reported from India. 


\section{23. Huechis PICta, Walker.}

Inuechys picta, Walker, Ins. Saund. Hom. p. 28 (1858).

$\delta$, o Black: head with two testaceous bands: pronotum with a testaceous band on the hind border which is broad in the $q$ and extends in the middle to the fore border : mesonotum with a testaceous border and with two testaceous stripes which are broader in the $q$ : abdomen red with a black clorsal stripe: tegmina blackish, with a testaceous discal spot near the base, an interrupted testaceous band and two exterior subcostal dots : in the of the discal spot is almost obsolete and there is only one dot: wings crimson, with black borders (IValker). Body long, 19-21; teg. 50-52 millims.

Reported from Assam, Java.

\section{O Genus Scieroptera, Stål.}

J. A. S. B. liii, (2), p. 220.

Head scarcely narrower than the base of the thorax; frons slightly tumid occupying a little more than one-third of the breadth of the face, withont a longitudinal furrow; vertex more than twice broader than the eyes : the ocelli as far from the eyes as from each other or a little farther : rostrum not extended behind the intermediate coxø : first femora stout, spinose beneath; first tibio somewhat equal in length to the femora: six apical areas, ulnar veins contiguous at the base or united for a short space (Stål).

\section{C24. Scieroptera croces, Guérin.}

J. A. S. B. liii, (2), p. 220, no. 29.

Yellow : head obscure brunneous; spots red: thorax yellow; proand meso-notum each with two very large reddish-brown spots: abdomen croceous, more obsolete beneath; feet yellow; tibiw and tarsi, black: tegmina and wings hyaline, veins yellow, anterior veins with the membrane close to the veins, pale yellow (Guérin).

\section{Scieroptera splendiddi 4 , Fabricius.}

J. A. S. B. liii, (2), p. 220 , no. 30.

Small : head black; eyes pale : thorax pale, with two large rounded black spots : scutellum black, margin pale : abdomen red: tegmina fuscons witl a very vivid golden reflection : first femora black, tibiø very stout, dentated, red : last pair of feet black, femora red (Fabr.). 


\section{OGenus Graptotettix, Stål.}

J. A. S. B. liii, (2), p. 221.

Vertex twice as broad as the eyes; frons tumid, prominulous, somewhat compressed; ocelli as far from each other as from the eyes: thorax narrowed forwards, at the apex a little broader than the head: rostrum extended scarcely beyond the intermediate coxæ : first femora spinose beneath; first tibir longer than the femora: tegmina with ten apical cells, ulnar veins distant at the base (Stal).

\section{Genus G Gana, Amyot \& Serville.}

J. A. S. B. liii, (2), p. 221.

Body elongate: head triangular, narrower than the base of tho thorax ; frons tumid, prominulous, rounded, not compressed at the sides, nor groored : pronotum not dilated : tegmina and wings entirely opaque, the former furnished with eight apical areas, the ulnar veins distant at the base (A. \& S., Stål).

\section{O26. G五ana sibrula, Stål.}

Gceana sibylla, Stål, Trans. Ent. Soc. (3 ser.) i. p. 576 (1863).

\& Black: tegmina somewhat olivaceous yellow from the baso scarcely to the middle: wings beyond the middle, lutescent. Stature of O G. maculata, Fabr.: frons very tumid : thorax anteriorly somewhat narrower than the head, sides parallel from the apex to the middle, thenco abruptly amplificd: the costa of the tegmina and tho subcostal vein rather distant from each other throughout their entire length, ulnar veins rather distant at the base; apical areas very long, the first, fourth and sixth of equal length: opercula somewhat triangular, rounded at the apex (Stål). Long 42 ; exp. teg., 112 millims.

Reported from Tringany.

\section{O27. Geana octonotata, Westwood.}

J. A. S. B. liii, (2), p. 221, No. 33.

Black: frontal and posterior band on the head and a posterior band on the pronotum and the mesonotum yellowish, the last with two irregular yellowish lines: abdomen sanguineous, basal segments spotted above with black in the middle: tegmina fuscons-blackish, each with four whitish spots and very fine red veins: wings sanguineous with black lines (Westw.). 


\section{O28. Geana festrta, Fabricius.}

J. A. S. B. liii, (2), p. 222 , no. 36 .

Antenna testaceous: head dull black, a spot on both sides in the ocular area, ferruginous : thorax dull black, anterior margin and broader posterior margin of the anterior lobe yellow and the posterior lobe striated yellow: abdomen dull black, immaculate: tegmina fulvous, veins whitish, a median band and the apex on both sides emitting a tooth like mark, dull black : wings white, dull black at the apex, with a large white spot: feet dull black (Fabr.).

\section{O 29. Grana solphurea, Hope.}

J. A. S. B. liii, (2), p. 223, no. 38.

Black: head and thorax spotted sulphureous: basal half of wings sulphureous (tegmina divided by an oblique blackish band), apices yellowish-fuscous, veins in the obscure parts black (IIope). The tegmina are broadly wrinkled and the drum covers in the $\delta$ are small, leaving the striated internal membrane broadly exposed.

The following scheme attempts to provide a rough differentiation of some of the genera of clear-winged Cicalce found in India based on Stål's analysis :-

A. Anterior margin of posterior part of the first dorsal segment of the abdomen in $\delta$ emitting a foliaceous lobe which cover's the whole or part of the tympana or is dilated forwards more or less towards the sides. Body oblong or somewhat elongate: first femora spinose or acutely dentate beneath : frons usually more or less convex.

B. (1) Thorax narrowed forwards, lateral margins very often armed with a small tooth before the middle: (2) basal cell of tegmina more than twice longer than broad: (3) interior ulnar area not or but very slightly amplified towards the apex: (4) the ulnar veins very close at the base or contiguous.

○I. Dundubia group. A and B above.

01. Leptopsaltria: genø internally near the apex at the base of the lores furnished with a tubercle or tumeseence : rostrum reaching a little behind the last pair of coxæ : interior ulnar area of the tegmina not or only very slightly narrowed towards the apex : first pair of tibio longer than the femora : tympana above covered by a very large lobe : opercula short: second and third ventral segments in $\delta$ with a lateral tuberele. The lead is narrower than the thorax and the frons is moderately convex.

02 . Dundubia : genæ without a tubercle: rostrum not or scarcely reaching the base of the last pair of coxæ: the opercula are long and 
extended beyond the middle of the venter. The frons is large, very convex and near the base is almost twice as broad as the anterior margin of the lobes of the vertex.

o 3. Cosmopsaltria : genæ without a tubercle : rostrum extending beyond the base at least and very often beyond the apex of the last pair of coxas: the opercula are long and extended behind the middle of the venter. The frons near the base is not or only somewhat broader than the apical margin of the lobes of the vertex.

O 4. Pomponia: genæ without a tubercle : rostrum and frons as in Cosmopsaltria : opercula short, somewhat transverse.

OII. Cicada group. A as above.

B. (1) The lateral margins of the thorax always without a distinet tooth: (2) basal cell of tegmina rarely (Cicaldatra) twicc longer than broad, very often broad: (3) the interior uluar area gradually distinetly amplificd towards the apex, seldom (Emathia) equally broad towards apex and base: (4) the ulnar veins distinctly (often very) distant at tho base.

01. Cryptotympana: first apical area extended more forwards than the second: the transverse vein closing the base of the second apieal area, very oblique: the space lying between the postcostal marginal vein and the postcostal ulnar ramus lincar and not broader towards tho apex: the basal cell of the tegmina somewhat (but rarely twice) longer than broad: tympana entirely hidden : metasternum elevated in the middle and furnished with a posterior process turning backwards.

02. Cicada: as in Cryptotympana, but the metasternum is not or is only a little elevated in the middle and there is no postcrior process. The elypens is truncated at the apex or somewhat sinuately truneated.

0 3. Cicudatra: as in Cicada, but the basal cell of the tegmina is twice longer than broad and the tympana are partly visible. The clypeus too is somewhat acuminated or a little rounded at the apex.

04. Emathia : the first and second apical areas are extended to an equal distance forwards, the second is, however, longer than the first, the interior basal angle of the first area and the exterior basal angle of the second area are both obtuse: the interior ulnar area is not amplified towards the apex of the tegrnina and is equally broad at base and apex : the thorax anteriorly is scarcely narrower than the head and is amplified at the base: the tympana are for a great part visible : opercula short : rostrum scarcely reaching the last pair of coxæ : first pair of femora spinose.

O III. Tibicen group.

Tympana entirely visible; the anterior margin of the sides of the posterior part of the first dorsal segment of the abdomen is not produced and does not send out forwards a lobe. 
O 1. Tibicen : ulnar veins distant towards the base, diverging from the base : first apical area of the tegmina produced further forwards than the second: costa and radial vein contiguous towards the apex; veinless limbus of tegmina and wings moderate.

O2. MLelampsalta: ulnar veins contiguous at the baso itself or united towards the base : eight apical areas: first and second apical areas of the tegmina equally long and equally extended forwards : space between the postcostal marginal vein and postcostal ulnar ramus, linear.

\section{Dundubia mannifera, Linn.}

J. A. S. B. liii, (2), p. 223, no. 39 : liv, (2), p. $116 .{ }^{\circ} D$. nigrimacula, Walker (List Hom. B. M. i, p. 63) reported from Java and D. sobria, Walker (1. o. p. 63) reported from Hongkong are local forms of this species.

Pale subolivaceous-virescent or flavescent: frons very tumid: the dorsum of the abdomen marked by fuscous lateral spots: opercula in $\delta$ elongate, contracted near the base, very broad behind the middle, rounded at the apex (Stål). Body large, testaceous, immaculate: tegmina obscurely whitish, immaculate, costa black: opercula elongate, almost as long as the body, arched, testaceous, armed at the base with a robust, acute, incumbent spine (Fabr.). Head, eyes, and part of thorax, also the abdomen, of a light brown above; the rest of the body greenish : tegmina and wings transparent, greenish, spotless : opercula very large, almost as long as the abdomen (Olivier).

\section{Dundubia microdon, Walker.}

J. A. S. B. liii, (2), p. 224, no. 40.

f Body black: head with a tawny and green stripe in front and with an irregular green circlet on each side of the ocelli : face above with a short yellow stripe and with yellow bands in front: rostrum tawny, tip black, reaching the hind coxæ: antennæ black: pronotum green, with four slightly waved black stripes, outer pair very short, furrows black; posterior lobe green widened and slightly angular on each side in front of which is a very small tooth: mesonotum with four green stripes, the outer pair much longer than the inner pair, a green dot near each side which like the hind border is green : pectus tawny : abdomen black, brown beneath, posterior margins of the segments green : [drums black; opercula dull green, blackish towards the tips, tapering, very long, not far apart, more than half the length of the abdomen ?]: legs tawny; femora striated black : fore-tibiæ, feet, and the tips of the other tibiæ, black ; fore-femora with three black teeth of which two are long and one very small; a tawny band on the intermediate feet: wings 
colourless, green at the base ; the first and second transverse veins clonded brown; a row of pale brown spots on the tips of the longitudinal reins of the apieal areas; veins black; flaps with an opaline lustre.

\section{Dundubia vibrans, Walker.}

J.A. S. B. liii, (2), p. 224 : liv, (2), p. 116.

f Body pale tawny, rather long : head a little narrower than the pronotum, with an irregular and interrupted black band; face with black bands on each side; rostrum tawny, tip black reaching the hind eoxæ: eyes prominulous: antennæ black: pronotum broadest near the base of the tegmen, with four erooked black streaks, the outer pair short, the sutures also blackish, posterior lobe widened with two large blaek spots above the base of each tegmen, slightly notehed and with a moderate sized tooth on each side: mesonotum with fivo black stripes, a slight black streak in front between the two side pairs which are slightly oblique, the inner pair muels shorter than the outer pair which are almost interrupted : abdomen nearly linear, rather long, with a short black stripe at the base and on eaeh side of the tip, disc of the segments, piceous : drums tawny, closo; opercula, bright tawny, bordered with black, about half the length of the abdomen, narrow towards the base, willened towards the tips: legs pale tawny, elothed with paler hairs: tips of the tibir and of the feet, piceous; tips of the claws, black; fore femora with three teeth, two large and one small; posterior tibix with black spines : tegmina and wings colourless, pale tawny at the base; the tegmina slightly elouded with brown at the tips, the first and second transverse veins clouded with brown, an almost imperceptible brown streak on each apical area; veins partly black, partly tawny, the latter eolour prevailing most towards the base; flaps pale tawny at the base.

\section{O 33. Dundubia Nicomache, Walker.}

\section{J. A. S. B. liii, (2), p. 224, no. 44.}

$\delta$ Body black, nearly linear, tawny beneath : head with two zigzag marks behind the ocelli, a long angular stripe on each side between the eyes, a short stripe on the face, and on each side bands along the whole length, rostrum (tip excepted), lateral stripe, and four large oblique spots on anterior lobe of pronotum, the posterior lobe, and 3-4 irregular streaks on the mesonotum which vary in length and breadth, tawny : tip of rostrum which reaches beyond the hind coxæ, antennæ, siekle-shaped spots on the tawny spots of the anterior lobe of the pronotum, and three large spots near the base of each tegmen, and the abdomen, piceous: drums tawny, close ; opercula tawny obconical, very large, a little apart, 
more than two-thirds the length of the abdomon : posterior margins of the abdominal segments and the underside, tawny, tip piceous: legs tawny; feet ferruginous, claws black, ferruginous towards the base first femora with three tawny teeth, one very small : tegmina colourless, long, narrow, costal margin tawny; veins tawny witl two black bands across the disc beneath the stigma, black towards the tips, marked with black at the base; fore-flaps and hind flaps at the base and for a space along the hind border, pale tawny with a brownish tinge.

\section{D34. Dundubia tigrina, Walker.}

J. A. S. B. liii, (2), p. 224, no. 45.

o Body tawny, nearly linear, pale sericeous: head with a slight ferruginous tinge above : vertex with four black stripes, the middlo pair contiguous, partly united between the ocelli, side pair nearly round on proceeding from the base of the antennæ, thence narrower and slightly curved : a black band on each side of the face; rostrum tawny, tip black, extending a little behind the hind coxæ: antennm black: four black stripes on the anterior lobe of the pronotum of which the median pair slightly eonverge from the fore to the hind border, the outer pair are more oblique, posterior lobe very narrow in the middle with a black spot: mesonotum with five slender black stripes, the median entire, inner pair much and outer pair slightly interrupted: abdomen ferruginous above; posterior margins of the segments, piceous; beneath tawny, piceous at the base and tip: drums tawny, close; opercula black, small, far apart, outer margin tawny : legs tawny; femora striped black; tips of the tibiæ, piceons; claws black, ferruginous at the base ; fore and middle feet black, last pair ferruginons, first femora with three black tecth, one small : tegmina colourless, long, narrow; costal margin bright ferruginous as far as the stigma, thence to the tip, piceous; veins black, ferruginous towards the base, the first and second transverse veins clouded brown, a row of brown spots along the tips of the veins of the apical areas, all indistinct except first and second; fore flaps grey, hind flaps grey at the base and for a distance along the hind border.

\section{35. Dundubia (?) maculipes, Walker,}

J. A. S. B. liii, (2), p. 224, no. 46.

o Body tawny, whitish pubescent: two interrupted black bands across the vertex; furrows on face, black : rostrum pale tawny, tip black, reaching far beyond the hind coxæ: two black stripes on the anterior lobe of the pronutum, its sides and the furrows also blackish : mesonotum 
with two U-shaped marks and behind each a dot and on each side an oblique stripe, all black : abdomen with four rows of black spots, two in the middle and one on each side; posterior margins of the segments and the tip, partly black: drums small, blackish, tymbals white; opercula large, pale tawny, slightly overlapping, rather less than half the length of the abdomen : legs pale tawny, with a piceous band near the tip of each femur and tibia, the latter has a similar band near the base : feet tawny, piceous at the base, black towards the tips; femora streaked with black and with one black and one tawny tooth : tegmina colourless, pale tawny and marked black at the base, costal margin green; veins green, black towards the tip; transverse veins black, strongly marked and 1-4 clouded brown; a row of small brown spots near the tips of the longitudinal veins of the apical areas: hind flaps pale brownish, tawny towards the base and for a distance along the lind border.

O 36. Dundubia (?) samia, Walker.

J. A. S. B. liii, (2), p. 225 , no. 47.

$\delta$ Body green, tinged here and there with tawny: ocellar area piceous and a piceous streak on each side along the eye : rostrum tawny, tip black, reaching beyond tho hind coxæ : antennæ tawny : a pale streak slightly widened in front and behind on the anterior lowe of the pronotum and a piceous spot on each side : mesonotum ferruginous with some green marks, of which there is a large angular spot in the middle, on each side a forked mark, behind which there is a curved mark, and nearer each side, a slight streak : abdomen tawny, darker at the tip, paler beneath : drums tawny, small ; opercula pale-green, small, far apart: legs tawny; tips of the claws, black; femora with three teeth, one very small : tegmina colourless, costal margin green, tawny beyond the stigma; veins green, with a few black bands, tawny towards the tips; transverse veins clouded pale brown; a row of pale brown spots near the tips of the longitudinal veins of the apical areas : fore-flaps and the hind flaps between the middle-veins and the fore-border, brown.

\section{37. Dundubia (?) singularis, Walker.}

J. A. S. B. liii, (2), p. 225 , no. 48.

\& Testaceous, slender, partly green, very pale beneath : interocellar space and a dot on each side of the head in front and two dots near the border of the pronotum, black: mesonotum with an oblique green stripe on each side : abdomen with four rows of triangular, brown, spots : opercula small : tegmina and wings vitreous, with testaceous streaks between the apical anastomoses and the border, veins green or testaceous: teg- 
rnina narrow with the transverse veins and the forks of the longitudinal veins, clouded testaccous; a testaceous spot at the tip of each marginal vein communicating with a slight testaceous streak on each apical area a testaceous dot on the hind side of the third ulnar area with distinct indications of two transverse veins one joining the fifth anastomosis and the other ending on the front areola near the base of the second ulnar area ; a few minute testaceous dots on some of the marginal and discoidal veins.

\section{Dundubia ochracea, Walker.}

Fidicina ochracea, Walker, List Hom. B. M. i, p. 99 (1850).

Cicada ferrifera, Walker, l. c. p. 115 (1850).

Dundubia fasciceps, Stål, Ofvers. K. V.-A. Förh. p. 242 (1854) ; p. 481 (1862).

\& Sordid yellow; intraocular apical band on the head, blackish: tegmina more than half longer than the abdomen, whitish-hyaline, veins flavescent: below with feet yellowish-white: opereula one-half shorter than the abdomen, subparallel, rounded at the apex (Stal). Body long, 26 millims.

Reported from China: the Indian Museum possesses a specimen.

O 39. Dundubia radha, Distant.

J. A. S. B. liii, (2), p. 225 , no. 49.

б Body above pale castaneous: head with the area of the ocelli black; pronotum with the lateral and posterior margins and a very narrow anterior margin, ochraceous, the last is inwardly margined by two small, transverse, linear, black spots and the posterior margin has also a very narrow discal inner border of the same colour : mesonotum with a large median, obconical spot on the anterior margin, with a very indistinct median line and with the lateral margins black, outwardly marked with ochraceous; five indistinct basal spots, three within the anterior angle of the cruciform elevation and one on each side of the same: abdomen rather darker in colour with the segmental sutures piceous. Underside of the body concolorous, opercula dull ochraceous : tegmina with the costal membrane and claval area dull ochraceous: wings with the base narrowly of the same colour. The body is much elongated, the head including the eyes, a little narrower than the base of the pronotum; the face is prominently convex, faintly longitudinally furrowed and transversely striated: the rostrum reaches the middle of the posterior coxæ: the opercula are very long, reaching the penultimate abdominal segment, they are abruptly narrowed on the first abdominal segment, then gradually amplified and rounded on each side, maximum width being at the junction of the second and third abdomi- 
nal segments from whence they are gradually narrowed to the apex which is obtusely rounded (Distant).

\section{Dundubia tripurasura, Distant.}

J. A. S. B. liii, (2), p. 225, no. 50.

ơ Head, pronotum, and mesonotum ochraceous: frons with a triangular black spot near the base, and transverse black striø which do not meet in the middle, vertex with two large oblique and irregular black fascir on the disc, and a large irregular black spot on the inner margin of the eyes : pronotum with two median longitudinal black fas. ciæ, and three oblique black striæ on each side, the outer one submarginal and somewhat rounded: mesonotum with a large median clavate spot, of which the apex terminates on the anterior margin, bordered on each side by a subconical spot, followed by a small triangnlar one, and a wide submarginal fascia, black: abdomen dull sanguineous, with a series of diseal segmental black fascio (these are much larger in some specimens and subeonfluent) and a lateral segmental row of irregular black spots. Body beneath with the sternum ochraccous, covered with greyish pubeseence : abdomen dull sanguineous; opercula pale sanguineous; legs ochraceous : tegmina and wings pale hyaline. Frons very prominent and convex; head, including eyes, narrower than the base of the pronotum, subequal to the mesonotum in width: opercula subtriangular, well separated at the base, gradually becoming more divergent, and narrowing to the apex, which is obtuse, and almost reaches tho apex of the fourth abdominal segment: anterior femorn armed with three spines; two moderately large and ochraceous; apical one small and black; posterior tibiæ with three black spines on the inner side near the apex, and two smaller and wider apart on the margin (Distant).

\section{O 41. Dundubia nagarasingna, Distant.}

J. A. S. B. liii, (2), p. 225, no. 51.

$\delta$ Body above castaneous : head with the middle of the frons and an oblique fascia on each side of the ocelli, ochraceous : pronotum with a median band and lateral and posterior margins, ochraceous : mesonotum with two anterior median obconical spots denoted by black margins; margins of basal cruciform elevation, ochraceous : abdomen with the basal half sparingly clothed with greyish pile, the apical half much more densely so, and with a broad lateral fascia of greyish pile on each side: body beneath, with the sternum, legs, and opercula, pale ochraceous; abdomen pale castaneous. Tegmina and wings pale hyaline; costal membrane of tegmina ochraceous: head broad, including the 
eyes subequal in wilth to the base of the pronotum, and wider than the mesonotum; the face is very tumid, the middle longitudinally sulcated for half the length, and the sides transversely striated; rostrum reaching the apex of the posterior coxw ; opercula long, reaching the base of the last abdominal segment, narrowest and with the edges concave from base to the commencement of the second abdominal segment, from which they are somewhat abruptly widened with the edges convex and the apex somewhat narrower and rounded: anterior femora with two long ochraceous spines; posterior tibiæ with two long black spines, somewhat close together on the inner margin near the apex and two much wider apart on the outer margin (Distant).

\section{42. Dundubia terpsichore, Walker.}

\section{J. A. S. B. liii, (2), p. 233, ne. 94 : liv, (2), p. 117.}

\& Body pale green, slightly tinged with tawny, slightly clothed with white shining down : a black dot on each side of tho ocelli : rostrum pale tawny, tip piceous, reaching a little beyond the intermediate coxø: antennæ tawny: mesonotum with a piceous dot on each side above the cross-ridge : two last segments of the abdomen above and tho oviduct, piceons: legs pale tawny tinged with green; claws black towards the tips; first femora with two tawny teeth of which one is small : tegmina and wings colonrless, tinged with brown towards the tips, costal margin of tegmina green, slightly spinose, middle part black; veins black, green towards the base, black along the hind border of the tegmina, ; flaps buff and tinged with red at the base and for some distauce along the hind border.

\section{6) 43. Dundubia (?) evanescens, Walker.}

Dundubia evanescens, Walker, Ins. Saund. Hom. p. 6 (1858).

o Pale testaceons, slender: head with a black band, and with the usual black marks in front: pronotum with two approximate black stripes and with two black spots on each side: mesonotum with nine black stripes which are more or less abbreviated hindward where there are two black dots: abdomen with six stripes of black spots; the second pair of stripes ineomplete : opercula nearly half the length of the abdo. men : tegmina and wings vitreous, veins pale testaceous; tegmina with the marginal veins clouded by brown stripes which successively decrease in length, first and second transverse veins clouded with brown, very oblique, third and fourth oppositely oblique, slightly curved or undulating: wings very slightly clouded with brown along the transverse marginal veinlets (Wallier). Body long, 21-23; teg., 51-55 millims. Reported from India. 
044. Dundubia (?) Guttigera, Walker.

Dundubia guttigera, Walker, J. Linn. S. Zool. i, p. 83 (1856).

Testaceous: head with three angular stripes and an elliptical ringlet in front and on each side of it transverse lines, two dorsal nearly parallel stripes on pronotum, five stripes on the mesonotum of which the inner pair are abbreviated and the outer pair are interrupted, black: opercula small, rounded: abdomen ferruginous: tegmina and wings vitreous, the former with a brown spot on each transverse veinlet and on the tip of each marginal vein (Waller). Body along, 23 ; exp. teg. 71 millims.

Reported from Malacca, Singapore.

\section{o Genus Melampsalta, Kolenati, Stål.}

J. A. S. B. liii, (2), p. 225.

Head somewhat as broad as the anterior breadth of the thorax; vertex about twice as broad as the eyes: frons slightly or moderately convex, furnished with a more or less distinct, median, longitudinal groove : thorax broader posteriorly than anteriorly, the lateral margins obtuse, rarely a little dilated : ulnar veins of the tegmina contiguous at the base or united towards the base : eight apical areas, basal cell quadrangular : last ventral segment in $\&$ very deeply and broadly emarginate at the apex : tympana entirely visible above: opercula small or moderate : first pair of femora beneath $3-4$ spinose (Stål).

\section{o Genus Cosmopsaltria, Stål.}

J. A. S. B. liii, (2), p. 226.

The subgenera founded by Stål (1. c.) are thus distinguished :-

a. Frons very tumid, seen from above distinctly produced before the juga: clypeus rounded at the apex or narrowly roundly subtruncated.

$b$. Thorax broad anteriorly, entire lateral margins distinctly amplified, ramus of the interior ulnar vein distinctly curved towards the base :-Platylomia, Stål (C. flavida, Guérin).

$b$ b. Thorax much narrowed anteriorly, lateral margins not or only very slightly amplified: ramus of the interior ulnar vein straight or slightly curved : Cosmopsaltria, Stål (O. spinosa, Fabr.)

a a. Frons-slightly convex, not or but very slightly prominulous bcfore the juga: last dorsal segment in $\delta$ acutely dentated on both sides at the apex : clypeus narrowly truncated or sinuately truncated at the apex : $\rightarrow$ Diceropyga, Stål (C. obtecta, Fabr.). 
45. Cosmopsaltria obtecta, Fabricius.

J. A. S. B. liii, (2), p. 226 , no. 54.

Head virescent with a black vertical eross and on this the usual ocelli : the thorax green, the anterior lobe with small impressed lines, the posterior lobe with five more distinct abbreviated lines: abdomen virescent, furnished beneath with opercula which are arched, elongated, cinereous and armed at the base with a robust, acute spine: feet virescent with black lines (Fabr.).

$\delta$ Weak olivaceous-virescent: an interior marginal spot bencath the middle of the lores; the extreme interior margin of the genæ at the frons; four transverse, lateral, subbasal lines on the frons terminated inwards by a longitudinal line and united, interior apical angle and median subapical spot on the juga; a narrow median band slightly verging forwards on both sides and spots on the vertex including the ocelli, two narrow median streaks very slightly diverging before tho middle posteriorly slightly areuated not extended behind the posterior transverse impression, a small median, lateral discoidal streak on both sides, a small oblong obliquely longitudinal spot behind the lateral oblique median impression, also a streak near the lateral margins of the thorax, three median longitudinal lines (the middle one near the apex of the scutellum the lateral ones abbreviated in the middle of the scutellum), all reaching the base, the lateral ones slightly converging backwards, four small basal spots situate towards the sides, an obliquely longitudinal line abbreviated on both sides, situate behind the exterior basal spot and two small spots placed behind the middle of the seutellum, an irregular spot on the first dorsal segment of the abdomen, two lines (one interior, the other exterior) also two spines on the first pair of femora, an abbreviated upper anterior line on the posterior femora and an indistinet band near the apex of the posterior tibiæ, blackish. A median band and lateral spot (sometimes very obsolete) on the dorsal segments of the abdomen, fuscous-testaceous: tegmina and wings somewhat sordidly vitreous: veins fuscous, olivaceous-virescent towards the base; the apex of the exterior uhar vein flavescent at the costa; the two exterior anastomoses with a fuscous limbus.

$\delta$ Apieal angles of the last dorsal anal segment produced in a long lobe, gradually acuminated, the lobes below and towards the apex fuscous, inferior anal segment obtusely emarginate at the apex : upercula about one-third shorter than the abdomen, beyond the middle towards the apex gradually, thence more abruptly narrowed, in wardly behind the middle rounded, ontwardly straight, rounded at the apex, olivaceousflavescent: second ventral segment armed at the apex in the middle of the sides with a much elevated tubercle. Head equal in breadth to tho 
posterior part of the thorax, anteriorly very obtusely rounded: frons seen from above truncated, scarcely prominulous before the juga, slightly convex, sides distinctly furrowed: thorax somewhat narrowed forwards beyond the middle, thence forming an angle prominulous in a minuto tooth, anteriorly more narrowed : tegmina extending beyond the abdomen by half their length; the first anastomosis rather oblique, interior uluar area gradually very slightly narrowed towards the apex, much obliquely truncated at the apex, interior apical angle obtuse, somewhat rounded: first pair of femora bi-spinose beneath (S'tål).

\section{Cosmopsaltria sita, Distant.}

\section{J. A. S. B. liii, (2), p. 226, no. 55.}

f Head, frons with a central fascin furcate anteriorly and an oblique spot on each side at the base; vertex with a large triangular spot inclosing the ocelli and an irregular longitudinal fascia near the inner margin of the eyes, black : pronotum with two central longitudinal fascir joined and rounded near posterior margin, widened and angulated near anterior margin, on each side of these is a small discal waved line and two oblique fascir near the lateral margins (the outer one submarginal and rounded) black: mesonotum with a central longitudinal fascia, on each side of which is a clavate, smaller and suboblique fascia, followed by two linear spots on the anterior margin and a discal waved irregular fascia on each side. Abdomen with the segments (excluding first) more or less piceous at the base and with a lateral segmental row of piceous spots : body beneath ochraceons and unicolorous. Tegmina and wings pale hyaline, the former with tho venation of the basal half, ochraceous, and of the apical half, fuscous; transverse veins at the base of the 2-3 apical areas, fuscous-ochraceous at the junction. The liead, including the eyes, is considerably narrower than the base of the pronotum, the face is only moderately convex, furrowed from beyond the middle, the sides distinctly striated (the face has also an oblong spot bordered with black at the base and the upper strix are also of that colour). Opercula reach the third abdominal segment, they are moderately truncate outwardly, widened and angulated inwardly (but not meeting) on the first abdominal segment and then diverging and narrowing to the apex which is obtuse and rounded; the inner margin is slightly convex : rostrum reaching a little beyond the last coxæ: anterior femora with two strong spines (Distant).

\section{47. Cosmopsaltria durga, Distant.}

J. A. S. B. liii, (2), p. 226, no. 56.

\& Head, pronotum, and mesonotum dull ochraceous : head with the following black markings ; an irregular spot on the frons, a large central 28 
fascia on the vertex, reaching from the anterior to the posterior margins, produced on each side in front, enclosing the ocelli ; a curved fascia a little before the inner margin of the eyes, and a subtriangular spot on the apex of the lateral margin: pronotum with the anterior margin (narrow), a central longitudinal fascia, bordered with black on each side, and a triangular fascia on each lateral margin, pale ochraceous; two narrow oblique fasciæ on each side, a narrow longitudinal fascia on each side of the disc, inner posterior, and inner and outer lateral margins, black : mesonotum with a clavate central longitudinal fascia, bounded on each side by a shorter, broader, and much angulated one, followed by an elongated spot and by a sublateral broad fascia, broken near the anterior margin, two rounded spots near the base, and two smaller ones on the anterior branches of the cruciform elevation at the base : abdo. men pale castaneons, disc piceous, gradually widening from the base to the apex, where it is wholly black. Underside of the body ochraceous and unspotted; a black spot on the inner margin of the eyes, anterior tibia and tarsi, apices of intermediate tibiæ and tarsi, and apex of the rostrum, piceous. Opercula pale greenish : tegmina and wings pale hyaline, transverse veins at the bases of the second and third apical areas, infuscated. Face broadly sulcated in the centre, and transversely striated (many of the striw black) ; rostrum passing the posterior coxæ, and reaching the inner angles of the opercula. Opercula reaching the second abdominal segment, the outer margins subparallel with the lateral abdominal margins, hipped and widest (but not meeting) near the bases of the femora, from thence diverging and gradually narrowing to the apex, which is obtusely angulated : anterior femora with two long and prominent teeth, and a shorter one near the apex. Posterior tibiæ with three inner and two outer long marginal spines (Distant).

\section{- 48. Cosmopsalitria oopaga, Distant.}

J. A. S. B. liii, (2), p. 227 , no. 58.

Head dull ochraceous : posterior lateral margins of the frons black; the two basal ocelli surrounded with black, which extends to the posterior margin : pro- and mesonotum pale olivaceous; pronotum with a central longitudinal ochraceous fascia, bordered with black, which is widest anteriorly, and rounded, with the black lines continuous posteriorly; mesonotum with two obconical spots, bordered with black on the anterior margin, followed by a small black spot, and an anterior lateral fascia ; a curved basal fascia and a small spot on each frontal side of the cruciform elevation, of the same colour: abdomen dull ochraceous, inclining to olivaceous, with the lateral side sparingly covered with greyish pubescence, and with an indistinct lateral segmental row of fus- 
cous sp ts. Un lerside of the b ody, pale ochraceous or olivaceous: tegmina and wings pale hyaline : the body is broad and somewhat depressed, the abdomen narrowing at the apex : the head, including the eyes, is narrower than the base of the pronotum, and but little wider than the mesonotum : the rostrum about reaches the apex of the first abdominal segment: the opercula, which almost reach the apex of the fourth abclominal segment, are situate on the lateral side of the abdomen, much wider apart at the base than at the apex; they are concavely narrowed on each side near the base, and are there widened and convex on each sicle to the apex, which is broad and rounded; the extreme apex beng on the outer margin. The face is tumid with a curved black fascia at the base, and a central longitudinal furrow; it is profoundly transversely striated, the interstices being rely broad (Distant).

\section{O 49. Cosmopsaltria flavida, Guérin.}

J. A. S. B. liii, (2), p. 227 , no. 60.

Yellow-virescent: head yellowish-green with a brown spot on each side of the labrum and in front and another blackish spot in the middle between the eyes which are red: the pronotum is broader behind, of tho same colour as the head, with a transverse groove rounded at the ends and two oblique grooves in front; the posterior margin after the groove is flat, wrinkled transversely, bordered brown, also two triangular spots placed in its midst and two lines on the anterior margin but not reaching the middle: mesonotum tumid, smooth, with two deep hollows on the posterior and lateral margins, emarginate behind ; above and at its junction with the pronotum are four angular brown spots, a longitudinal line and two arcuate spots on the dorsum and four rounced spots bchind, brown : abdomen yellowish-green, the middle slightly red and the posterior margin of the segments finely edged with black, covered with a silvery white pubescence. Tegmina and wings transparent, veins yellow and in some places, brown; a row of seven sinall round brown spots on the external margin of the tegmina (and fonr on the anastomoses) larger and deeper posteriorly: body beneath more yellowish than above with portions greenish: tip of rostrum black, reaching the posterior coxæ: opercula small, bordered outside with black: femora yellow (anterior pair excepted which have beneath two small spines and the tips, black); tibiro yellow with base and tip blackish; tarsi brown : oviduct \& orange yellow (Guérin).

\section{O 50. Leptopsaltria guttularis, Walker.}

\section{J. A. S. B. liii, (2), p. 227 , no. 61 .}

\& Testaceous varied with green, beneath mostly pale green : liead with a 4 -forked mark about the ocelli, two transverse streaks on each 30 
side, sutures on the face and three streaks on each side, black : a band in front on the pronotum also two stripes which approximate in the middle and three streaks on each side where there is an acute angle in front, a median stripe and five streaks on each side on the mesonotum, four spots on the pectus, and abdomeu partly beneath towards the tip, black : tegmina and wings vitreous, veins testaceous, black towards the tips; tegmina with a whitish stigma, tips and transverse veins and tips of the marginal veins clouded with brown.

\section{O 51. Leptopsaltria albigutta, Walker.}

Dundubia albigutta, Walker, J. Linn. S. Zool. i, p. 83 (1856).

Green, partly testaceous: two lines forming an angle, in front of the ocelli, borders of ocelli, a line on each side of the fore margin of the head, transverse lines along most of the ridges on each side of the frons, and two tubercles on each side of the abdomen beneath, blaek : opereula small rounded : tegmina and wings vitreons; the former slightly elouded brown at the tips ; a whitish spot on the costa at the tip of the first apical area; first and second transverse veins with brown spots (Wallier). Body long, 18-19; exp. teg. 67 millims.

Reported from Malacca, Singapore,

\section{Cosmopsaltria andersoni, Distant.}

Cosmopsaltria andersoni, A. M. N. H. (5 ser.) p. 170 (1883).

o. Head olivaceous; lateral margins of the frons, area of the ocelli and a small spot on each side of the same, black : pro- and mesonotum olivaceons, the former with a central, longitudinal, ochraceous band, bordered with black, widest anteriorly and compressed about the centre and with a small curved black line behind the eyes : mesonotum with two obconical spots bordered with black on the anterior margin, on each side of which is a small discal black streak and a curved black spot on each side of the base near the anterior angles of the cruciform elevation, which are also black: abdomen dull, dark ochraceous : underside of body pale ochraceous; annulation on the anterior femora near their apices, upper surfaces and apices of anterior tibim, bases and apices of intermediate and posterior tibiæ and tarsi, apex of rostrum, and apical portion of last abdominal segment, black : tegmina and wings pale hyaline, the first with the costal membrane and the basal portion of the venation, ochraeeous; the remaining portion of the venation more or less shaded and marked with the veins black or olivaceous, and with a black claval streak: wings with the veins black or olivaceous, outer claval margin and an inner claval streak fuscous. The body is broad and 
somewhat depressed, the abdomen above moderately pilose : the head, including the outer margins of the eyes, is subequal in width or a very little narrower than the base of the pronotum: the rostrum about reaches the middle of the first abdominal segment : the opercula are long, strongly compressed and sinuate near the base, and then widened and convex on each side, but narrowing at their apices which reach the base of the last abdominal segment: face swollen and tumid with a narrow median longitudinal groove and strong transverse striations, the interstices of which are very broad. Allied to $C$. oopaga, Distant, from which its smaller size and the greater length of the opercula at once distinguish it (Distant). Long, 32 ; exp. teg. 88 millims.

Reported from Mergui.

\section{Genus Pomponia, Stål.}

J. A. S. B. liii, (2), p. 228.

Stål distinguishes the subgenera Pomponia and Oncotympana thus :-

- Pomponia-Abdomen in 8 longer than the head, thorax and scutellum taken together, the first segment occupying the fifth or sixth part of the abdomen, posterior margin straight or somewhat rounded, the anterior lateral lobes moderate, not or very slightly convex, covering only a part of the tympana, space between these lobes broad or someO what so: last ventral segment acutely dentate on both sides at the apex. (P. fusca, Olivier).

$\sigma$ Oncotympana Abdomen in $\delta$ short, shorter or only as long as the head, thorax and scutellum taken together; first dorsal segment occupying abont one-third of the abdomen, posterior margin more or less distinctly sinuated; anterior lateral lobes very large, covering the entire tympana, convex, broader than the space lying between them: last dorsal segment in of obtusely rounded on both sides at the apex $(P$. pallidiventris, Stål).

O 53. Pomponia urania, Walker.

J. A. S. B. liii, (2), 228 , no. 62.

o Body somewhat fusiform, ferruginous, partly whitish pubescent : head and pronotum tinged with green : rostrum tawny, tip black, reaching beyond the posterior margins of the opercula : antennæ tawny: posterior lobe of the pronotum bright green, partly ferruginous along the fore border no tooth : mesonotum green on each side and at the tip, crossridge pale tawny : abdomen green, powdered white beneath, and at the base a short snow white band which forms two triangles: drums pale tawny, close ; opercula of moderate size slightly overlapping, full one- 
fourth of the leugth of the abdomen: legs tawny, tinged green; first femora with three tawny teeth, two large, one very small, claws black, tawny at the base: tegmina colourless, slightly tinged with tawny towards the tips, a row of pale brown spots along the tips of the longitudinal veins of the apical areas; first and second transverse veins clouded brown with traces of it on the others; costal margin green to the stigma, dark tawny thence to the tip; veins green, with black bands across the breadth beneath the brand, wholly black towards the tips : basal cellule, flaps at the base and for a space along the hind border,
tawny.

\section{Pomponia bindusara, Distant.}

J. A. S. B. liii, (2), p. 228 , no. 63.

o Body above pale ochraceous; head with the lateral margins of the front bordered with black striæ, and with two contiguous black spots on the disc; two oblique strix on the lateral margins of the vertex and the area of the ocelli black: pronotum with two central longitudinal fasciæ, narrowed, joined and rounded on the posterior margin, widely divergent and terminating on the anterior margin, a small curved fascia on each side of the disc and oblique striæ also, black : mesonotum with a central fascin, a shorter and more oblique one on each side, followed by an elongate spot on the anterior margin, and a loug, somewhat broken, submarginal fascia, black; two rounded spots in front of the cruciform elevation, and two smaller ones on the anterior branches of the same, also black: abdomen somewhat thickly covered with pale pubescence, with a series of diseal segmental markings, two large spots near the lateral margins of the third and fourth segments, and a lateral segmental row of small spots, black. Underside of the body pale ochraceous : apical dise of the abdomen, black: tegmina and wings pale hyaline; transverse veins, at the bases of the second and third apical areas, slightly infuscate : face convex : apical two-thirds with a narrow central furrow transversely striated, the striæ black near the middle. Rostrum slightly passing the posterior coxæ, its apex black: opercula small, posterior margins obtusely angulated, and reaching the base of the first abdominal segment, widened and obtusely angulated, but not meeting inwardly : posterior tibiæ with three inner and two outer marginal spines: anterior femora with two long and prominent spines (Distant).

\section{O 55. Pomponia kama, Distant.}

J. A. S. B. liii, (2), p. 228, No. 65.

\& Head, pronotum and mesonotum greenish: head with the lateral sides of the frons, black : vertex with two transverse lines on the lateral 
margins, somewhat connected inwardly by a short oblique fascia and the area of the ocelli, from which proceed two narrow fasein to the posterior margin, black : pronotum with a median, black, elavate fascia, of which the mildde is ochraceous, widest and much angulated at the anterior margin, narrowest and somewhat acutely pointer on the posterior margin ; an arcuated narrow fascia on each side of the dise; oblique striz pale fuscous; lateral submarginal striæ black, and an obliqute fuseous spot on the lateral margins; posterior margin narrowly edged with black: mesonotum with two large obconical spots margined with black, and a large $\wedge$ faseia in front of the anterior angles of the basal eruciform elevation : tympana pale greenish, fuscous anteriorly, and bright cretaceous-white near the lateral margins : abdomen castaneous, lateral margins of the basal segment bright cretaceons-white. Body beneath with the head, sternum, and opereula greenish; abdomen eastancous: legs grecnish ; spices of tibio and tarsi and tarsal claws, black : tegmina pale fuscous hyaline; anatomoses and apices of the lateral voins at the margin broadly infuscate, and a blackish spot near the termination of the radial, vein: wings pale hyaline: face broad, convex, the midllle blackish, and with a central longituclinal impression, and transverse striations: rostrum with the apex black, and just passing the posterior coxæ : opereula very short, not reaching the base of the first abdominal segment : abdomen beneath deeply furrowed at the lateral margins, the disc somewhat gibbous : head, including the eyes, narrower than the base of the pronotum, about equal to the base of the mesonotum (Distant).

\section{O 56. Pomponia madhava, Distant.}

J. A. S. B. liii, (2), p. 229 , no. 66.

ot Body pale greenish : abdomen with a lateral row of three large, oblong, spots, only denoted by their darker green margius, occupying the lateral sides of the first three segments; segmental incisures narrowly clark greenish : ocelli red; eyes fuscous: mesonotum with two very faint obeonical spots. Body beneath pale greenish: legs and rostrum pale ochraceous: tegmina and wings pale hyaline; the first with the costal membrane and the veins pale greenish: the head, iucluding tho eyes, is narrower than the base of the pronotum ; the face is broad and convex, with a broad central longitudinal impression an! strong transverse striations; the opercula are small, not reaching the apex of the metasternum; the second and third abdominal segments beneath are rounded, produced, and poiuted anteriorly ; the rostrum reaches the posterior coxæ (Distant). 
57. Pomponia linearis, Walker.

J. A. S. B. liii, (2), p. 228 , no. 64.

ð. Body tawny beneath: head and pronotum piceous, with indistinct tawny marks, chiefly along the sutures; face piceous towards the rostrum, which is tawny with a black tip that extends to the posterior margins of the opercula : antennæ black: pronotum with six pale tawny stripes which proceed from the fore border to the disc: pectus green : abdomen ferruginous, segmental incisures black: the tympana dark ferruginous ; opereula green, rather large, hardly apart : legs tawny ; fore femora with two sharp tawny teeth; tips of fect and of the claws black: tegmina with an indistinet tawny tinge, slightly coloured with green, pale brown and marked with black at the base, costal margin greenish, transverse veins clouded brown; a row of small brown spots on the tips of the longitudinal veins of the apical areas; veins with alternate black and pale yellow bands; veins of the wings tawny, trausverse veins darker; flaps pale brown at the base.

\section{O 58. Pomponia imperatoria, Westwood.}

\section{J. A. S. B. liii, '2) 229 , no. 67.}

Luteous-fulvous : head and dorsum of thorax with very many black spots varying in size and form; mesonotum with a trifid mark: sides of pronotum emarginate and angulate in the middle: abdomen brunneous, sides paler, a spot on both sides on each segment, black : wings yellowish hyaline, veins fulvous : subapical transverse veins on the tegmina, clouded fuscous, and seven spots towards the margin, fuscous (Westw.)

\section{O 59. Pomponia tigroides, Walker.}

D Dundubia tigroides, Walker, Ins. Sannd. p. 5 (1858).

Pomponia tigroides, Distant, J. A. S. B. xlviii, (2), p. 38 (1879) ; liii, (2), p. 229 (I884), no. 69 .

․ Green, partly testaceous : head with minute black marks in front and on each side and with a large black spot on the vertex: pronotum with sis black stripes; the inner pair dilated at each end, the middle pair oblique, the third pair marginal; a curved brown discal streak on eaeh side between the first and second pairs : mesonotum with five black stripes which are slightly dilated posteriorly, outer pair curved posteriorly, two black dots on the posterior margin : abdomen with a black lanceolate mark on each of the first and second segments, with black dots along each side and with a black subapical band : costa of tegmina green, luteous beyond the middle, stigma black with a pale band, vcins 
green, partly black, first and second transverse veins very slightly clouded with brown (Walker). Body long, 23 ; teg. 54 millinss.

Differs from $O_{D}$. tigrina, Walker, by the outward curve of the exterior stripes on the nesonotum, by the spots and band of the abdomen and by the first transverse vein of the tegmina, which is slightly obliquo outwards, whereas that of $D$. tigrina is very oblique inwards.

Reported from India, Tenasserim.

\section{O60. Pomponia expansa, Walker.}

Carineta expansa, Walker, Ins. Saund. Hom. p. 26 (1858); Signoret, B. 8. E. F. (6 sér.) i, p. xli (1881).

Pomponia expansn, Stål, Berlin Ent. Zeitschr, x, p. 171 (1866).

ð. Black, short, pilose, very broad : head with two green spots on tho vertex; frons with a green stripe and with lateral transverse testaceous streaks: pronotum with two angular green stripes in tho middle and with a curved stripe on each sille; borders testaceons-green with two black spots on each side: mesono tum with varions dorsal testaceous marks; borders green : abdomen blackish-brown; dorsal and ventral operculas testaceous, with dusky borilers, the latter very broad, about half the length of the abdomen : legs testaceous, striped with black: wings vitreous, veins tawny here and there green, partly bright pale green at the base: tegmina with a pale green stigma, a brown spot near the tip of each marginal vein ; transverse veins clouded with brown, first and second slightly oblique and curverl, first parted from the second by a little more than twice its lengtl, the third and fourth nearly straight (Walker). Body long, 27 ; teg., 96 millims.

Reported from India, China.

\section{O 61. Emathia mgrota, Stål.}

J. A. S. B. liii, (2), p. 229, no. 69.

§. Very pale olivaceons, sparingly greyish-sericeous : a median streak amplified forwards and posterior limbus of thorax, four triangular spots reaching the base of the scutellum (the median small, the lateral spots large), also the dorsum of the abdomen, subtestaceous : tegmina and wings, vitreous; veins pale olivaceous-virescent, fuscous towards the apex; a spot on the two exterior anastomoses and a subapical spot at the exterior margin of the tegmina, fuscous ; the first anastomosis of the wings margined with fuscous, the veinless margin inwards at the anal area and the anal area at the base, fuscous : streaks on the femora and apex of tibix fuscescent. In the $\sigma^{\prime}$, the opercula are small, oblique, oblong and the first ventral segment is triangularly elevated lotween the 36 
opercua. The head is scarcely broader than the apex of the thorax; the vertex searcely more than twice as broad as the eyes; frons prominulous. Ocelli somewhat more distant from each other than from tho eyes. Thorax either somewhat amplified forwards or with the sides parallel, abruptly amplified at the base. First pair of femora trispinose (Stål).

\section{O Genus Rustia, Stål.}

Mem. Afric. iv, p. 8 (1866).

Head as broad as the anterior lobe of the thorax, anterior margin deeply incised between the frons and the freely prominulous lobes of the vertex, lateral part which bears the somiglobose eyes turning somewhat upwards : rostrum short: ocelli twice as distant from each other as from the eyes; eyes remote from the base of the head : the part of the thorax lying before the transverse impression more than twice as long as the posterior part: tympana entirely visible; anterior margin of the sides of the first dorsal segment of the abdomen neither produced nor sending forwards a lohe; nhar veins of the tegmina distant at the base; wings with five apical areas: first pair of tibir not produced in a spine beyond the insertion of the tarsi (Stål).

\section{Rustia pedunculata, Stål.}

Rustia pedunculata, Stål, Berlin Ent. Zeitschr. x, p. 383 (1866).

․ Testaceous-flavescent: clypens, lores, genæ (except the ocular part), ocellar area, six streaks on the thorax (median pair and the intramarginal lateral pair narrow), five streaks on the scutellum (the median streak and lateral pair elongate), black-fuscous : the dorsum of the abdomen with obsolete fuscous streaks: tegmina and wings vitreous, veins fuscous, costa and the radial vein yellow-olivaceous, interrupted subapical band (which is dentated posteriorly) on the tegmina, fuscous: last dorsal segment of the abdomen, fuscous; an obsolete median streak and the sides, testaecons-llaveseent, the sides with a fuscons spot: last ventral segment very slightly and very broadly simnated at the apex. Vertex thriee as broad as the cyes : ocelli twice as distant from the eyes as from each other: lateral margins of the thorax parallel, abruptly amplified at the base: interior ulnar area of the tegmina slightly narrowed towards the apex, first apical area longer than the second, seventh and eighth apical areas of equal lengtlı, somewhat small : first femora 3-spinose, the subapical spine minute (Stril). Long, 13; exp. teg. 31 millims.

Reported from Cimbodia. 
UGenus Cicada, Linnæus, Stål.

J. A. S. B. lini, (2), p. 229.

This is one of the oldest names in the order and has suffered so many clianges by the creation of new genera that it would be unprofitable to trace back its history. Taking the changes of the last quarter of a century, we fing that in 1866 Stal addec foptopsaltria, Cosmopsaltria, and $\checkmark$ Pomponia to the Dundubia group. The Cicarla gromp incheling Piclicina was increased in 1861 (A. S. E. F. (4 sér.) i, p. 613) by Praltorla, Cryptotympana, OTympanoterpes, and Belymbria, and, in 186t, by Proarna. In 1862, Stål (Rio. Jan. Hem. p. 19) distributed the species of Cicala proper amongst the subgenera Cicada, OTaphura, $\mathcal{P}_{\text {Prnisa, }}{ }^{O}$ Calyria, and Prunasis. All of these were raised to the rank of genera in 1866 (Hem. Afric. iv, p. 8) and, excepting Cicada, were thrown into the Tibicen gronp. To the Cicalla group were added Menicopsaltria, Nosola, and Emathia, in 1866 ; and to thd Tibicen gronp, Tlenicotetti.x in 1858; Pyina, Stagira, Callipsaltria, and Tympanistria, in 1861; and Rustia and Beturia, in 1866. In 1870, Stål still further divided the species of his restricted Cicala in establishing the subgeneralChremistica, Macrotristia, "Cicala, and

Diceroprocta. I doubt much whether any of those Indian species which still bear the generic name 'Cicala really belong to that genus: if they do, they belong to the subgenus" Cicada, which has the sides of the thorax anteriorly without a lobe; the sides of the last dorsal segment in $\sigma^{*}$ posteriorly unarmed, very often produced in an acute tooth in the micldle; the sixth ventral segment in $q$ broally, angularly sinuated at the apex; and the interior ulnar vein straight or but slightly curved. This question can only be settled by an examination of the types.

\section{o 63. Cicada (?) ferruginea, Olivicr.}

J. A. S. B. liii, (2), p. 230, No. 74.

Entirely ferruginous, clouded brown : tegmina and wings of a deep colour, the posterior margins light and transparent (Olivier).

O64. Tibicen (?) auratus, Walker.

J. A. S. B. liii, (2), p. 230, no. 72.

б. Body black, densely tawny pubescent, pale tawny beneath : a band in front of the head, three spots in the ocellar area, face and rostrum, tawny: disc of face, tip of rostrum which reaches the intermediate coxø and the antennæ, black: anterior lobe of pronotum with the borders and a short stripe, behind which are two triangnlar spots resting on the hind border; posterior lobe and two stripes on the mesonotum amplified in the middle and its posterior margin, 
tawny: abdomen velrety black with patelies of golden hairs : [tympana uncovered, tawny, rather large ; opereula pale tawny, small, wide apart ?] : tip of abdomen tawny, with a horn of the same colour : legs yellow ; femora striated black; tips of the tibiæ and of the foet, black; claws black, tawny at the base; fore-femora with three robust black teeth ; fore-tibio mostly black : tegmina colourless, pale buff and marked with buff at the base; costal margin bright rosy red, darker towards the tips, black on the stigma; veins tawny, black towards the tips ; first and seeond transverse veins and the longitudinal vein between them, elonded black : veins of the wings pale tawny with black tips and the tips of the flaps clouded brown. In the $f$ the abdomen is a little longer and more pointed than in the $\sigma$.

\section{Species of doubtful position.}

oCicada rugipennis, Walker, Ins. Sannd., p. 17 (1858).

$\sigma^{7}$. Luteous-testaceous, stout: pronotum much broader behind than in front, sides straight, sutures strongly marked : abdomen with a blackish band on the fore border of each segment: wings white, rather broad, very stout and rugulose: tegmina slightly rounded in front, costa and veins reddish, the latter black at the tips ; 1-3 transverse veins and most part of the intermediate veins, clouded black: wings with a short angular band in front at two-thirds of the length. Body long, $29 \frac{1}{2}$; teg. 84 millims.

Reported from India.

DCicada delineata, Walker, Ins. Saund., p. 17 (1858).

. Black, testaceous beneath : ocellar space and two irregular stripes on the head, the frons, margin of pronotum, six irregular stripes on the mesonotum and a spot and dot on each side in front between the intermediate and extcrior pair of stripes, a band on the posterior margin of each abdominal segment and the abdomen for the most part beneath, legs, and veins on the tegmina towards the base, testaceous : transverse streaks on the frons, six various stripes on the pronotum and the sutures in part, also three spots on each side, stripes on the femora and tibio and veins of the tegmina above the base, black: tegmina and wings vitreous. Body long, 21 ; teg., 63 millims.

Reported from India.

o Cicada subvenosa, Walker, Ins. Sannd., p. 18 (1858).

$\sigma^{7}$. Pale testaceous : greatest part of the vertex, 2-4 stripes on the pronotum, also a dilated spot by the border, four stripes on the mesonotum of which the middle pair are short and two dots behind these 
and a spot at the base of the abdomen, black: pronotum a little broaler than the head with a brown spot on each side hindward; the outer pair of black spots on the mesonotum -contain between them some forked testaceous lines: tegmina and wings vitreous, veins pale testaceous, the first and second veins of the tegmina slightly elouded brown. Body long, $14 \frac{1}{2}$; teg. 38 millims.

Reported from India.

o Cicada strigosa, Walker, Ins. Sannd., p. 19 (1858).

ð, q. Black: transverse lines on each side of the face, a stripe on the pronotum, the abdomen beneath more or less, greatest part of the femora, a band near the base on the tibiæ, testaceous : tegmina and wings vitreons, with a very oblique interrupted brown loand which extends along the transverse veins; veins testaccous, black towards the tips: tho basal area and the base of the sixth ulnar area, clouded brown and with a short brown band which oxtends across the tip of the front area; a brown mark at the tip of the first apical area : abdomen in $\sigma^{7}$ with

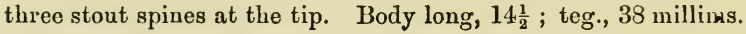

Reported from India.

O Cicada virguncula, Walker, J. Linn. S. Zool. i, p. 84 (1856).

Green : head small : drums very small : abdomen luteous above at the base, hind borders of the segments, luteous : wings vitreous ; costa and veins green. Body long, $13 \frac{1}{2}$; teg. $35-36$ millims.

Reported from Singapore, Malacca.

$\checkmark$ Genus Cicadatra, Amyot.

A. S. E. F. (2 sér.) v, p. 152 (1847) : Fieber, Rev. Mag. Zool. (3 sér.) ii, p. 338 , t. 3, (1875).

In A. S. E. F. (4 sér.) i, p. 617 (1861), Stål unites Tettigia and Cicalatia and makes them subgenera of the united genus. Fieber (l. c.) keeps them separate and describes Cicadatra as having the anterior femora trispinose : pronotum trapezoidal : covering of the drums semioval or broadly triangular, concealing more or less the drums, and moreover a subulate projection or point: the genital sheath (porte-pénis) in the $\sigma$ is corneous, elongate or linear and has at the tip a bundle of ribbon-shaped white or brownish appendages with numerous points: the two sectors spring each from one of the angles of the short basal cellule of the tegmina, the angles separated by a short, oblique, vein : rostrum reaching only the middle or the usually convex end of the mesosternum. In Tettigia, the anterior femora are bispinose : pronotum trapezoilally broadened backwards : the drums almost eovered by a broad semioval plate : the genital sheath in $\sigma^{\pi}$ is corneous and ends in two horns, in- 
curved towards the base : the two sectors spring from the elongated basal cellule at a right angle, the exterior sector rising at the internal inferior angle, the other a little higher at the tip of the short, oblique, intermediate vein : the rostrum long, reaching the first ventral segment, basal joint prominulous, third joint about $3 \frac{1}{3}$ times longer than the second, clypens long, triangular, acute, four-fifths of the length of the frons: space between the scrobe and the eye almost twice as large as the scrobe: mesosternum broadly triangular, convex with a short and weak apical groove: metasternum in the $\sigma^{x}$, obtuse, quadrangular, free.

\section{Cicadatra striata, Walker.}

J. A. S. B. liii, (2), 229 no. 71 : liv, (2), 116.

․ Body tawny: head with a broad, slightly interrupted black band; face convex, with a row of black bands on each side : rostrum tawny, piceous towards the tip, reaching the hind coxø : pronotum partly black above, with a short, broad, yellow stripe in the middle : mesonotum mostly occupied by four very broad black stripes, the lateral much longer than the median pair and with two tawny streaks : abdo- men mostly piceous above : legs tawny: first femora with three rather long teeth: tegmina and wings colourless, veins tawny, black towards the tips; the first and second transverse veins clouded with brown : fore-

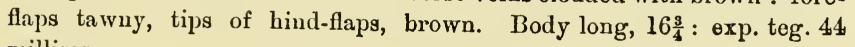
millims.

\section{3) 66. Cicadatra xantes, Walker.}

J. A. S. B. liii, (2), p. 230, no. 75 ; liv, (2), p. 117.

б. Body tawny : vertex with two very large black spots; face red above with a piceous stripe in front : rostrum tawny, tip black, reaching the intermediate $\operatorname{cox} \circledast$ : antennæ tawny, piceous at the bases and tips: pronotum with a yellow stripe on each side of which there is a short, slightly curved stripe and a small spot on the hind border, piceous: mesonotum with four black obconical stripes, the middle pair rather less than half the length of the outer pair and so close together that they almost appear united; behind them are two piceous spots which join the cross-ridge which is ferruginous and small : abdomen ferruginons with a piceous stripe which tapers from the base to a little beyond the middle and then disappears : drum-covers pale tawny, very small, not half covering the tympana which are ferruginous; the opercula bright tawny, rather narrow, of moderate size, about one-third the length of the abdomen : legs tawny ; femora striated ferruginous; tips of claws black fore tibio and feet ferruginous; fore femora with two rather long ferrugi- 
nous teeth : tegmina colourless, veins yellow, on the costal margin a black vein is enclosed between two yellow veins and extends to the pale yellow stigma : flaps with a tawny tinge at the base and along part of the middle vein.

\section{O67. Cicadatra quadrimacula, Walker.}

J. A. S. B. liii, (2), p. 233, no. 93 ; liv, (2), p. 117.

f. Body bright tawny, scarcely pubescent: head, rostrum (base excepted), antennæ, black : pronotum with a slightly curved stripe on each side, two triangular spots on fore border, three small spots on hind border, and some indistinct marks on the disc, black: mesonotum with four very large black spots of which the outer pair are obconienl, slightly oblique, widened to each other at the base, on the immer side slightly emarginate by a very slender short oblique tawny stripe, the third spot much shorter and apparently divided into two U-shaped spots, the fourth behind the third, quadrate, with a slender cone on its fore border : a large spot on each side at the base of the antennæ, a small one in front of the liead and three along the hind border, and the base of the rostrum, tawny : abdomen black above, posterior dorsal margins of tho segments with an interurrupted reddish band, a broad pale tawny band near the tip, horn pale tawny; beneath piceous, posterior margins of the ventral segments, ferruginous, tip pale tawny : drum-covers very small, pale tawny, with blackish discs partly covering the tympana, which are greyish; opercula bright tawny, small, far apart: legs tawny: coxæ, posterior femora and last tibiæ striped black; claws ferruginous; first femora black with a tawny spot near the tip and with three robust black teeth; first tibir black with a slencler tawny band near the base, middle pair black ; first and mildle feet, piceous ferruginons at the base, last pair tawny with piceous tips: tegmina whitish, pale tawny and marked with black at the base, costal margin bright tawny, stigma pale brown, veins pale tawny, black towards the tips first and second transverse veins and the space between them and ths costal margin elouded very dark brown; fore-flaps pale tawny : wings with the first and second transverse veins and the space betwoen them clouded very dark brown, flaps white at the base and along some part of the hind border.

\section{UGenus Cryptotympana, Stål.}

J. A. S. B. liii, (2), p. 230.

Head very broad, about as broad as the thomx; fins ocenpying abont a third part of the breadth of the face : thorax very slightly am42 
plified backwarls from the apex; the lateral margins dilated, straight or slightly sinuated; anterior angles distinct; posterior limbus broad: scutellum posteriorly depressed, slightly sinuate at the apex: tegmina with eight apical areas, basal cell sending out two veins which are rather broadly distant: wings with six apical areas; abdomen obconical, tympana entirely hidden above by the very large lobe of the dorsal segment which is produced forwards : opercula large, flattish, contiguous inwards or slightly valvate: metasternum furnished with a stout process which is curvedly produced from the base backwards : first pair of femora beneath with two large spines and near the apex with an obsoletc, obtuse, small tooth (Stål.)

\section{O68. Cryptotympana recta, Walker.}

\section{J. A. S. B. liii, (2), p. 230, no. 77.}

. Body black, short, broad, tawny pubescent in parts : rostrun black, tawny at the base, reaching the last coxæ : antennæ black : posterior lobe of the pronotum with two large tawny spots; the mesonotum with two small tawny spots near the middle of its posterior margin : opercula tawny, very small, wide apart: legs dark tawny; femora, especially the first and intermediate pairs, striped black; tips of the tibie, feet, and fore-tibia, black; first femora with three black teeth of which two are long and one is very small : tegmina colourless, green along the costal margin for half its length, dark brown thence to the tips, black towards the base, to this colour succeeds a small space having. an opaline lnstre; veins tawny, black towards the tips; the first and second transverse veins and the adjoining longitudinal veins are clouded dark brown; flaps black towards the base.

\section{Co9. Cryptotympana vicina, Signoret.}

J.A. S. B. liii (2), p. 23 J, no. 78 : includes Fidicina bicolor, Walker, List Hoın. B. M. iv, p. 1121 (1858), from Java.

Much smaller thar C. acuta, Signoret, from which it differs only in the absence of patches on the pronotum and in the complete transparency of the wings in the external portion : the opercula are proportionately less elongate, but of the same form $\left(\sigma^{*}\right)$.

\section{Crsptotympana indaculata, Olivior.}

\section{J. A. S. B. liii, (2), p. 231, no. 79.}

Black : wings, hyaline, spotless : abdomen black : opercula reddish : two spines on the first pair of femora, acute, larger than usual (Olivier). Head and thorax blackish brown, abdomen black; three red ocelli on 
the head: opercula orange red: first pair of femora with two robust spines : tegmina and wings hyaline, immaculate, margin of the brown colour of the body beneath. Differs from $\boldsymbol{\omega}$. intermedia, Signoret, in having the tegmina and wings entirely transparent, ilic opercula smaller thongh of the same colour, and the femoral spines apparently more robust. Body long, 50 : exp. teg. 112 millims.

0 71. Cirptotrmpana intermedia, Signoret.

J. A. S. B. liii (2), p. 231 , no. 80.

Differs from $Q$. atrata, Fabr., in the absence of patches on the pronotum and scutellum, whilst those on the head are larger : the brown basal patcl on the tegmina is not so large and cloes not extend beyond the basal cell: opereula are altogether yellow and are larger, elongate, flattened, and with a rim : abdomen reddish yellow with a blackish band on each seguent; sides brown. From Temasserim (Walker); China (Signoret, B. S. E. F. (6 sér.) i, p. xli, 1881); Java (Sign.).

\section{Cryptotympana atrata, Fabricius.}

Tettigonia atrata, Fabr., Syst. Ent. p. 681 (1775) ; Spec. Ins. ii, p. 321 (1781); Mant. Ins. ii, p. 267 (1787); Ent. Syst. iv, p. 2t (1794); Syst. Rhyng. p. 42 (1893).

OTettigonia pustulata, Fabr., Ent. Syst. iv, p. 20 (1794); Syst. Rhyng., p. 37 (1803).

Cicada nigra, Olivier, Enc. Méth. v, p. 750, t. iii, f. 5 (1790) : Stoll, Cig., p. 84; t. 22, f., 118 (1788), La Cigale Chinoise noire.

Cicada atrata, Germar, Thon's Archiv. ii (2), p. 65 (1830); Silb., Rev. Ent. ii, p. $68(1834)$.

C. Cicada atra, Signoret, Rev. Mag. Zool., p. 406, t. 10, f. 1.

D Fidicina atrata, Wal ker, pt., List 11 om. B. M. p. 89 (1850).

C Cryptotympana nigra, Stil, Hem. Fabr. ii, p. 6 (1868); Ofvers. K. V.-A. Förh., p. 714 (1870).

Cryptotympana atrata, Stål, A. S. E. F. (4 sér.) i, p. 613 (1861).

Entirely dull black; the margin of the abdomen, especially of the last segment, testaceous : tegmina and wings whitish, black at the base, veins testaceous $(\mathrm{Fabr}$.). This description is copied throngh all Fabricius' works and the reason for Stal giving in his later writings precedence to Olivier's name is not understood.

Black, varied with reddish yellow; tegmina and wings hyaline raried with brown : head with a reddish longiturlinal patch in the middle of the frons, ending below near the eyes and another transverse patch ; pronotum with a patch on each side on the posterior margin, 2-4 on the scutellum, one at each angle: tegmina and wings with a broad opaque, basal, brownish patch occupying the basal cell of the tegmina, which are in the opaque portion veined yellowish, and also in a part of the transparent 44 
portion, but becoming obscure and black towards the apical anastomoses : abdomen black, margined yellow : opercula moderate, tumid, rounder, blackish-brown bordered with yellow : feet black, varied with yellow. Long. 47 : exp. teg. 134 millins.

Reported from China, Java, but likely to be found in India.

\section{D73. Cryptotympana acuta, Sigmoret.}

- Cicada acuta, Sign., Rev. Mag. Zool. p. 409, t. 10, f. 3, 3 A (1849).

O Fidicina acuta, Walker, List Hom. B. M. ii, p. 81 (1850).

OFillicina nivifera, Walker, l. c. p. 80 (1850).

Cryptotympana acuta, Stål, A. S. E. F. (4 sér.) i, p. 613 (1861) ; Ofrers. K. V.A. Förh. p 483 (1862); p. 714 (1870).

Black : two reddish brown patches on the pronotum and a yellow hand on the posterior margin : mesonotum with six stripes, of which the two median are small : scutellum reddish : metanotum reddish on each side with two median patches: tegmina and wings brownish at the base, the external cellules and the two first anastomoses only being slightitly smoky : abdomen with a large farinose patch on each side of the first three segments, which is only feebly indicated on the fourth, beneath blaek varied with red : opereula large, elongate, ending in a point and sinnate on the margins, entirely yellow : feet black, varied with yellow. Budy long, 42: exp. teg. 130 millims.

Reported from Java, Philippines, likely to be found in India.

74. Cryptotympana corvus, Walker.

J. A. S. B. liii, (2) p. 231, no. 82 : liv (2), p. 117.

ㅇ. Body black, short, broad, adorned here and there with patches of bright tawny down : a tawny spot on the face : rostrum and antenuæ, black, the former reaching the hind coxæ: abdomen with a tawny spot on each side of the tip beneath : legs black ; femora striped tawny, hind tibio tawny, black at the base and at the tips: first femora with two long, black teeth : wings nearly colourless, with a slight pale brown tinge at the tips, very dark brown towards the base, costal margin dark brown, striped with green, veins black, greenish towards the base. Body, long, 36 : exp. teg. 113 millims.

\section{$\cup 75$. Cryptotyapana вUBo, Walker.}

J. A. S. B. liii, (2), p. 231, no. 81 : liv (2), p. 117.

๙. Body black, short, broad, shining, partly clothed with tawny down which forms patches on the thorax : head with five tawny spots in front, the largest on the vertex; rostrum and antennæ, black : eyes 
prominulons : the pronotum with two dark tawny spots near the hind Lorder, posterior inargin of posterior lobe dark tawny, and the mesonotum on each side with two tawny spots: abdomen obconical, a little longer than the thorax, with a dark tawny stripe along each side beneath: drums black, rather large; opercula large, black, nearly lialf the length of the abdomen, irregularly triangular, tawny on the onter sides and at the tips, which are narrow and pointed: legs black; femora tawny beneath except at the base and tips; a slender tawny band near the base of each middle tibia; hind tibir tawny, black at the base and at the tips; a broad tawny band on each hind foot: first femora strongly bidentate: tegmina dark brown for half the length from the base, slightly tinged with brown thence to the tips, adorned at the base of each tegmen witl a tawny spot, beyond which is a tawny stripe extencling nearly half the length of the fore border; veins tawny for half the length from the base, black from thence to the tips. \& has the abilomen much longer than the thorax. Bocly long $36-40$; exp. teg. 117-118 millims.

O 76. Cryptotympana (P) invarians, Walker.

OFidicina invarians, Walker, Ins. Saund. Hom. p. 11 (1858).

+. Black : wings vitreons, black at the base ; veins reddisl, partly black along the costa : tegmina with the first and second transverse veins black, very oblique, first very slightly clouded, the third and fourth

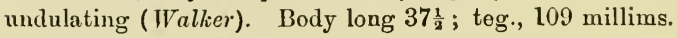

Reported from India.

\section{Cryptotympana facialis, Walker.}

O Cicada facialis, Walker, List IIom. B. M. Suppt. p. 30 (1S58).

§. Black, slightly clothed with pale golden pubescence on the borders of the segments : head with a luteous spot on each side in front between the eyes; face with a luteous stripe, its lateral margins testaceous : abdomen with 2-3 slight tawny bands in the midlle beneath : legs partly tawny, tegmina and wings vitreous, black at the base; reins tawny, black at the tips, first and second transverse veins slightly clouded with black (Walker). Body long 37-38; exp. teg. 100-101 millims.

Reported from Siam.

\section{Criptotimpana fomipennis, Walker.}

O Fidicina fumipennis, Walker, List Hom. B. M. Suppt. p. 17 (1858).

б. Black : a streak on the head on each side before and behind, and an undulating streak on each side of the pronotum, ferruginous : 46 
licad here and there tawny pubescent: pronotum with a median stripe und hind horder, tawny, the latter edged black : mesonotum with four tawny stripes, inuer pair short, outer pair partly ferruginous : abdomen with a broad tawny stripe on each side at the tip : opercula acute, slightly falcate, extending to laalf the length of the abdomen, broadly tawny along the exterior side : leg's partly tawny : tegmina and wings nearly vitreous in the middle, green towards the base, brown about the tips and along the external margin ; veins green, black towards the tips; first and second transverse veins on the tegmina clouded dark brown (Walker). Body long, 22 : exp. teg. 121-122 millims.

Reported from Siam.

\section{OGenus Tibicen, Latreille, Stål.}

J. A. S. B. liii, (2), p. 231.

Body obloug : head varying in breadth, rarely broader than the anterior margin of the thorax; frons slightly or moderately convex, occupying not mole than half of the breadth of the face, furnished with a longitudinal groove : clypeus subacuminated at the apex or slightly truncated : rostrum short or moderate: ocelli remote from the base of the head: sides of thorax rarely a little dilated, very often convex, amplified posteriorly : costal margin of the tegmina not or towards the base only a little dilated, ulnar veins very often entirely distant, never contiguous; eight apical areas, first apical area extended farther forwards than the second : tympana entirely visible : anterior margin of the posterior part of the first dorsal segment of the abdomen not amplified in a lobe, straight : last.ventral segment in $q$ deeply and broadly emarginated : opercula small or moderate, not valvate, rarely contiguous : first pair of femora spinose beneath (Stål). In Hem. Afric. iv, p. 26 (1366), Stål distributes the African species of this genus amongst the subgenera, "Abricta, ${ }^{\circ}$ 1broma, Quintilia, and ${ }^{\top}$ Ppora, to which, in $1870, \mathrm{~h}_{\mathrm{e}}$ added Nelcynda. The Indian species ${ }^{2} T$. brunneus, Fabr., belongs to the subgenus 'Abricta and $T$. apicalis, Germar, to ${ }^{2}$ Abroma.

\section{O 79. Tibicen aurengzebe, Distant.}

J. A. S. B. liii, (2), p. 231, no. 83.

$0^{x}$. Body above dull ochraceous. Head with the front margined anteriorly by two narrow black striæ; ocelli narrowly margined with black; eyes pale ochraceous : pronotum with a central longitudinal sulcation, bordered with a small fuscous spot on each side at the anterior margin, starting from a wide, transverse, and somewhat raised base, on the midlle of which is a fuscous spot; oblique striæ narrowly fuscous; 
lateral anterior and posterior margins much paler: mesonotum with two short obconical median fuscous spots and a large sublateral and somewhat broken fascia of the same colour on each side : abdomen with the posterior segmental margins narrowly and obscurely paler. Body beneath concolorous; middle of the face, metasternum, disc and apex of the abdomen, fuscons: legs concolorous, femora streaked with fuscons ; bases and apices of tibix, and apical points of tarsi, also fuscous. Tegmina and wings pale hyaliue and talc-like; tegmina with costal and basal half of venation ochraceous, remainder fuscous; transverse reins at the bases of the second and third apical areas infuscated. Width of head, between the outer margins of the eyes, rather less than that of the pronotum at the base; pronotum a little more than tivice as broad as long; face with the base much elevated, somewhat narrowing to the apex, distinctly longitudinally sulcated, and strongly transversely striate : rostrum about reaching the posterior coxæ, with the apex pitchy; opercula slender, curved inwardly, but not meeting at the base or apex (Distant). Long. 18 : exp. tegm. 48 millims.

\section{Tibicen apicalis, Germar.}

\section{J. A. S. B. liii (2), p. 231 no. 84 : liv (2), p. 117.}

ㅇ. Head somewhat broader than the base of the thorax, black, frons tumid, basal spot ferruginons: thorax anteriorly much narrower than the head, sides obtuse, slightly converging backwards, posteriorly abruptly amplified, posterior limbus narrow ; npper apical segment in $q$ with two black stripes. Very near ${ }^{0} T$. brunneus, Fabr., but differs in being smaller, head broader, frons much.more tumid, sides of thorax slightly converging backwards, and in the markings. In the form and structure of the tegmina, abdomen, and spine of posterior trochanters, it agrees witls' $T$. brunneus (Stål).

\section{Tibicen subvitta, Walker.}

J. A. S. B. liii (2), p. 230, nos. 71, 73 : liv (2), p. 117.

o. Body black, scarcely pubescent : a small tawny spot on the vertex between the ocelli and the hind border : rostrum and antenno black, the former reaching the intermediate coxre : pronotum with a slender tawny stripe extending from the fore to the hind border: abdomen obconical, piceous, tawny at the tip, beneath ferruginous and tawny towards the tip; [drums large, pale brown and opercula tawny?]: legs black; femora striped red; claws and hind feet tawny; femora with three tawny teeth, of which one is very long and two are of moderate size; hind tibiæe tawny towards the tips: tegmina ancl wings 
colourless, whitish and tinged with red at the base, veins pale tawny, black towards the tips: basal cell and adjoining veins clouded brown: tegmina with two oblique dark brown bands, the first interrupted, the second oecupying the transverse veins, but not reaching the hind border; a small dark brown spot on the tips of the fore border; a row of pale brown spots oecupies the tips of the veins of the apical areas; fore membranes whitish : wings with a broad, interrupted oblique brown band whieh communieates here and there with the base along the borders of the veins; flaps colourless, brown along the fore border and towards the base, where they are whitish; veins tawny; black towards the tips.

\section{O 82. Trbicen pusillus, Fabricius.}

O Tettigonia pusilla, Fabr., Syst. Rhyng. p. 44 (1803).

O Cicada pusilla, Walker, List Hom. B. M. i, p. 229 (1850).

Small : thorax flavescent; the anterior lobe, a pale dorsal line, and small impressed lines, black, the posterior lobe with four dull black spots at the base, tho lateral ones largest: abdomen flavescent, segments black at the base : wings lyyaline, costa flavescent : feet flavescent (Fabr.).

Reported from Amboina, India.

\section{o 83. Tibicen (?) nana, Walker.}

Cicada nana, Walker, List Hom. B. M. i, p. 202 (1850).

$\sigma^{*}$. Body tawny : vertex ferruginous, piceous on each side; face with two pieeous stripes in front : rostrum dark tawny, tip black, reaching the intermediate eoxø : antennæ tawny : pronotum ferruginous with a very large triangular black mark on each side : opercula of moderate size, rather less than one-third of the length of the abdomen : legrs tawny; elaws black; femora with three tawny teeth: tegmina and wings colourless; veins tawny, black along the hind borders of the tegmina. Long, $12 \frac{1}{2}$; exp. teg. 29-30 millims.

Reported from Clina.

O Genus Mogannia, Amyot \& Serville.

J. A. S. B. liii, p. 232.

Body elongate: head small; frons conically produced : eyes small seareely prominulous: tegmina large and broad, their basal half coriaceous, more or less transparent, up to a transverse elevated line beyond which, and the wings, hyaline ; costal margin of the tegmina somewhat straiglit before the middle, the second apical area extended forwards to 
a less distance than the first : abdomen stont, inflated, broader than the thorax, a little compressed on its upper surface on both sides, so as to form a kind of ridge (A. $\uparrow$ S., Stål).

- 84. Mogannia conica, Germar.

J. A. S. B. liii, (2), p. 232 , nos. $85^{\circ}$ (M. illustrata), $86^{\circ}$ (1I. vecta) ; liv, (2), p. 117 :

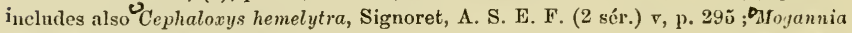
ignifera, Walker, List Hom. B. M. i, p. 249 (1850), from Java, and SMlogannia aticula, Walker, l. c. p. 249 (1850), from Java and the Philippines.

$\sigma^{7}$. Ferruginous : abdomen with a red band on the posterior margin of each segment : tegmiua and wings vitreous, red at the base, reius tawny; the tegmina tawny for more than one-third of the length from the base and having a brown upriglit band dividing the tawny from the vitreous part; the wings brown along the basal part of the hind borde $O$ ( $M$. recta, Walker).

\section{-85. Mogannia obliqua, Walker.}

J. A. S. B. liii, (2), p. 232 , no. 87.

i. Green, mostly reddish beneath : head black along the lind border : pronotum with some testaceous marks and a black stripe dilated backwards : mesonotum with some testaceous murks and a black stripe dilated before and behind : abdomen reddish with a spot on each side near the base and a short band hindward of pale sericeous pile, two green bands near the tip: legs piceous; posterior tibia and tarsi pale green : tegmina and wings vitreous, red at the base, veins green black towards the tips; the tegnina lave a red costa, a brown band extending from the tip of the front areolet obliquely to the lind border, whence it is continued obliquely towards the base of the wing (Wallier).

\section{O86. Mogannia venustissima, Stäl.}

J. A. S. B. liii, (2), p. 232 , no. 88 .

$\delta,+$. Cærulean or brassy black, sordid flarescent-sericeons : tegmina before the middle and the wings sordid lyyaline; the tegmina veined sordid straw-colou;, before the middle black, at the base pale sanguineous; the wings veined fuscous, sanguineous at the base.

- Var. a. Basal spot on frons and oblong median spot on the thorax, sanguineous.

oVar. b. Entire frons, median streak on the thorax contracted in the middle, also veins and band on the black part of the tegmina, weak sanguineous-flavescent; abdomen varying into ferruginous (Slail). 
O87. Mogannia funebris, Stål.

J. A. S. B. liii, (2), p. 232, no. 89.

†. Aenescent-black, fuscous, pilosulons : tegmina and wings vitreous, the former black before the middle, basal area and a band at the apex of the black part, sordid lutescent (Stål).

\section{Mogannia indicans, Walker.}

J. A. S. B. liii, (2), p. 232, no. 90.

§. Body bright or very dark red: rostrum black reaching the intermediate сохю: antennw yellow, blaek at the base : a very large dark ferruginous spot on each side of the fore-chest : mesonotum with a broad, obeonieal, oblique, blaek stripe on each side, the margins of which are also black : pectus black: abdomen blaekish towards the base, tip with a black horn : legs black, pilose : coxio and posterior femora marked with red: tegmina and wings eolourless, tawny at the base; the tegmina with a broad brown band which includes a very irregular yellow band; veins yellow, tawny at the base. + . Body nearly all blaek; a eolourless spot on the base of the brown band of the tegmina (Walker).

O 89. Mogania (?) Locusta, Walker.

J. A. S. B. liii, (2), p. 233, no. 91.

․ Body ferruginous, pale tawny beneatli : two small black spots between the ocelli : rostrum pale tawny, tip piceous, reaeling the intermediate eoxø: antennæ tawny : anterior lobe of the pronotum with two slender black stripes whieh slightly converge from the fore border and then slightly diverging inelude a nearly cireular spaee and are united on the hind border, a small black spot on each side in front; posterior lobe tawny : mesonotum with three slender black stripes, the side pair slightly converging towards the tip of the middle one, sides and hind border tawny, pale yellow sericeous : abdomen pale tawny, with a very broad dorsal ferruginous stripe extending from the base to the narrow part, a row of small piceons spots along each side; last segment piceons above at the base, hor'n tawny, rather long; sheaths pale tawny, piceous and pilose towards the tips, and extending some distance beyond the tip of the abdomen; oviduct ferrnginous, black and serrated at the tip : legs pale tawny; first femora with three tawny teeth, of which one is very small : tegmina eolourless, basal eell, costal margin, and veins pale taivny; wings eolourless, in both fore membranes pale buff, flaps pale buff at the base and for a space along the hind border. 


$$
\text { O 90. Mogannia (P) Lactellennis, Walker. }
$$

J. A. S. B. liii, (2), p. 233, no. 92 ..

67. Body luteons, palely pilose : head black, a small tawny spot at the base of each antenna; a large tawny spot on each sile of the face : rostrum black, tawny at the base; antennæ black: a black band along the fore border of the posterior lobe of the prouotum : mesonotum with four black obconical marks, median pair not more than half the length of the lateral pair, between the former there is a black stripe increasing in breadth from the fore border to the middle where it ceases: abdomen black, posterior dorsal margins of segments tawny, a tawny spot on each sido near the tip which is tawny: drums tawny, small, open, furrows hoary ; opercula very small : legs luteous, a piceous spot at the tip of each tihia ; tijs of claws, black; first femora with two stont teeth which are partly black at the base: tegmina and wings white, opaque, luteons at the base; reins black, tawny towards the base and near the stigma.

\section{O91. Mogannia ineres, Walker.}

Cephalonys hebes, Walker, List Hom. B. M. Suppt. p. 38 (1858).

б. Testaceous: pronotum blackish with a stripe and the border, testaceous; mesonotum with four blackish obconical stripes, the inner pair very short : two black spots on each of the second and third segments of the abdomen : opercula oblique, elongate-conical : tegmina and wings vitreous, veins pale green, black at the tips. Borly long, $16_{4}^{\frac{3}{4}}$ : exp. teg. 42 millims.

Reported from N. China.

\section{Q.2. Mogannia nasalis, White.}

Mogannia nasalis, White, A. M. N. H. xiv, p. 426 (1841); Walker, List Iom. B. M. i, p. $248(1850)$.

Head, thorax, and body finely yellowish-brown sericeous, especially above: near the base of the tegmina is a broad transverse band (widest interiorly) of a glossy yellowish hue, darker on the borders, veins greenish, base and tip quite clear: wings with the veins obscure, inner edge reddish : pronotum with two large rounded spots, one on each side; the margin and a line through each spot, deeply impressed: hind tibio hairy behind with three longish spines on the apical half (White). Long, 22 millims.

Reported from Houg-kong.

52 
U93. Mogannia chinensis, Stål.

O JIoyannia chinensis, Stảl, Ofvers. K. V.-A. Förlı., p. 155 (1865).

$\sigma$. Black, remotely golden-yellow sericeous : a streak and the apical part of the dorsum of the abdomen, densely sericeous : the tegmina and wings vitreons; veins fuscous ; a broad, oblique, sordid stramineons band on the tegmina before the middle, anteriorly and posteriorly the band often interrupted and with a fuscous end: tibio and the posterior tarsi yellow-whitish ; intermediate tibiw at the base and apex and the last pair at the base, black: venter ferruginous. Very like DI. nusalis, White, differs in the larger size, the colour of the posterior tibia, and in the lateral processes of the upper anal segment in ơ being longer (Stål). Long, 18 ; exp. teg. 40 millins.

Reported from N. Clina.

- 94. Cusmuscarta siamensis, Butler.

Cosmoscurtu siamensis, Butler, Cist. Ent. i, p. 245, t. viii, f. 1 (187t) ; J. A. S. B. iv (2), p, $23(1 \mathrm{~s} s 5)$.

Allied tu C.trieulur, St. Farg., but in the form of the thorax more like $U$. divisa, Walker. Head and thorax, basi-costil third of corium, and basal part of the clavus reddish-testaceous: wings pale fuscous, the basi-costal veins and the base, reddish: abdomen above and beneath blue-black : peetus and legs, piceous; hind tibio with a strong spine. A variety has the basal third of the tegmiua reddish-testaceous ( $B$ utler). Luing, 18; exp. teg. t2 millims.

Reported from Cambudia.

\section{95. Cosmuscarta rugulosa, Walker.}

Cercopis raynlusa, Walker, J. Limu. S. Zuol. i, p. 95 (1856), p. 105 (1857). Cosmoscarta ruynlosa, Butler, Cist. Ent, i, p. 219 (1874).

Black, shining; ferruginous beneath: abduminal margius and the legs red : a blackish band on each femur : tegminit ruguluse (Walker). Long, $10 \frac{1}{2}$; teg. $29 \frac{1}{2}$ nillims.

Reported from Singapore, Burned.

\section{○ 96. Cossuascak'ta mataya, Stăl.}

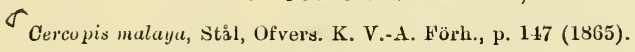

$\sigma^{7}$. Black-violaceons, sparingly pubernlous, tegmina and feet blackish : two snallish spots on the evium behind the mildle, one placed at the costal, the other ublipuely behind it, also two very minute obsolete spots of which one is at the apex of the elavus and the other behind the 
milddle of the costal margin, red. Thorax fairly densely and finely punctured, truncated at the base before the scutellum, margins (anterior excepted) reflexerl, lateral angles obtusely ronnded : scutellum impressed before the middle: tegmina very densely punctulate, scarcely narrowed towards the apex : mosostethium rather distinctly bituberculate, posterior margin not elevated before the coxa (Stål). Long, 8; exp, teg., 23 millims.

Reported from Malacea.

\section{- 97. Cosmoscarta heros, Fabricins.}

- Cercopis heros, Fabr., Syst. Rhyng. p. 89 (1803): Stoll, Cig. p. 104, t. 27, f. 149. (1788) : Stal, Ofvers. K. V.-A. Förh. p. 492 (1862) : Walker, List Hom. B. M. iii, p. 651 (1851).

- Cercopis abdominalis, Westrood in Donovan's Ins. China, p. 39, t. 16, f. 5 (1813) : Walker, 1. e. p. G5f (1851) : J. Linn. S. Zool. x, p. 286 (1867).

Cosmoscarta heros, Stål, Hem. Fabr. ii, p. 11 (1869); Butler, Cist. Ent., i, p.2 51 $(1574)$.

ð, thorax gibhons, dull black, spotless: tegmina dull black, the base and a median band, orange-fulvous: abdomen red (Fubr.). Long with teg., 16 ; breadtl of thorax, $6 \frac{2}{3}$ millims.

Reported from Hong-Kong.

09. Cosmóscarta discrepans, Walker.

0 Cercopis discrepans, Walker, J. Linn. S. Zool. i, p. 95 (1856).

Blackislı-purple, black benenth : tegmina black with an elongated red spot which is contracted in the middle and oceasionally interrupted

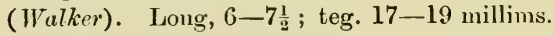

Reported from Singapore.

\section{-99. Cosmoscarta unifascia, Walker.}

Cercopis unifascia, Walker, J. Linn. S. Zool. i, p. 95 (1856).

Red : thorax dilated on each side : disc of the pectus black : tegmi-

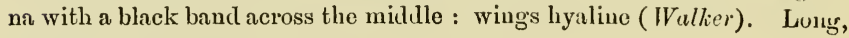
$12 \frac{1}{2}$; teg. 25 millims.

Reported from Singapore.

\section{Cosmoscarta fulvicers, Dallas.}

C Cercopis fulviceps, Dallas, Trans. Ent. Soc. (1. s.) i, p. 10 (1850).

- Head and thorax bright orange, shining : tegmina redlish black, somewhat obscure, outer margins pitchy red : wings bruwuish ; 54 
abdomen beneath black, shining; pectus, legs, and rostrum pitchy. Long, 22 millims.

Reported from Sikkim.

- 101. Cosmoscarta dimidiata, Dallas.

Cercopis dimidiata, Dallas, Trans. Ent. Soc. (n. s.) i, p. 11 (1850).

q. Head black; eyes pale brown, ocelli yellowish-white : thorax very thickly and finely punctured, with its posterior lalf and a transverse quadrangular patch on the anterior margin black; the remainder bright red; scutellum black : tegmina bright red, with three broad irregular black transver'se bands, the first of which rises at the apex of the scutellum, the second a little behind the middle, and the third forms a broad black margin around the apex : body beneath black, shining; legs and rostrum pitcliy (Dallas). Long 15 millims.

Reported from Sikkim.

To the above may be added:-

0

C. pulchella, Butler, Cist. Ent. i, p. 254 (1874). Laos.

o C. exultans, Walker, List Hom. B. M. Suppt. p. 171 (1858). N. China.

O C. bimacula, Walker, l. c. iii, p. 656 (1851). China.

- C. rotundata, Walker, l. c., Suppt. p. 174 (1858). 'Laos.

c C. pellucidu, Butler, Cist. Ent. i, p. 262 (1874). Laos.

O C. Distanti, Butler, P. Z. S. p. 672 (1874). Penang.

102. Pinmatostetha pudica, Walker.

J. A. S. B. liv (2), p. 15, (1885).

Tawny, black beneath : pronotum with a black mark in front, divided by a testaceous stripe and laving on each side of it a testaceous spot; scntellum black with a testaceous str ine abdomen cupreous-black, testaceous at the base and with a row of testaceous spots on each side beneatlı : legs testaceous, tips of femora, black; tibiæ black with a testaceous band near the tip : tegmina brown with a testaceons undulating basal subeostal streak and with two testaceous bands which have black borders in front; the first band at one-third of the length, composed of three spots, the seeond band at two-thirds of the length, entire, attenuated bofore the middle; tips testaceous: wings pale brown, rosy at the base (Walker). Body long, 15-16; teg. 35-36 millims.

Reported from Sillat.

To this add the following :-

( P. semele, Stål, Ofver's. K. V.-A. Förh. p. 151 (1865). Malacca, Lans.

i. l'. triseriata, Butler, Cist. Ent. i, p. 267 (1874). Laos.

o $T$. distoruta, Walker, J. Limm. S. Zool. i, p. 95 (1856). Malacca. 
- P. borneensis, Butler, l. c. p. 268 (1874). Malacea, Ligor, Bornco.

O P. nympha, Stål, l. c. p. 150 (1865). Malacca.

Colsa costestriga, Walker, 1. c. p. 96, t. iv, f. i (1856). Malacca.

\section{- 103. Ptyelus (?) integratus, Walker.}

Ptyelus integratus, Walker, Ins. Sannd. Hom. p. 94 (1858).

Dark testaceous : head with a broad stripe beneath, abdomen in the middle, coxæ, streaks on femora and hind tibie, blackish : tegmina testaceous slightly darker towards the base; wings vitreous (Wuller). Bully long, $7 \frac{1}{4}$; teg. 16-17 millims.

Reported from India.

To this add the following :-

P P. bipars, Walker, J. Linn. S. Zool. i, p. 96 (1856). Singapore.

i P. immutatus, Walker, 1. c., p. 96 (1856). Singapore.

Add the following to the genus Clovis.

- C. multilineata, Ptyelus id., Stål, Ofvers. K. V.-A. Förh., p. 154 (1865). N. China.

O C. malaya, ${ }^{\circ}$ Ptyelus id., Stål, l. c. p. 153 (1865). Ligor, Malacca, China.。

- C. punctum, Walker, J. A. S. B. liv (2), p. 115 inclndes apparently Ptyelus orientalis, Stål, Freg. Eug. Resa, Hem., p. 287 (1859).

Add to the genus Macherota.

Jo M. punctato-nervosa, Signoret, A. S. E. F. (5 sér.) ix, p. xlix (1879). China.

\section{Membracis fuscata, Fabricius.}

J. A. S. B. liv, (2), p. 79 , no. 5.

Thorax foliaceous, rounded, fuscous; with a slender streak before the anterior margin and a broader band before the apex, white: apex acute, black : tegmina fuscous (Fabr.).

- 105. Leptobelus scutellaris, Fabricius.

J. $\Lambda$. S. B. liv, (2), p. 83, no. 12.

Head black : thorax with two, flat, robust, acutc horns, prodnced posteriorly, subulate, entirely black with a broad snow-white, posterior band : wings deflexed, fuscous : costa a little white at the basc: bocly fuscous (Fabr.).

$\bigcirc$ 106. Centrotypus oneratus, Walker.

(7) Centrotus oneratus, Walker, Ins. Saund. Hom. p. 78 (1858).

Tawny : pronotum pubeseent, moderately high, mimutely puncturerl; lateral horns lanceolate, very broad, rather flat, dircetly diverging, 
olliqnely aseending, with a slight ridge, near the hind side of each; posterior horn ridged, straight, very slender, acuto at the tip, extending a little beyond the abdomen: abdomen greyish ferruginous with black points, except along the hind borders of the segments : legs tawny : tegmina tinged slightly testaccous, veins testaceous; wings vitreous, veins black (Wullier). Body long $4 \frac{1}{4}$; teg. $10 \frac{1}{2}$ millins.

Reported from India.

To this add :-

Centrotypus longicornis, Vnillefroy, A. S. E. F. (4 sér.) iv, p. 142, t. 1, f. 8 (18(it). Malacci.

\section{Centrotus (?) Flexiconne, Walker.}

Centrotus flexicome, Walker, Ins. Saund. Hom. p. 78 (1858).

Black : pronotum pubescent, moderately high, very slightly ridged : lateral horns long, acute, diverging, obliquely ascending, slightly inelined backward, much curved, with a ridge near the hind border; posterior horn slender, rilged : femora black : tegmina tinged sliglitly lurid, tawny at the base, costa black towards the tip, veins testaceous; wings vitreous (Wulker). Body long, $6 \frac{1}{4} ;$ teg. $12 \frac{1}{2}$ millims.

Reported from $N$. India.

\section{o 108. Centrotus (P) obliques, Walker.}

Centrotus obliquus, Walker, Ins. Saund. Hom. p. 79 (1858).

Ferruginons very pubescent : pronotum rather high, somewhat scabrous, slightly ridged : lateral horns horizontal, moderately long, diverging, very slightly curved backward; posterior horn ridged, very slender, black except towards the base which is much above the abdomen, contiguous to the abdomen and hardly extending beyond it at the tip: legs

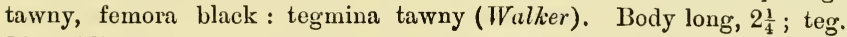
$10 \frac{1}{2}$ millims.

Reported from India.

\section{d09. Centrotus (?) congestus, Walker.}

Centrotus congestus, Walker, Ins. Saund. Hom. p. 79 (1858).

Black, stont, short: pronotum pubescent; rather high, flat above: lateral horns stout, elongate-conical, directly diverging, obliquely ascending ; posterior horn ridged, lanceolate, reacling almost to two-thirds the length of the adodomen : legs tawny; femora black: tegmina tinged slightly grey, a brown mark at the tip of the costa, veins tawny (Walker). Body lung, $3 \frac{1}{2}:$ teg., $7 \frac{1}{2}$ millims. 
Reported from India. T'his is entirely different from the speeies deseribed by Walker under the same name in J. L. S. Zool. x, p. 187 (1867) from Sula.

\section{Centrotus (?) gibbosulus, Walker.}

Centrotus gibbosulus, Walker, Ins. Sand. Hom. p. 80 (1858).

Ferruginous, stout, short : head and pronotum pubeseent, the latter oblique alove the head : lateral horns conical, diverging, extremely short, hardly ascending and curved backwards; posterior horn ridged, lanceolate, black towards the tip, reaching to three-fourths of the length of the abdomen which is black: legs tawny, femora black, tegmina lardly tinged, brown at the base, veins tawny (Walker). Body, long $3 \frac{1}{2}$; teg., $6 \frac{1}{2}$ millims.

Reported from Inclia. This species is entirely distinct from the species deseribed under the same name by Walker in J. L. S. Zool. x, p. 187 (1867) and which should be renamed C. wallieri.

To these add :-

? Centrotus laminifer, Walker, J. Liun. S. Zool. i, p. 93 (1856). Singapore.

$O$ ? C. caliginosus, Walker, l. c. p. 93 . Malacca.

O C. semivitreus, Walker, 1. c. p. 94. Singaporo.

0 ? C. semifascia, Walker, 1. c. p. 94. Malacca.

c. P Micreune formidanda, Walker, 1. c. p. 94. Singapore.

Sipylus crassulus, Centrotus id., Stål. Freg. Eug. Rosa, p. 285 (1859). M Malacca.

Tricentrus fairmairei, Centrotus id., Stàl, l. c., p. 284 (1859). Malacca.

() Gargara malaya, Centrotus id., Stål, 1. c., p. 285 (1859). Malacca.

To Genus LeDrs, and following add :-

$\checkmark$ Ledra auditura, Walker, List Hom. B. M. Suppt. p. 219 (1858). Hong-kong.

$\checkmark \rightarrow$ L. quadricarina, Walker, 1. c., p. 249 (1858). Hong-kong.

$\checkmark$ Tituria nigromarginatd, Petalocephala id., Stål, Ofvers. K. V.-A., Förh., p. 158 (18(5)). Malacca.

$\checkmark \quad$ P Ledra cultellifera, Walker, J. Linn. S. Zool. i, p. 98 (1856). Singapore.

i Ledra conifera, Walker, 1. c., p. 98 (1856). Singapore.

? Ledra nigrilinea, Walker, l. c., p. 98 (1856). Singapore.

P Acocephalus olivaceus, Walker, List Hom. B. M. iii, p. 816 (1851). Malacca, Philippines.

? Celidia guttivena and punctivena, Walker, J. Linn. S. Zool. i, 1. 99 (1856). Malacca.

\section{- 111. Tettigonia albidicans, Walker.}

Tettigonia albidicans, Walker, Ins. Saund. Hom. p. 96. (1858).

Whitish testaceous : a dot on the vertex, stripe on frons, triangular spot on face, two spots on posterior margin of the pronotum and one on the anterior margin, a spot on the scutellum, disc of the pectus, abdomen, 58 
tip of femora, tibire and tarsi and dots on the veins of the tegmina near the tips, black : posterior margins of the abdominal segments and the tip, testaceous : wings blackish lurid towards the tips and along the

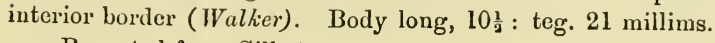

Reported from Silhat.

\section{2. ${ }^{\circ}$ Brthoscopus (?) PUnctifer, Walker.}

$\checkmark$ Bythoscopus punctifer, Walker, Ins. Saund. Hom. p. 104 (1858).

Dull testaceous, stout, very minutely speckled black : a dot on each side beneath at the base of the antennæ, the abdomen above and tips of hind femora, black : tegmina testaceous, veins pale, punctured black ; wings vitreous dark brownish grey (Waller). Body long, $4 \frac{3}{4} ;$ teg., $10 \frac{1}{2}$ millims.

Reported from India.

To these add :-

O Tettigonia tripars, Walker, J. Linn. S. Zool. i, p. 97 (1856). Malacca.

"T. suavissima, Walker, 1. c., p. 97 (1856). Singapore, Borneo.

$\checkmark$ T. jocosa, Walker, l. c. p. 97 (1856). Mount Ophir.

T. suturella, Stål, 1. c., p. 288 (1859). Malacca.

C Jassus (Thamnotettix) since, Stål, l. c., p. 293 (1859). Hong-kong.

○ J. (Thamn.) alacer, Stål, l. c., p. 293 (1859). Hong-kong.

- 113. Fulgora nigrirostris, Walker.

Hotinus nigrirostris, Walker, Ins. Saund. Hom. p. 28 (1858).

Fulgora nigrirostris, Butler, P. Z. S. p. 98 (1874).

Orange : head black, ascending, as long as the body, green beneath, with orange streaks on each side by the eyes : thorax with a broad stripe, pronotum with a band on each side, mesonotum with a streakand three dots on each side and the anterior tibiø, black : tegmina black, very closely reticulated orange and with six orange bands, the first and third bands regular, second slightly dislocated hindward where it sometimes joins the third, fourth formed of three swall widely separate dots, fifth of 4-5 large spots usually confluent, sixth very irregular of 3-5 spots and dots of various size : wings with the apical third black (Walker). Body long, $36-44$; teg. $63-75$ millims.

Reported from India?, Pachebon (Siam). Distinguished from $F$. viridirostris by its brighter orange colour, by its longer head, and by its tegmina, which are more regular and not bordered white.

\section{Hotinus ducalis, Stål, Trans. Ent. Soc. (3 ser.) i, p. 576 (1863). \\ 114. Fulgora ducalis, Stål.}

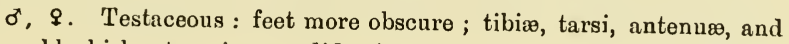
venter blackish : tegmina sordid virescent-whitish, black-fuscous to- 
wards the apex, veins virescent; three transverse rows of spots before the middle; a broad band behind the middle; some small spots, girdled white, placed behind the band, the veins green; apical part sparingly sprinkled with small whitish dots : wings whitish-green, apical part, black: cephalic process very long, gradually compressly narrowed to the apex, moderately curved. In stature similar to $\mathrm{F}$. candelaria, Linn., cephalic process longer and, seen from the side, broader, frontal ridges more distinct ( $\dot{S} t a ̊ l)$. Long, $42-46$; exp. teg. $80-94$ millims.

Reported from Cambodia.

\section{$\checkmark$ o 115. Fulgora calestina, Stål.}

l'O Hotinus calestinus, Stål, Trans. Ent. Soc. (3 ser.) i, p. 676 (1863).

+ Weak grecn-olivaceous, venter and fect black-fuscous: licad obscurely fuscous-testaceous: tcgmina pale sordid alliaccous with threo viresecnt-veined, blackish bands, the first broad near the base, hardly visible except on the clavus, the second narrow, placed a little before the middle and very narrow in the middle, the third broad and with thrce pale virescent olivaceous spots, the apical part behind this band greyish-whitish sprinkled witl pale-cinctured olivaceous spots ; the disc of the apical areas fuscous : wings of a beautiful azure, apical part black. Allied to $F$. ducalis, Stål, but the cephalic process is longer, fuscous-testaceous, much curved. Head gradually compressly narrowed from the base towards the apex, a little longer than the body, not impressed above before the middle (Stål). Long, 41 : exp. teg. 90 millims.

Reported from Cambodia. This species is very close to ${ }^{\circ} \mathrm{F}$. connec. tens, mihi, described from Tenasserim at p. 130 (1885).

\section{Pyrops nobilis, Westwood.}

- Fulgora nobilis, Westwood, Trans. Linn. Soc. xviii, p. 146, t. 12, f. 10 (1841).

Pyrops nobilis, Walker (exol, syn.), List Hom. B. M. ii, p. 268 (1851) ; J. Linn. S. Zool. p. 96 (1856).

Head with a process which is straight, gradually attenuated, obliquely truncated at the apex, furnished with acute black tubercles arranged longitudinally in six rows, of which two are above, two beneath, and two lateral : eyes pale fuscous, a pale acute tubercle behind the eyes : antennæ pale: rostrum scarcely reaching the lateral pair of feet; head proand meso-notum and tegmina luteous greyish, slightly tinged virescent, sprinkled with minute black spots : metanotum and abdomen fulvousfuscous, the latter with transverse black spots: tegmina with numerous larger fulvous dots : wings white, somewhat opaque ; veins pale, tinctured virescent : feet concolorous, with black bands; last pair of tibir inwards immaculate, externally punctured black; tarsi luteous; claws 
black (Westw.). Body with cephalic process, long, 63 ; cephalic process, long, 25 ; exp. teg. $115 \frac{1}{2}$ millims.

Reported from Malacca, Sumatra. ${ }^{\circ}$ P. javanensis, Distant, is closely allied to $P$. nobilis, West., from which it differs thus:- - the prolongation of the head is not prominently and dentately spined as in $P$. nobilis, but only obtusely spined, thus giving the head a much more slender appearance, the spines in both species being arranged in six longitudinal rows, two above, two beneath, and one on each side: the black spotting is also much more minute and the colour of the dorsal surface of the abdomen is different. ${ }^{0} P$. mustelinus, Distant, also from Java, is allied ${ }^{1} t_{0}{ }^{\circ} P$. punctatus, Olivier, from which it differs by the much more prolonged head, the apex of which is not distinctly curved upwards, and which is also more spotted with black than in Olivier's species : the abdomen above is ochraceous and not black, \&c.

\section{$\checkmark$ ○ Genus Cynthila, Stål.}

Stettin Ent. Zeit. xxiv, p. 230 (1863).

Head narrower than the thorax; protuberance slender, porrect: frons much narrowed towards the base with two obsolete parallel ridges ; vertex sinuated at the base, a little broader than the eyes, ridged longitudinally in the middle : second joint of the antennæ subglobose : rostrum extending almost to the apex of the abdomen : thorax in the middle produced anteriorly in an angle, longitudinally ridged in the middle, very broadly sinuated at the base : scutellum tricarinate: tegmina somewhat narrow, scarcely amplified towards the apex, rounded at the apex with longitudinal veins rarely furcated, almost entirely transversely venulose: wings less ample, tegmina much shorter, posterior margin not sinuated, transverse veinlets remote: feet slender, last tibiø 5-spinose. Allied' to Ulasia (Stål).

\section{Cynthila ferocula, Stål.}

Cynthila ferocula, Stål, Stettin Ent. Zeit. xxiv, p. 230 (1863).

$\sigma^{*}$. Livid : here and there pale ferruginous : almost entire clypeus, the cephalie process, and the basal limbus of the abdominal segments, infuscate: very broad streak on the frons, dilated towards the apex, four small spots on the vertex, two longitudinal lines diverging backwards, posteriorly abbreviated, also several small spots sprinkled over the thorax above and two spots on the same between the lateral ridges and a broad patch on the deflexed sides, minute spots scattered over the scutellum, and bands and spots on the feet, blaek fuscous : last tibiæ nuculoured: tegrnina weakly ferruyinuus from the base to beyond tho mid- 
dle, opaque, sparingly sprinkled fuscous, apical part somewhat vinaceous, veined ferruginons sprinkled with larger spots arranged in a longitudinal row and some minute spots, black fuscous: wings vitreous, veined fuscous, infuscate at the base at the longitudinal veins. Close to C. apicalis, Westw., smaller, scarcely differing except in the shorter and more slender cephalic process, which is slender, not or scarcely thickened towards the apex, produced obliquely forwards and upwards, as long as the scutellum (Stål.) Long incl. ceph. process, 20 ; exp. teg. 48 millims.

Reported from Ligor, Malacca.

\section{Genus Scamandra, Stål.}

Stettin Ent. Zeit., xxiv, p. 232 (1863).

Head not protuberant; frons a little broader beneath than above the middle, with the lateral margins of both halves somewhat, parallel, and sinuated in the middle of the lower half, abruptly narrowed at the base and very slightly reflexed, not higher than the vertex, emitting from the base a small (mobile P), cylindrical, furrowed cor'puscule, reflexed above the anterior part of the vertex, furnished with two, sometimes obsolete, parallel ridges: thorax not ridged in the middle : first pair of femora not or scarcely amplified above at the apex; last pair of tibire, with three spines, furnished above at the base with a tubercle, often much elevated and acute (Stål).

\section{- 118. Scamandra hecuba, Stål.}

Scamandra hecuba, Stål, Stettin Ent. Zeit., xxiv, p. 234 (1863).

i. Ochraceous, beneath more obscure : tegmina less obscurely sordid subsanguineous, sprinkled with small fuscous spots which are sometimes encircled pale, almost half the apical part fuscescent-ochraceous anteriorly rounded, veined pale and subsanguineous: wings purely and obscurely sanguineous, the base itself black-fuscous, posterior limbus narrowly whitish, apical part fuscescent-ochraceous, anal area at the base with a fairly large flavescent spot: feet blackish : dorsum of the abdomen weakly sordid testaceous-flavescent, anus sangnineous. Close to S. rosea, Guérin, lateral margins of thorax more divergent, tegmina less broad near the apex, apex semicircularly not obtusely rounded; the apical ochraceous part of the tegmina is larger, anteriorly less distinctly not ending in a pale arch, remaining part without fuscous bands : wings scarcely whitish veined on the disc (Stål). Body long, 23; exp. teg. 74, millims.

Reported from Ligor, Malacca.

62 
- 119. Scamandra Semele, Stål.

Scamandra semele, Stăl, Stettin Ent. Zeit. xxiv, p. 235 (1863).

o. Fawn-colour : basal two-thirds of the tegmina minutely, palely and sordidly sprinkled sanguineous, areolas of the apical part fuscescent in the middle : wings weak sordid sanguineous, base itself black-fuscons, spotted fuscous in the anterior area, posterior limbus whitish, spotted ochraceous, apical part fuscescent, reined ochraceous : abdomen sanguineons, genitalia black: fect, especially the tibiæ and tarsi, infuscate. Form of tegmina very distinct, they are amplified at the apex and rather obtusely rounded, costal margin straight, scarcely sinuated near the apex, commissural margin distinctly sinuated near the apex (Stål). Body long, 13 ; exp. teg. 37 millims.

Reported from Ligor, Malacca.

\section{O 120. Scamandra rosea, Guérin.}

O Aphana rosea, Guerin, Voy. Bél. Ind. Orient. p. 454, t. 3, f. 3 (1834) ; Walker, List Hom. B. M. ii, p. $27+(1851)$ : J. L. S. Zool. i. p. 84 (1858).

1. A Ahena saturata, Walker, J. Linn. S. Zool. i, p. 143 (1857).

Scamandra rosea, Stål, Stettin Ent. Zeit. xxiv, p. 233 (1863).

Head without a prolongation, with the thorax yellow turning into ferruginous : pronotum strongly lobed in the middle of its anterior border, emarginate on its posterior border : tegmina yellow-ferruginous for two-thirds of their length, apical part saffron-yellow, a little browner on the margins : the reddish part is traversed by two oblique brown bands, of which the external is arched outwards with numerous small spots of the same colonr between them : wings rosy turning into vermillion with yellow patches at the base and the tip; the posterior margin with a white smear in the entire rosy space, where also are irregular strio more or less white: abdomen above and beneath vermillion-red with more yellowish transverse bands; feet brown (Guérin). Body long, 21 ; exp. teg. 65 millims.

Reported from Java, Sumatra, Malacca, Singapore.

\section{Aphana farinosa, Fabricius.}

J. A. S. B. liv, (2), p. 142, no. 26.

Head flat, dilated, obscurely ferruginous, with two farinose white spots : thorax ridged, obscurely ferruginous : tegmina white-farinose, at the base fuscous often varied ferruginous, at the apex fuscous hyaline: wings rufons at the base, punctured hyaline, black at the apex: body fuscous; abdomen flavescent ( $F a b r$.). 


\section{$\checkmark$ 122. Aphana atomaria, Fabricius.}

J. A. S. B. liv, (2), p. 143 , no. 27.

A little smaller than $A$. farinosa, Fabr., body dull black; head and thorax flarescent, spotless, the latter carinate: tegmina white-farinose at the base, more obscure at the apex ; with two marginal spots, one at the narrow margin, the larger posterior : wings sanguineous with several white-hyaline and dull black spots, black at the apex (Fabr.).

\section{$\checkmark$ 123. Euphria discolor, Guérin.}

- Aphena discolor, Gnérin, Voy. Bél. Ind. Orient., p. 452, t. 3, f. 2 (1834) : Spinola, A. S. E. F. viii, p. 242 (1839): Walker, List Hom. B. M. ii, p. 273 (1851); J. Linn. Soc. Zool. X, p. 96 (1867).

$\checkmark$ \& Aphena blattoides, Walker, l. c. Suppt. p. 46 (1858).

Euphria discolor, Stàl, Stettin Ent. Zeit. p. 232 (1863).

Head red, oblong, flattened, seen from above little prominent; frons rounded and produced in a small horn curved backwards and scarcely reaching the middle of the pronotum, compressed on the sides and grooved; front of the head oblong, labrum elongate, broad in front, ending in a point and covering the base of the rostrum; the rostrum is longer than the head, four-jointed, tip extending to and passing a little beyond the last pair of coxæ : pronotum black, sinuate in front, finely bordered red, very slightly emarginate behind, about four times broader than long : mesonotum triangular, not so long as broad, almost $t$ wice as broad in the middle as the pronotum, ending posteriorly in an acnte point; it is black with a broad, transverse, rounded, red patch in the middle : the metanotum is not so broad and has several impressions and a smooth elevation in the middle; it is blackish varied with red and has several white farinose patches : there is a small brown triangular piece at the base of the pronotum which covers the articulation of the tegmina; the tegmina are oblong a little amplified at the apex; two and half time longer than broad; veins numerous, of a bright reddish brown especially at the base; marked with irregular black patches more numerous beyond the middle ; tip of saffron-yellow passing gradually into red; between the black patches and the red are large white farinose patches larger at the base and towards the side, which is also marked by large black patches or spots which become smaller towards the tip and form small patches which border the tegmina : wings black with the exterior border brown and the internal margin near the abdomen pale and a little transparent; they are marked with white rounded patehes, farinose and thicker at the base : the abdomen above and beneath brown, orangeyellow towards the borders of the segments, covered above almost entire64 
ly with a white powder similar to that on the wings: thorax beneath, femora and all the feet, red; anterior tibiæ and tarsi, black; intermediate pairs black outwards, reddish within, last pairs red with the tip and tarsi, black (Guérin). Long, body, 23: exp. teg. 75 millims.

Reported from Sumatra, Java, Cochin-China.

\section{O 124. EUphria cornuta, Fabricius.}

1 O Lystra cornuta, Fabr., Syst. Rhyng. p. 57 (1803) ; Germar in Thon's Arch. ii, (2) p. 52 (1830); Guérin, Voy. Bél. Ind. Orient. p. 452 (1834).

V $O$ E. (Callidepsa) cornuta, Stål, Hem. Fabr. ii, p. 87 (1868).

๙. Sordid sanguineous-flavescent : tegmina broadly sanguineous, sprinkled with numerous, here and there confluent, black spots, the very large disc behind the middle, black: wings and tibia sordid sanguineous; the tips of the tibiæ, tarsi, lateral margins of the thorax, and two lateral spots on the pectus, black: basal horn on the frons, erect, gradually acuminated, slender, somewhat larger than the vertex and thorax together (Stå). Body long, 22 ; exp. teg. 70 millims.

Reported from China.

ó 125. Polydictya aphenordes, Walker.

ro Chalia aphonoides, Walker, Ins. Sannd. Hom. p. 31 (1858).

o. Ferruginous : abdomen black with red bands: tegmina with the apical third part paler : wings with whitish reticulations along the interior border and about the interior angle (Walker). Body long $12 \frac{1}{2}$ :
teg. $37-38$ millims.

Reported from Penang.

The present paper concludes this contribution to a 'Homoptera Indica; for the families Psyllida, Coccida, Aphidida, Aleurodida, \&c. have practically been unworked in India, and whoever takes them up will probably have to ignore much that has been written about them. My object has been to provide those who may become interested in this order of insects with some guide to the classification and arrangement, and was at first devoted to the correction of our only English list, but this became so unsatisfactory that it was found better to revise the whole on the basis of Stal's numerous and elaborate essays. I have preferred where possible to give only the original descriptions, but where Stål, Signoret, Butler, or Distant have redescribed a species, their descriptions are recorded. It would have been desirable to give a new description of many species, but knowing the fruitful source of confusion which identi- 
fication without comparison with types has proved in the history of this order, I have translated or transcribed, with some omissions and additions, the origiual descriptions, however unsatisfactory these were. This list of recorded speeies is, it is beiieved, tolerably complete, but we have not in our Indian Museum examples of even a moiety of those given, and I would now endeavour to enlist the efforts of observers in India to complete the series. The number of species here described under each family is as follows :-

$\begin{array}{lr}\text { Cicadidoe, } & 115 \\ \text { Cercopidas } & 67 \\ \text { Membracidce, } & 33 \\ \text { Jassidce, } & 38 \\ \text { Fulgoride, } & 204-457\end{array}$

These with the species indicated as likely to exist but not described bring up the number to close on 500 . These figures could probably be doubled in a few years, for the number of Jassidce alone awaiting examination should add several hundred species to our Indian fauna. 


\section{INDEX.}

This index is to the six papers on Indian Homoptera of which one appeared in 188. (Vol. lii), three in 1885, and tho remainder in 1886. The names of genera are given in capitals, and those generic and specific names which have been sunk or have otherwise fallen out of use are in italics.

A.

ACANTHOPHyes, liv, 84. capra, liv, 84.

Achilina, lv, 36.

Acocephalina, liv, 102.

Acocephalus, liv, 102. olivaceus, lv, 198. stramineus, liv, 102.

Alcathous, liv, 139. fecialis, liv, 139.

Anagia, lv, 24. splendens, 25.

Ancyra, liv, 156. appendicnlata, 156. histrionica, 157.

Aphrophora, liv, 19. sigillifera, 20.

Aphrophorina, liv, 18.

Aphana, liv, 142. albiflos, 148. amabilis, 152. atomaria, 143. aurantia, 151. aurora, 152.

caja, 146. confucius, 144 . delicatula, 150 . dimidiata, 146. dives, 147. farinosa, 142. imperialis, 148. nicobarica, 147. nigro-irrorata, 144. nigro-maculata, 153. pulchella, 144 . resima, 151. scutellaris, 142. variegata, 145 .

Aphana, liv, 142. albiflos, 148. atomaria, 143. blattoides, lv, 204. basirufa, liv, 145. caja, 145.

confucius, 144. delectabilis, 149. delicatula, 150. discolor, $1 \nabla, 204$. dives, liv, 147, 152. farinosa, 142. imperialis, 148. io, 144 . lectissima, 151. nigro-irrorata, 144. nigro-maculata, 153. nigro-punctata, 143. operosa, 150. paulinia, 145. placabilis, 148. pulchra, lv, 22. pulchella, liv, 144. sanguinipes, $\mathrm{l}, 121$. saturata, 203. saundersii, liv, 143. scutellaris, 143. submaculata, 151. uniformis, 155. 
variegata, 145 .

veris-anor, $\mathrm{lv}, 22$.

Atracis, lv, 81. pruinosa, lv, 81 .

B.

Benna, $17,34$. capitulata, lv, 135.

Bidis, $1 \nabla, 35$. notivena, 36.

Beturia, $1 \nabla, 178$.

Brixia, lv, 33. meander, lv, 34 .

Brtnoscopus, liv, 102. indicatus, liv, 102. punctifer, lv, 199. stramineus, liv, 102.

\section{C.}

Callipsaltria, lv, 178.

Callitettix, liv, 17. melanochra, liv, 17. producta, 18. versicolor, 18.

Calyria, 1v, 178.

Carineta, 1v, 176. expansa, lv, 176.

Carystus, liv, 21. viridicans, 21.

Centromeria, 1v, 25. speilinea, $1 \mathrm{v}, 25$.

Centrotina, liv, 76.

Centrotus, liv, anchorago, liv, 87. antilope, 86. assamensis, 88. caliginosus, 1v, 198. capra, liv, 84. congestus, lv, 197. costalis, liv, 88. crassulus, 1v, 198. dama, liv, 81 .

68 fairmairei, lv, 198.

flexicorne, 197.

flexuosus, liv, 87.

gazella, 81 .

gibbosulus, lv, 198.

hardwicliii, liv, 80 .

laminifer, lv, 198.

malaja, 198.

malleator, ${ }^{,} \mathrm{liv}, 88$.

malleolus, 88.

malleus, 88.

ninutus, 89.

obesus, 88.

obliquus, lv, 197.

oneratus, 196.

paria, liv, 83.

pilosus, 83.

reponens, 86.

rupicapra, 85 .

scutellaris, 83.

semifascia, lv, 198.

semivitreus, 198

substitutus, liv, 87.

tarandus, 77.

taurus, 85.

terminalis, 85 .

varius, 82.

vicarius, 85 .

Centrotrpus, liv, 87.

assamensis, liv, 88 .

flexuosus, 87.

longicornis,

obesus, 88 .

oneratus, lv, 196.

Cephaloxys, liii, 233.

hebes, $\mathrm{lv}, 192$.

hemelytra, 190.

locusta, liii, 233 : lv, 191.

quadrimacula, 233 : liv, 117.

terpsichore, 233 ; liv, 117.

Cercopide, liv, 5.

Cercopina, liv, 5 . 
Cercopis, liv, 5. abclominalis, lv, 194. amplicollis, liv, 9. basiclava, 17. bispecularis, 10. circumducta, 13. connexa, 11. costalis, 13. decisa, 9. dimidiata, lv, 195. discrepans, 194. dorsalis, liv, 11. dorsimacula, 11, 14. dorsivitta, 15. dubitabilis, 16. ducens, 8. egens, 8. fenestrata, $1 \mathbf{v}, 51$. ferrnginea, liv, 12. fulviceps, lv, 194. fuscipennis, liv, 7. heros, $1 \mathrm{v}, 194$. hilaris, liv, 14. humeralis, 15. latissima, 8 . lydia, 9 . malaya, lv, 193. nebulosa, liv, 21. nigripennis, 7. pallida, 12. pictilis, 12. plana, 7. pudens, 16. pudica, 15: lv, 195. quadrimaculata, liv, 11. ramosa, 11. rugulosa, lv, 193. signifera, liv, 15. stellata, 14. theora, 13. tomentosa, 11, 15 . tricolor, 6. trigyona, 9.

undata, 10.

unifascia, lv, 194.

viridans, liv, 8.

Cerynia, $1 \mathrm{lv}, 64$. maria, $1 \nabla, 64$. rosea, 64 . tenella, 64 .

Chalepus, lv, 48. aconophoroides, 48.

Chalia, lv, 205. aphoenoides, lv, 205.

Chanithus, lv, 26.

Crcada, liii, 229 ; liv, 97 ; lv, 158, 178.

acuta, $\lfloor\mathrm{l}, 185$.

affinis, liii, 211. anæa, 229 ; liv, 116.

apicalis, liii, 231. atomaria, liv, 143.

atra, lv, 184. atrata, 184. aurata, liii, 230 ; lv, 173.

brunnea, liv, 157. candelaria, 128. ciliaris, lv, 144. crocea, liii, 220. crux, liv, 90. delineata, $\mathrm{lv}, 179$. facialis, 186. ferruginea, liii, 230. ferruginea, liv, 98 ; ferrifera, $1 \nabla, 163$. flavida, liii, 227. fuscata, lv, 53. guttularis, liii, 227. hemiptera, 215. hyalina, $1 \mathrm{v}, 51$. immaculata, liii, 231. imperatoria, 229 : lv, 175. indica, 217.

intermedia, 231. 
maculata, 222.

nnaculicollis, 230 ; liv, 157.

mannifera, liii, 223.

marmorata, $1 \nabla, 145$.

mearesiana, liii, 217.

nana, $1 \mathrm{v}, 189$.

nigra, 184.

nobilis, liii, 215.

obtecta, 126.

ocellata, $1 \mathrm{v}, 68$.

octonotata, liii, 221.

operculata, 231.

percheronii, 222.

phonicura, 219.

philamata, 218.

plumosa, Iv, 145.

pulchella, liii, 223.

musilla, 1v, 189.

repanda, 150.

rugipennis, 179.

sanguinea, liii, 218.

sanguinolenta, 218.

semicincta, liv, 117.

speciosa, liii, 217.

spinosa, 227 ; liv, 23, 158; 1v,

166.

splendidula, liii, 220.

striata, liv, $216: 1 \nabla, 181$.

strigosa, $1 \nabla, 180$.

subtincta, liii, 229 : liv, 116.

subvitta, 230 : liv, 117.

subrenosa, $1 \nabla, 179$.

sulphurea, liii, 223.

testacea, 219.

thalassina, 222.

tomentosa, $18,14$.

trabeata, liii, 219.

truncata, 1v, 74.

vaginata, liii, 223.

varia, 1v, 145 .

varians, liii, 226.

versicolor, liv, 18.

70 vicina, liii, 230.

virescens, 223.

virguncula, $1 \nabla, 180$.

xantes, liii, 230: liv, 117; lv,

181.

2-punctata, liv, 111.

Cicadatra, liv, $116 ; 17,158,180$.

quadrimacula, liii, 223: liv,

$117 ; 1 \mathrm{v}, 182$.

striata, liii, 229 ; liv, $116 ; 1 \mathrm{v}$,

181.

xantes, liii, 230 : liv, 117 ; lv, 181.

Cicadide, liii, 210.

Cixina, liv, 97 ; lv, 31.

Crxius, liv, 97; lv, 31.

albistrign, $1 \mathrm{v}, 31$.

bohemani, 33.

caudatus, 32 .

efferatus, 32 .

eminens, 42.

meander, 34 .

pellucidus, 63.

pustulatus, 3 i.

valkeri, 33 .

Clovia, liv, 20.

conifer, liv, 114.

guttifer, 20, 117.

malaya, $\mathrm{lv}, 196$.

multilineata, 196.

nebulosa, liv, 21.

punctum, 115.

quadridens, 117.

Colsa, lv, 196.

costrstriga, $1 v, 196$.

Coccosterphos, liv, 88.

minutus, 89.

Ceridia, liv, 97, 110.

guttivena, lv, 198.

indica, liv, 111.

puuctivena, $1 \nabla, 198$.

Colobesthes, lv, 67. 
albiplana, 71.

conspersa, 72.

falcata, 71.

marginata, 73.

pryer $i, 73$.

Copsrrna, lvi, 86.

maculata, $l \nabla, 86$.

CorethrurA, $1 \nabla, 43$.

fusco-varia, lv, 43.

Cosmopsaltria, liii, 226 ; 17,158 , 178.

abdulla, 226 ; liv, 23, 15E; 1 , 166.

andersoni, lv, 171.

durga, liii, 226 ; 1v, 168.

flavida, liii, 227 ; lv, 170.

obtecta, 226 ; $1 v, 167$.

oopaga, $227 ; 1 \nabla, 169$.

sita, $226 ; 1 v, 168$.

spinosa, 227: liv, 23, 158: 17, 166.

Cosmoscarta, liv, 6.

andamana, liv, 13.

basinotata, 6 .

bimacula, lv, 195.

bispecularis, liv, 10 .

borealis, 12.

decisa, 9 .

dimidiata, lv, 195.

discrepans, 194.

distanti, 195.

dorsalis, liv, 11.

dorsimacula, 11.

ducens, 8.

egens, 8.

exultans, lv, 195.

1 elegantula, liv, 12.

fictilis, 11 .

fulviceps, 194 .

funeralis, 7.

fuscipennis, 7.

heros, lv, 194. lydia, liv, 9 .

malaya, lv, 193.

masoni, liv, 8.

megamera, 7.

moorei, 7.

pallida, 12.

pellucida, $1 \nabla, 195$.

pictilis, liv, 12.

pulchella, lv, 195.

rotundata, 195.

rugulosa, 193.

siamensis, liv, 23 ; lv, 193.

theora, liv, 13.

tricolor, 6 .

trigona, 9.

unifascia, $1 v, 194$.

undata, liv, 10.

viridans, 8.

zonata, 9.

Cromna, 1v, 67.

acutipennis, 72.

angulifera, 70 .

Cryptotympana, liii, 230 ; 1v, 158,

$178,182$.

acuta, lv, 185 .

atrata, liii, 321 ; $1 v, 184$.

bubo, liv, 117 ; 17, 185.

corvus, liii, 23l; liv, 117 ; lv, 185.

facialis, lv, 186.

fumipennis, $l_{v}, 186$.

immaculata, liii, 231 ; $1 \nabla, 183$.

intermedia, liii, 231 ; lv, 184.

invarians, lv, 186.

nigra, Iv, 181.

recta, liii, 230 ; lv, 183.

vicina, liii, 230 ; 1v, 183.

Crnthila, 1v, 201.

ferocula, $1 \nabla, 201$.

Crrene, Iv, 48

fusiformis, 48 .

westwoodi, 49 . 


\section{D.}

Darnina, liv, 90.

Dabrescus, liv, 109. angulatus, 110. nervosopunctatus, 109.

Daradax, lv, 38. fusipennis, 38 .

Dardus, lv, 13.

Delphacina, lv, 35 .

Derbina, $l v, 41$.

Derbe, $1 \nabla, 41$. carnosa, 42. mcesta, 41.

Diceropyga, liii, 226 ; Iv, 166.

Dichoptera, lv, 23. hyalinata, $1 \nabla, 23$.

Dictiophora, $\mathrm{l}, 26$.

Dictropilarina, lv, 22.

Dictrophara, lv, 26. albivitta, 29. despecta, 27. graminea, 27. hyalinata, 23. indiana, 25. inscripta, 27. insculpta, 27. leptorhina, 30 . lineata, 26. nigrimacula, 28. pallida, 27. patruelis, 30 . sauropsis, 30 . sinica, 27. speilinea, 25. walkeri, 29.

Drabescus, liv, 109. angulatus, 110. nerrosopunctatus, 109.

Dundubia, liii, 223 : lv, 157, 178. albigutta, $\mathrm{l}, 171$. chlorogaster, liii, 226. cinctimanus, 228.

doryca, 227.

evanescens, $1 \mathrm{v}, 165$.

fasciceps, 163.

guttigera, 166.

immacula, liii, 225 : liv, 116.

intemerata, liii, 224.

lateralis, 224: liv, 116.

linearis, liii, 228.

maculipes, 224; lv, 161.

mannifera, liii, 223 : liv, 116 ; $\mathrm{v}$, 159.

microdon, liii, 224; lv, 159. nagarasingna, $225 ; \mathrm{lv}, 164$. nicomache, $224 ; 1 v, 160$. nigrimacula, lv, 159.

obtecta, liii, 226. ochracea, lv, 166. radha, liii, 225 ; lv, 163. ramifera, liii, 228. samia, $225: \mathrm{lv}, 162$. saturata, liii, 227. singularis, 225 ; lv, 162.

sobria, lv, 159.

spinosa, liii, 227.

terpsichore, liii, 233 : liv, 117 ; lv, 165.

tigrina, 224; ; lv, 161.

tigroides, lv, 175.

tripurasura, liii, $225 ; \mathrm{l} v, 164$.

urania, liii, 228.

vaginata, 223.

varians, 224 : liv, 116.

vibrans, 224: liv, 116 ; lv. 160.

E.

Elasmoscelis, lv, 42. fusco-fasciata, 42.

Elica, lv, 39. latipennis, 39. Elidiptera, lv, 36. ferruginea, 78. 
fimbria, 80.

indica, 79.

pruinosa, 81 .

smaragdilinea, 37.

Ematria, liii, $229:$ 1v, 158, 178.

ægrota, liii, 229 ; lv, 176.

Epiclines, liv, 96.

hebes, 96.

planata, 96 .

Euacanthus, liv, 100. extremus, 100.

Eupinra, liv, 150. amabilis, 152.

aurantia, 151.

aurora, 152.

discolor, lv, 204.

cornuta, 205.

lectissima, liv, $15 \mathrm{l}$.

submaculata, 151.

walkeri, 152.

Eupilis, $1 \nabla, 45$.

albolineola, 45 .

malaya, 46.

Euria, lv, 38.

lurida, 38.

Eurybrachydina, lv, 12.

Eurybrachys, lv, 12-13.

ceruginosa, lv, 20.

basalis, liv, 155.

bimaculata, lv, 14 .

decora, 20.

fraterna, 14 .

insignis, 19.

lepelletieri, 15.

multicolor, 19.

pulverosa, 17.

punctifera, 16.

reversa, 22.

rubrescens, 17.

rubricincta, 16 .

spinosa, 15.

subfasciata, 17. tomentosa, 14.

tricolor, 21.

venusta, 14.

Euirytera, 1v, 53.

obscura, 53.

F.

Faventia, $1 \nabla, 36$. pustulata, 36.

Fidicina, liii, 231 : lv, 178.

acuta, lv, 185.

atrata, 184.

bicolor, 183.

bubo, liv, 117.

corvus, liii, 231 ; liv, 117.

fumipennis, lv, 186.

immaculata, liii, 231.

intermedia, 231.

invarians, $\mathrm{IV}, 186$.

nivifera, 185.

ochracea, $1 \nabla, 163$.

operculata, liii, 231 ; liv, 117.

recta, liii, 230.

repanda, lv, 150.

vicina, liii, 230.

Flata, liv, 97 ; lv, 67.

acutipennis, $1 \mathrm{v}, 72$.

addita, 74 .

albata, 73 .

angulifera, 70 .

autica, 73.

candelaria, 128.

conspersa, 72.

coromandelica, 74.

distinctissima, 75 .

falcata, 71.

fenestrata, 51 .

ferrugata, 68 .

flaccida, 70.

fuscata, 53 .

guttularis, 75 .

graminea, liv, 27. 
lyyalina, lv, 51.

hyalinata, liv, 23.

indocilis, lv, 70.

inornata, 66 .

intacta, 66 .

intracta, 70.

lactifera, 75 .

lathburii, liv, 30.

lutescens, $1 \nabla, 72$.

lyncea, 83.

maculata, liv, 134.

maria, Iv, 64 .

marginalis, 71 .

marginata, 73.

marginella, 65 .

marginella, 69 .

matutina, 82.

obscura, 52.

ocellata, 68.

pryeri, 73.

punctata, liv, 140.

rectimargo, lv, 76 .

sinensis, 76 .

splendens, 25.

tenella, 64 .

tricolor, 65.

triscripta, 76 .

truncata, 74 .

Fuatina, lv, 63.

Flatoides, lv, 79.

discalis, 52.

dubitans, 78.

emarginatus, 81 .

episcopus, 58.

facialis, 55 .

fenestrata, 51 .

fimbria, 80 .

fumosus, 55 .

guttatus, 58.

hyalina, 51 .

indica, 79.

lignarius, 78. marginalis, 59.

matutina, 82.

minor, 78.

orientis, 51.

perforatus, 55 .

principalis, 80 .

pruinosa, 81.

speculum, 54 .

tenebrosus, 54 .

truncatus, 77.

Flatina, lv, 44.

granulata, 45 .

Frotis, Iv, 13, 22.

pulchra, 22.

Fulgora, liv, 127.

æruginosa, 130.

affinis, 140.

amplectens, 133.

andamanensis, 135 .

brevirostris, 128.

candelaria, 128.

cælestina, 137 : 1v, 200.

cardinalis, 138.

clavata, 130.

coccinea, 138.

connectens, 130.

cultellata, 138.

curtiprora, 136.

cyanirostris, 130 .

decorata, 138.

delessertii, 135.

ducalis, 137 : lv, 199.

festiva, 141.

fulvirostris, 134 .

geminata, 137.

gigantea, 132.

graminea, lv, 27.

guttifera, liv, 138.

guttulata, 136 .

hyalina, lv, 23.

hyalinata, 23.

intricata, liv, 137. 
lathburii, 129.

lauta, 130.

lineata, $\mathrm{lv}, 26$.

maculata, liv, 134.

marginella, $\mathrm{lv}, 65$.

nigrirostris, liv, 30 : lv, 199.

nigromaculata, 133.

nobilis, Iv, 200.

oculata, liv, 131.

pallicla, lv, 26.

philippina, liv, 130.

ponderosa, 131.

punctata, 140.

pyrorkina, 133.

pyrorhyncha, 133.

pyritıochlora, 138.

rajah, 133.

spinolø, 129.

stellata, 137.

sultana, 132.

subocellata, 132.

truncata, lv, 74 .

verhuelli, liv, 132.

virescens, 138.

viridirostris, 129.

Fulgoride, liv, 127.

Folgorina, liv, 127.

\section{G.}

Geava, liii, 221 ; lv, 156.

consobrina, 222 .

consors, 221.

dives, 221 : liv, 116.

festiva, 222 ; lv, 157.

maculata, liv, 222.

octonotata, $221 ; \mathrm{lv}, 156$.

sulphurea, $223 ; 1 \vee, 157$.

sibylla, lv, 156.

Gargara, lv, 198.

malaya, 198.

Gebexwa, liv, 154.

sylvia, 155.
Gedrosia, 1v, 13.

Glossocratus, liv, 102. sulcatus, 103.

Graptotettix, liii, 221 ; lv, 156. guttatus, 221.

H.

Hecalus, liv, 102.

kirschbaumii, 104.

paykulli, 103.

sulcatus, 103.

Helicoptera, lv, 36. smaragdilinea, 37.

HeMiptycha, liv, 90. crux, 90.

HeMispherios, $1 v, 44$. rufo-varius, 44.

Henicopsaltria, lv, 178.

Henicotettix, lv, 178.

Hiracia, lv, 40.

walkeri, 40.

Homalocephala, liv, 141.

festiva, 14l.

Hotinus, liv, 127.

candelarius, 128.

ccelestinus, liv, 137, lv, 200.

clavatus, 130.

ducalis, liv, 137; lv, 199.

delessertii, liv, 135.

fulvirostris, liv, 134.

gemmatus, 137.

guttulatus, 136.

lathlurii, 130.

maculatus, 134.

nigrirostris, $130 ; 1 v, 199$.

oculatus, liv, 132.

ponderosus, 131.

pyrorhynchus, 133.

semiannulus, 138.

spinola, 129.

subocellatus, 132. 
virescens, 138.

virilirostris, 129.

Huecurs, liii, 218; 1v, 153.

crocea, liii, 220.

fumigata, 220.

octonotata, 221.

phænicura, 219.

philæmata, $218 ; 1 \mathrm{v}, 153$.

picta, $1 \nabla, 155$.

sanguinea, liii, 218 ; Iv, 154.

splendidula, 220.

stellata, lv, 154.

testacea, liii, 219.

thoracica, 219. .

trabeata, 219.

transversa, 219 : liv, 116.

Hrgrops, $1 v, 35$.

notivena, 35 .

percheronii, 35 .

HrLICA, liv, 112.

paradoxa, 112.

HrPsaUCiIENia, liv, 80.

balista, 81.

ballista, 81 .

hardwickii, 80 .

uncinata, 80 .

I.

Issina, $1 \mathrm{v}, 43$.

Issus, $1 v, 45$.

apicalis, $\mathrm{lv}, 17$.

malayus, 46.

pectinipennis, 47.

testudinarius, 48.

J.

JASSID $\mathbb{E}, \operatorname{liv}, 91$.

JASSIN , liv, 110.

JASSUS, liv, 97, 110.

alacer, $1 \nabla, 199$.

deplanatus, liv, 111.

sinæ, Iv. 199.

76.
L.

LACUSA, lv, 42.

fusco-fasciata, 42.

Laternaria, liv, 128. candelaria, 128.

LECH EA, $1 \nabla, 66$. dentifrons, 67 .

LEDRA, liv, 92. auditura, 1v, 198.

carinata, liv, 92.

chlorocephala, 107.

P conifera, lv, 198.

culobata, liv, 106.

P cultellifera, Iv, 198.

cultrata, liv, 106.

dilatata, 93.

dorsalis, 94 .

fornicata, 92 .

lineata, 94.

mutica, 92.

nigrilinea, lv, 198.

obligens, liv, 95.

punctata, 94.

punctifera, 95 .

plana, 93.

planata, 96.

quadricarina, lv, 198.

scutellata, lir, 93.

serrulata, 92.

Ledrina, liv, 92.

Ledropsis, liv, 95.

obligens, 95 .

Leptobelus, liv, 81.

auriculatus, liv, 82 .

curvispinus, 82 .

dama, 81.

gazella, 81 .

pallipes, 82 .

paria, 83.

scutellaris, 83 .

varius, 82 . 
Leptocentius, liv, 85.

antilope, 86.

reponens, 86 .

substitutus, 87.

taurus, 85 .

Leptopsaltria, liii, 227; lv, 157,

178.

albigutta, lv, 171.

guttularis, liii, 2:27 : 1v, 170.

tuberosa, 2:27.

Lisors, liv, 141.

westwoodii, 141.

Lopitopina, lv, 4:.

Loxocepiala, lv, 12, 20.

reruginosa, 20.

deeora, 20.

Lrcorma, liv, 148.

delicatula, liv, 150 .

imperialis, 148 .

iole, 150.

punicea, 149.

Lrstra, liv, 142.

aruginos $\alpha, \mathrm{lv}, 20$.

atomaria, liv, 143.

bimaculata, $1 \mathrm{v}, 14$.

cornuta, 205.

dimiliata, liv, 146.

pulchra, lv, 22.

punicea, liv, 149.

spinosu, lv, 15.

tomentosa, 14.

tricolor, liv, 156.

westwoodii, 14:2.

2-muculatu, 1v, 1 .

M.

Miacilerota, liv, 22.

ensifera, liv, 22.

punetato-nervosa, lv, 196.

punctulata, liv, 23.

spangborgi, 2:2.

Machlarotina, liv, 22.
Melampsalta, liii, 225; lv, 15?, 166.

varians, 226.

Membracide, liv, 70.

Mem bracis, liv, 77.

capra, liv, 84 .

flexuosa, 87.

fuscata, 79.

minuta, 89.

planata, 96 .

rupicapra, 85.

tarandus, 77.

taurus, 85.

tricomis, 85.

Messena, lv, 12, 17.

nebulosa, 18.

pulverosa, 17.

Metaurus, lv, 24.

reticulatus, 2.4.

Micreune, lv, 198.

formidanda, 198.

Mindera, lv, 61.

hemerobii, 62 .

Miriza, lv, 61.

sorurcula, 62 .

Mogannia, liii, $232 ; \mathrm{lv}, 189$.

avicula, lv, 190.

chinensis, 193.

conica, liv, 117; Iv, 190.

funebris, liii, 232; lv, 191.

hebes, lv, 192.

ignifera, lv, 190.

illustrata, liii, 232 ; liv, 117 ; lv, 190.

indicans, $232 ; 1 \mathrm{v}, 191$.

lacteipennis, $233 ; 1 \mathrm{v}, 192$.

locusta, 233 ; lv, 191.

nasalis, $1 v, 192$.

obliqua, liii, 232 ; lv, 190.

quallimacula, 233 ; liv, 117.

recta, 232 ; liv, 117; lv, 190.

terpsichore, 233; liv, 117. 
venustissima, $232 ; 1 \mathrm{l}, 190$.

Monecphora, liv, 113. trimacula, 113.

Monopsis, $1 \mathrm{v}, 39$. sinica, 40. viridicans, 39 . ILulvia, Iv, 51.

N.

Nephesa, lv, 82.

marginella, 82. rosea, 82.

Nersia, lv, 26.

Nesis, lv, 12, 21. sanguinipes, 21. tricolor, 21.

Nogodina, lv, 61 .

Nosola, lv, 178.

\section{o.}

Oliarus, lv, 32. bolemani, 33 . walkeri, 33.

Olonia, lv, 13.

Omalocephala, liv, 141. festiva, 141.

Oncotrmpana, lv, 172.

Oxypleura, liii, 214. basialba, liii, 214. bufo, 216.

marmorata, lv, 145. sanguiflua, liii, 216. subrufa, 216.

Oxtrhachis, liv, 76. rudis, 78.

subjecta, 79 . tarandus, 77. unicolor, 78.

P.

Parnisa, 1v, 178.

Paropina, liv, 91.
Penthicus, liv, 145. variegatus, 145.

Penthimia, liv, 112. castanea, 113. compacta, 113. orientalis, 113.

Petalocephala, liv, 106. chlorocephala, 107. expansa, 96. paykulli, 103. planata, 96. wallengrenii, 105.

Phalanomorpha, lv, 79.

Phenice, lv, 41. carnosa, 42. mæsta, 4.1.

Phoronis, lv, 153. nigro-maculata, 153. paulinia, 154.

Phiomia, lv, 64. inornata, 66 . intacta, 66 . marginella, 65 . rubicunda, 65 . tricolor, 65 .

Phyllyphanta, 1v, 67. cereris, 76.

fimbriolata, 69. marginalis, 71.

Phymatostetila, liv, 13. basiclava, 17. binotata, 17. borneensis, lv, 196. circumducta, liv, 13. costalis, 14. dislocata, $1 v, 195$. dorsivitta, liv, 15 . dubitabilis, 16 . hilaris, 14. nympha, lv, 196. pudens, liv, 16. pudica, liv, 15: 1v, 195. 
semele, $l v, 195$.

signifera, liv, 15.

stålii, 13.

stellata, 11, 14.

triseriata, $1 \mathrm{v}, 195$.

Platybracin's, lv, 13.

Platylomia, liii, 226: lv, 166.

Platypleura, liii, 211 : lv, 144.

andamana, liii, 214 ; lv, 146.

arcuata, lv, 145.

assamensis, liii, 212.

basialba, $214 ; 1 v, 146$.

bufo, $216 ; \mathrm{lv}, 1+9$.

calebs, 213 ; lv, 146.

capensis, lv, 145.

capitata, liii, 214, 216.

cervina, $217 ; 1 v, 149$.

ciliaris, $1 \mathrm{v}, 144$.

congrex, liii, 211.

distincta, 213, 233.

fenestrata, lv, 149.

fulvigera, 147.

hilpa, 149.

lirtipennis, 145 .

lyyalinolimbata, 150.

insignis, liii, 216.

interna, 211.

marmorata, lv, 145.

nicobarica, $233 ; \mathrm{lv}, 147$.

nobilis, 215.

ocellata, lv, 145 .

octoguttata, liii, $216 ; \mathrm{lv}, 148$.

phalænoides, liii, 211.

repanda, lv, 150 .

ropstorffii, liii, 214.

semilucida, 215.

sphinx, 213; lv, 145.

straminea, 217.

subrufa, $216 ; \mathrm{lv}, 148$.

Pocharica, lv, 51.

Pochazoiles, lv, 51.

Pochazia, lv, 50. apicalis, $1 \mathrm{v}, 55$.

costimacula, 60 .

fasciata, 53 .

fumata, 53.

gradiens, 60 .

guttifera, 57.

interrupta, 56, 59.

obliqua, 59.

obscura, 52, 53 (?).

ocellus, 55 .

simulans, 56.

sinuata, 53 .

Poecilopsaltria, liii, 211 ; lv, 143.

affinis, liii, 211 ; lv, 143.

capitata, 216.

hilpa, 1v, 149.

octoguttata, liii, 216.

subrufa, 216.

Peciloptera.

addita, $1 v, 74$.

antica, 53, 73.

argiolus, 68.

cereris, 76.

comma, 67.

completa, 82.

coromandelica, 74.

dentifrons, 67.

distinctissima, 75 .

falcata, 71.

fimbriolata, 69.

guttularis, 75.

indocilis, 70.

intracta, 70.

lactifera, 75.

P luteimargo, 83.

lutescens, 72.

maculata, 82.

marginella, 69.

maria, 64.

? niveina, 83.

ocellata, 68.

plana, 74. 
munctifrons, 78.

rectimargo, 76.

sinensis, 76 .

stellaris, 68.

tricolor, 65.

triscripta, 76 .

truncata, 74 .

vidua, 77.

Polvictra, liv, 155.

aphænoides, $1 \nabla, 205$.

basalis, liv, 155.

tricolor, 156.

Polrneura, liii, 211.

ducalis, 211.

Pomronia, liii, 228; lv, 158, 172,

178.

bindusara, liii, 228 ; lv, 173.

expansa, lv, 176.

fusca, 172 .

imperatoria, liii, 229 ; $1 \nabla, 175$.

kama, $228 ; 1 v, 173$.

linearis, $228 ; l v, 175$.

madhava, 229 ; lv, 174.

pallidiventris, lv, 172.

tigroides, liii, $229 ; 1 \nabla, 175$.

urania, 228 ; lv, 172.

Poophilus, liv, 114.

costalis, 114 .

natalensis, 114.

Privesa, lv, 51.

Proarna, lv, 178.

Proconina, liv, 96, 97.

Proconia, liv, 97.

ferruginea, 97.

Prunasis, lv, 178.

Psaltoda, lv, 178.

Pseudophana, lv, 26.

graminea, 27.

hyalinata, 23.

pallida, 27.

patruelis, 30.

splendens; 25.
Ptrelus, liv, 18.

? bipars, lv, 196.

bipunctipennis, liv, 115.

concolor, 114.

conifer, 19, 114.

costalis, 114.

dolosus, 114.

frenulatus, 114 .

guttifer, 20, 117.

? immutatus, lv, 196.

? integratus, 196.

natalensis, liv, 114.

orientalis, lv, 196.

punctum, liv, 19, 115: lv, 196.

quadridens, 19, 117.

rotundatus, 114.

sexvittatus, 19, 115.

simulans, 114.

subfasciatus, 19, 116.

virilicans, 21.

Pucina, lv, 63.

pellucida, 63.

Pruna, lv, 178.

Prrops, liv, 139.

candelaria, 128.

guttulata, 136.

nobilis, $1 v, 200$.

perpusilla, liv, 140.

punctata, 140.

spinole, 129.

virescens, 138.

$\mathrm{R}$.

Ricania, lv, 50.

apicalis, 55 .

costimacula, 60 .

episcopalis, 61 .

episcopus, 58 .

fabricii, 51.

fenestrata, 51 .

fenestrata, 51 .

fumata, 53. 
funiosa, 55 .

fuscata, 5.3 .

gradiens, 60 .

guttata, 58.

guttifera, 57.

hemerobii, 62 .

hyalina, 50, 51 .

interrupta, 56 .

livifrons, 51 .

limitaris, 60 .

maculata, 51 .

malaya, 55 .

margiualis, 59 .

marginella, 69 .

mellerborgi, 52 .

obliqua, 59.

obscura, 53.

obscura, 52.

ocellata, 51, 68 .

ocellus, 55 .

pellucida, 63.

plebeia, 60 .

prominens, 57 .

pulverosa, 61 .

quinquefasciata, 51 .

rosea, 82.

simulans, 56 .

sinuata, 54 .

speculum, 54.

versieolor, 51 .

walkeri, 59.

Ricanina, lv, 49.

Rustia, lv, 177, 178.

pedunculata, 177.

s.

Scamandra, lv, 202.

hecuba, 202.

rosea, 203.

semele, 203.

Scapiula, liv, 90.

? minuta, 89. semiatra, 91.

Scarila, liv, 92.

Scarpanta, lv, 67.

comma, 67.

Scieroptera, liii, 220 ; lv, 155.

crocea, $220 ; \mathrm{lv}, 155$.

fumigata, liii, 220 .

splendidula, liii, 220; lv, 155.

Scolypopa, lv, 50.

Selenocepialdo, liv, 105.

costalis, 108.

cultratus, 106.

egregius, 105.

Seliza, lv, 77.

ferruginea, 78 .

lignaria, 78.

truncata, 77.

vidua, 77.

Selyabria, lv, 178.

Signoretia, liv, 91.

malaya, 91.

Sipylus, lv, 198.

crassulus, 198.

Siva, liv, 107.

costalis, 108.

strigicollis, 108.

Sphenorhina, liv, 114.

approximans, 114 .

braconoides, 114 .

contigua, 114.

intermedia, 114.

proxima, 114.

Sphongophorus, liv, 81.

balista, 81 .

Stagira, lv, 178.

T.

TACUA, liii, 217; lv, 150.

speciosa, 217; lv, 151.

TAPHURA, $1 \nabla, 178$.

Tarundia, $1 \nabla, 50$. 
Tempsa, lv, 45 . malaya, 46 .

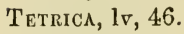
fusca, 47.

Tettigonia, liv, 97. addita, liv, 98. affinis, liii, 211. atrata, $1 \mathrm{v}, 184$. albidicans, 198. apicalis, liv, 98. assamensis, 100. bella, 99 .

brunnea, 157. cardinalis, 101. confinis, 98. duplex, 98. extrema, 100. ferruginea, 98 . festiva, liii, 222. gemina, liv, 98. immaculata, 98, 99. jactans, 111. jocosa, lv, 199. kinbergi, liv, 99. longa, 98. maculata, liii, 222. marmorata, 1v, 145. obscura, liv, 98. obtecta, liii, 226. octoguttata, 216. opponens, liv, 102. pavo, 98. philemata, liii, 218. pusilla, lv, 189. pustulata, 184. quadrilineata, liv, 101. reducta, 98 . repanda, lv, 150. rubromaculata, liv, 101. sanguinolenta, liii, 218. semicircularis, liv, 97. speciosa, liii, 217. 82 spinosa, 227.

splendidula, 220.

suavissima, lv, 199.

suturella, 199.

testacea, liii, 219.

tripars, $1 \nabla, 199$.

unimaculata, liv, 99 .

vaginata, liii, 223.

Thamnotettix, liv, 111.

alacer, 1v, 199.

bipunctata, liv, 111.

malaya, 91.

sinc, $1 \mathrm{v}, 199$.

Thessitus, lv, 12, 18.

insignis, 19.

mortuifolia, 19.

nigro-notatus, 19.

Thomsoniella, liv, 104.

kirschbaumii, $10 \%$.

Trbicen, liii, 231 : 1v, 158, 178, 187.

apicalis, 231 ; liv, 117 ; lv, 188.

auratus, 1v, 178.

aurengzebe, $230 ; 1 \nabla, 187$.

nana, lv, 189.

brunncus, liv, 157.

pusillus, $1 \nabla, 189$.

subvitta, liii, 230 ; liv, 217 ; 1 , 188.

Tituria, liv, 96.

nigromarginata, lv, 198.

planata, liv, 96 .

Tomaspis, liv, 13.

circumducta, 13.

larinia, 17.

pudens, 16.

signifera, 15.

Tosena, liii, 217 ; lv, 151.

albata, $217 ; 1 \mathrm{v}, 152$.

dives, 221.

mearesiana, 217 ; lv, 151.

melanoptera, $217 ; 1 \mathrm{v}, 151$.

splendida, 217; 1v, 152. 
Tricentrus, Iv, 198. fairmairei, 198.

Triopsis, lv, 33.

'Tropiduchina, lv, 37.

Trophucius, lv, 3 . luridus, 38 .

'I'YMPANISTHA, Iv, 17\%.

'I'YMPANOTERPE, lv, 178.
U.

Ugyops, lv, 35. percheronii, 35. Urophora, liv, 116. hardwickii, 116.

$\mathrm{X}$.

Xipilopens, liv, 83. pilosus, 83. 




